Routledge Research in Communication Studies

\title{
GLOBAL PERSPECTIVES ON NGO COMMUNICATION FOR SOCIAL CHANGE
}

Edited by

Giuliana Sorce 


\section{Global Perspectives on NGO Communication for Social Change}

This book examines the central role media and communication play in the activities of non-governmental organizations (NGOs) around the globe, how NGOs communicate with key publics, engage stakeholders, target political actors, enable input from civil society, and create participatory opportunities.

An international lineup of authors first discuss communication practices, strategies, and media uses by NGOs, providing insights into the specifics of NGO programs for social change goals and revealing particular sets of tactics NGOs commonly employ. The book then presents a set of case studies of NGO organizing from all over the world—ranging from Sudan via Brazil to China-to illustrate the particular contexts that make NGO advocacy necessary, while also highlighting successful initiatives to illuminate the important spaces NGOs occupy in civil society.

This comprehensive and wide-ranging exploration of global NGO communication will be of great interest to scholars across communication studies, media studies, public relations, organizational studies, political science, and development studies, while offering accessible pieces for practitioners and organizers.

Giuliana Sorce is a postdoctoral scholar in the Institute of Media Studies at the Eberhard Karls University Tübingen, Germany. She specializes in digital cultures, new media, digital activism, and gender studies. Her research has appeared in journals such as The Communication Review, Journalism Practice, or Feminist Media Studies. 


\section{Routledge Research in Communication Studies}

Interrogating the Communicative Power of Whiteness Edited by Dawn Marie D. McIntosh, Dreama G. Moon, and Thomas K. Nakayama

Media in War and Armed Conflict

The Dynamics of Conflict News Production and Dissemination

Edited by Romy Fröblich

Mediated Intercultural Communication in a Digital Age

Edited by Abmet Atay and Margaret D'Silva

Queer Communication Pedagogy

Edited by Abmet Atay and Sandra L. Pensoneau-Conway

Intercultural Communication, Identity, and Social Movements in the Digital Age

Edited by Ahmet Atay and Margaret D'Silva

Internationalizing the Communication Curriculum

Edited by Paaige K Turner, Soumia Bardhan, Tracey Quigley Holden

and Eddah M. Mutua

Innovation in Advertising and Branding Communication

Edited by Lluís Mas-Manchón

Free Speech and Hate Speech in the United States

The Limits of Toleration

Chris Demaske

Global Perspectives on NGO Communication for Social Change Edited by Giuliana Sorce

For more information about this series, please visit: https://www.routledge. com/Routledge-Research-in-Communication-Studies/book-series/RRCS 


\section{Global Perspectives on NGO Communication for Social Change}

Edited by Giuliana Sorce 
First published 2022

by Routledge

605 Third Avenue, New York, NY 10158

and by Routledge

2 Park Square, Milton Park, Abingdon, Oxon, OX14 4RN

Routledge is an imprint of the Taylor \& Francis Group, an informa business

(C) 2022 selection and editorial matter, Giuliana Sorce; individual chapters, the contributors

The right of Giuliana Sorce to be identified as the author of the editorial material, and of the authors for their individual chapters, has been asserted in accordance with sections 77 and 78 of the Copyright, Designs and Patents Act 1988.

All rights reserved. No part of this book may be reprinted or reproduced or utilised in any form or by any electronic, mechanical, or other means, now known or hereafter invented, including photocopying and recording, or in any information storage or retrieval system, without permission in writing from the publishers.

Trademark notice: Product or corporate names may be trademarks or registered trademarks, and are used only for identification and explanation without intent to infringe.

Library of Congress Cataloging-in-Publication Data

A catalog record for this book has been requested

ISBN: 978-1-032-03713-4 (hbk)

ISBN: 978-1-032-03714-1 (pbk)

ISBN: 978-1-003-18863-6 (ebk)

DOI: $10.4324 / 9781003188636$

Typeset in Sabon

by Apex CoVantage, LLC 


\section{Contents}

List of Illustrations vii

List of Contributors viii

Acknowledgments $\quad \mathrm{xi}$

Foreword xii

BY THOMAS TUFTE

Introduction 1

GIULIANA SORCE

\section{PART I}

$\begin{array}{ll}\text { Communicating for Social Change } & 7\end{array}$

1. NGO-Business Partnerships: Implications for Corporate Social Responsibility and Social Change Communication

VIDHI CHAUDHRI AND JAMES EVERETT HEIN

2. Resource Mobilization Strategies for Social Changes Among Climate Change ENGOs in the United States:

A Text Mining Study

KENNETH C. C. YANG AND YOWEI KANG

3. The Strategy of NGO Journalism in the Fight for Refugee Rights

DELANEY HARNESS

4. Integrating Social Media in NGO Strategic Communication:

Lessons From Dutch NGOs' Communication Practices

DELIA DUMITRICA

5. Narrative Strategies for Animated Development

Communication: Examples from BRAC in Bangladesh 
vi Contents

PART II

Case Studies of Social Change NGOs

6. The Development Workshop Cooperative Giving Voice to the Voiceless: Advocating for Seasonal Agricultural Workers in Turkey

EMEL OZDORA AKSAK AND DANIELA V. DIMITROVA

7. The Government's Needs Versus the Demands of Labor: A Case Study of Organizing by Labor NGOs in China LUWEI ROSE LUQIU

8. Organizational Legitimacy and Communication on Social Networking Sites: A Case Study of Sadagaat and the Hawadith Street Initiative in Sudan

MAHA BASHRI

9. Theorizing Feminist-Democratic Media Activism via NGO Media Activism in South Africa

GIULIANA SORCE

10. Practicing a Politics of Artistic and Communicative Trans Care: Casa Chama and Transvestigender Rights in Brazil ISABEL LÖFGREN

Index 


\section{Illustrations}

\section{Figures}

2.1 Word cloud analysis of ENGOs' resource mobilization strategies $\quad 39$

2.2 The effects of ENGO size on resource mobilization strategies $\quad 40$

4.1 Social media followers across the sample 80

5.1 Collage of images of four scenes from "Rabeya's right to a happy life, free of abuse" 98

5.2 Collage of images of four scenes from “গর্ভবতী ও নতুন মায়েরা থাকুক নিরাপদ" 99

6.1 Seasonal migratory agricultural workers' temporary tent settlement beside the pepper field in Adana Province, Turkey 116

6.2 Situation analysis of migrant workers in seasonal agricultural production in Turkey (2010-2015) 120

9.1 MMA's "Theory of Change" infographic 173

9.2 The cornerstones of feminist-democratic media activism in NGO contexts

\section{Tables}

1.1 Complementary resources and competencies of social change agents

2.1 Climate change ENGOs in the sample 36

3.1 Roles of NGOs in normative journalism traditions 53

4.1 Dutch NGOs interviewed in this project 78

5.1 Common narrative strategies for explainer animations 95

8.1 Sadagaat and HSI Information-Community-Action framework 


\section{Contributors}

\section{Editor biography}

Giuliana Sorce (PhD, Penn State University) is a postdoctoral scholar in the Institute of Media Studies at the Eberhard Karls University Tübingen, Germany. She specializes in digital cultures, new media, digital activism, and gender studies. Her research has appeared in journals such as The Communication Review, Journalism Practice, or Feminist Media Studies. https://orcid.org/0000-0002-3583-9573

\section{Contributor biographies}

Naima Alam (PhD student, Eberhard Karls University Tübingen) is a media scholar in the Centre for Media Competence, Tübingen, Germany. She is currently working on her doctoral thesis focusing on the utilities of explainer animations in education, marketing, and politics. Her research interests include animation in education, health literacy, political activism, diversity communication, development communication, and public relations.

https://orcid.org/0000-0001-6254-6672

Maha Bashri (PhD, University of South Carolina) is Associate Professor of Communication at the United Arab Emirates University. Before joining UAEU, Dr. Bashri was Associate Professor of Communication at Bradley University in Illinois, USA. Her research focuses on media representations of minorities in the United States, diaspora studies, and use of the Information Communication Technologies (ICTs) in non-Western contexts. Currently, she researches the role of media and information literacy on democratic transitions in Africa, especially in relation to networked movements (with particular reference to Sudan) and their communicative sphere.

https://orcid.org/0000-0001-9208-3816

Vidhi Chaudhri (PhD, Purdue University) is Assistant Professor in the Department of Media and Communication at Erasmus University Rotterdam, The Netherlands. Her research focuses on issues of organizational and corporate 
communication, including corporate social responsibility (CSR), reputation management, and implications of social-mediated communication for business and nonprofit firms.

https://orcid.org/0000-0002-1553-9370

Daniela V. Dimitrova (PhD, University of Florida) is Professor in the Greenlee School of Journalism and Communication at Iowa State University and Editor-in-Chief of Journalism and Mass Communication Quarterly. Dimitrova has published widely in the areas of global journalism and political communication in journals such as Communication Research, New Media \& Society and the European Journal of Communication. She is the recipient of multiple awards, including AEJMC Senior Scholar, and grants from the International Research Exchange Board and the Page Center for Integrity in Public Communication.

https://orcid.org/0000-0001-8628-7097

Delia Dumitrica (PhD, University of Calgary) is Associate Professor in the Media and Communication Department at Erasmus University Rotterdam, The Netherlands. Her research focuses on the discursive construction of new media in various fields such as activism, politics, education, and popular culture.

https://orcid.org/0000-0001-6944-6092

James Everett Hein ( $\mathrm{PhD}$, The Ohio State University) is a lecturer in the Department of Sociology at California State University, Los Angeles. His research focuses on environmental movements with publications appearing in Environmental Politics, Social Movement Studies, and elsewhere.

https://orcid.org/0000-0002-5321-899X

Delaney Harness ( $\mathrm{PhD}$ Candidate, University of Texas at Austin) is a researcher in collective action and global governance of human rights and sustainability initiatives. She specializes in issues of visibility and transparency in global governance arrangements. Her work has received awards from associations such as ICA and NCA.

https://orcid.org/0000-0002-0149-8651

Yowei Kang (PhD, University of Texas at El Paso) is Assistant Professor at Bachelor Degree Program in Oceanic Cultural Creative Design Industries, National Taiwan Ocean University, Taiwan. His research interests focus on new media design, digital game research, visual communication, and experiential rhetoric. He has received government funding to support his research in location-based advertising and consumer privacy management strategies. He also won several conference paper awards from AEJMC and ICA over his career.

https://orcid.org/0000-0002-7060-194X 
Isabel Löfgren (PhD, European Graduate School) is Senior Lecturer in Media and Communications Studies at Södertörn University and at the International Masters Program in Art Curating at Stockholm University, Sweden. She received her PhD in Media \& Communications from the Department of Philosophy, Art and Critical Theory (PACT) at the European Graduate School, Switzerland, and is based in Rio de Janeiro, Brazil, and Stockholm, Sweden. Her research interests include emancipatory artistic and curatorial practices, visual and media activism, and network cultures.

https://orcid.org/0000-0002-9707-2857

Luwei Rose Luqiu (PhD, Penn State University) is an assistant professor in the School of Communication at Hong Kong Baptist University, Hong Kong. She researches censorship, propaganda, and social movements in authoritarian regimes. She has been a journalist for 20 years and was a Nieman Fellow at Harvard University. Her research has appeared in journals such as Political Communication and New Media \& Society.

https://orcid.org/0000-0003-3772-9148

Emel Ozdora Aksak (PhD, University of Florida) is an assistant professor in the Department of Communication and Design at Bilkent University, Ankara, Turkey. She worked for the UNICEF Turkey Country Office before transferring to an academic career. Her research interests include organizational communication, public relations, public diplomacy, and refugees and migration.

https://orcid.org/0000-0002-1553-9370

Thomas Tufte (PhD, University of Copenhagen) is Director of Institute for Media and Creative Industries at Loughborough University London and Extraordinary Professor at University of the Free State, South Africa. Tufte has since the early 1990s worked extensively on the role of communication in articulating citizen engagement and social change. His most recent books are Communication and Social Change - A Citizen Perspective (Polity Press, 2017) and Communicating for Change - Concepts to Think With, co-edited with Jo Tacchi (Palgrave, 2020).

https://orcid.org/0000-0003-3253-8481

Kenneth C. C. Yang (PhD, Ohio State University) is Professor in the Department of Communication at the University of Texas, El Paso. His research focuses on new media, consumer behavior, and advertising. He has edited or coedited three books, Asia.com: Asia Encounters the Internet (Routledge, 2003), Multi-Platform Advertising Strategies in the Global Marketplace (IGI Global, 2018), and Cases on Immersive Virtual Reality Techniques (IGI Global, 2019).

https://orcid.org/0000-0002-4176-6219 


\section{Acknowledgments}

The idea for this book emerged after I organized a well-attended panel at the 2019 IAMCR conference in Madrid, where the topic of NGO communication in relation to social change transformation received much interest. I would like to thank Suzanne Richardson for sharing my vision and for the pleasant cooperation on the various stages of this edited collection. I appreciate the valuable input by Laura Portwood-Stacer, who has advised on the final book proposal and reviewer response. I would like to thank my research assistants, past and present (Mona Ulmer, Lea Renz, Tran Trieu, and Annkatrin Voos), who have helped with so many tasks and dedicated countless hours to this book. My grant from the University of Tübingen's Athene Program for Outstanding Female Early Career Researchers has made this assistance possible. Importantly, I would like to thank the many NGOs who are represented in this book for allowing researchers to come observe, learn from you, and reflect your important work. And finally, many thanks to my amazing family for always supporting my academic endeavors. 


\section{Foreword}

This book, Global Perspectives on NGO Communication for Social Change, comes at a most relevant time. It is a time where we really need to explore, analyze, and understand how NGOs work in the realm of communicating for social change.

Across the globe, the space carved out in the past decade by citizens engaged with contemporary development challenges has experienced two contradictory trends. On the one hand, we have seen a massive proliferation of citizen engagement in social movements, and tied to that, a growing engagement by citizens in non-governmental networks and organizations. These engagements range from informal community initiatives, community-based organizations, to large national, international, and transnational NGOs. From the Arab Springs over a decade ago to migrant crises, Black Lives Matter, $\mathrm{MeToo}$, and climate change as more recent examples, citizens have engaged in movements and organizations. Local, national, and transnational efforts to combat human rights violations and social injustice have multiplied and grown. They have emerged and developed in support of strengthening the voice and visibility of marginalized and vulnerable groups across the globe. A lot of their social change efforts have been facilitated, choreographed, and coordinated via online platforms. Increasing citizen engagement, expanded social media opportunities, and a growing body of NGOs and social movements have come to mark our times (Tufte, 2017).

On the other hand, we have also experienced a growing contestation and lots of pushback on this global drive of citizen engagement. Many countries are experiencing a shrinking of space to voice the concerns of their citizens, a weakening of the ability to challenge government policies and practices, the imposition of autocracies with authoritarian policies, a cut in financial support to NGOs, and increasing impediments for international collaboration (Tufte, 2017, pp. 176-179). Adding to the complexities is the growing challenge of misinformation, the infodemic that has grown even stronger during the COVID-19 crisis (WHO, 2020).

In their annual Democracy Report 2021, the research institute "Varieties of Democracy" (V-Dem) at the Department of Political Science at University of Gothenburg has flagged how the repression of civil society is intensifying 
(Alizada et al., 2021). The V-Dem data has registered a substantial deterioration in 50 countries over the past ten years. In the same period, the number of people living in autocracies has increased from $48 \%$ in 2010 to $68 \%$ in 2020 (Alizada et al., 2021, p. 9). Autocratization, V-Dem explains, “typically follows a similar pattern. Ruling governments first attack the media and civil society, and polarize societies by disrespecting opponents and spreading false information, only to then undermine formal institutions" (Alizada et al., 2021, p. 7). A key consequence of such processes is seen in the shrinking of space for citizens to express themselves. As V-Dem data has also identified, the threat to freedom of expression and media has intensified. In 32 countries it is declining substantially, compared to only being in 19 countries just three years earlier.

On top of these challenges, the COVID-19 crisis has made it increasingly visible how difficult NGO communication for social change is today. In a context of growing practices of misinformation, we have seen how urgent but also how difficult it is to tackle the negative consequences of such infodemics globally, not only COVID-19 related but also in general. Infodemics articulate distrust, for example, to communication professionals but also to expert advice and to science (WHO, 2020). Infodemics have sparked popular dissent, confusion, insecurity, and political instability. An example is the widespread social mobilization against district-level government initiatives that was sparked in 2020 by Brazilian President Bolsonaro's rejection of scientific evidence in fighting the COVID-19 epidemic. The infodemic amplified the political tensions and the popular protests.

These are the contexts in which NGOs work and communicate for social change. NGOs thus face numerous barriers in pursuing their causes: operating within complexified dynamics of power struggles; navigating complicated and often very polarized political contexts; having to deal with constrained opportunities for participation; and tackling often multiple challenges for $\mathrm{CBOs}$ and NGO to succeed in their communication for social change. Altogether, the current situation points to a severe time for NGO communication for social change, marked by a crisis in the approach and practice of communication, but also in the fundamental trust between institutions and their constituencies. The result is a situation where the logics and dynamics of NGO communication for social change unfold, globally, within a political economy and within a political reality that seems to reduce the ability not just to represent civil society and its cause-driven initiatives, but also to include these actors in formulating common development agendas for the future.

Ironically, we are experiencing this challenging situation in the year where we also are celebrating the centennial of one of the founding fathers of communication for social change, the Brazilian educationalist and philosopher Paulo Freire. Freire was driven, both in his educational philosophy and in his awareness-raising dialogic communicative practice, by a vision of communication that was empowering. At the Institute for Media and Creative Industries that I direct at Loughborough University London, we organized a 
two-week Centennial Celebration of Paulo Freire in March 2021. We organized two online keynote addresses with Frei Betto and Ailton Krenak, in addition to five global dialogues between ten leading academics and practitioners from an array of universities and organizations. Our organizing principle for this celebration was to take a point of departure in Freire's ontological call. It is a call which is associated with five principles that he presented as the spirit of one of his most well-known works, the Pedagogy of the Oppressed (2001), originally published in 1968.

Freire's five principles are those of humility, empathy, love, hope, and dialogue. They have been developed in different degrees and forms throughout his works, and they have also served as inspiration for many thinkers and practitioners all over the world. In our Centennial Celebrations, we asked if and how these principles can serve as inspiration for creatively devising perspectives and pathways for the development of our societies in the future, also considering the digitality of the future. As such, one could also let this question inspire the reading of this book.

In Loughborough University's Centennial Celebrations, we saw that over the years, Freire's ideas have influenced bottom-up, civil-society-driven development initiatives across the world, in India, the Philippines, South Africa, and Malawi, and across Latin America in particular. Even the research director of BBC Media Action, James Deane, acknowledged how Freire's ideas had been part of his work throughout 40 years of communication practice. Similarly, in a recent special issue of the International Communication Gazette that I coedited with Ana Suzina, we identified how leading Ibero-American thinkers and practitioners-Augusto Boal with his "Theatre of the Oppressed", Boaventura de Sousa Santos with his "Epistemologies of the South", and Juan Diaz Bordenave with his participatory communication-have all been inspired by him. We further analyzed how Freire's vision of development and social change was a constant navigation between a normative vision, grounded in a utopian aspiration for change, and a very systematic and rigorous methodology, his liberating pedagogy (Suzina \& Tufte 2020).

This book, with its cases and examples from across the globe-ranging from Sudan to China, from Turkey to Brazil, from South Africa to the United States, from the Netherlands to Bangladesh-is an exciting investigation into the organization and practice of contemporary NGOs communication for social change. As such, I see this book as an important contribution to the field of action-reflection-action, as Paul Freire would have said, investigating, understanding, and intervening into the world, with communication. We are living in a time where Freire's ontological call, informed by his principles of humility, empathy, love, hope, and dialogue, is more important than ever to have in mind and at hand, when we seek to carve out a citizen-driven NGO communication for social change.

Thomas Tufte London, 11th April 2021 


\section{References}

Alizada, N., Rowan, C., Gastaldi, L., Grahn, S., Hellmeier, S., Kolvani, P., Lachapelle, J., Lührmann, A., Maerz, S. F., \& Pillai, S. (2021). Autocratization turns viral: Democracy report 2021. University of Gothenburg: V-Dem Institute. Retrieved from https://www.v-dem.net/files/25/DR\%202021.pdf

Freire, P. (2001). Pedagogy of the oppressed. London; New York: Penguin.

Suzina, A.C. \& Tufte, T. (2020). Freire's vision of development and social change past experiences, present challenges and perspectives for the future. International Communication Gazette, 82(5), 411-424. https://journals.sagepub.com/doi/full/ $10.1177 / 1748048520943692$

Tufte, T. (2017). Communication and social change. A citizen perspective. Cambridge: Polity. 
$\because$ Taylor \& Francis

Taylor \& Francis Group

http://taylorandfrancis.com 


\title{
Introduction
}

\author{
Giuliana Sorce
}

With respect to social change organizing, non-governmental organizations (NGOs) around the globe do important work on issues such as gender rights, migration, climate change, health, or press freedom, to name a few. Such organizations and their members often fulfill crucial arbitrator roles in democratization efforts, while enabling input from civil society and creating participatory opportunities that could otherwise be circumvented. Indeed, NGOs are understood as "contribut[ing] significantly to the social change process" (Wilkins \& Mody, 2001), a process that aims to empower individuals, demarginalize vulnerable groups, and improve political structures to center the needs of the people.

This book employs the term "social change" as an umbrella concept to capture the humanitarian, democratic, and equity-based efforts across NGO specialization areas. Nodding to Paulo Freire, the term encompasses participatory values and knowledge from below that challenge hegemonic power structures to transform society. His fifth principle, dialogue, is innately linked to communication (Suzina \& Tufte, 2020) and is understood as a key vehicle for social change efforts-one that can drive the "intervention" to pursue "radical changes in society" (Freire, 1998, p. 6). Freire's transformative vision has been called the "blueprint for democratic communication," making it useful to analyze the global NGO scene (Waisbord, 2020, p. 449). Bringing participatory, interventionist, and democratic NGO activity in conversation with social change communication presents a productive merger that drives this book.

NGOs are civil society actors and of particular importance in unstable political contexts or in regions where human rights are violated. While humanitarian organizations such as the Red Cross date back to 1863, the term NGO was established in the context of the United Nations in 1945 (Götz, 2019), referring to those organizations that secured international funding through their association with the UN (Chang, 2005). Defined by their social agenda, NGOs fall into the so-called third sector that exists next to the state and the market (Corry, 2010), contributing significantly to the emergence of civil society across the globe. Lewis (2010) explains that different issues and values shape NGO activity-NGOs in Africa serve

DOI: $10.4324 / 9781003188636-1$ 


\section{Giuliana Sorce}

localized needs in cooperation with hometown associations, while NGOs in Eastern Europe operate more nationally to foster democratization efforts in the greater region. Establishing these organizations, however, does not come without challenges. NGOs are known to be constrained by a lack of funding (Suárez \& Gugerty, 2016), reliance on unspecialized volunteers (Chang, 2005), and potentially conflicting donor relations (Jones, 2017; Reimann, 2006), which can make campaigning for social change particularly difficult.

At the same time, NGOs remain embedded in international politics (Reimann, 2006); indeed, NGO activity and prominence have been historically tied to the agenda of powerful nations-NGOs grew rapidly up to WWI, then declined during WWII, and flourished again in the post-Cold War era (Lewis, 2010). NGOs have been critiqued for a lack of transparency (Nitschke \& Donges, 2018) and accused of facilitating neoliberal goals (Ismail \& Kamat, 2018). The rhetoric of "development," for instance, perpetuates the Global South at the margins, as in the traditional case of transnational Western NGOs setting up localized operations in Asia, Africa, and Latin America. The cultural legacy of these interventions remains ambivalent. At the same time, a focus on Western NGOs in existing media and communication scholarship reinscribes these very power relations and remains a point of contention across the discipline (see also Wilkins, Tufte \& Obregon, 2014).

Media and communication are central in how NGOs engage with key publics, target stakeholders, or address political actors. Although Jones (2017) critiques that international NGOs "increasingly look like media organizations" (p. 177), NGOs across the globe invest in increasing their media repertoires. Social media pages, instant messenger campaigns, or alternative blogs are only a few examples of the various channels NGOs utilize. New networked logics are credited with more exposure for NGOs (Eyal, 2016) and, conversely, NGOs need media to write about them (Moon, 2018). These media reports shape public perceptions of NGOs, the need for their activities, and their standing as legitimate actors (Marberg, van Kranenburg \& Korzilius, 2016).

The particular role of media and communication in NGO organizing has been studied with respect to how NGOs engage public and stakeholders through public relations campaigns (Saxton \& Guo, 2014), in-house journalism (Powers, 2017), or social media communication (Waters \& Jamal, 2011). This viewpoint, however, overemphasizes communication as a mere strategy and reinforces media relations along with news management as the key to NGO success (Moon, 2018). Approaches that systematize NGO strategic communication practices (e.g., Duong, 2017; Lovejoy \& Saxton, 2012) only pay marginal attention to these organizations' cultural impacts while obscuring the very issues at the heart of NGO social change activities. Indeed, an NGO's sociopolitical context, mission, and specific agenda are important factors to consider alongside their media uses. Social change NGOs also invest in finding accessible - at times, unconventional—channels to communicate with the public whose interests they seek to represent. These efforts are often 
characterized by more creative and innovative media practices (Sorce, 2019) and dialogic communication (Bortree \& Seltzer, 2009).

This book seeks to strike a balance between detailing media uses and communication practices for social change organizing while highlighting the particular contexts that make NGO advocacy necessary. It asks two questions: What does social change communication have to offer NGO organizing?; and conversely: What can social change theorizing learn from NGO practice? In line with its transformatory ideals, the chapters also flag why NGO intervention on issues such as the environment, gender equity, refugee rights, or media democratization are considered integral to radical social change. The book features contributions that analyze how social change NGOs communicate with key audiences, including CSR collaborations, website functionalities, in-house journalism, or explainer animations. It also offers case studies that bring contextual depth, painting rich cultural descriptions to immerse the reader into NGO efforts while highlighting the important role media and communication play in social change organizing. By drawing out novel public awareness campaigns in Brazil, successful (digital) participation initiatives in Turkey, or technologically enabled issue mobilization in Sudan, the chapters highlight the important ties between NGO campaigning and societal transformation.

In Part I of this book, authors discuss communication practices, strategies, and media uses by social change NGOs. In Chapter 1, Chaudhri and Hein analyze an important aspect of contemporary NGO relations: NGObusiness partnerships. While paying particular attention to the role of communication in these partnerships, they illustrate how collaborative corporate social responsibility campaigns can facilitate social change around environmental sustainability in Nigeria. They close with a reflection on how initiatives vary in Western versus non-Western contexts and offer a synthesis of critiques on these collaborations. Environmental efforts are also the focus of Chapter 2 on resource mobilization strategies by Yang and Kang. The authors examine how environmental NGOs in the United States communicate on their websites. Their text-mining approach yields what keywords these organizations use and how these enable them to leverage digital media channels to recruit volunteers or popularize their activities. Staying in the US context, Harness in Chapter 3 offers a comparison between two NGOs and their migration rights programs with a focus on NGO journalism. Her analysis yields that digital media platforms and relationships to legacy media organizations are contributing to changing norms in NGO journalism. The public communication practices of NGOs are also the focus of Dumitrica's study (Chapter 4) on social media as an NGO communication strategy in the Netherlands. Drawing on in-depth interviews with ten practitioners, she contends that NGOs do not abandon traditional media in their repertoire, but rather integrate social media into their overall media ecology, arguing that an overemphasis on social media tools overlooks context-specific factors that shape NGO choices in the realm of strategic communication. Alam in Chapter 5 also analyzes a new development in 
NGO media communication with her study of the use of explainer animations by BRAC in Bangladesh. Her analysis of two explainers reveals the promise of this audiovisual medium for NGOs and details narrative strategies for social change issues. Collectively, these essays provide insights into specific communication tactics and media that NGOs commonly employ.

Part II of the book presents a set of case studies of NGO organizing from across the globe. These studies detail particular sociopolitical contexts that make NGO advocacy necessary, while also highlighting successful media and communication-based initiatives to illuminate the important spaces NGOs occupy in civil society worldwide. The Development Workshop Cooperative is the focus of Ozdora Aksak and Dimitrova's Chapter 6 on Turkish advocacy to support a particularly marginalized refugee community, the Syrian Dom. Drawing on interviews, they chart the NGO's strategies in communicating with the Dom agricultural workers and developing targeted advocacy communication materials for various stakeholders. Also engaging with migrant workers, Luqiu's Chapter 7 on the Chinese labor Inno reveals changes in government practices that force NGOs to adopt passive communication practices and careful narrative strategies to avoid shutdown. Her analysis yields that Inno has to negotiate with stakeholders and play by government rules, which also affects how well the NGO can serve the migrant worker population. Bashri's Chapter 8 takes us to Sudan where she examines the social networking patterns of two social change NGOs to show how these organizations operate in an authoritarian regime. She concludes that both NGOs have achieved organizational legitimacy through credible and transparent communication practices on Facebook, a main channel for Sudanese users to engage with social change advocacy. Remaining on the African continent, Sorce's Chapter 9 develops a new theory for understanding media activism that is based in the South African NGO experience. Drawing on ethnographic fieldwork, she theorizes that activism as identity and practice alongside media democratization and a feminist agenda form the cornerstones of the NGO's media activism. Finally, Löfgren illustrates in Chapter 10 how the trans-rights NGO Casa Chama in Brazil employs artsbased interventions as a strategy for advocacy and outreach. The NGO can serve as a role model for other social justice-based collectives with respect to how the transgendering of organizational structures can enable better communication with marginalized communities.

Taken together, the chapters in this book not only cover a wide geographical range but also draw on various methodologies to look at social change organizing in diverse areas, such as gender and LGBTQ rights, environmental efforts, migration and refugee rights, health, or labor rights, to name a few. In doing so, this book fills an important gap in contemporary scholarship on NGOs by providing global perspectives of social change organizations that illuminate both practices and outcomes of media uses and communication initiatives. Importantly, this book reveals what NGO practice has to offer social change theorizing by underscoring the important place these 
organizations occupy in global civil society. With its accessible pieces, this book hopes to engage students and scholars from across the discipline(s), while offering research-based insights for NGO practitioners, grassroots organizers, and activists alike.

\section{References}

Bortree, D. S., \& Seltzer, T. (2009). Dialogic strategies and outcomes: An analysis of environmental advocacy groups' Facebook profiles. Public Relations Review, 35(3), 317-319.

Corry, O. (2010). Defining and theorizing the third sector. In R. Taylor (Ed.)., Third sector research (pp. 11-20). New York: Springer.

Duong, H. T. (2017). Fourth generation NGOs: Communication strategies in social campaigning and resource mobilization. Journal of Nonprofit \& Public Sector Marketing, 29(2), 119-147.

Freire, P (1998). Pedagogy of freedom. Ethics, democracy, and civic courage. New York: Roman and Littlefield.

Ismail, F., \& Kamat, S. (2018). NGOs, social movements and the neoliberal state: Incorporation, reinvention, critique. Critical Sociology, 44(4-5), 569-577.

Lovejoy, K., \& Saxton, G. D. (2012). Information, community, and action: How nonprofit organizations use social media. Journal of Computer-Mediated Communication, 17(3), 337-353.

Moon, R. (2018). Getting into living rooms: NGO media relations work as strategic practice. Journalism, 19(7), 1011-1026.

Reimann, K. D. (2006). A view from the top: International politics, norms and the worldwide growth of NGOs. International Studies Quarterly, 50(1), 45-67.

Saxton, G. D., \& Guo, C. (2014). Online stakeholder targeting and the acquisition of social media capital. International Journal of Nonprofit and Voluntary Sector Marketing, 19(4), 286-300

Sorce, G. (2019). Weaving into the mediascape: An institutional ethnography of NGO media activism in South Africa. Global Media Journal German Edition, 9(1), 1-28.

Suárez, D., \& Gugerty, M. K. (2016). Funding civil society? Bilateral government support for development NGOs. VOLUNTAS: International Journal of Voluntary and Nonprofit Organizations, 27(6), 2617-2640.

Suzina, A. C., \& Tufte, T. (2020). Freire's vision of development and social change: Past experiences, present challenges and perspectives for the future. International Communication Gazette, 82(5), 411-424.

Waisbord, S. (2020). Why Paulo Freire is a threat for right-wing populism: Lessons for communication of hope. International Communication Gazette, 82(5), 440-455.

Waters, R.D., \& Jamal, J.Y. (2011). Tweet, tweet, tweet: A content analysis of nonprofit organizations' Twitter updates. Public Relations Review, 37(3), 321-324.

Wilkins, K. G., \& Mody, B. (2001). Reshaping development communication: Developing communication and communicating development. Communication Theory, 11(4), 385-396.

Wilkins, K. G., Tufte, T., \& Obregon, R. (Eds.). (2014). The handbook of development communication and social change. Malden: Wiley Blackwell. 
$\because$ Taylor \& Francis

Taylor \& Francis Group

http://taylorandfrancis.com 
Part I

\section{Communicating for Social Change}


$\because$ Taylor \& Francis

Taylor \& Francis Group

http://taylorandfrancis.com 


\section{NGO-Business Partnerships Implications for Corporate Social Responsibility and Social Change Communication}

\section{Vidhi Chaudhri and James Everett Hein}

Partnerships between non-governmental organizations (NGOs) and businesses have been defined as cross-sector collaborations or social alliances. Around the world, NGO-business partnerships have grown considerably and, thus, researchers from various disciplines have produced an impressive corpus of scholarship on the topic (Dahan, Doh, \& Teegen, 2010a). The rationales for NGO-business collaborations not only include a focus on mutual benefits, such as the fruitful combination of complementary expertise, but also accommodate more mainstream appeals, such as collaborating for positive societal impact and social change (Selsky \& Parker, 2005; Laasonen, Fougère, \& Kourula, 2012). Giddens et al. (2017) define social change "as the transformation over time of the institutions and culture of a society" (p. 497), and NGOs play a key role in facilitating these transformations. Indeed, multiple actors, including NGOs, governments, and business, are engaged in social change efforts such as working toward more socially responsible oil extraction in Nigeria (Idemudia, 2017). Regardless of whether reactively or proactively prompted, Aguilera et al. (2007) argue that a corporation's responsiveness to shifting societal expectations and the implementation of socially responsible and sustainable goals in business conduct has the potential for positive social change.

In this chapter, we treat business efforts to advance corporate social responsibility (CSR) and sustainability via the formation of NGO-business partnerships as a manifestation of social change efforts. As a case in point, during the early 1990s, the corporate community in the United States was largely unified in resisting regulations on greenhouse gas emissions to combat climate change; however, the international agreement among nations reached with the Kyoto Protocol in December 1997 led some companies to gradually shift toward working to address the climate change problem (Hein \& Jenkins, 2017). One such effort emerged in 2007 between a group of corporate CEOs and environmental NGOs calling itself the US Climate Action Partnership (USCAP), which campaigned for cap-and-trade (Pooley, 2010; Skocpol, 2013; Hein \& Jenkins, 2017).

NGO-business partnerships as a strategy for positive social change has only intensified in the context of CSR and sustainability (e.g., Pedersen \&

DOI: $10.4324 / 9781003188636-3$ 
Pedersen, 2013; Seitanidi \& Crane, 2009; Shumate \& O'Çonnor, 2010). ${ }^{1}$ CSR defies a universal definition. Broadly, it entails "the responsibility of enterprises for their impact on society" (European Commission, 2020). The scope of responsibility can be multidimensional, "integrating social, environmental, ethical, consumer, and human rights concerns into their business strategy and operations" (European Commission, 2020). Being socially responsible is deemed to have mutually reinforcing benefits for organizations (e.g., positive reputation, stakeholder support, employee recruitment, and retention) and society, neatly packaged into the idea of "creating shared value" or CSV (Porter \& Kramer, 2011; for a critique, see Crane, Palazzo, Spence, \& Matten, 2014).

Despite the variations in terminology and scope of activities included in the realm of CSR, its uptake as a management practice in recent decades has been impressive. The professional services firm KPMG's survey of CSR reporting (2017) finds that $93 \%$ of the Global250 and $75 \%$ of the N100 (top 100 companies by revenue) now report on CSR. ${ }^{2}$ Forty percent of the Global250 also discuss the UN sustainable development goals (SDGs) in their corporate responsibility reporting (KPMG, 2018).

Equally impressive has been the focus on NGO-business partners as a mechanism for implementing CSR goals (e.g., Seitanidi \& Crane, 2009). The C\&E Corporate-NGO Partnerships Barometer (2019) attests to this upward trend with $94 \%$ of corporate and $93 \%$ of NGO respondents (in the UK) seeing partnerships as more important over the next three years. Respondents in the Barometer also expect their respective organizations $(67 \%$ corporate versus $83 \% \mathrm{NGO}$ ) to increase investments (e.g., time, money, and resources) to meet cross-sector partnership commitments. The focus on partnerships is further intensified in the SDGs-Goal 17 explicitly urges the importance of global partnerships for sustainable development, and a $50 \%$ increase in partnerships between companies and NGOs is projected in the attainment of the SDGs (Bond, 2019).

This chapter reviews contemporary literature in the fields of communication, public relations, and management on NGO-business partnerships as a social change strategy. Although we concentrate on articles that speak to NGO-business partnerships in the context of CSR, we also include research on cross-sector partnerships that are relevant to our scope. Our goal in this chapter is to outline some old and new conversations surrounding NGObusiness partnerships in the context of CSR and sustainability, focusing more on previously identified gaps in research (e.g., strategic considerations for NGO-business partnerships such as partnership fit) and emergent topics (e.g., communication of partnerships; partnerships in a non-Western context) that collectively further nuance our understandings of such collaborations. For instance, research on the importance of communicating to the public NGO-business partnerships, communicating to mitigate public skepticism, and communicating partnerships on social media are all discussed. We also review topics like NGO-business partnerships in non-Western societies highlighting the importance of institutional considerations that both facilitate 
and constrain collaborations for social change. Additionally, we focus attention on the opportunities and challenges of NGO-business partnerships in addressing sustainability and oil spills in Nigeria.

\section{NGO-Business Partnerships for Social Change}

Propelled by the institutionalization of CSR, businesses are increasingly recognizing NGOs as key stakeholders in cross-sectoral initiatives for social change such as sustainable development. From designing and enforcing sustainability standards, CSR policies, and Codes of Conduct to community involvement initiatives, Nijhof, Bruijn, and Honders (2008) observe that "developing partnerships with societal actors is a sine qua non for companies engaging in CSR initiatives" (p. 153).

An early definition of social partnerships came from Waddock (1988), who emphatically distinguished partnership from corporate philanthropy noting that "throwing money or equipment at problems" does not constitute partnerships. So how are partnerships defined? According to Waddock (1988), social partnerships entail

[a] commitment by a corporation or a group of corporations to work with an organisation from a different economic sector (public or nonprofit). It involves a commitment of resources—-time and effort—by individuals from all partner organisations. These individuals work co-operatively to solve problems that affect them all. The problem can be defined at least in part as a social issue; its solution will benefit all partners. Social partnership addresses issues that extend beyond organisational boundaries and traditional goals and lie within the traditional realm of public policy-that is, in the social arena. It requires active rather than passive involvement from all parties. Participants must make a resource commitment that is more than merely monetary.

Building on Waddell (1999), Jonker and Nijhof (2006) outline the (tangible and intangible) resources and competencies each actor brings to a possible collaboration (see Table 1.1). As different types of agents of social change, both businesses and NGOs benefit considerably by working together, in part because they bring different resources and competencies to their partnerships. NGO-business partnerships are imperative when an NGO lacks the business reputation that a business could utilize in mobilizing change from within an industry when it comes to embracing more ecological practices, for instance. In the case of the Shell partnership with the National Coalition on Gas Flaring and Oil Spills in the Niger Delta (NACGOND), joint investigation visits (JIV) gained credibility from NACGOND's participation due to their community reputation, and Shell passed on specialized industry knowledge in terms of JIV training (Idemudia, 2017). 
Table 1.1 Complementary resources and competencies of social change agents

\begin{tabular}{lll}
\hline & Business & NGOs \\
\hline Resources & - Financial assets & - Inspiration and volunteer assets \\
& - Production systems & - Community networks \\
& - Specialized industry & - Specialized community/issue \\
& - knowledge & knowledge \\
Competencies & - Eusiness reputation & - Community reputation \\
& - Profit generation & - Issue development \\
& - Management skills & - Trust generation \\
& - Business networks & - Support for vulnerable and \\
& - Delivery of goods & - Corginalized issues \\
\hline
\end{tabular}

Source: Adapted from Waddell, 1999; Jonker \& Nijhof, 2006.

Other definitions of social partnerships borrow from the central principles outlined by Waddock (1988) and conceptualize cross-sector partnerships as relationships "formed to explicitly address social issues and causes that actively engage the partners on an ongoing basis" (Selsky \& Parker, 2005, p. $850)$. These associations may be transactional and short-term to integrative to developmental and long-term (p. 851). The Partnering Initiatives (TPI) defines partnerships as "an ongoing working relationship between organisations: aligning their interests, sharing risk and combining their resources and competencies, to maximise the achievement of agreed partnership objectives, while delivering net value to each individual partner" (Bond, 2019, p. 2). Also labeled multi-stakeholder collaboratives, social service partnerships, causebased partnerships, and business-community partnerships, business-NGO collaborations are regarded as vital to creating social change (for a detailed review, see Koschmann, Kuhn, \& Pfarrer, 2012).

Notably, even when researchers acknowledge variations in types of partnership, few, if any, challenge the "dogmatic belief in the necessity of involving NGOs as representatives of society in embedding societal issues in the strategies and day-to-day operations of organisations" (Nijhof et al., 2008, p. 165). Decisions to partner involve a complex interplay of factors-the CSR approach of the business partner (stewardship, business case, or identity orientation), type of NGO, and the mechanisms of engagement. Particularly, when corporations use partnerships as a strategy for risk control, aka "preventing reputation damage by anticipating expectations and claims of external parties" (Nijhof et al., 2008, p. 163), NGOs stand a greater risk to their own legitimacy. By contrast, when organizations take a "stewardship" approach and view themselves as part of an ecosystem of societal actors (along with other stakeholders), the potential for constructive partnerships is higher. In such a configuration, NGOs have access to relevant CSR information and are engaged in monitoring CSR activities and improving CSR policy. 
This assertion reflects in the analytic frames underpinning most scholarship, what Selsky and Parker (2005) label "resource dependence" and "social issues" platforms in which organizations respectively

voluntarily partner primarily to serve their own interests (e.g., acquire needed resources) and secondarily to address a social concern, and [in the latter] the issue is paramount, collaboration is either mandated or voluntary, and the partnership is designed to be issue focused.

Although CSR partnerships are also varied, their rationale arguably reflects what the authors label "societal sector platform" in which partners' values, ways of operating, and motivations are aligned and in which different actors operate in an ecosystem (p. 853). Indeed, research acknowledges the varied motivations for both actors and argues for an alignment of interests if partnerships are to be successful.

\section{NGO-Business Partnerships: Considerations for Success}

A central question in scholarship pertains to the considerations for a successful partnership. Do all partnerships count equally and what are the ingredients for success (see Seitanidi \& Crane, 2009 for a detailed consideration of partnership selection, design, and institutionalization)? Relatedly, what is the role of communication in such collaborations?

Starting with the premise that the creation of (economic, social, and environmental) value is the goal of NGO-business collaboration, and the contention that relationship types, processes, and outcomes need to be better differentiated, Austin and Seitanidi's (2012a and b) Collaborative Value Creation (CVC) framework advances a collaboration continuum going from philanthropy to transformational partnerships. As relationships progress through the different collaboration stages (philanthropy-transactionalintegrative-transformational), so does the potential for synergistic value creation, innovation, and shared interests, being highest at the level of transformational collaborations.

In a similar vein, Jamali, Yianni, and Abdallah (2011) advocate a shift from old/philanthropic approaches (which are discretionary, responsive, peripheral to core business/competence) to new/strategic partnerships (opportunistic, transformative, linked to core purpose). Their study found that, in practice, social partnerships are not inherently innovative relationships. In other words, they did not entail "the generation and implementation of new practices, processes or techniques" (p. 387). The authors note that developing strategic partnerships is critical to accomplish the cocreation of value. Success is contingent on identifying the "nexus of business opportunity and social responsibility" and aligning it to the strategic goals of the partnering organizations (p. 388; also Lodsgård \& Aagaard, 2017). 
This argument is echoed by others as well. In a survey of business organizations, it emerged that the top two factors that contribute the most to both the success and failure of collaborations are the (lack of) alignment in partnership objectives (47\% and $35 \%$, respectively) and (in)effective communication and trust (44\% and 438\%, respectively; De Backer \& Rinaudo, 2019).

\section{Partnership Fit}

Congruence and/or fit between company CSR and cause is deemed a salient factor in predicting partnership outcomes. However, "fit" is not a unitary construct and could imply an alignment of business/category, activity/cause, and familiarity for both NGO and business partners (Kim, Sung, \& Lee, 2012). The effects of the multidimensional notions of perceived fit have differentiated effects on consumer attributions of the partnership. Particularly, familiarity fit of organizations is deemed a critical factor in consumer attributions whereby high-fit alliances are viewed as more public-serving than low-fit alliances (Kim, Sung, \& Lee, 2012). Choi and colleagues (2018) found that aside from company-cause fit, the stage of partnership (i.e., philanthropic or integrative) had a more decisive impact on public perception and attitude. Participants in their study expressed more positive attitudes toward the NGO in the integrative stage even when there was a low fit with the cause. Notably, participants in the low-fit and philanthropic partnership condition reported significantly lower skepticism than participants in the low-fit and integrative partnership condition, suggesting that at a philanthropic level there is less concern about CSR fit.

In addition to company-cause fit, additional factors such as prior corporate reputation and NGO (brand) familiarity could also influence consumer attitudes toward a company's CSR motives and partnership intentions (Rim, Yang, \& Lee, 2016), both of which were confirmed in an experiment setting. From a pragmatic standpoint, these results indicate that partnering with NGOs increases consumers' perceived altruism of CSR motives which in turn enhances identification with the company and consumer support for CSR outcomes. In turn, this implies that NGOs too need to invest in building their brand because partnerships with a familiar or known NGO brand are viewed favorably by business stakeholders.

However, none of these findings can be treated in absolute terms and are dependent on several factors. Kim et al. (2012), for instance, found that alliances between lesser-known companies and well-known NGOs can also backfire, casting suspicion on the company's motives for partnerships. The inconclusive results affirm the need for more research in this arena.

Complicating the picture, Maktoufi, O'Connor, and Shumate (2020) attempt to go beyond the question of whether fit matters in influencing stakeholder perceptions of corporate-nonprofit partnerships to examining what types of messages matter, under what conditions, and to whom. Grounded in their Symbiotic Sustainability Model (Shumate \& O'Connor, 2010) and its premise 
that "the meaning and value of a corporate-nonprofit partnership is communicatively constructed between organizations and stakeholders" (p. 200), the authors find that created fit messaging — even when concise-generates favorable perceptions about the NGO-business partnership.

Consistent with other studies, this result is not applicable in all cases and depends on partnership types and/or the pairing of nonprofit and corporation. In Maktoufi et al.'s (2020) experiment, respondents evaluated the partnership between Philip Morris and The Nature Conservancy on the one hand and Philip Morris and the Boys \& Girls Club on the other and found that in low-fit conditions (such as the latter), stakeholders have higher levels of skepticism. In such instances, created fit messaging is unable to provide a sufficient rationale for the partnerships. The authors suggest that although organizations may choose to support causes they consider important, it needs to fit with stakeholder expectations; if not, organizations are better off not communicating about the partnerships.

More important, this study challenges the dichotomy of high/congruent and low/incongruent fit and proposes to view "fit" "as a continuum that exists at different levels based on the partners" (Maktoufi et al., 2020, p. 201). Therefore, "some partnerships are best described as having an indeterminate level of fit," which the authors explain as follows: "Indeterminate partnerships are unfamiliar and uncertain, rather than congruent or incongruent, thereby making it difficult for stakeholders to assess the compatibility of the two organizations" (p. 202). They further note that given the growing numbers of business-NGO partnerships, it is probably realistic to assume a high number of indeterminate partnerships whereby interested parties are unaware of the NGO and/or business.

\section{Partnership Communication}

An emerging line of enquiry also examines the communication of cross-sector partnerships via traditional and social media. The few empirical studies in this domain view such collaborations as a modern form of CSR practice that can only be successful if the public (especially, consumers) are aware and approving of them. The communication of CSR, more generally, follows a similar line of argumentation whereby communication serves the dual purpose of creating stakeholder awareness and mitigating skepticism toward CSR (Du, Bhattacharya, \& Sen, 2010). Successful partnerships are contingent on communication processes (Shumate \& O'Connor, 2010).

What influences businesses to communicate their strategic CSR partnerships? Yang and Ji (2019) examine this question using legitimacy as an underlying concern whereby communicating cross-sector alliances "serve to legitimize corporations as socially responsible and reputable actors" (p. 2). In this sense, "fit" is interpreted as the congruence between "organizations' legitimacy needs and the symbolic values associated with potential partners" (p. 8). Their investigation of Facebook communication confirms that social 
legitimacy (or the need to be seen as having congruence with stakeholder expectations, norms, and values) and a need for alliance legitimacy (or public approval of partnerships) are the driving factors. The need for social legitimacy was especially pronounced among businesses in controversial industries, which may pose ethical dilemmas for partnering NGOs.

Rohwer and Topić (2019) examine the partnership between British supermarket chain Sainsbury and the anti-poverty NGO Comic Relief to ascertain why some partnerships receive a more positive response than others. They find that although the majority of respondents value such partnerships for their strategic value to society, there are also some who view them only as a form of public relations "to increase their own profit rather than for any moral obligation" (p. 44). Further, their results showed that current customers of Sainsbury knew about their partnership with Comic Relief primarily from in-store promotions, not the corporate website or social media; noncustomers, then, are unlikely to hear about the partnerships and evaluate it positively. Albeit based on a small sample, the study points to an important avenue of research that examines what, how, and why NGO-business partnerships should be communicated for positive impact.

All of these studies emphasize the primacy of communicating altruistic motives to evoke positive stakeholder attributions that can be explained by the greater scrutiny of business relative to NGO communication. Kim, Sung, and Lee (2012) found that although business partnership with a lesserknown NGO that is not a logical fit is viewed suspiciously, the same action by an NGO does not have the same severity/negative consequence. In other words, when NGOs partner with lesser-known or low-fit businesses, they are generally given the benefit of the doubt. That said, frequent NGO communication about partnerships with controversial or stigmatized industry sectors might lend a "halo effect" to the business but jeopardize NGO credibility (Dong \& Rim, 2019; also Yang \& Ji, 2019).

Fewer studies address the topic from an NGO perspective and the ways in which NGOs engaged in CSR partnerships communicate these collaborations. Doing so is argued as a way to understand which CSR issues are privileged (and marginalized) and to appreciate interorganizations and industry-level interdependencies (Shumate, Hsieh, \& O'Connor, 2018). Shumate et al. (2018) contend that by conceptualizing business-NGO partnerships as "representational communication, the primary focus turns from the interworkings of partnerships to the ways that the existence and character of the affiliation is made known to stakeholders" (p. 1342). Their study found that relative to business, (top US-based) NGOs communicate more crosssector partnerships on their websites.

In addition to websites, communication via social media is gaining ground. Examining communication on Twitter, Dong and Zhang (2019) delineate three distinct strategies that NGOs use: self-promotion (primarily focus on causes and activities championed by the NGO; partner roles as supportive to the cause), partner-oriented (recognition of business partner), and 
balanced-interest (prioritize social cause and emphasize the joint role of both business and NGO as partners) - to communicate with their stakeholders. How NGO communication differs from business communication of partnerships and with what consequence is an avenue for further research. From a branding standpoint, Burton et al. (2017) note that cobranded or cocreated messages can benefit both the NGO and the business partner. Indeed, social media are purported to provide the means for "reciprocal promotion," although the limited research on the communication of CSR partnerships suggests that neither actor is effectively leveraging these or traditional communication channels (Burton et al., 2017). Whether the low levels of partnership communication are a missed opportunity or an indication of partnership type (ad hoc and philanthropic as opposed to strategic) and/or the dominance of low-fit partnerships (which tend to be less favorably viewed) merits additional examination. We have summarized some of the elements that contribute to successful NGO-business partnerships as a force for positive social change, with particular attention given to partnership fit and partnership communication. We now turn to an often neglected, yet emerging body of research on non-Western cases of NGO-business partnerships.

\section{Partnerships in Non-Western Country Contexts}

A fast-growing body of scholarship relates to the ground realities of NGObusiness partnerships in non-Western countries. Many of the published articles foreground North American and Eurocentric perspectives that are, arguably, different from the institutional contexts of poverty, conflict, and legal voids that characterize economies in developing countries. How these volatile and less stable institutional environments influence partnership possibilities is worthy of attention (Dahan, Doh, Oetzel, \& Yaziji, 2010b; Jamali et al., 2011). Partnerships in non-Western countries are not completely devoid of Western influence as it is often the Western companies and Western NGOs looking to engage in the Global South, and in cases of domestic companies partnering with domestic NGOs, they often do so confined within the global standards established by transnational institutions dominated by the West. Nevertheless, partnering with NGOs in these nonWestern contexts can allow businesses to develop new business models, and to "create and deliver value ... while minimizing costs and risks" (Dahan et al., 2010b, p. 326). At their end, NGOs can contribute knowledge of the market, ownership, or access to local resources, and the legitimacy with other societal actors. When combined, these complementary resources can yield mutually reinforcing benefits (p. 340).

Conflict settings offer both opportunities and impediments to partnerships (e.g., Kolk \& Lenfant, 2012). On the one hand, they necessitate collaborative arrangements, especially the "knowledge and expertise of NGOs for [business] community engagement endeavors" in which NGOs serve as "buffer for community relations" (p. 500). On the other hand, volatile 
institutional environments require "an even greater degree of understanding of the specific backgrounds of each partner, as well as their perceptions and expectations, than in more stable countries" (p. 479). How do these challenges translate to partnership forms and practices?

\section{Environmental Collaborations in Nigeria and Beyond-An Illustrative Example}

Environmental concerns have been one area in which interests have aligned leading to increasing collaboration between NGOs and business. Scholars have examined many cases of NGO-business engagement on ecological issues (Burchell and Cook, 2013; Lodsgård \& Aagaard, 2017; O'Sullivan \& O'Dwyer, 2015; Paoli et al., 2010; Van Huijstee \& Glasbergen, 2008; Wadham \& Warren, 2013), and while many are optimistic about NGO-business partnerships, they also point to limitations and challenges. In particular, the importance of dialogic communication in such collaborations has been lauded.

In one of the earliest CSR studies on NGO-business collaboration on environmental sustainability, Van Huijstee and Glasbergen (2008) found that dialogues between business and NGOs "improved relationships, increased understanding and trust" (p. 305). Not only does dialogue improve understanding between the two sides, the NGObusiness relationship reduces the potential of the company becoming the target in a negative campaign from an NGO "because the NGO in question will have gained an understanding of the business reality and/ or because the company will have addressed the NGO's concerns sufficiently" (p. 307). In this way, "business becomes an agent for social change in the same way as NGOs, helping to articulate new forms of life and shape alternative approaches" (Wadham \& Warren, 2013, p. 60); NGOs gain as well by having the business reduce its impact on the social problem that concerns the NGO. Furthermore, both sides learn from each other and gain a better understanding of each other's affairs.

The aforementioned benefits are confirmed in various studies in the Nigerian context. For instance, dialogue between Shell and NACGOND, an NGO collective, has been constructive in sparking some social change in the direction of addressing the gas flaring and oil spill problems in the Niger Delta, yet has not completely prevented such environmental destruction from happening (Idemudia, 2017). Formally launched in June 2011, NACGOND is a "coalition of 20 civil society groups that seek to collectively address the issue of environmental degradation in the Niger Delta by advocating for changes in governmental and corporate policies" (p. 269). As opposed to previous ad hoc partnerships, the coalition is seen as a "common engagement platform" that allows members "to collectively leverage their resources and capacities" to advocate for policy change (p. 269). From 
an NGO perspective, the value of dialogue stems from the ability to have "a constructive engagement process that is without rancour and animosity so as to create an environment where we can talk in an open and frank manner ... to collectively improve the environmental situation in the Niger Delta" (Idemudia, 2017, p. 270).

Without undermining the relevance of dialogue, scholars are critical of the push toward consensus in most instances of stakeholder dialogue (Brand, Block \& Verweij, 2019). Brand et al. (2019) contend that an orientation toward consensus in which both sides set aside strategic considerations is problematic for both NGOs (undermining their ability to "voice social criticism") and business as it presents a "tension with the idea of a competitive market in which companies are allowed to exhibit a certain partiality towards their own (commercial) interests" (p. 4). Therefore, the authors propose an alternative understanding of stakeholder dialogue as a form of "agonistic deliberation" in which "conflict and self-interest have a legitimate and, up to a certain point, desirable place" (p. 4). While their proposition is not specific to Nigeria, it offers a nuanced perspective on how NGOs and business may work together, beyond the extremes of consensus and conflict.

Although the Shell-NACGOND partnership has made some gains, the collaboration is not without challenges, including the lack of agreement in monitoring progress to showing actual results and a disconnection in expectations (Idemudia, 2017). As a case in point, a disjuncture in expectations manifests "in the tension between full disclosure as demanded by NACGOND and limited disclosure that the company's policy allows" (p. 274). The volatility of the Niger Delta and its weak institutions further complicate the success of collaborations. For partnerships in conflict zones to be effective, Idemudia (2017) and others (e.g., Kolk \& Lenfant, 2012; 2013) note that "businesses need to align and integrate partnership goals with the firm's overall strategic goals so as to maximize the benefits of the shared value created" (p. 275). Ironically, the Shell-NACGOND collaboration has been touted as a communication success story for CSR, while Amnesty International has called out the hypocrisy, highlighting how, "since 2011, Shell has reported 1,010 spills, with 110,535 barrels or 17.5 million liters lost" in the Niger Delta (Amnesty International, 2018).

Similar challenges are reported in other cases and contexts. O'Sullivan and O'Dwyer (2015) examined the adoption of the Equator Principles (EP) for commercial banks' project finance activities. In 2004, NGOs working under the name of BankTrack were found to have entered into a dialogue with commercial banks "around the lack of accountability mechanisms embedded in the EP [Equator Principles] structure and across EP banks" (p. 43). This consistent dialogue was found to be fruitful, with 60 financial institutions adopting the Equator Principles by the fifth year of the EP in June 2008. Differences between the NGOs and commercial banks remained, yet much cooperation on EP 
was achieved. Nevertheless, the credibility of such commitments has come under criticism more recently because " 13 of the 17 banks that financed the Dakota Access Pipeline were signatories to the Equator Principles. However, despite concerns being raised that the pipeline could threaten the tribe's [Standing Rock Sioux] water supply from Lake Oahe and the Missouri River if a leak occurred, project financing was still given the go-ahead" (Heim, 2019).

As these illustrative examples illuminate, NGO-business relations are dynamic and evolving. NGO-business engagement on sustainability does not conclude at the opening of dialogue but is an ongoing process that should evolve understandings and constantly works to improve limitations on existing agreements for continued productive CSR outcomes in Nigeria and beyond.

Using Austin's (2012a and b) CVC, Kolk and Lenfant (2012) found that most partnerships conform to the conventional donor-recipient model with limited community involvement; few, if any, are transformative partnerships that directly address issues of conflict or have a broader, community-oriented sustainable development, and/or capacity-building focus. However, their study of partnerships in the Democratic Republic of Congo found evidence of a new type of "engagement collaboration" that is situated between philanthropic and transformative forms of partnership:

"Whereas the former is mostly oriented to service delivery, the latter seems particularly relevant in the conflict context as well since it is based on knowledge exchange that furthers companies' awareness of conflictsensitive issues into their operations ... and thus indirectly helps reduce conflict via the organizational route".

Seeking out NGO assistance to "shape and articulate their community relations and CSR strategy" is a resonant theme in other studies as well (e.g., Kolk \& Lenfant, 2013, p. 52; also 2010; Dahan et al., 2010b). Focusing on multinational business-NGO partnerships in central Africa, Kolk and Lenfant (2013) contend that innovative partnerships should take the conflict context into account and aim for community-embedded development goals. However, the authors qualify the types of NGOs that are willing to engage with multinationals noting that service delivery NGOs or NGOs focused on "peace and conflict matters" are more likely to engage in formal partnerships than research and advocacy NGOs (p. 52) possibly for fear of being co-opted.

Other challenges impeding successful partnerships in non-Western country contexts relate to the role of the State and trust among societal actors. In China, NGOs have recently grown independent of government strongholds and are taking on "facilitator" roles such as mediating the relationship 
between business and governmental institutions "or guiding firms' behavior to be more in line with government priorities" and "providing technical knowledge to the firm as well as disseminating information about the partnership and its work through its own network and outreach activities" (Whitehead, 2014, pp. 59-60). By managing different stakeholder relationships in their varied roles, Whitehead (2014) notes that Chinese NGOs are playing an important role in improving CSR practice and affording legitimacy to corporate activities in the region.

When there is a trust deficit, these outcomes may not be possible. Although the issue of trust between NGOs and business is not unique to non-Western countries (Arenas, Lozano, \& Albareda, 2009), it is arguably more problematic in institutionally challenged contexts that demand multi-stakeholder participants to achieve inclusive and equitable development. In the case of India, even when NGOs are acknowledged as the pathway to the community, the mutual suspicion and lack of trust is a detriment to meaningful partnerships (Jayaraman, D'souza \& Ghoshal, 2018; Chaudhri, 2015). In light of the Indian government's controversial CSR Bill (2013) mandating a CSR spend of at least $\%$ of average net profit from the previous three years, businesses are rushing to form alliances. To what extent these will accomplish the value-creation expounded in scholarship remains to be seen (Jayaraman, D'souza \& Ghoshal, 2018).

In addition to the macro considerations (understanding local conditions and support local communities and infrastructures), NGO-business collaborations in developing countries should also consider the "internal" issues (equally relevant in Western countries) of fit between organizational culture of partnering organizations as well as the resource and skill complementarity (Dahan et al., 2010b). While these matters exist for NGO-business engagement in the non-Western world, the partnerships themselves are nevertheless significant. Wadham and Warren (2013), in examining an NGO-business collaboration in Gambia, argue that "partnership emerges as a potential catalyst of social change" (p. 47). Observed changes included business considering their impact on the community. Overall, scholarship on NGO-business partnerships in non-Western societies provides an exciting new direction of understanding the opportunities and impediments in non-Western contexts; progress and uncertainty for partnerships on sustainability; types of NGOs willing to join partnerships; state challenges and issues of trust; and partnership fit. We now discuss the implications of the current literature on NGObusiness partnerships for CSR and social change communication.

\section{Discussion and Implications}

While NGO confrontation and conflict with corporations is often more visible and constitute a critical challenge to business claims of CSR (Hein \& Chaudhri, 2019; Coombs \& Holladay, 2015; Chaudhri \& Kaul, 2017; Davis, Glantz, \& Novak, 2016), NGO-business cooperation is increasingly being embraced to move the business community toward greater corporate 


\section{Vidhi Chaudhri and James Everett Hein}

social responsibility and to more effectively work on solutions like ecological sustainability to solve global problems like climate change.

As this review has shown, communication is key to building trust so that NGOs and businesses can partner together to create positive social change. In demonstrating CSR commitment,

a firm is likely to interact with NGOs, whether on its own initiative, selecting those NGOs for collaboration whose resources and objectives fit well with those of the firm, or by being selected by NGOs as a partner in some form of collaboration.

(den Hond et al., 2015, p. 210)

The interaction is mediated by communication and honest communication between partners and public helps to build trust. And as den Hond et al. (2015) find,

the regular occurrence of personal interactions between firm and NGO managers-frequency of contacts-influences the firms' propensity to collaborate with NGOs, positions individuals within these two organizations as the channels through which dependencies are established, and subsequently manifest in the likelihood of more formal agreements.

(p. 211)

Personal interactions, specifically communication, build that understanding between NGOs and business that enable them to be collaborative agents of change (Van Huijstee \& Glasbergen, 2008; Wadham \& Warren, 2013; Idemudia, 2017). As Idemudia (2017) found, in Nigeria the trust gap between Shell and NACGOND narrowed as a result of them opening up channels of communication so that the problem of oil spills there could be addressed.

Given the grand societal challenges, it is only plausible to expect an upward trend in NGO-business collaborations. Simultaneously, stakeholder pressure is projected to drive partnerships and CSR efforts, more broadly, as evidenced in growing discontent with business practice. Deloitte's 2018 Millennial survey reports lower confidence in business ethics $(48 \%)$ and evidence of business commitment to help society $(47 \%)$, a sizable drop from $65 \%$ and $62 \%$, respectively, in 2017 . Over $75 \%$ view global businesses as pursuing their own agenda and singularly focused on making a profit. The survey also finds a correlation between concern for environmental issues and attitudes toward business-among those with a negative opinion, almost half are also concerned about climate change, suggesting that addressing environmental challenges could potentially alleviate millennials' views of business responsibilities.

Although we cannot paint all businesses with the same brush, there is mounting evidence that trust in business is declining. By contrast, NGOs are seen as the most ethical institution, which, from a partnership (communication) perspective, can be favorable for business. In its 2020 edition, the Edelman Trust Barometer, an annual survey that tracks the state of trust in the four 
main institutions-business, NGOs, government, and media—defined trust as a composite of two attributes: competence (delivering on promises) and ethical behavior (doing the right thing and working to improve society) (Edelman, 2020). Their survey revealed that while none of the four institutions is seen as both competent and ethical, business leads in competence (64\%), whereas NGOs lead on ethical behavior, trailed by business and government.

Does this imply that NGOs can or should have more leverage in making decisions about which businesses they partner with? Under what conditions might this be possible? Whether and in what ways might NGOs be able to use their bargaining power is potentially an avenue for future research. Moreover, as the review suggests, businesses seek to acquire greater legitimacy through CSR partnerships with NGOs, and communication enables this engagement. While these efforts could benefit business efforts to demonstrate responsibility (especially for corporations in controversial sectors), they could pose ethical dilemmas for NGOs. How NGOs navigate these dilemmas in CSR partnerships merits more attention.

The collaborative relationship between businesses and NGOs for more socially responsible corporate behavior has become increasingly prominent, yet the concept of success is contested or at best implicit (see Clarke \& MacDonald, 2019 for reflections on the outcomes of multi-stakeholder cross-sector partnerships albeit not specific to CSR). Arguably, the consensus around type of CSR partnership (the more strategic or transformational, the better) is viewed as a parameter for success (or impact) even in developing economies. A parallel may be drawn with CSR assumptions here. Although strategic CSR or shared value is often propounded as the preferred way to integrate societal and business interests, not all CSR programs need to be strategic or transformational. Rangan, Chase, and Karim (2015) explicitly argue that "neither practical nor logical for all companies to engage in the same types of CSR, since CSR programs are driven by diverse factors" (p. 49). By this logic, some CSR programs may only benefit society (e.g., philanthropy) while others may yield mutual benefits for the firm and society, yet "those outcomes should be a spillover, not their reason for being" (p. 42). Regardless, the authors note, all CSR programs should be aligned with the purpose and values of the business as well as needs of the operating community. Drawing on this parallel, if philanthropic relationships can also yield important outcomes and for who is an important question to consider.

As noted in the introduction, a systematic review of NGO-business CSR partnerships was beyond the scope of the chapter. Equally, it is important to balance the broader implications while distinguishing between the priorities and perspectives of the two societal actors-NGOs and business-engaged in varied forms of collaboration. Even when factors such as strategic fit are identified as critical on both sides, other considerations may be more specific to corporations or NGOs. For example, a study of corporate motivations to partner with NGOs in the Dutch context found that "frequency of contacts" ("routinization of the firm's engagement with NGOs in its practices 


\section{Vidhi Chaudhri and James Everett Hein}

and decision-making") and corporate commitment to CSR were driving factors, whereas trust, prior perception and experience of NGO collaboration, and NGO pressure were the least important considerations from a business standpoint (den Hond, Bakker, \& Doh, 2015, p. 210). At the very least, more research is necessary to make sense of the motivations, processes, practices, and outcomes of partnerships and to examine the contextual determinants that shape these differences.

Another point of reflection pertains to the treatment of NGOs as a homogeneous group (with some exception, see Yaziji \& Doh, 2009; O'Çonnor \& Shumate, 2014; also den Hond, 2010) in scholarship. Conceptually, there is a recognition of NGO types (see Yaziji \& Doh, 2009 and den Hond, 2010), how these classifications translate to partnership relationships on the ground is a nascent area of enquiry. As an example, O'Çonnor and Shumate (2014) categorized NGOs into three distinct groups, each with differential capabilities and partnership potential-prominent (with 4+ business partners; international and local operations), known (foundation-based), and solitary (local, community-based scope of operation) - and concluded that NGOs with multiple corporate partners are distinct from NGOs with single corporate partners. Understanding these differences expands theorizing about NGO characteristics and partnership potential.

Finally, further research should explore the ways by which NGO-business collaborations are communicated. For instance, what is effective communication that could help mitigate some of the public skepticism that Rohwer and Topić (2019) encountered in their research of the Sainsbury-Comic Relief partnership? In that case, online communication was missing from the picture. Likewise, Shumate et al. (2018) find that businesses lag NGOs in communicating their partnerships online. Both, however, could do a better job of jointly promoting their partnerships on social media, as Burton et al. (2017) find.

In sum, the chapter highlights some of the recurring and emerging foci of conversation in the broad realm of NGO-business partnerships for advancing CSR and sustainability as a form of social change. Already, the topic constitutes an impressive and growing body of scholarship that confirms that emerging societal norms and values for cooperative engagement between NGOs and business are propelling the formation of collaborative relationships between the two actors.

\section{Note}

1. Sustainability is generally argued in terms of "sustainable development" introduced in the Brundtland Report as "development that meets the needs of the present without compromising the ability of future generations to meet their own needs." The Dow Jones Sustainability Index refers to corporate sustainability as "a business approach that creates long-term shareholder value by embracing opportunities and managing risks deriving from economic, environmental and social developments." CSR and sustainability are often implicated such as when CSR is defined as "an integral vision of sustainable business practices." 


\section{References}

Aguilera, R. V., Rupp, D. E., Williams, C. A. \& Ganapathi, J. (2007). Putting the s back in corporate social responsibility: A multi-level theory of social change in organizations. Academy of Management Review, 32, 836-863.

Amnesty International. (2018). Niger Delta negligence: How 3500 activists are taking on two oil giants. Retrieved November 30, 2020, from https://www.amnesty. org/en/latest/news/2018/03/Niger-Delta-Oil-Spills-Decoders/

Arenas, D., Lozano, J. M. \& Albareda, L. (2009). The role of NGOs in CSR: Mutual perceptions among stakeholders. Journal of Business Ethics, 88(1), 175-197. https://doi.org/10.1007/s10551-009-0109-x

Austin, J. E. \& Seitanidi, M. M. (2012a). Collaborative value creation: A review of partnering between nonprofits and businesses: Part 1: Value creation spectrum and collaboration stages. Nonprofit and Voluntary Sector Quarterly, 41(6), 726-758.

Austin, J. E. \& Seitanidi, M. M. (2012b). Collaborative value creation: A review of partnering between nonprofits and businesses: Part 2: Partnership processes and outcomes. Nonprofit and Voluntary Sector Quarterly, 41(6), 929-968.

Bond. (2019). Trends in cross-sector partnering for INGOs. Retrieved August 1, 2020, from https://www.bond.org.uk/sites/default/files/resource-documents/bond_-_tpi_ trends_in_cross-sector_partnering_for_ingos.pdf

Brand, T., Blok, V. \& Verweij, M. (2019). Stakeholder dialogue as agonistic deliberation: Exploring the role of conflict and self-interest in business-NGO interaction. Business Ethics Quarterly, 30(1), 3-30. https://doi.org/10.1017/beq.2019.21

Burchell, J. \& Cook, J. (2013). Sleeping with the enemy? Strategic transformation in business-NGO relationships through stakeholder dialogue. Journal of Business Ethics, 113, 505-518.

Burton, S., Soboleva, A., Daellenbach, K., Basil, D. Z., Beckman, T. \& Deshpande, S. (2017). Helping those who help us: Co-branded and co-created Twitter promotion in CSR partnerships. Journal of Brand Management, 24(4), 322-333.

C\&E Corporate-NGO Partnerships Barometer. (2019). Retrieved July 25, 2020, from https://www.candeadvisory.com/sites/candeadvisory.com/files/FINAL_C\% 26E_Corporate-NGO_Partnerships_Barometer_Headlines2019_1.pdf

Chaudhri, V. (2015). The promise and challenge of collaboration for CSR: CorporateNGO engagement. Baltic Rim Economies, 2015(2), 16-17.

Chaudhri, V. \& Kaul, A. (2017). Digital activism: NGOs leveraging social media to influence/challenge corporate social responsibility (CSR). In A. Lindgreen, J. Vanhamme, F. Maon, \& R. Watkins (Eds.), Digital Social Responsibility-A Research Anthology (pp. 277-290). London: Routledge.

Choi, M., Overton, H. \& McKeever, R. (2018). When organizational advocacy and public advocacy intersect in CSR: Examining stage of partnership and activism in CSR partnerships. The Journal of Public Interest Communications, 2(2), 264-264. https://doi.org/10.32473/jpic.v2.i2.p264

Clarke, A. \& MacDonald, A. (2019). Outcomes to partners in multi-stakeholder cross-sector partnerships: A resource-based view. Business \& Society, 58(2), 298332. https://doi.org/10.1177/0007650316660534

Coombs, W. T. \& Holladay, S. J. (2015). How activists shape CSR: Insights from internet contagion and contingency theories. In A. Adi, G. Grigore, \& D. Crowther (Eds.), Corporate social responsibility in the digital age (Developments in corporate governance and responsibility, volume 7, pp. 85-97). Emerald Group Publishing Limited. http://dx.doi.org/10.1108/S2043-052320150000007007 
Crane, A., Palazzo, G., Spence, L. J. \& Matten, D. (2014). Contesting the value of “creating shared value". California Management Review, 56(2), 130-153. https:// doi.org/10.1525/cmr.2014.56.2.130

Dahan, N. M., Doh, J. P., Oetzel, J. \& Yaziji, M. (2010b). Corporate-NGO collaboration: Co-creating new business models for developing markets. Long Range Planning, 43, 326-342. https://doi.org/10.1016/j.lrp.2009.11.003

Dahan, N. M., Doh, J. P., Teegen, H. (2010a). Role of nongovernmental organizations in the business-government-society interface. Business \& Society, 49(1), 20-34.

Davis, C. B., Glantz, M. \& Novak, D. R. (2016): "You can't run your SUV on cute. Let's go!": Internet memes as delegitimizing discourse. Environmental Communication, 10, 62-83. https://doi.org/10.1080/17524032.2014.991411

De Backer, R. \& Rinaudo, E. K. (2019, March 21). Improving the management of complex business partnerships. Retrieved July 25, 2020, from https://www. mckinsey.com/business-functions/strategy-and-corporate-finance/our-insights/ improving-the-management-of-complex-business-partnerships\#

den Hond, F. (2010). Reflections on relationships between NGOs and corporations. Business \& Society, 49(1), 173-178. https://doi.org/10.1177/0007650309348497 den Hond, F., de Bakker, F. G. A. \& Doh, J. (2015). What prompts companies to collaboration with NGOs? Recent evidence from the Netherlands. Business \& Society, 54(2), 187-228. https://doi.org/10.1177/0007650312439549

Deloitte. (2018). Deloitte 2018 millennial survey. Retrieved August 1, 2020, from https://www2.deloitte.com/content/dam/Deloitte/global/Documents/AboutDeloitte/gx-2018-millennial-survey-report.pdf

Dong, C. \& Rim, H. (2019). Exploring nonprofit-business partnerships on Twitter from a network perspective. Public Relations Review, 45(1), 104-118. https://doi. org/10.1016/j.pubrev.2018.11.001

Dong, C. \& Zhang, Y. (2019). NPOs' voice in CSR partnership: An exploratory study using topic modeling. International Journal of Business Communication. https://doi.org/10.1177/2329488418819136

Du, S., Bhattacharya, C. B. \& Sen, S. (2010). Maximizing business returns to corporate social responsibility (CSR): The role of CSR communication. International Journal of Management Reviews, 12(1), 8-19.

Edelman. (2020). Edelman Trust Barometer. Retrieved August 23, 2020, from https://www.edelman.com/trust/2020-trust-barometer

European Commission. (2020). Corporate social responsibility \& responsible business conduct. Retrieved December 28, 2020, from https://ec.europa.eu/growth/ industry/sustainability/corporate-social-responsibility_en

Giddens, A., Duneier, M., Appelbaum, R. P. \& Carr, D. (2017). Essentials of sociology ( $6^{\text {th }}$ ed.). New York: W. W. Norton \& Company.

Heim,S.(2019,Sep 10). Whybanksneed topluggapsinthe EquatorPrinciplestoprevent community conflict. Retrieved August 25, 2020, from https://www.ethicalcorp. $\mathrm{com} /$ why-banks-need-plug-gaps-equator-principles-prevent-community-conflict

Hein, J. E. \& Chaudhri, V. (2019). Delegitimizing the enemy: framing, tactical innovation, and blunders in the battle for the Arctic. Social Movement Studies, 18(2), 171-192. https://doi.org/10.1080/14742837.2018.1555750

Hein, J., \& Jenkins, J.C. (2017). Why does the United States lack a global warming policy? The corporate inner circle versus public interest sector elites. Environmental Politics, 26(1), 97-117.

Idemudia, U. (2017). Environmental business-NGO partnerships in Nigeria: Issues and prospects. Business Strategy and the Environment, 26, 265-276. 
Jamali, D., Yianni, M. \& Abdallah, H. (2011). Strategic partnerships, social capital and innovation: Accounting for social alliance innovation. Business Ethics: A European Review, 20(4), 375-391. https://doi.org/10.1111/j.1467-8608.2011.01621.x

Jayaraman, A., D'souza, V. \& Ghoshal, T. (2018). NGO-business collaboration following the Indian CSR Bill 2013: Trust-building collaborative social sector partnerships. Development in Practice, 28(6), 831-841. https://doi.org/10.1080/0961 4524.2018.1473338

Jonker, J., \& Nijhof, A. (2006). Looking through the eyes of others: Assessing mutual expectations and experiences in order to shape dialogue and collaboration between business and NGOs with respect to CSR. Corporate Governance: An International Review, 14(5), 456-466. https://doi.org/10.1111/j.1467-8683.2006.00518.x

Kolk, A, \& Lenfant F. (2010). MNC reporting on CSR and conflict in Central Africa. Journal of Business Ethics, 93, 241-255.

Kolk, A., \& Lenfant, F. (2012). Business-NGO collaboration in a conflict setting: Partnership activities in the Democratic Republic of Congo. Business \& Society, 51(3), 478-511. https://doi.org/10.1177/0007650312446474

Kolk, A., \& Lenfant, F. (2013). Multinationals, CSR and partnerships in Central African conflict countries. Corporate Social Responsibility and Environmental Management, 20(1), 43-54. https://doi.org/10.1002/csr.1277

Kim, N., Sung, Y., \& Lee, M. (2012). Consumer evaluations of social alliances: The effects of perceived fit between companies and non-profit organizations. Journal of Business Ethics, 109, 163-174. https://doi.org/10.1007/s10551-011-1115-3

Koschmann, M. A., Kuhn, T. R. \& Pfarrer, M. D. (2012). A communicative framework of value in cross-sector partnerships. The Academy of Management Review, 37(3), 332-354. http://dx.doi.org/! 0.5465/amr.2010.0314

KPMG. (2017). KPMG survey of corporate responsibility reporting 2017. Retrieved August 1, 2020, from https://home.kpmg/xx/en/home/insights/2017/10/the-kpmgsurvey-of-corporate-responsibility-reporting-2017.html

KPMG. (2018, Feb). How to report on the SDGs: What good looks like and why it matters. Retrieved August 1, 2020, from https://assets.kpmg/content/dam/kpmg/ xx/pdf/2018/02/how-to-report-on-sdgs.pdf

Laasonen, S., Fougère, M., \& Kourula, A. (2012). Dominant articulations in academic business and society discourse on NGO-business relations: A critical assessment. Journal of Business Ethics, 109(4), 521-545. https://doi.org/10.1007/s10551-011-1143-z

Lodsgård, L. \& Aagaard, A. (2017). Creating value through CSR across company functions and NGO collaborations: A Scandinavian cross-industry case study. Scandinavian Journal of Management, 33, 162-174.

Maktoufi, R., O’Connor, A. \& Shumate, M. (2020). Does the CSR message matter? Untangling the relationship between corporate-nonprofit partnerships, created fit messages, and activist evaluations. Management Communication Quarterly, 34(2), 188-212. https://doi.org/10.1177/0893318919897059

Nijhof, A., Bruijn, T. \& Honders, H. (2008). Partnerships for corporate social responsibility: A review of concepts and strategic options. Management Decision, 46(1), 152-167. https://doi.org/10.1108/00251740810846798

O’Connor, A. \& Shumate, M. (2014). Differences among NGOs in the business NGO cooperative network. Business \& Society, 53(1), 105-133. https://doi.org/ $10.1177 / 0007650311418195$

O'Sullivan, N., \& O’Dwyer, B. (2015). The structuration of issue-based fields: Social accountability, social movements and the Equator Principles issue-based field. Accounting, Organizations and Society, 43, 33-55. 
Paoli, G. D., Yaap, B., Wells, P. L., \& Sileuw, A. (2010). CSR, oil palm and the RSPO: Translating boardroom philosophy into conservation action on the ground. Tropical Conservation Science, 3(4), 438-446.

Pedersen, E. R. G. \& Pedersen, J. T. (2013). Introduction: The rise of business-NGO partnerships. The Journal of Corporate Citizenship, 50, 6-19.

Pooley, E. (2010). The climate war. New York, NY: Hyperion.

Porter, M. E. \& Kramer, M. R. (2011, Jan/Feb). The big idea: Creating shared value. Harvard Business Review, 89(1-2), 62-77.

Rangan, K., Chase, L., \& Karim, S. (2015, Jan/Feb). The truth about CSR. Harvard Business Review, 40-49.

Rim, H., Yang, S. U. \& Lee, J. (2016). Strategic partnerships with nonprofits in corporate social responsibility (CSR): The mediating role of perceived altruism and organizational identification. Journal of Business Research, 69(9), 3213-3219. https://doi.org/10.1016/j.jbusres.2016.02.035

Rohwer, L. \& Topic, M. (2019). The communication of corporate-NGO partnerships: Analysis of Sainsbury's collaboration with Comic Relief. Journal of Brand Management, 26, 35-48. https://doi.org/10.1057/s41262-018-0111-7

Skocpol, T. (2013). Naming the problem. Cambridge, MA: Department of Government, Harvard University.

Selsky, J. W. \& Parker, B. (2005). Cross-sector partnerships to address social issues: Challenges to theory and practice. Journal of Management, 31, 849-873.

Seitanidi, M. M. \& Crane, A. (2009). Implementing CSR through partnerships: Understanding the selection, design and institutionalisation of nonprofit-business partnerships. Journal of Business Ethics, 85, 413-429. https://doi.org/10.1007/ s10551-008-9743-y

Shumate, M. \& O’Connor A. (2010). The symbiotic sustainability model: Conceptualizing NGO-corporate alliance communication. Journal of Communication, 60, 577-609.

Shumate, M., Hsieh, Y. P. \& O’Connor, A. (2018). A nonprofit perspective on business-nonprofit partnerships: Extending the symbiotic sustainability model. Business \& Society, 57, 1337-1373. https://doi.org/10.1177/0007650316645051

Van Huijstee, M. \& Glasbergen, P. (2008). The practice of stakeholder dialogue between multinationals and NGOs. Corporate social responsibility and environmental management, 15(1), 298-310.

Waddell, S. (1999). Collaboration with non profits in civil society: A strategic resources, capabilities and competences perspective. Washington, DC: USAID.

Waddock, S. A. (1988). Building successful social partnerships. Sloan Management Review, 29(4) 17-23.

Wadham, H. \& Warren, R. (2013). Inspiring action, building understanding: How cross-sector partnership engages business in addressing global challenges. Business Ethics: A European Review, 22(1), 47-63.

Whitehead, D. (2014). Chinese NGO-firm partnerships and CSR from an institutional perspective. Journal of Current Chinese Affairs, 43(4), 41-74.

Yang, A. \& Ji, Y. G. (2019). The quest for legitimacy and the communication of strategic cross-sectoral partnership on Facebook: A big data study. Public Relations Review, 45(5), 101839. https://doi.org/10.1016/j.pubrev.2019.101839

Yaziji, M. \& Doh, J. (2009). NGOs and corporations: Conflict and collaboration. Cambridge: Cambridge University Press. 


\title{
2 Resource Mobilization Strategies for Social Changes Among Climate Change ENGOs in the United States
}

\section{A Text Mining Study}

\author{
Kenneth C. C. Yang and Yowei Kang
}

\section{Climate Change ENGOs as Social Change Agents}

Climate change is said to be "the worst environmental problem the world has ever faced," according to Christopher Knittel (2019), Director of MIT Center for Energy and Environmental Policy Research. Concerns about the widespread impacts of climate change on adults between 18 and 34 years of age have been high; $47 \%$ of them believe that climate change will affect their lives (American Psychological Association, 2020). One quarter of them have said climate change has led to extreme weather conditions and natural disasters and $24 \%$ of them express that these problems have affected their communities (American Psychological Association, 2020). A national survey by Yale University has reported that the public consensus on the presence of global warming has reached $67 \%$, and $53 \%$ of these survey participants attribute it to human activities (Marlon, Howe, Mildenberger, Leiserowitz, \& Wang, 2019). Carbon dioxide emissions created by human activities are identified as the main causes of climate change problems (Jang \& Hart, 2015; Xu, Kang, Zhuang, \& Pan, 2010).

Public discourses on climate change usually center on its economic repercussions (The New Climate Economy, 2018, 2016). However, Byrd and DeMates (2014) argue that climate change should be approached as a social problem because its impacts on smaller farmers, rural and urban poor population, the vulnerability of children, women, and the elderly, the need for community to relocate, and unequal adaptability among different demographic segments. The negative effects of climate change affect poor communities and populations most harshly (United Nations Climate Change, 2019a; World Health Organization, 2015). The severity of climate change problems lies in its interwoven relationships with ordinary people's daily life, its global and imminent nature, and the contributing role of developing countries' slack emission standards (Knittel, 2019).

In general, environmental non-government organizations (henceforth, ENGOs) have served as an important function to mobilize social support and to initiate public policymaking procedures through advocacy

DOI: $10.4324 / 9781003188636-4$ 
and lobbying (Mitchell, Mertig, \& Dunlap, 1991). Mitchell et al. (1991) observe that ENGOs contribute to solving environmental issues through three tactical strategies: to educate the public, to take direct actions (such as Greenpeace), or to engage in election campaigns, lobbying, and environmental policy monitoring. ENGOs also have played a key role in the process of social changes by using language to construct discourses of emerging environmental problems to organize social movements to address these impacts (Brulle, 1996). They can also foster community empowerment and literacy programs to adapt and mitigate many negative effects of climate changes (World Health Organization, 2015). ENGOs are involved in global environmental concerns to engage state stakeholders and international organizations to develop social change strategies and functions traditionally done by the states (Finger, 2001).

Similar to other NGOs, climate change ENGOs have served several vital functions to plan and implement social change initiatives such as to educate the stakeholders, garner their support, build institutional capacity, foster dialogue between civil society and ENGOs, and influence government policies (Mubark \& Alam, 2012; Yang \& Kang, 2020). For example, Blue Planet, a local ENGO in Hawaii, focuses on educating future leaders to understand important energy issues to initiate social changes in transforming energy use behaviors at both community and policy levels (Blue Planet, n.d.). Blue Planet also develops creative and innovative environmental communication campaigns to promote green behaviors among various stakeholders (Blue Planet, n.d.). Another ENGO, US Climate Action Network (USCAN), has employed the Internet to establish a virtual network of 185 NGOs on climate change in the United States to mobilize their social change efforts through advocacy and policy development. Environmental Defense Fund has also established an ambition social change plan to reduce carbon emissions globally through nonpartisan policymaking and partnership with other stakeholders (Environmental Defense Fund, n.d.).

Among many social change initiatives implemented by climate change ENGOs, information communication technologies (ICTs) have played an indispensable role (Yang \& Kang, 2020). A recent global survey of technology adoption among NGOs has confirmed this trend to enlist ICTs for social changes (Nonprofit Tech for Good, 2019). According to the Global NGO Technology Report 2019, 97\% of NGOs in North America own their websites that can receive online donation (85\%) (Nonprofit Tech for Good, 2019). Eighty-two percent of them use email to communicate with their supporters and donors (Nonprofit Tech for Good, 2019). Ninety-five percent have a Facebook page, while 56\% use Instagram, and $64 \%$ use Twitter (Nonprofit Tech for Good, 2019). Technology has become an integral tool of NGO's resource mobilization strategies to build their own organizational capacity to implement their social change programs in terms of educating the public and lobbying for pro-climate change policy. 


\section{Objectives of This Study}

Despite the significance of the ICT-enabled resource mobilization strategies to build ENGOs' capacity, research has been scant to provide a large-scale descriptive analysis of how climate change ENGOs in the United States have utilized their official organizational website to integrate other social and mobile platforms into this commonly accessible technology. For example, the $1 \%$ for The Planet Inc. website includes mobile and Podcast platforms, in addition of ample textual webpages about this organization.

The objectives of this study are to examine their current website applications to accomplish many social change missions in mitigating climate change risks. We use a text mining approach of ENGO's official websites to understand their approaches, strategies, and visions related to these technology-enabled capacity-building activities. On the basis of these findings of extracted keywords and key phrases, we discuss ICT-enabled resource mobilization strategies among 44 climate change ENGOs in the United States to implement their social change efforts. Specifically, this study aims to provide answers to the following research questions:

RQ1: How will recurrent keywords and key phrases extracted from climate change organization websites describe the approaches, strategies, and visions related to ENGOs' ICT-enabled resource mobilization strategies to support various capacity-building activities?

RQ2: What can ENGO practitioners learn from the relationship between organizational characteristics and different ICT-enabled resource mobilization strategies when implementing their own communication tactics?

\section{Literature Review}

\section{Resource Mobilization Among Climate Change ENGOs in the United States}

The mobilization of various resources has been the center of studying a social organization's strategies and tactics through interactions and networking with other groups to garner social support (McCarthy \& Zald, 1977). Theorists have later introduced Resource Partition Theory (henceforth RPT) to account for how interorganization competition could lead an organization to become specialized in their strategies and tactics to ensure its survival (Soule \& King, 2008). In the past, ENGOs' strategies to mobilize limited amount of resources through grant proposal writing and donor identification have been traditionally critical to their success and survival (ACDEF, n.d.). Nowadays, climate change ENGOs' abilities to mobilize "like-minded issue public" through Internet-mediated advocacy are also essential to their success (Hestres, 2014). Climate change ENGOs serve as an important social 


\section{Kenneth C. C. Yang and Yowei Kang}

change agent by framing climate change debates and shift public attitudes to be more pro-climate change agendas (Hestres, 2014).

According to De Vita, Fleming, and Twombly (2001), resources can influence ENGO's abilities to accomplish its organizational missions, recruit competent managers, and communicate its message to the local community to develop adaptation and mitigation plans to address many climate change risks. Resources are also essential to help ENGOs to empower local communities, develop environmental awareness programs, and educate future community leaders to ensure social changes at both local and national levels (Ogunbode Ogungbile, Odekunle, \& Asifat, 2019; World Health Organization, 2015). ENGOs' strategies to mobilize a variety of resources have been an important component of their capacity-building efforts (Yang \& Kang, 2020).

According to the Paris Agreement, capacity-building is "a fundamental precondition to foster enhanced and sustained coordination and coherence to enable governments and stakeholders to cut emissions and adapt to climate change" (United Nations Climate Change, 2019b, n.p.). The study of the capacity-building processes has often involved the examination of how ENGOs develop and mobilize financial, technological, and social capital resources, foster specialized skills among their employers, implement management systems within the organization, and encourage the success of organizations' missions and achievable development (Büscher, 2014; De Vita et al., 2001; Li \& Guo, 2015; NPO Information Consultation Center, 2003). Like many NGOs, ENGOs also face dilemmas related to the lack of funding and infinite needs to chase resources to complete their missions (Viravaidya \& Hayssen, 2001).

Climate change problems can be managed more effectively if ENGOs can build their capacities to mitigate these risks (Global Commission on Adaptation, 2019). Without sufficient resources and their effective management, climate change ENGOs are less likely to succeed in their social change goals. Therefore, as a specific sub group of ENGOs, it is important to examine climate change organizations' resource mobilization strategies, as a vital capacity-building component, to contribute to their social change objectives by raising awareness and building knowledge among the stakeholders.

Considering the financial downturns due to the global spread of the coronavirus, the development of comprehensive financial management and the improvement of fundraising capabilities (De Vita et al., 2001) are the two most critical capacity-building functions ENGOs will be pursuing. In addition to building an ENGO's financial resources, the acquisition of information technologies, as part of the ENGO's physical resources, has been identified as an essential capacity-building objective (De Vita et al., 2001).

However, an ENGO's capacity should not be limited to merely financial resources, this study intends to examine how climate change ENGOs in the United States have employed many emerging digital platforms to mobilize resources to accomplish their social change objectives at an individual, 
community, and national levels. According to Nonprofit Tech for Good (2019), many NGOs in the United States have employed a variety of ICTs to assist their acquisition of financial resources. For example, 34\% of them use mobile card readers, $24 \%$ use crowdfunding, $13 \%$ use test-to-give, while $1 \%$ use mobile money. These financial resources allow NGOs to employ competent staff members, recruit volunteers, and pay for board members as part of their human resources.

\section{ICTs and Capacity-Building for Climate Change NGOs in the United States}

ICTs such as email, web, social media, and mobile technology have become an important component of NGO's technology mobilization as part of their capacity-building strategies. ICTs are vital to confronting climate change problems (Ban, K.M., cited in Dickerson, Torres, Canet, Smiciklas, Faulkner, Bueti, \& Vassiliev, 2011). For climate change ENGOs, ICTs are critical to achieve adaptation, capacity-building, mitigation, and technology transfer to minimize climate change risks through fast and low-cost information sharing and dissemination (Faulkner, Ospina, Dickerson, \& Bueti, 2013). Furthermore, over $80 \%$ of NGOs in this survey have identified several most effective ICTs for fundraising (such as website, email updates, social media, and video) to implement climate change adaption and mitigation strategies (Nonprofit Tech for Good, 2019).

Among many ICT applications, organization websites are the most popular and commonly used platform. Ninety-seven percent of NGOs in the United States and Canada have set up their organizational websites (Nonprofit Tech for Good, 2019) to communicate with local communities and populations to increase their knowledge about climate change problems. Often equipped with advanced mobile compatibility, event registration, online stores for e-commerce, and live chat functions (Nonprofit Tech for Good, 2019), ENGOs' official websites can function as a low-cost and easyto-implement alternative (to traditional modes of communication) to enable NGOs to facilitate their ability to collaborate and communicate with people locally or around the world (De Vita et al., 2001). Nonprofit Tech for Good (2019) has reported that $82 \%$ of the Canadian and US NGOs send email updates to their supporters either daily, monthly, or quarterly, so that they can be informed of any latest development of technology-enabled capacitybuilding for ENGOs.

Website is the earliest ICT platform when the Internet was first introduced in the 1990s. The utilization of these ICTs has been examined whether NGOs have adapted to the challenges and opportunities at the management levels (Laporte, Kelly, \& Agbabiaka, 2018; Mogus \& Levinh-Coon, 2018). Scholars have also studied their roles in mobilizing resources for NGOs $(\mathrm{Li}$, Tang, \& Lo, 2018; Nonprofit Tech for Good, 2019; Saxton \& Guo, 2012, 


\section{Kenneth C. C. Yang and Yowei Kang}

2014; Yang \& Kang, 2020) and their roles in adapting and mitigating climate change risks (Faulkner et al., 2013). Recent advances in social networking technologies have prompted scholars to examine how social media can also help NGOs' resource mobilization strategies. For example, Saxton and Guo (2014) have studied the role of Twitter in targeting core stakeholders among 117 community foundations in the United States and they have thoroughly examined the function of this popular social media platform in terms of their resource mobilize capabilities. Their study has analyzed the Twitter-based communicative and advocacy functions as reflected in social media messages (Saxton \& Guo, 2014). Other scholars have also focused on the applications of these new media platforms in enhancing NGO's organizational capacities in terms of fostering specialized skills of staff members, instituting management systems, setting up learning networks, and encouraging the fulfillment of organization's missions and viable development (Büscher, 2014; Li \& Guo, 2015; NPO Information Consultation Center, 2003). Because ENGOs constitute an important part of an emerging civil society to initiate social changes, this study is important in understanding their resource mobilization strategies as an important part of ENGO's capacity-building efforts among climate change ENGOs in the United States (Li et al., 2018; Saxton \& Guo, 2014).

Some of the emerging research areas of ENGO's digital technology applications have begun to address their benefits of mobilizing different types of resources (Li et al., 2018), garnering social media capital resources (Saxton \& Guo, 2014), or obtaining actual financial resources such as donations (Saxton \& Guo, 2014). In a recently published survey report of global ENGOs, $85 \%$ of NGOs in the United States and Canada accept online donations through their websites through credit cards, PayPal, direct debit, digital wallet, or cryptocurrency (Nonprofit Tech for Good, 2019). Yang and Kang (2020) have developed an ICT-enabled capacity-building framework to account for the impacts of mobile social media platforms on ENGO's resource mobilization strategies. According to their model, it can be argued that technological characteristics of emerging ICT platforms contribute to the capacity-building of climate change ENGOs in the areas of vision and mission, leadership, resource mobilization, outreach programs, and product and service offerings (Yang \& Kang, 2020).

\section{Research Method}

Previous research that examined how ENGOs built their organizational capacities has mainly employed a case study method to describe and analyze their needs, strategies, and community impacts (De Vita et al., 2011; McPhee \& Bare, 2011). For example, McPhee and Bare's (2011) descriptive case study reported the collaboration among Knight Foundation, CNP, and HIRI to help improve local communities by identifying knowledge gap and transforming knowledge into practice. However, a single case study of ENGOs in general or climate change ENGOs in specific does not provide 
an investigation of cross-organizational capacity-building strategies by these organizations. Nonprofit organization scholars such as Saxton and Guo (2014) have examined the websites of 677 community foundations from the Council on Foundations website to study the role of ICTs in ENGOs' capacity-building. This study advances their approaches by employing a large-scale text mining study of climate change ENGOs' website to examine their capacity-building by focusing on the role of ICTs in resource mobilization, paying close attention to the most prominent ICT-enabled capacitybuilding strategies on their official websites.

This study examines the role of ICTs in climate change ENGO's resource mobilization strategies to support their capacity-building endeavors to support their volunteer recruitment, community involvement, and donations. We also describe repeated keywords as reflected in these ENGOs' official websites by a computational data processing (Hase, Engelke, \& Kieslich, 2020). Computational data processing techniques enable researchers to analyze a huge quantity of data systematically, without prejudices, without coders' mistakes, and more impartially (Diakopoulos, Zhang, \& Salway 2013; Kang $\&$ Yang, 2018). Among numerous computational data processing methods, the text mining techniques have been most pertinent to this study. Text mining research has often examined structured or unstructured data, ranging from emails, full texts, and websites, to extract the key semantic features (Usai, Pironti, Mital, \& Mejri, 2018). We extract meaningful, repetitive, and useful semantic keywords from the unstructured textual data (He, Zha, \& $\mathrm{Li}, 2013$ ) among 44 climate change ENGOs in the United States. These text mining techniques have increasingly been adopted by social science scholars (Diakopoulos et al., 2013; Kang \& Yang, 2018; Teso, Olmedilla, MartinezTorres \& Toral, 2018) when handling a large quantity of textual data.

This study employs QDA Miner and its add-on programs, WordStat and SIMSTAT (Silver \& Lewins, 2014). As a commercial and proprietary software, package QDA Miner "offers good coding, mining, data organization, retrieval, and interrogation functions" (Silver \& Lewins, 2014, n.p.). The affiliated data analysis program, WordStat program, also provides content analysis functions to recognize keywords, key phrases, and topics and to produce graphs such as WordCloud, Key Phrase Extraction, Model Extraction, or Link Analysis to visualize results of the text mining analyses (Silver \& Lewins, 2014).

We have selected 44 ENGOs' websites from GuideStar's Directory of Charities and Nonprofit Organizations ${ }^{1}$ and Google searches (using "climate change" and "non-government organizations" as the keywords). These organizations have included ENGOs specialized in clean air, clean water, recycling, and energy. Local, national, and international ENGOs have been included. Some ENGO examples have included 1\% for the Planet, Inc., One Green Planet, Clean Air Carolina, Clean Water Project, Inc., Climatepath Ecological Fund, Recycle Eureka, 350.org, Sierra Club Foundation, Greenpeace, EarthJustice, Nature Conservancy, etc. (refer to Table 2.1). 


\section{Kenneth C. C. Yang and Yowei Kang}

Table 2.1 Climate change ENGOs in the sample

\begin{tabular}{|c|c|}
\hline Names of ENGOs & Website Links \\
\hline $1 \%$ For the Planet Inc. & www.onepercentfortheplanet.org \\
\hline One Green Planet & www.onegreenplanet.org \\
\hline 3 Rivers Wet Weather Inc. & www.3riverswetweather.org \\
\hline American Clean Water Project Inc. & awsproject.org \\
\hline $\begin{array}{l}\text { Center for Climate and Energy } \\
\text { Solutions }\end{array}$ & www.c2es.org \\
\hline Clean Air Carolina & cleanaircarolina.org \\
\hline $\begin{array}{l}\text { Clean Air Coalition of Western New } \\
\text { York Inc. }\end{array}$ & www.cacwny.org \\
\hline Clean Air Conservancy & www.educationfricamwomen.org \\
\hline Clean Air Force of Central Texas & cleanairforce.org \\
\hline Clean Air Northwest & nwcleanairwa.gov \\
\hline Clean Air Watch & sourcewatch.org \\
\hline Clean Jordan Lake & www.cleanjordanlake.org \\
\hline Clean Ocean Action Inc. & cleanoceanaction.org \\
\hline Clean Our Parks and Streams & $\begin{array}{l}\text { https://www.guidestar.org/ } \\
\text { profile/93-1119573 }\end{array}$ \\
\hline Clean Sound Cooperative Inc. & $\begin{array}{l}\text { https://www.guidestar.org/ } \\
\text { profile/91-1496815 }\end{array}$ \\
\hline Clean the Bay Inc. & $\begin{array}{l}\text { https://www.guidestar.org/ } \\
\text { profile/65-1257789 }\end{array}$ \\
\hline Clean the World Foundation Inc. & cleantheworld.org \\
\hline Clean Water Councils, Inc. & $\begin{array}{l}\text { https://www.guidestar.org/ } \\
\text { profile/57-1013037 }\end{array}$ \\
\hline Clean Water Project Inc. & thewaterproject.org \\
\hline Clear the Air Foundation & www.cleartheairfoundation.org \\
\hline Climatepath Ecologic Fund & www.climatepath.org \\
\hline Climatesmart Charity & $\begin{array}{l}\text { https://www.guidestar.org/ } \\
\text { profile/56-2661243 }\end{array}$ \\
\hline Coalition for a Clean Minnesota River & www.ccmnriver.org \\
\hline Coalition for Clean Air & www.ccair.org \\
\hline Project Clean Air & projectcleanair.us \\
\hline Recycle Eureka Inc. & eurekarecycling.org \\
\hline Recycle Hawaii & recyclehawaii.org \\
\hline Recycle Livingston Inc. & www.recyclelivingston.org \\
\hline Recycle Montana Inc. & recyclemontana.org \\
\hline Recycle of Mecosta County Inc. & recyclemecosta.org \\
\hline 350.org & http://350.org/ \\
\hline Environmental Defense Fund & https://www.edf.org/ \\
\hline Sierra Club Foundation & http://www.sierraclubfoundation.org/ \\
\hline Union of Concerned Scientists & http://www.ucsusa.org/ \\
\hline Greenpeace & http://www.greenpeace.org/usa/en/ \\
\hline Wood's Hole Oceanographic Institute & http://www.whoi.edu/ \\
\hline EarthJustice & http://earthjustice.org/ \\
\hline
\end{tabular}




\begin{tabular}{ll}
\hline Names of ENGOs & Website Links \\
\hline Center for Climate and Energy & https://www.c2es.org/ \\
$\quad$ Solutions & http://thesolutionsproject.org/ \\
The Solutions Project & http://www.nature.org/ \\
Nature Conservancy & https://www.nrdc.org/ \\
National Resources Defense Council &
\end{tabular}

We compiled the database by retrieving webpage contents from these 44 climate change ENGOs. We particularly focus on textual contents related to their core capacity-building strategies, such as their visions and missions, financial, technological, and human resources, and networking/outreaching strategies (Yang \& Kang, 2020). These textual contents are created by these ENGOs as part of their websites; visual infographics and links to external government or press documents will not be included in our database. Website contents from these ENGOs were examined multiple times to reach consensus between two researchers before placing them into different capacity-building categories in a QDA Miner's project file. We also follow the data cleaning procedures in excluding unimportant words or characters, lowercase conversion, stop word removal, text segmentation, and word stemming (Kobayashi, Mol, Berkers, Kismihók, \& Hartog, 2018).

The bag-of-words technique in most text mining software packages has allowed researchers to group text in words by treating "each word as a feature and counting the frequency of occurrence of the word and ignoring the co-occurrence" (Usai et al., 2018, p. 1473). However, the bag-of-words approach has been criticized for not being able to identify association, cooccurrence, and order of occurrence among extracted words (Schumaker, Zhang, Huang, \& Chen, 2012; Usai et al., 2018).

\section{Findings}

To answer our first research question on prominent keywords and key phrases extracted from the selected ENGOs' official websites that can be analyzed to demonstrate their resource mobilization strategies, we have employed several commonly used text mining procedures to identify keywords through the bag-of-words technique (Silver \& Levin, 2014; Usai et al., 2018). The extraction of keywords is "a concise representation of the article's content" (Vivek, 2018). Aggregately, these keywords can help researchers to identify major concepts in the climate change ENGOs' website contents.

The top five keywords with the highest frequency counts in our database are "Clean" (frequency $=207, \mathrm{TF}-\mathrm{IDF}=31.5)$, "Climate" $($ frequency $=163$, TF-IDF = 71.6), "Air" (frequency = 152, TF-IDF = 66.8), "Support" (frequency $=152, \mathrm{TF}-\mathrm{IDF}=32.2$ ), and "Work" (frequency $=145, \mathrm{TF}-\mathrm{IDF}=22.1$ ). 
TF-IDF, abbreviated from term frequency-inverse document frequency, is a weighing metric to examine the relative importance of a word in the corpus (Mirończuk, \& Protasiewicz, 2018, p. 42). TF-IDF statistics computes the occurrence of a word after modifying for the infrequency of its usage to help researchers recognize significant content words, appropriate to their research topics, by decreasing the weight of words such as "the," "a," or "an" commonly appeared in a document (UC Business Analytics R Programming Guide n.d.). The bag-of-words approach provides researchers with a list of TF-IDF metrics to identify the main features in the collected website contents (Usai et al., 2018). For example, as expected, keywords, such as "Climate" $($ TF-IDF $=71.6)$, "Air" (TF-IDF = 66.8), "Water" (TF-IDF = 51.2), "Ocean" (TF-IDF $=66.1)$, and "Recycle" (TF-IDF $=51.8)$, suggesting the main concerns of these climate change ENGO's websites in the United States.

For example, in terms of climate change ENGO's mobilization of human resources to recruit volunteers and participants, their website contents have shown most of these climate change ENGOs have relied on "Volunteers" (TFIDF = 17.7), "Participation" (TF-IDF = 11.5), and "Support" (TF-IDF = 9.4). To mobilize financial resources, the most salient keywords extracted from ENGO websites include "Support" (TF-IDF $=23.5)$ and "Donate" $($ TF-IDF $=17.8)$ (refer to Figure 2.1.2). In terms of climate change ENGOs' mobilization of technological resources, the data have shown the following keywords with the highest TF-IDF statistics: "Email" (TF-IDF = 5.8), "Technology" (TF-IDF = 5.2), "Newsletter" (TF-IDF = 4.9), "Actions" (TF-IDF = 4.9), and "Updates" $(\mathrm{TF}-\mathrm{IDF}=4.7)$ (refer to Figure 2.1.3). ENGO's outreach and networking programs are also essential to their capacity-building as demonstrated in the extracted keywords: "Community" (TF-IDF $=10.4)$, "Local" (TF-IDF $=13.4)$, "Public" (TF-IDF = 10.4), "Partner" (TF-IDF = 6.1), and "Businesses" (TF$\mathrm{IDF}=6.1)($ refer to Figure 2.1.4).

In terms of extracted key phrases, some interesting examples include "global warming" (TF-IDF $=20.5)$, "carbon dioxide" $($ TF-IDF $=20.5)$, "national security" (TF-IDF = 19.6, TF-IDF = 20.5), "clean energy" (TF-IDF = 13.9), "adaptation and mitigation" (TF-IDF = 11.0), and "human activity" (TF-IDF $=12.6$ ), indicating the common concerns among these ENGOs.

ENGOs, like most NGOs, measure their success on the basis of donations received, the growth of members and visitors, communities and their residents served, and the management of administrative cost (Sawhill \& Williamson, 2001). The growing use of online donation systems is an example of how NGOs have made the best of these technologies. Among 5,721 NGOs from 160 countries surveyed by Nonprofit Tech for Good (2019), 64\% of the NGOs accept electronic donation on their websites through credit cards, direct debit, and PayPal. Text solicitations sent to potential donor's mobile devices have also become a convenient method (Noel, 2020).

To answer our second research question about the relationship between ENGO characteristics and their resource mobilization strategies, we found that small ENGOs seem to rely more heavily on volunteers and their 


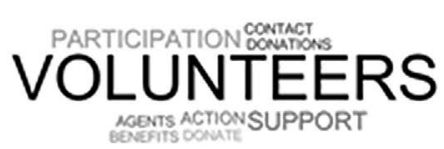

Figure 2.1.1

Human Resource Mobilization

\section{SUNATE \\ ENVIRONMENTAL}

Figure 2.1.2

Financial Resource Mobilization

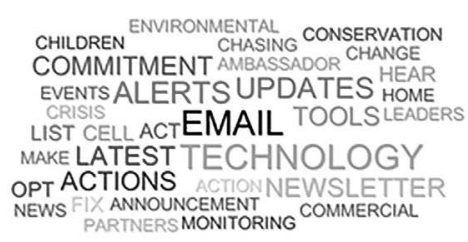

Figure 2.1.3

Technological Resource Mobilization

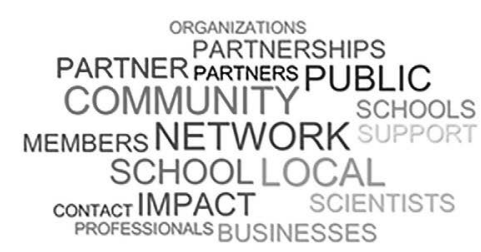

Figure 2.1.4.

Networking Resource Mobilization

Figure 2.1 Word cloud analysis of ENGOs' resource mobilization strategies.

participation as part of their human resource mobilization strategy to build their capacity. While donations carry almost equal importance for both small and large ENGOs, technology as a capacity-building tool plays a much more important role for small ENGOs, likely due to its cost-saving benefits such as sending out emails to potential donors and volunteers. However, the size of ENGOs could also influence their implementations of various technology platforms. For example, large ENGOs have more technology-proficient staff members to manage, create, and maintain Podcast contents and to distribute newsletters to update their members and stakeholders about their activities. Similar to their research on Nature Conservancy (Sawhill \& Williamson, 2001), ENGO's size could affect their networking with local community and businesses, with larger ENGOs have more resources to use technology for networking purposes. Larger ENGOs are found to emphasize their networking with them as their resource mobilization strategy.

\section{Discussions}

Findings from the text mining analyses of these climate change ENGOs' websites in the United States have identified different types of resource mobilization 


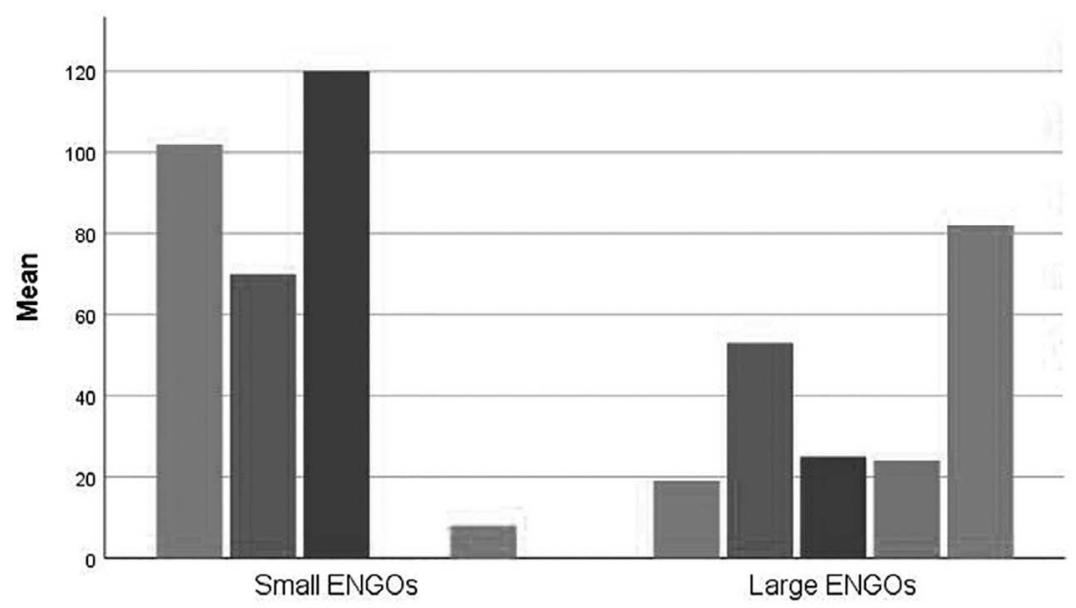

The Size of ENGOs

On Recruiting Volunteers as a Human Resource Mobilization Strategies

On Using Donations as a

Financial Resource Mobilization Strategy
On Using Technology as a Technological Resource Mobilization Strategy

On Using Podcast as a

Technological Resource Mobilization Strategy
On Networking with Community as a Resource Mobilization Strategy

Figure 2.2 The effects of ENGO size on resource mobilization strategies.

Note: The number reflects "rate per 10,000 words."

strategies to help build their organizational capacities. As reported in the ENGO capacity-building literature (Yang \& Kang, 2020; Upton, Tarin, Sowards, \& Yang, 2019), organization's capabilities to mobilize these critical resources are instrumental to the success of climate change ENGOs in terms of implementing social change programs, regardless of their organization size. For example, 350.org, a climate-centered ENGO in the United States, focuses on advocacy and lobbying to pass comprehensive pro-climate legislation to stop coal, gas, and oil projects by the fossil fuel industry, so their use can be phased out to protect biodiversity (350.org, n.d.; Hestres, 2013). As shown in its organization website, 350.org has employed a cashless online donation platform to request financial support for US\$10-350 to "build a powerful climate movement" (350.org, n.d.). Its website also provides links to the organization's Facebook, Instagram, and Twitter that can generate awareness and interest in 350.org, resulting in more donations.

In addition, past NGO research has reported that ENOGs can adopt technologies for staff training, volunteer use, and public outreach programs (Li \& 
Guo, 2015) to mobilize other resources critical to their success. Given the training of technology-proficient staff members is a costly endeavor, not to mention the implementation of digital technologies could be cost-inhibitive to many smaller ENGOs that do not have lot of budgets to fund the training and implementation of new technologies. As demonstrated in the text mining data, it is likely that the size of ENGOs will have significant effects on whether they are able to accomplish their social change missions and goals.

This study has confirmed through the tabulation of extracted keywords the increasingly vital role of ICTs in helping climate change ENGOs to mobilize scarce resources in the process of building their own capacities (Ballew, Omoto \& Winter, 2015). Extracted keywords such as "email," "technology," "cell," and "newsletter" among others have represented climate change ENGOs' efforts to integrate cashless e-commerce platforms, email communications, mobile devices, Podcast, and social media platforms into their mobilization strategies.

Despite our data of these 44 ENGO websites were collected before the spread of coronavirus pandemic around the world, climate change ENGOs' capabilities to mobilize resources are even more critical during the postCOVID 19 era when their funding could be severely impacted (O'Connell, 2020). The climate change ENGOs, such as 350.org, have repositioned their mission to deal with the global crisis, as seen in the following statement: Much like the climate crisis, this COVID-19 outbreak challenges us to think about resilience and the communities and social solidarity we'll all need for an uncertain future (350.org, n.d. https://350.org/coronavirus-organizing/).

This text mining study of website contents contributes to our understanding of what climate change ENGOs in the United States have done to take advantage of the most commonly available website technology to help with their capability-building efforts. As an integrated platform, ENGOs' official websites also enable them to include many emerging ICTs (such as social, mobile, Podcast, and e-commerce platforms) that are instrumental to people's pro-environmental actions (Anderson, 2017; Ballew et al., 2015). The integration of various ICTs have contributed to building human and financial resources for these climate change ENGOs. For example, $1 \%$ for the Planet Inc. has employed a mobile platform that any interested donor can text "Planet" to 44321 to the amount and the frequency of their donations.

Despite the hyperbole about what advanced ICTs (such as artificial intelligence) can do for NGOs (Kesari, 2019), the availability of resources will affect these technologies (Yang \& Kang, 2020). For example, 1\% for the Planet Inc., a well-funded ENGO with 3,000 member and over US\$250 million budget, can afford to support a wide variety of environmental causes by pairing businesses and ENGOs to maximize the impacts of member donations. ${ }^{2} 1 \%$ for the Planet Inc. has abundant financial resource to adopt a multi-platform strategy to deliver its Podcast episodes through Apple Podcast, Spotify, Stitcher, and website platforms. This strategy allows this ENGO to share "fascinating stories from leaders, musicians, photographers, 


\section{Kenneth C. C. Yang and Yowei Kang}

adventurers, environmentalists and everyday people from all walks of lifewho have a deep connection to our planet, and a commitment to save it" (1\% for the Planet Inc., n.d., https://www.onepercentfortheplanet.org/psa). Listening to these personal testimonials also helps the public to learn more about this ENGO to become a member, a volunteer, or even a donor.

Our text mining study also helps environmental communication scholars and practitioners to understand what technologies as resource mobilization tools have been used. As identified in the word cloud figures, keywords such as "email," "newsletter," "network," "technology," and "tool" demonstrate that climate change ENGOs have increasingly employed these ICTs to consolidate "a nonprofit's ability to fulfill its mission over time, thereby enhancing the nonprofit's ability to have a positive impact on lives and communities" (National Council of Nonprofits, n.d., n.p.). For example, 350.org has employed its website to shape public political opinions (Hestres, 2013). In February 2012, over 800,000 emails from anti-Trans Alaska Pipeline activists and ENGOs (including 350.org) are sent to the US Senate to lobby against the pipeline legislation, suggesting the usefulness of ICTs in shaping policymaking processes and outcomes (Hestres, 2013).

The text mining of ENGOs' textual webpages also confirms that website and email platforms continue to be the primary ICT platforms adopted by NPOs in the United States and Canada, with $97 \%$ of these organizations owning a website (Nonprofit Tech for Good, 2019). The same survey has also reported $82 \%$ of NPOs send email updates to their supporters (Nonprofit Tech for Good, 2019). Findings from this text mining study confirms the prevalence of using email and newsletter among climate change ENGOs in the United States, as shown by its occurrence in the website contents. Insights from both studies may help practitioners to adopt the most effective ICT platforms when planning their own technology strategies.

Extracted keywords from these ENGOs' websites describe the diversity of technology uses in mobilizing resources to build their core organizational capacities to mobilize human, financial, and technological resources in terms of staff training, volunteer recruitment, and outreach programs (Li \& Guo, 2015). Recurrent keywords such as "volunteer," "participation," "donate," "support," "partnerships," "partner," and "community" among others have shown that these ENGOs have a clear vision as to how their official websites can help them to mobilize many critical human, financial, and networking resources through dissemination and sharing of environmental messages easily and quickly (Good, 2006). For example, the organization website of 350 .org has become a multimedia platform to foster a new global movement for climate change by raising awareness, enhancing knowledge, and calling for action among the public. In the case of 350.org and many other climate change ENGOs, their social movement to shape public's perceptions of climate change risks can lead to the mobilization of public opinions as their own political resources, contributing to pro-climate change legislations in the political process (Overby \& Ritchie, 1991). 


\section{Conclusion}

According to The United Nations Framework Convention on Climate Change (UNFCCC), climate change should not be tackled merely as a scientific problem; its negative impacts on human rights should be considered to prevent any "adverse effects on people's health and welfare" (Article 1) (cited in the United Nations Task Team on Social Dimensions of Climate Change, 2011). An average of US $\$ 149.5$ billion dollars has been lost, from 2000 to 2017, due to extreme weather patterns (Statista, 2019). Sixty-four percent of Americans report climate change is a crisis and a serious problem, and should be dealt with right now $(56 \%)$ or within next few years $(13 \%)$ (CBS News Poll, cited in Pinto, Backus, \& Salvanto, 2019). After reading this study, other ENGOs should realize the importance of ICTs as indispensable for ENGOs to mobilize their resources through receiving funding, facilitating collaboration among their members, partners, and outside communities, and even cultivating their own capacities to employ these technologically smartly (De Vita et al., 2001; Hestres, 2013; Faulkner et al., 2013).

Our study also describes how these technologies have been currently employed by climate change ENGOs in the United States, on the basis of text analyzing their webpages. Evidently, websites, emails, newsletters, mobile, and cashless donation platforms can be easily set up by other NGOs to allow them to recruit volunteers, network with local communities and supporters, and receive donations without the hurdles of untrained staff and technological barriers. Our study also confirms the relationship between the size of ENGOs and their ICT applications, suggesting NGOs should take into consideration their own existing financial, technological, and human resource capacities when planning and implementing ICT-enabled resource mobilization activities. Employing the most accessible and popular technologies (such as websites and emails) that NGOs' staff members are familiar with seems to be the best practice recommendation without overspending on technology and staff training.

However, scholars should be cautioned that, when interpreting our findings, several research limitations should be acknowledged. First, the text mining methods are inherently limited by the type and the number of ENGOs' websites included in the database. Second, many scholars who have adopted the computational data processing methods also alert that text mining methods also have several methodological limitations (Lin, Hao, \& Liao 2016). For example, the comprehensiveness of the corpus from the selected climate change ENGOs will affect the findings. Furthermore, transparency and clarity in the text mining analysis undoubtedly will influence the results (Lin et al., 2016).

\section{Notes}

1. https://www.guidestar.org/nonprofit-directory/environment-animals.aspx

2. https://www.onepercentfortheplanet.org/ 


\section{Kenneth C. C. Yang and Yowei Kang}

\section{References}

ACDEF. (n.d.). Resource mobilization \& capacity building (RMCB). Cambridge, UK: ACDEF. Retrieved May 24, 2020, from https://www.acdef.org/rmcbp/

American Psychological Association (2020, February 7). Majority of US adults believe climate change is most important issue today: Nearly half of 18-34 year olds say that stress about climate change affects their lives. ScienceDaily. Retrieved June 4, 2020, from www.sciencedaily.com/releases/2020/2002/200207095418.htm

Anderson, A. A. (2017, March). Effects of social media use on climate change opinion, knowledge, and behavior. Oxford Research Encyclopedia of Climate Science, 1-20.DOI: 10.1093/acrefore/9780190228620.9780190228013.9780190228369.

Ballew, M. T., Omoto, A. M. \& Winter, P. L. (2015). Using Web 2.0 and social media technologies to foster pro-environmental action. Sustainability, 7, 10620-10648.

Blue Planet (n.d.). About. Retrieved December 9, 2020, from https://blueplanet foundation.org/about/

Brulle, R. J. (1996). Environmental discourse and social movement organizations: A historical and rhetorical perspective on the development of U.S. environmental organizations. Sociological Inquiry, 66(1), 58-83. https://doi.org/10.1111/j.1475682X.1996.tb00209.x

Büscher, B. (2014). Nature 2.0: Exploring and theorizing the links between new media and nature conservation. New Media \& Society, 1-18.

Byrd, R. \& DeMates, L. (2014, October 6). 5 reasons why climate change is a social issue, not just an environmental one. HuffPost. Retrieved July 18, 2020, from https://www.huffpost.com/entry/climate-change-is-a-socia_b_5939186.

De Vita, C. J., Fleming, C. \& Twombly, E. C. (2001). Building nonprofit capacity: A framework for addressing the problem. In C. J. De Vita \& C. Fleming (Eds.), Building capacity in nonprofit organizations (pp. 5-30). Washington, DC: The Urban Institute.

Diakopoulos, N., Zhang, A. \& Salway, A. (2013, October 13-18). Visual analytics of media frames in online news and blogs. IEEE InfoVis Workshop on Text Visualization, Atlanta, Georgia, USA.

Dickerson, K., Torres, D., Canet, J.-M., Smiciklas, J., Faulkner, D., Bueti, C. \& Vassiliev, A. (2011). Using ICTs to tackle climate change. International Telecommunication Union (ITU) and global e-substainability initiative. Retrieved July 20, 2020, from https://www.itu.int/dms_pub/itu-t/oth/2020B/2011/T2020B1100000A110 3301PDFE.pdf

Environmental Defense Fund (n.d.). Together, we create lasting solutions to our biggest environmental challenges. Retrieved December 9, 2020, from https://www. edf.org/

Faulkner, D., Ospina, A. V., Dickerson, K. \& Bueti, C. (2013, October 31). Climate change adaptation and ICTs. ITU and climate change. Retrieved July 19, 2020, from https:/www.itu.int/en/ITU-T/Workshops-and-Seminars/20131021/Documents/ P20131022_Dave_Faulkner.pdf

Finger, L. T. M. (2001). Environmental organizations: Changing roles and functions in global politics. Global Environmental Politics, 1(1), 56-76.

Global Commission on Adaptation (2019, September 13). Adapt now: A global call for leadership on climate resilience. The global commission on adaptation. Retrieved July 19, 2020, from https://cdn.gca.org/assets/2019-2009/GlobalCommission_Report_FINAL.pdf 
Good, J. (2006). Chapter Ten: Internet use and environmental attitudes: A social capital approach. In Depoe, S. P. (Ed.), The environmental communication yearbook (Volume 3) (pp. 211-233). doi: 210.1207/s15567362ecy15560301_15567310). Abingdon, UK: Routledge.

Hase, V., Engelke, K. M. \& Kieslich, K. (2020). The things we fear. Combining automated and manual content analysis to uncover themes, topics and threats in fearrelated news. Journalism Studies, 21(6), 1-19. doi: 10.1080/1461670X.1462020. 1753092

He, W., Zha, A. \& Li, L. (2013). Social media competitive analysis and text mining: A case study in the pizza industry. International Journal of Information Management, 33(3), 464-472.

Hestres, L. E. (2014). Preaching to the choir: Internet-mediated advocacy, issue public mobilization, and climate change. New Media \& Society, 16(2), 323-339.

Jang, S. M., \& Hart, P. S. (2015). Polarized frames on "climate change" and "global warming" across countries and states: Evidence from Twitter big data. Global Environmental Change, 25(3), 11-17.

Kang, Y. W. \& Yang, K. C. C. (2018, October 27-29). A text mining exploration of mainstream and social media discourses on internet censorship and privacyinvasive information-communication technologies (ICTS) in china: A cultural ecological analysis. Paper presented at the new paradigms communication education stream, the Asian congress for media and communication (ACMC) 2018 international conference, National Chengchi University, Taipei, Taiwan.

Kesari, G. (2019, December 20). How NGOs can leverage AI without breaking the bank. T_HQ (Technology and Business). Retrieved December 10, 2020, from https:// techhq.com/2019/2012/how-ngos-can-leverage-ai-without-breaking-the-bank/.

Knittel, C. (2019, October 28). Opinion: Five reasons climate change is the worst environmental problem the world has ever faced. Los Angeles Times. Retrieved on May 24, 2020, from https://www.latimes.com/opinion/story/2019-2010-2028/ climate-change-global-pollutants

Kobayashi, V. B., Mol, S. T., Berkers, H. A., Kismihók, G. \& Hartog, D. N. D. (2018, July). Text mining in organizational research. Organization Research Methods, 21(3), 733-765. doi: 710.1177/1094428117722619.

Laporte, S., Kelly, D. \& Agbabiaka, T. (2018, May 29). Can technology transform the nonprofit sector? Yale Insights. Retrieved May 23, 2020, from https://insights. som.yale.edu/insights/can-technology-transform-the-nonprofit-sector

Li, C. \& Guo, J. (2015). Capacity-building development since the 1990s. Asian Social Work and Policy Review, 9, 79-93.

Li, H., Tang, S.-Y. \& Lo, C. W.-H. (2018). The institutional antecedents of managerial networking in Chinese environmental NGOs. Nonprofit and voluntary Sector Quarterly, 47(2), 325-346.

Lin, F.-R., Hao, D. \& Liao, D. (2016). Automatic content analysis of media framing by text mining techniques. Paper presented at the 2016 49th Hawaii international conference on system sciences, Hawaii, USA.

Marlon, J., Howe, P., Mildenberger, M., Leiserowitz, A., \& Wang, X. (2019, September 17). Yale climate opinion maps 2019. Yale Program on Climate Change. Retrieved April 23, 2020, from https://climatecommunication.yale.edu/ visualizations-data/ycom-us/

McCarthy, J. D., \& Zald, M. N. (1977, May). Resource mobilization and social movement: A partial theory. American Journal of Sociology, 82(6), 1212-1241. 


\section{Kenneth C. C. Yang and Yowei Kang}

McPhee, P., \& Bare, J. (2011). Introduction. In C. J. De Vita \& C. Fleming (Eds.), Building capacity in nonprofit organizations (pp. 1-3). Washington, DC: The Urban Institute.

Mitchell, R. C., Mertig, A. G. \& Dunlap, R. E. (1991). Twenty years of environmental mobilization: Trends among national environmental organizations. Society and Natural Resources: An International Journal, 4(3), 1970-1990.

Mirończuk, M. M. \& Protasiewicz, J. (2018). A recent overview of the state-of-theart elements of text classification. Expert Systems with Applications, 106, 36-54.

Mogus, J. \& Levihn-Coon, A. (2018, February 6). What makes nonprofit digital teams successful today? Stanford Social Innovation Review. Retrieved May 23, 2020, from https://ssir.org/articles/entry/what_makes_nonprofit_digital_teams_ successful_today

National Council of NonProfits. (n.p). Retrieved July 25, 2018, from https://www. councilofnonprofits.org/tools-resources/what-capacity-building

Nah, S. \& Saxton, G. D. (2013). Modeling the adoption and use of social media by nonprofit organizations. New Media \& Society, 15(2), 294-313.

Noel, C. (2020, May 20). The essential tech elements for virtual fundraising events. Nonprofit Tech for Good. Retrieved May 23, 2020, from https://www.nptechfor good.com/2020/2005/2022/the-essential-tech-elements-for-virtual-fundraisingevents/

Nonprofit Tech for Good (2019). Global NGO technology report 2019. Nonprofit Tech for Good. Retrieved May 22, 2020, from https://assets-global.website. files. com/5d6eb414117b673d211598f2/5de82e1550d3804ce13ddc75_2019-TechReport-English.pdf

NPO Information Consultation Center (2003). NPO capacity building and the international experience. Beijing: Huaxia Press.

Pinto, J. D., Backus, F. \& Salvanto, A. (2019, September 15). Most Americans say climate change should be addressed now-CBS News poll. CBS news. Retrieved May 24, 2020, from https://www.cbsnews.com/news/cbs-news-poll-mostamericans-say-climate-change-should-be-addressed-now-2019-2009-2015/

O'Connell, S. (2020, April 2). How to reform NGO funding so we can deal with threats like COVID-19. World Economic Forum. Retrieved June 4, 2020, from https://www.weforum.org/agenda/2020/2004/how-to-reform-ngo-funding-so-wecan-deal-with-threats-like-covid-2019/

Overby, L. M. \& Ritchie, S. J. (1991). Mobilized masses and strategic opponents: A resource mobilization analysis of the clean air and nuclear freeze movements. Western Political Quarterly, 44(2), 329-351.

Ogunbode, T. O., Ogungbile, P. O., Odekunle, D. \& Asifat, J. T. (2019). Climate change awareness and its determinants in a growing city in the Southwestern Nigeria using multivariate analysis. Journal of Environmental Sustainability, 7(1), 15-27. https://scholarworks.rit.edu/jes/vol17/iss11/12

Saxton, G. D. \& Guo, C. (2014). Online stakeholder targeting and the acquisition of social media capital. International Journal of Nonprofit and Voluntary Sector Marketing, 19(4), 286-300.

Saxton, G.D. \& Guo, C. (2012). Conceptualizing web-based stakeholder communication: The organizational website as a stakeholder relations tool. Communication \& Science Journal. Retrieved October 18, 2018, from http://www.galileoco.com/ comSciJliterature/saxtonGuo12.pdf 
Sawhill, J., \& Williamson, D. (2001, May 1). Measuring what matters in nonprofits. Washington, DC: McKinsey \& Company. Retrieved June 1, 2020, from https://www.mckinsey.com/industries/social-sector/our-insights/measuringwhat-matters-in-nonprofits

Schumaker, R. P., Zhang, Y., Huang, C. N. \& Chen, H. (2012). Evaluating sentiment in financial news articles. Decision Support Systems, 53(3), 458-464.

Silver, C. \& Lewins, A. (2014). Using software in qualitative research: A step-by-step guide. Thousand Oaks, CA: Sage Publications.

Soule, S. A., \& King, B. G. (2008). Competition and resource partitioning in three social movement industries. AJS, 113(6), 1568-1610.

Statista. (2019). Global climate change. New York, NY: Statista Inc.

Teso, E., Olmedillab, M., Martínez-Torresc, M. R. \& Toral, S.L. (2018). Application of text mining techniques to the analysis of discourse in eWOM communications from a gender perspective. Technological Forecasting and social Change, 129, 131-142.

The New Climate Economy (2016). The sustainable infrastructure imperative. Washington, DC: The new climate economy. Retrieved July 18, 2020, from http://newclimateeconomy.report//2016

The New Climate Economy (2018). The 2018 report of the global commission on the economy and climate. Washington, DC: The new climate economy. Retrieved on July 18, 2020, from http://newclimateeconomy.report//2018

The United Nations Task Team on Social Dimensions of Climate Change (2011). The social dimensions of climate change. The United Nations task team on social dimensions of climate change, Retrieved July 19, 2020, from https://www.who.int/ globalchange/mediacentre/events/2011/social-dimensions-of-climate-change.pdf

Yang, K. C. C., \& Kang, Y.W. (2020). Employing digital media technologies for environmental communication campaigns in People's Republic of China. In Pont, J. D., Maeseele, P., Sjölander, A.E., Mishra, M., \& Foxwell-Norton, K. (Eds.), When the local meets the digital: Implications and consequences for environmental communication (pp. 49-67). IMACR Palgrave Series. doi: 10.1007/978-3-030-37330-6_3

UC Business Analytics R Programming Guide. (n.d.). Text mining: Term vs. document frequency. Text mining: Term vs. document frequency, Retrieved January 4, 2020, from https://uc-r.github.io/tf-idf_analysis

United Nations climate change (UNFCCC). (2019a, September 10). Global leaders call for urgent action on climate adaptation. United Nations climate change (UNFCCC), Retrieved on July 19, 2020, from https://unfccc.int/news/global-leaders-call-forurgent-action-on-climate-adaptation

United Nations climate change (UNFCCC). (2019b, September 12). Capacity-building is key to boost regional climate action. United Nations climate change (UNCC), Retrieved July 19, 2020, from https://unfccc.int/news/capacity-building-is-key-toboost-regional-climate-action

Upton, S.D., Tarin, C.A., Sowards, S. K. \& Yang, K. C.C. (2019). Rare's conservation campaigns: Community decision making and public participation for behavioral change in Indonesia, China, and Latin America. In Hunt, K., Walker, G.B. \& Depoe, S.P. (Eds.), Breaking boundaries: Innovative practices in environmental communication and public participation (pp. 227-246). Albany, NY: SUNY Press.

Usai, A., Pironti, M., Mital, M. \& Mejri, C.A. (2018). Knowledge discovery out of text data: a systematic review via text mining. Journal of Knowledge Management, 22(7), 1471-1488. Retrieved from https://doi.org/1410.1108/JKM-1411-2017-0517. 


\section{Kenneth C. C. Yang and Yowei Kang}

Viravaidya, M., \& Hayssen, J. (2001). Strategies to strengthen NGO capacity in resource mobilization through business activities. Geneva, Switzerland: UNAIDS. Retrieved May 24, 2020, from http://data.unaids.org/publications/irc-pub06/ jc579-strategies_ngo_en.pdf

Vivek, S. (2018, December 17). Automated keyword extraction from articles using NLP. Analytics Vidhya, Retrieved April 24, 2020, from https://medium.com/analyticsvidhya/automated-keyword-extraction-from-articles-using-nlp-bfd2864f204 1 b2034

World Health Organization (WHO) (2015). Effects of climate change on the social \& environmental determinants of health in Africa: What can communities do to strengthen their climate resilience? World Health Organization (WHO). Retrieved July 18, 2020, from https:/www.climhealthafrica.org/wp-content/uploads/2016/ 2001/Effects-of-Climate-Change-on-the-Social-and-Environmental-Determinantsof-Health.pdf

Xu, D. Y., Kang, X. W., Zhuang, D. F. \& Pan, J. J. (2010, April). Multi-scale quantitative assessment of the relative roles of climate change and human activities in desertification: A case study of the Ordos Plateau, China. Journal of Arid Environments, 74(4), 498-507. 


\title{
3 The Strategy of NGO Journalism in the Fight for Refugee Rights
}

\author{
Delaney Harness
}

The relationship between non-governmental organizations (hereafter NGOs) and news bureaus was once thought to be symbiotic, with NGOs developing press releases and policy reports that newsrooms would then turn into news stories (Thrall, Stecula \& Sweet, 2014). However, the collapse of American international news coverage over the last 30 years, has caused news organizations to shutter foreign news bureaus and let go of foreign correspondents (Abbott, 2009; Fenton, 2010; Powers, 2017). Subsequently, NGOs have had to adapt and strategize new ways to reach key stakeholders and policymakers. In this sense, we can say that NGOs have hybridized their journalism function, moving beyond a simple press release to researching, producing, and disseminating their own content in prepackaged, often innovative ways that rival or surpass the capabilities of more traditional news outlets (Powers, 2018; Wright, 2016).

As proponents of social change and advocates for human rights, NGOs use journalism to communicate their humanitarian agenda and promote their human rights efforts. Keck and Sikkink (1998) note that NGOs are expected to engage with and raise public awareness of critical social issues. In the US context, this has been muddied in recent years, with NGOs under greater scrutiny by stakeholders and the general public, calling for transparency about their financial management, aid, and advocacy practices (Wasik, 2013). Consequently, these same NGOs balance a careful line between professionalism and corporatism (Yanacopulus, 2015). As a result, NGOs often prioritize issues that will receive the most significant media coverage, thus neglecting "lesser issues" (Ron, Ramos, \& Rodgers, 2005). For their part, journalists have necessarily played an important role in discerning between an NGOs agenda and "giving voice" to marginalized people.

Historically, media partnerships with newspapers and television have helped craft and curate the human rights agenda for policymakers and the general public. In the 1960s and 1970s, NGOs looked to foreign bureaus to produce and spread human rights stories to mass audiences (Powers, 2018). However, the revolution in digital platforms and social media have made news more accessible and expedient, meaning news organizations have to seek alternative revenue streams and cut costs in places like international

DOI: $10.4324 / 9781003188636-5$ 
news (Abbott, 2009). Consequently, news organizations now rely on networks of NGOs to produce stories, using NGO's briefings, photos, and video content (Wright, 2016). Moreover, access to digital platforms mean NGOs are less reliant on legacy media partnerships and can shift focus to developing their own digital strategies.

In some regard, digital tools have allowed NGOs to expand and hybridize publicity and public outreach (Chadwick, 2013). McPherson (2015) explains that Amnesty International and Human Rights Watch have become "verification subsidy" for news organizations investigating human rights issues. But there is continued debate among scholars over whether NGO journalism is a help or hindrance in setting the human rights agenda. Powers (2017), for his part, argues that reframing the conversation to consider how NGOs use a particular normative journalism frame relieves some of this tension and can help explain how NGOs satisfy a particular group's needs. In this capacity, they take on one of four roles: expert, advocate, facilitator, or critic, with expert and advocate being the dominate roles. However, NGOs are uniquely positioned to produce content and coverage of social issues beyond the capability of news organizations (Lück, Wozniak, \& Wessler 2016; Russell, 2013).

Nowhere is this truer perhaps than in the so-called global refugee crisis. The start of the Syrian Civil War compounded by instability in South America and droughts in other parts of the world have forced individuals from their homes and lands, searching for safety in places like the United States and Europe. But nation states have pushed back against this perceived invasion, leaving many refugees in uninhabitable living conditions. NGOs have consequently altered their strategy toward policymakers and decision-makers as they push for refugee rights. This chapter considers the following research question: How and why have NGOs altered or adapted normative journalism roles to push for refugee rights? This chapter begins by positioning itself within journalistic coverage of refugees and asylum seekers to the United States, and then takes up the discussion of normative journalism theories. From there, I use a case study of refugee rights campaigns from two NGOs, Human Rights Watch and Human Rights First, to elucidate the important role that technology has necessarily played in how NGOs engage with normative journalistic roles to further refugee rights, and how NGOs adapt or alter journalistic roles to call out migrant human rights violations. In raising this question, I hope to explore meaningful forms of NGO social change and assess how NGOs may adopt journalism as part of their communication strategy.

\section{Reporting on Refugees}

In 2011, the Syrian War, followed closely by the rise of ISIS, caused many to flee their homes for safer shores. Compounded by gang violence and government persecution in South America, 2015 saw the start of a refugee crisis. The United States has long been a refugee and asylum resettlement leader, but the 
influx of appeals during the Obama administration raised concerns for an already overtaxed system. The subsequent rise of the Trump administration completely gutted the rest of the infrastructure.

Today, refugees face some of the strictest and austere immigration policies when applying for refugee or asylum status in the United States. The Trump administration's "Remain in Mexico" policy enforced by Migrant Protection Protocols has left some 67,000 individuals in a perpetual state of limbo (Selsky \& Whittle, 2019). Living conditions on the southern border are abysmal, with a lack of clean water, and according to the Houston Chronicle, one bathroom for every 60 people (Barnett, 2020). Coupled with the zero-tolerance policy that separated children from their family members trying to covertly cross the border, some 545 children are now in foster care because US officials cannot locate their parents.

In 2019, the United Nations High Commission for Refugees Global Trends Report found that of the 26 million displaced people worldwide, nearly 1.5 million needed resettlement. Historically, the United States has led the world in refugee resettlement, but the numbers have drastically decreased under the Trump administration. The United States admitted 11,814 refugees in 2020 , compared to the 85,000 admitted in 2016 , an 86 percent decrease (Frelick, 2020). The Trump administration has been more effective in its immigration policy constraint than any other area (Scribner, 2017), specifically in its policies toward refugees and asylum seekers from the Middle East and South America.

In journalism, refugees are often framed as marginalized, powerless victims, sometimes referred to as a paternalist frame (Benard, 1986; Freedman, 2010). More recently, they have been perceived as threatening (Van Gorp, 2005). Rather than victims, they are viewed as criminals or security risks (Chávez, 2012; Ono \& Sloop, 2002; Wang, 2012). News coverage plays a key role in the mediation of these stereotypes and negative coverage has only increased over time (Phillips \& Spinks, 2013). Media frames often focus on the "legitimacy" or "illegality" of asylum seekers (McKay et al., 2012; Rowe \& O’Brien, 2014). Further, there are questions of social cohesion, border security, and threats to the way of life (Bleiker et al. 2013; Pederson \& Hartley, 2015). News stories have damaging consequences that trigger, alter, or reinforce negative attitudes and beliefs toward refugees and asylum seekers (Flores, 2003; Schemer, 2012). These mythologizing narratives create "predictable plots, recognizable characters, broadly held values, and culturally accepted morals" (Berkowitz \& Liu, 2014, p. 306).

NGOs advocating for the refugee population must work to combat negative stereotypes and damaging stigmas in their own reporting. While NGOs seek to ease the burdens placed on refugees, states strive to maintain and control their borders (Phillips \& Hardy, 1997). Therefore, NGOs frame refugee incidents in individual and emotional episodic frames (Ihlen, Fienschou \& Larsen, 2015). This often appears as stories focused on individuals or families rather than refugees as a collective. These frames are 
considered humanizing, which directly contradicts national news coverage that is typically dehumanizing and thematic (Cooper, Olejniczak, Lenette \& Smedley, 2017). Alternatively, NGOs tend to portray refugees as autonomous, empowered decision-makers (Ihlen, Fienschou, \& Larsen, 2015). Positive stories help challenge the negativity refugees face in the process of resettlement (Pedersen \& Hartley, 2015), and stories that criticize state governments' handling of refugees have a better chance of swaying public opinion (Cooper et al. 2017). However, the NGO discourse for refugees is often contradictory, partly because NGOs hope to influence a wide range of actors from governments and stakeholders to the refugees themselves.

To date, the normative construction of refugees and asylum seekers is othering and all together derogatory. In the United States, foreign and immigration policy during the Trump administration has attacked and persecuted refugees and asylum seekers. With the Muslim Ban in 2017, where many refugees were stuck in a perpetual limbo; the inhumane child separation policy that broadcast children in cages worldwide; and the devastating living conditions faced by many on the southern border waiting to hear about their asylum cases, the Trump administration has systematically torn apart an already broken immigration system. It is now the work of NGOs to act as experts, advocates, facilitators, and critics to effect change in US immigration policy. The chapter continues by exploring four normative theories of journalism and the role of NGOs with these frames, and then analyzes the news campaigns of two US-based human rights NGOs that work on challenging the construction of refugee and asylum seeker narratives in the United States. Through this comparison, we see the shifting news roles NGOs use to fight for refugee rights in the United States.

\section{Normative Theories of NGO Journalism}

The emergent use of NGOs in news production has, in some sense, altered the expectation of journalism norms in the United States. Powers (2017) explains four normative traditions of public communication: representative liberalism, participatory democracy, discursive, and radical democracy (see Table 3.1). This framework is particularly useful in demonstrating how NGOs alter and adapt their journalistic positioning based on the goals and audience they hope to reach. Within each of these traditions, NGOs perform four journalism roles as experts, advocates, facilitators, or critics. Powers notes that most NGOs act within a representative liberalism or participatory democracy frame, meaning they are most often experts or advocates. However, social media and digital strategies have begun to alter the normative role of NGOs in journalism, particularly in the case of refugee rights.

Powers (2017) explains that in the normative tradition of representative liberalism, NGOs act as experts that write toward an elite-oriented audience striving for accuracy and transparency to appear impartial. Within this tradition, NGOs are expected to provide factual, evidence-based information 
Table 3.1 Roles of NGOs in normative journalism traditions

\begin{tabular}{|c|c|c|c|}
\hline Journalism Tradition & Role of NGO & Audience of NGO & News Voice of NGO \\
\hline $\begin{array}{l}\text { Representative } \\
\text { liberalism }\end{array}$ & Expert & Elite-oriented & Impartial \\
\hline $\begin{array}{r}\text { Participatory } \\
\text { democratic }\end{array}$ & Advocate & Lay people/public & Advocative \\
\hline Discursive & Facilitators & Public & Deliberative \\
\hline Radical democratic & Critics & Social peripheries & Critical \\
\hline
\end{tabular}

Source: Adapted from Powers, 2017.

that appears objective (Ferree et al., 2002), creating what Lippman (1922) refers to as the "machinery of record." In this tradition, society is considered complex and beyond the comprehension of everyday laypeople, who are not expected to engage in politics or civil society more broadly. Therefore, NGOs write toward and rely on government representatives and other experts to generate news, seemingly representing two sides of an issue to develop impartiality among the elites (Schudson, 2008). For example, Human Rights Watch and Human Rights First leverage their knowledge and expertise on refugee rights to gain access to new outlets.

In participatory democratic traditions, NGOs act as advocates that write toward a broad audience to raise awareness and create participation. In this tradition, social life is also considered complex and differentiated, but the goal is to develop civic participation. Unlike representative liberalism, participatory democracy assumes that laypeople can and should learn about civic engagement. A wide array of communicative styles are accepted within this perspective, but news media are used to create interests in politics (Dewey, 1927; Gans, 2003; McNair, 2000). Keck and Sikkink (1998) argue that a key role for NGOs is creating public awareness, but Powers (2017) argues for a distinction between "public awareness" and "public competency" in social issues. One particular example of NGOs using a participatory democratic frame is through Human Rights First use of virtual reality and news games to explore the lives and living conditions of refugees. This new communicative style is meant to appeal to lay people and raise public awareness.

In discursive traditions, journalists also write to promote civic engagement. In this tradition, NGOs act as facilitators that write toward a public audience, but the goal is to encourage dialogue and debate. In this sense, civic engagement promotes a Habermasian perspective of the public sphere, where debate and dialogue are treated as necessary steps toward a creation of norms. NGOs thus act as intermediaries between civil society's cross sections and work to widen perspectives, invite alternative discourses, and facilitate the deliberative process (Benhabib, 2002; Gastil, 2008). Examples of this tradition are town halls, editorial dialogues between varying perspectives in news publications, and in some cases the comment section of news. 
Finally, in radical democratic traditions, NGOs act as critics that write toward the social peripheries to expose social injustice. In this tradition, NGOs "root out" systemic social inequalities such as race, gender, class, sexuality, and disability (Curran, 2005; Ferree et al. 2002; Christians et al., 2009). In part, this perspective draws on the muckraker tradition from the industrial revolution that worked to expose ill-treatment and harsh working and living conditions of laborers in the late 19th and early 20th centuries. As critics, NGOs are suspicious of government news agendas, working instead to provide peripheral perspectives and liberate or emancipate those living on society's margins (Benson, 2008). Radical democratic traditions use a wide range of communicative styles to garner attention but, more importantly, overturn the status quo (Downing, 2001; Fenton, 2010; Powers, 2017).

Powers (2017) notes that NGOs ascribe to representative liberalism and participatory democratic perspectives, playing expert or advocate. He primarily criticizes NGOs for failing to act as facilitators or critics because they use journalism to create publicity for fundraising (Powers, 2015a; Ramos, Ron, \& Thoms, 2007). NGOs have also been critiqued for failing to develop journalistic norms that are required in radical democracy (Cottle \& Nolan, 2007), often eschewing discussions about root causes of systemic issues (Nash, 2008). However, an area that has seen journalistic shifts, perhaps even hybridization of news roles, is within the global refugee and asylum seeker crisis.

\section{NGO Refugee Advocacy in the United States: Two Cases}

NGOs play a critical role in refugee advocacy, disseminating information, developing persuasive messaging, and implementing policy and legislation. Hall (2019a) explains that NGOs create advocacy campaigns around their own issue expertise, and refugee rights are particularly salient because they are both timely and there is a heavy norm contestation between state actors and NGOs (Hall, 2019b). This is to say that there are competing views on what to do and how to treat refugees and asylum seekers. This chapter takes up the refugee campaigns of two NGOs, Human Rights Watch and Human Rights First, as representatives of large- and small-scale NGOs with proven refugee rights expertise. Human Rights Watch is a large international NGO founded in the United States that has become a leader in refugee rights and is recognized by the United Nations and the European Union for its contribution to the human rights agenda. Concurrently, Human Rights First is a smaller US-based NGO; their cornerstone initiative is refugee rights and they have been an important driver behind more equitable US immigration policy. In comparing the journalism roles these NGOs use in their refugee campaigns, I demonstrate how NGOs effectively alter or adapt their journalistic role based on the importance of the issue and stance of other actors, and how digital technologies have altered or hybridized the roles NGOs use to push for refugee rights. 


\section{Human Rights Watch and Refugee Rights}

Human Rights Watch (hereafter HRW) was founded in 1978 as Helsinki Watch to monitor Russia's compliance in the Helsinki Accords. Later groups included Asia Watch, Americas Watch, Africa Watch, and Middle East Watch. In 1988, these watches formed under one umbrella as the Human Rights Watch. Its offices are now worldwide, for instance, in New York, Beirut, Berlin, Johannesburg, Sydney, and Tokyo (Human Rights Watch [HRW], 2017). With an operating budget of $\$ 60$ million a year, HRW, specifically, acts as a watchdog against states violating human rights. The organization is also known for the research it conducts and publishes for human rights policies and programs. In many ways, it has become a titan for NGO journalism. HRW is sometimes considered a "gatekeeper" among other NGOs because it promotes and sets the normative agenda and often influences state actors through "naming and shaming" (Hertel, 2006). HRW's motto "Investigate, Expose, Change" instills the organization's goal to produce comprehensive investigations of human rights abuses, using news media and other reporting platforms to make research visible. These reports are then used to influence change among governments.

In contrast, Human Rights First (hereafter HRF) is a smaller NGO located in the United States, aimed at changing US foreign policy. HRF was founded in 1978 as the Lawyer Committee for Human Rights. It has three offices in New York, Washington DC, and Houston, with an operating budget of approximately \$4 million in 2014 (Human Rights First [HRF], 2014). HRF's early work centered on providing legal aid to refugees and asylum seekers, but later work expanded into lobbying the US government on human rights changes and foreign policy issues. HRF (n.d.) works toward "American ideals. Universal values." It touts the US history as a "beacon of human rights," hoping to use values such as equality and inclusivity to influence American policy.

\section{Method/Analysis}

This chapter uses a thematic analysis to examine refugee rights campaigns from HRW and HRF between 2016 and 2020. I collected campaign materials from HRW and HRF from January 1, 2016 to October 20, 2020. Specifically, I collected 581 press release, fact sheets, and reports from HRF. It is important to note that there is overlap between these distinctions by HRF, but they are all released under HRF's media banner. Similarly, I collected 795 reports, dispatches, news releases, and commentaries from HRW. Again, there is overlap distinguishing between reports, dispatches, letters, and commentaries published by HRW, but all are published under their news banner. It is also important to note that these materials often included additional links to reports or videos that were included in the analysis.

The chapter uses a hybrid approach to thematic analysis and incorporates both the data-driven inductive approach of Boyatzis (1998) and the 
deductive a priori template of a coded approach outlined by Crabtree and Miller (1999). Broadly, thematic analysis identifies, analyzes, and reports patterns and themes found in qualitative data (Boyatzis, 1998). An inductive approach is used to explore emergent themes from the data, and a deductive approach applies a preexisting frame to the data (Braun \& Clarke, 2006; Taylor, Bogdan, \& DeVault, 2015).

In this case, I developed a codebook based on Powers' (2017) normative theories of journalism. The four broad categories form the code manual include: expert, advocate, facilitator, and critic. Items were categorized based on the audience orientation (elites, laypeople, and social fringes) and news voice (impartial, advocative, deliberative/dialogic, and critical). I then further inductively explored emergent issues in the shifting and changing of these news roles. Fereday and Muir-Cochrane (2006) refer to this as secondorder coding, where a deductive approach applies a known framework to the data (first-order coding), and then a secondary inductive approach is used to explore emergent themes within the framework. The chapter prefaces that NGO journalistic norms and roles are shifting and hybridizing, highlighting four tensions: changes in the legitimation of NGO journalism, NGO audience engagement, new technologies in NGO journalism, and the emergence of the NGO critic.

\section{Acting as Experts: Changes in the Legitimation in NGO Journalism}

NGOs have long used news media as a tool to both spread awareness and gain legitimation. Although they have had difficulty gaining access (Jacobs \& Glass, 2002; Lang, 2013; Powers, 2018; Thrall, 2006; Trenz, 2004). However, Powers (2018) demonstrates that there has been at least a partial opening for NGOs over the last 20 years, allowing them to insert human rights frames into news stories. Gillmor (2014) explains that traditionally NGOs

did research, digging out documents, and interviewing people. They'd assemble what they collected into highly detailed reports, which they'd take to the major media that served as gatekeepers, and hope that a New York Times or 60 Minutes or other such organization would publish or broadcast a story that, they hoped, even more, would bring the public's attention to the topic. Or they'd hope to get an op-ed in the Times or the Washington Post, among other big outlets.

(para. 10)

In many ways, HRF and HRW still operate within this isomorphic template that relies on news organizations, particularly legacy media (newspapers, radio, and television), to promote their work and human rights agenda, maintaining roles as advocates and experts. HRF, for its part, utilizes media relationships to legitimize their human rights campaigns, to the extent that media relations are, in many ways, treated as partnerships between news 
journalists and political campaigns. Here, HRF relies on media to produce the news story, sending out press releases in hopes of receiving interest. In this sense, they maintain the role of expert, allowing news organizations to lead in story production.

They have had several recent successes. In 2019, HRF began collecting data from asylum seekers on the southern border, compiling a database of thousands of individuals under Migrant Protection Protocols (MPP). The database has subsequently been used in news reports from Mother Jones, NPR, and Buzzfeed. The database was recently mentioned in an episode of HBO's Last Week Tonight with John Oliver. The segment, which was later made available on YouTube, has been viewed by over 3.6 million people.

Comparatively, HRW has created its own internal journalism operations, hiring freelance photographers and journalists to write reports and stories, which allows HRW to control the message and manage its reputation. In a 2012 interview, Carroll Bogert, the deputy executive director for external relations at HRW, said, "We consciously ape the style of media in our communication in order that what we produce looks more like journalism" (Ellis, 2012). HRW stylistically uses Associated Press writing standards to make news releases look like standard new stories, including ledes and nut grafs. HRW goes further than merely mimicking news stories, but instead uses full-fledged media packages to send to news outlets. Media packages, which are standard practice in corporate public relations, include video features that are often supplemented material for television news broadcasts. These packages provide the whole video and disaggregated video, so media partners can more readily include content. In this regard, the hard work of news production is done solely by HRW. For example, HRW's video "Protect LGBT Asylum Seekers" is a three-minute video produced in a similar style to Vox or Vice News. It tells the story of Carlos, an asylum seeker from Honduras who was threatened by local gangs. The video features a voiceover from HRW researcher and LGBT rights expert Neela Ghoshal. The video is interspersed with clips from Carlos' phone of his journey across South America, as well as a sit-down interview. The professionalism of the video and subsequent transcripts makes the video package easy to slot into a television news segment. To this end, by stylistically following AP writing standards and mimicking the production style of Vox and Vice News, HRW asserts its role as expert. Moreover, the news story is careful to at the very least appear impartial rather than advocative. It merely explains Carlos' journey through video clips and interviews rather than exploring policy advocating a specific position. HRW is careful to maintain ethical precepts of factual reporting, thus maintaining their role as impartial experts (Reese, 2016 Schudson, 2011).

The relationship between HRW and HRF to news outlets has clearly shifted, potentially switching completely. As Fenton (2010) explains, news outlets largely rely on NGOs to provide news, in some cases, even produce it. As a result, there is a kind of reciprocal legitimation between the two 
NGOs. HRW and HRF gain access to the news outlet's audience, legitimating them as serious actors in the humanitarian sphere, a position that HRW has long occupied, but that is emergent for HRF. News outlets, meanwhile, gain well-researched and investigated news stories delivered without cost to their news organizations and legitimation with their viewers, many of whom favor NGOs as trusted news sources and political organizers (Castells, 2009; Lang, 2013).

NGOs long used new organizations to disseminate and legitimate their message, helping them maintain impartiality and creating their role as experts (Clark, 2001). But with international reporting declining and a pivot toward digital platforms (Abbott, 2009), HRW and HRF now act as legitimizers for news stories. Our conceptualization then of how an organization becomes and maintains their status as an expert is evolving. News organizations are now relying on their relationships with NGOs to appear as experts in international news reporting (Fenton, 2010). It is perhaps surprising then that a representative liberalism frame, which is a very particular kind of news tradition, is still maintained by NGOs that could perhaps benefit from alternative normative traditions. Of course, this does not mean that roles are not altering or hybridizing, but there is a clear parallel between the role of expert and perceived legitimation that should further be explored.

In their role as experts over the last few years, NGOs have subtly shifted the refugee frame used by news organizations, which traditionally link refugees and asylum seekers to increased crime and security risks (Rowe $\&$ O'Brien, 2014). The Trump administration's zero-tolerance policy that separated children from their family members provided an opportunity to push for attribution of blame and morality frames that place blame and condemn the Trump administration (Famulari, 2020). Consequently, news stories that denigrate state actions toward refugees and asylum seekers have helped create more favorable opinions of asylum seekers (Cooper et al. 2017). Summarily, NGOs were able to use their position as experts to create and disseminate impartial content that maintains stylistic norms but provides an alternative frame that benefits refugee campaigns.

\section{Experts and Advocates: Engaging the Audience in NGO Journalism}

NGOs prioritize coverage in mainstream media, specifically as a means to fundraise and appease donors, who value media coverage as a performance measurement (Benthall, 1993; Powers, 2015b). Additionally, political elites "value mainstream media coverage as a way to learn about advocacy demand" (Powers, 2018, p. 106). Although journalism traditions offer an array of audiences, elites and the general public are often targeted. When appealing to the general public, NGOs use mass media techniques to circulate news. News is also written or produced in an engaging way that makes it accessible to the layperson to increase awareness and understanding (Handley \& Chapman, 
2010). By appealing to the public or lay people, NGOs maintain a participatory democratic frame or advocative role.

NGOs appeal to the general public for three reasons. First, journalism draws attention and resources to an issue. Second, by making the public aware, laypeople engage with political elites about the issue. Third, gaining mass attention legitimizes the NGO and opens them to more fundraising opportunities to continue advocacy work. HRF has a clear commitment to engaging with the public and average layperson, thus maintaining their role as advocates. In their approach to campaigns, HRF (n.d.) explains:

[W] challenge the United States to respect its ideals, our goal is not to make a point but to make a difference-to get concrete results that have a tangible impact on people's lives. To that end, we conduct campaigns in pursuit of specific goals. And we urge you to participate in our campaigns so that policy makers in Washington hear from citizenchampions of human rights.

Perhaps the most exciting part of this statement is the emphasis on citizenchampions, which are meant to engage the political process and sway policymakers. This is a core tenet of participatory democracy that explains political participation is indispensable for the realization of a just society (Wolfe, 1986).

One of the most prominent features of the HRF's Refugees Renew America campaign is a series of videos and slides called "meet a refugee." The video is a personal interview with Sana, a Syrian refugee and activist. Additionally, the slides feature famous American refugees, including Mila Kunis, Madeleine Albright, Andy Garcia, and Albert Einstein. The videos and slides are meant to cast refugees as autonomous actors, making essential contributions to American society. The goal very clearly is to demonstrate how "refugees enrich American culture with unique skills and determination" (HRF, n.d.), inviting the layperson to embrace refugees and asylum seekers as significant community contributors. In this sense, HRF acts as advocates by embracing the layperson to emphasize a participatory democratic position.

The second audience are political elites and decision-makers. As Lang (2013) notes, the goal of all NGOs is to engage policymakers, often minimizing public interactions. Instead, mass audiences become a by-product rather than the intended audience. As Bogert, the executive director of external relations at HRW, explains, "We want to make sure we're occupying all the information channels flowing into the brain of a decision maker" (Ellis, 2012). Operating in a liberal representative tradition and maintaining their role as expert, the tradition favors elites and decision-makers as the targeted audience and often overlooks lay people's contribution to social change and policy work.

HRW has a long history of catering to elite audiences through journalism. The NGO actually commissioned a study of US policymakers' media habits to determine which news outlets they prefer-the New York Times and BBC 
(Powers, 2018). Further, HRW leverages its connections with journalists to push for news stories in prominent publications. Murrell (2014) explains that the Vulture Club, a closed Facebook group with over a thousand journalists and human rights professionals, arrange transportation, translation, and reporting needs among its members. Tim Heatherington, the prominent freelance journalist who often worked for Times and Human Rights Watch, was one such member. Essentially, HRW maintains its position as an expert to direct its messaging to elites, whom they perceive to be the more important audience over lay people or the social fringes.

Immigration policy is primarily an elite-led policy area, with little opportunity for input from civil society organizations, including NGOs (Statham \& Geddes, 2006). Although Ihlen, Figenschou, and Larsen's (2015) study of media strategies from NGOs and political elites in Norwegian immigration demonstrates that journalism can be a space to create a dialogue between the two sectors. HRW is particularly interested in engaging with political elites, as evidenced by their human rights agenda aimed at the 'next American president.' The publication targets ten key issues in the United States, including immigration and border policy. Here, HRW outlines three particular issues, including ensuring border policies that protect asylum seekers, the ending of detention centers and the protection of family units, and a cultural shift toward accountability in redressing those harmed by current US policy. Although the article is publicly available, the intended audience is clearly the Biden and Harris campaign that has publicly favored many of these immigration policy changes.

Although Human Rights First and Human Rights Watch prioritize different audiences, the layperson and political elites, each works toward the common goals of influencing US public opinion and immigration policy. The Trump administration's attack on US immigration, refugee, and asylum programs has been met with public horror at the images coming out of detention centers and harassment by ICE and border control officers. NGOs have seized on these events to reshape the public discourse toward refugees and asylum seekers. Although the Trump administration has continued in their pursuit of publicly persecuting these individuals, there has been a shift in public sentiment. A 2019 Pew Research Report reported 68\% of Americans were in support of taking in refugees fleeing violence and war, compared to $51 \%$ of Americans who believed the United States had a responsibility to accept refugees in 2018.

\section{Expanding the Role of Advocate: Engaging New Technologies in NGO Journalism}

In recent years, NGOs have turned to new digital tools and technologies to tell the story of refugees and asylum seekers. This has allowed American citizens to engage with and visually experience the life of a refugee through virtual platforms. HRF relies on legacy media formats, but also offers virtual reality videos to portray the asylum seekers' experience in an attempt to 
implement new technologies in their news storytelling. Meanwhile, HRW has created a partnership with the new media company, Upworthy, to gain traction for online viewership. Although this partnership has been met with mixed results, it has helped the NGO gain access to new outlets and larger audiences to promote its journalism. By engaging with new technologies and new media partnerships, HRW and HRF expand their communicative style and make their content more accessible to laypeople; in turn, this fulfills an advocative role and maintains a participatory democratic theoretical frame.

In April 2018, HRF paired with RYOT, a broadcast and media production company, to create a two-part virtual reality video series called Crossing the Line that "follows brave asylum seekers fleeing persecution who sought protection at the US southern border" (Human Rights First, 2018). The video is a 360-degree interactive video that allows viewers the experience of interaction between asylum seekers and US southern border patrol. Through a mixture of real-life interviews and bleak cartoon versions of border control interactions, the video follows Ancely, an asylum seeker fleeing with her child. At one point, she appears before a single border patrol agent, crying in agony, showing her arms wrapped in bandages, saying, "what do you want me to do, show you my cut off body parts?" (Human Rights First, 2018). Based on real-life accounts from over 125 cases collected by the HRF in their 2017 report Dangerous Territory: Mexico Still Not Safe for Refugees, viewers of the video experience the "catch and release" policy of the Trump administration.

It is video campaigns like this that shift HRF away from its more traditional press release strategy to engage with the public. Although jarring, the video attempts to engage in other communicative styles with the public to create more awareness about the crisis at the southern border. It is important to explain that an unintended consequence is that HRF gamifies the experience of refugees and asylum seekers. At times, the video reads more like a first-person video game than as a piece of journalism. However, news games have been shown to engage and create competency in viewers. Moreno, Wylie, and Serre-Delcor's (2019) work on refugee escape rooms demonstrate that these gamification tools raise awareness and increase intercultural competency. However, news games like this do not do an adequate job of creating a space for discourse (Plewe $\&$ Fürsich, 2018). At best, HRF begins to explore the role of advocate by developing alternative media that goes beyond a press release or simple news story. Instead, the visceral experience is clearly meant to shock but also advocate for social change in the refugee experience.

HRW, meanwhile, has become a tour de force in its use of new media technologies to leverage its journalism. Between 2009 and 2012, HRW won four Webby Awards for their in-depth reporting on human rights abuses. Moreover, it has turned its success into partnerships with other new media outlets like Upworthy. At the height of its success in November 2013, Upworthy was receiving 80 million viewers a month to its website (Karpf, 2016). They were known as the originator of the curiosity-gap headline, 
more affectionately known as clickbait. The "mission-driven media company" markets itself as a news curator. In its partnership with HRW, Upworthy gives news stories buzzy titles meant to drive foot traffic. For example, an HRW Story titled US: Immigrants Afraid to Call 911 was retitled by Upworthy as He called 911 when he needed help. He will always regret $i t$. Unfortunately, the partnership has floundered because shortly before it was announced, Facebook changed its feed algorithms, tanking Upworthy's viewership (Karpf, 2016).

Despite this disappointment, HRW robustly uses its website and Facebook presence to engage viewers. The NGOs reporting is prolific enough that news releases and reports flow directly to Google News alongside leading news organizations. A simple search for refugees on Google News brings up 25 million search results; of those, 248,000 either are reports from Human Rights Watch or include coverage from Human Rights Watch. The European Broadcasting Union has made video feeds from HRW available to its 85 broadcast members. Its YouTube page had over 33 million views in 2020, not accounting for its YouTube channels in other languages. Bogert, the external communications director of HRW, explains, "I think the question for us is what is the right balance between the short-form content that social media requires and the long-form content by which Human Rights Watch has made its name" (Ellis, 2012). In short, the use of digital technologies has dramatically expanded the reach of HRW, making their journalism more prominent.

The use of digital platforms and technologies to tell the story of refugees and asylum seekers represents participatory democratic traditions that favor the use of multiple communicative styles. Additionally, these platforms allow for systematic long-term campaigns that are meant to sustain social change. As Hunter, Van Wassenhove, and Besiou (2017, p. 10) find, "true reform and social change driven through media interventions are rarely the result of a single article, but are the result of sustained, long-term campaigns." Websites and social media also act as places to collect and curate the history of refugee rights campaigns, which is vital to the liberal representative tradition that favors a machine of record. Long and Saber (2020) argue that these archives of refugee accounts are a form of democratic practice. Refugee archives are a means to depict the conditions and circumstances of refugees showing those "who were forced to migrate, not in search of a better life, but simply in order to stay alive" (Saber \& Long, 2017 , p. 10). These records become vital to future diasporas built out of survivors, refugees, and asylum seekers (Marfleet, 2007, 2013, 2016). All too often, there is no official history of mass displacements, but digital technologies keep an automatic accounting, and NGO journalism helps perpetuate that story. New media forms are thus a space for the participatory democratic tradition and the liberal representative tradition, and NGOs are able to present as advocates through this communicative style, but they also present as experts due to the longevity and vast array reporting that is 
held on digital platforms. Here we see an adaptation or even hybridization of NGO roles.

\section{Hybridizing Normative Traditions: Embracing the Critic in NGO Journalism}

Historically, NGOs have relied on states to enact and enforce the human rights agenda. In Keck and Sikkink's (1998) boomerang model, NGOs rely on appeals to other states, NGOs, or international organizations to help them change the behaviors of another actor. Tarrow (2010) refers to this as transaction costs that politically constrain actors from developing more contentious politics that may uproot normative assumptions or change the humanitarian agenda. Powers (2018) contends that NGOs have eschewed the critic's role, in part because they often fail to criticize the root cause of problems. Moreover, Greenberg, Knight, and Westersund (2011) argue that NGOs' development of news norms helps them compete against wellresourced competitors for government and business resources, but this also stops them from using more radical forms of criticism (Fenton, 2010; Nash, 2008). However, among refugee rights activists, the relationship between the NGOs, news media, and the state has begun to shift as NGOs fight for refugee rights.

In a radical democratic perspective, Curan (2005) explains that NGOs are tasked to act as social critics, uprooting the status quo. Laclau and Mouffe (2001) clarify that in radical democratic traditions, political change works against neoliberal conceptions of democracy by expanding the definition of democracy beyond freedom and equality to include difference. However, in journalism, the radical democratic tradition of the critic's role is limiting because it restricts the role that NGOs have played in criticizing human rights abuses. Rather, a hybridized perspective still largely operates within the frames of representative liberalism and participatory democracy that uphold democratic institutions. Still, NGOs that hybridize and adapt normative journalism roles may account for the increased criticism we see against the state that treats refugees and asylum seekers as subhuman because of their status as non-citizens.

The humanitarian agenda has faced a systematic attack under the Trump administration, especially for refugees and asylum seekers. In response to this, NGOs have been more vocal in their abhorrence and disgust with Trump administration's policies. It should be noted that HRW and HRF's responses may appear more critical due to the Trump administration's numerous human rights abuses. Still, in part, these critiques have been uncharacteristic of the organizations, especially HRF that has traditionally relied on government aid for their work.

Under the Obama administration, HRF generally used a softer language when criticizing US immigration policy, using words like "decries," "gravely concerned," or "strongly urges" to demonstrate a sense of consternation 
with the US government. This language has grown harsher under the Trump administration. Additionally, their use of virtual reality videos, which is discussed previously in the chapter, has been used to highlight the atrocities asylum seekers experience due to the Trump administration's new policies, including kidnapping and mutilation. These efforts demonstrate a turn from HRF's role as an advocate based on their long-time commitment to providing legal aid to refugees and asylum seekers to that of a critic against democratic institutions the NGO has long upheld.

In October 2020, the Trump administration announced that they would cap the total number of admitted refugees to the United States at 15,000, the lowest on record (Human Rights First, 2020). In response, HRF published a statement damning the administration and accusing Trump of trying to "dismantle and destroy" resettlement and asylum systems. Eleanor Acer, the director of refugee protection, said:

This administration can always go lower... The administration is, once again, slamming the door on refugees in need of resettlement, just as it has slammed the door to refugees seeking asylum. Abandoning persecuted people in need of our protection reflects a total lack of moral and humanitarian leadership.

(Human Rights First, 2020, para. 3)

This is just one example of HRF statements that have been in objection to the Trump presidency. Resituating HRF's statements within the role of critic, we understand that these criticisms move beyond participatory or representative traditions. While the audience is still one of elites and laypeople, rather than the social fringes, the critic's role within these confines is to criticize an institutional system of which it is a member. In this sense, we see a clear hybridizing and adaptation of roles and journalistic traditions that bridge radical democratic roles with participatory and representative boundaries.

In a sense, Human Rights Watch has long lived within this gray area. They act as experts leveraging their own media production to news outlets, targeting key policymakers in the process. Although their reporting aligns with journalistic norms of transparency and accuracy, stylistically staying within the bounds of representative liberalism, HRW is not without a world perspective; this is to say that it is not impartial. Lang (2013) explains that because many freelance journalists are hired by NGOs and news outlets, they begin to reframe what "good" journalism looks like. She argues that these journalists often shift into advocates or critics without realizing their positioning. This is especially true of HRW's positioning on refugee rights. The lede from a dispatch in October 2020 reads, "US Should Immediately Repeal Border Orders Not Based on Public Health." Another news report from June of 2020 reads "US: Stop Using Untrained, Abusive Agencies at Protests," or a dispatch also from June 2020 that reads "Trump's 
Cold-Blooded Move to Shut Out Asylum Seekers.” These titles have a clear position that critiques the Trump administration and US immigration policy, going beyond advocate or expert.

To summarize, the role of the critic in NGO journalism has hybridized and adapted to fit within other journalism traditions. Rather than view the critic as absent from NGO journalism because it does not follow the expectations of radical democracy, we need to reorient expectations within the confines of current journalism standards. US journalism norms expect objectivity and a distinct lack of worldview, but this kind of neutrality or nonpartisanship is nearly impossible to practice (Calcutt \& Hammond, 2011). Rather, Herman and Chomsky have advanced a propaganda model that claims the notion of objectivity favors government viewpoints (Calcutt \& Hammond, 2011). As Christiane Amanpour, the famous CNN War Correspondent, explains, "neutrality can mean you are an accomplice to all sorts of evil" (Ricchiardi, 1996). The critic's role is especially important to refugees and asylum seekers that live outside or on the periphery of society. The critic's position is to spotlight these conditions and make them better through whatever means necessary. HRF and HRW are by no means representative of a radical democratic tradition. Still, they are critics of human rights abuses experienced by refugees and asylum seekers and are hybridizing their roles to spread awareness and influence policy that has a lasting impact.

\section{Conclusion}

The realities of what refugees and asylum seekers face at US borders are daunting. Human Rights Watch and Human Rights First are cases of two NGOs that work to document, investigate, and report on migration and refugee rights as a social justice issue. Through the use of NGO journalism, these organizations are raising public awareness and working to influence policymakers. This chapter has highlighted four trends within their NGO journalism on refugee matters: the shift in the relationships between NGOs and news organizations that now gain legitimation from one another; the continued focus on the general public or elites as target audiences to create awareness and social change; the use of digital platforms and technologies to create new news experiences and cast a wider publicity net; and the emergent role of the critic that has hybridized with other journalism traditions.

Using Powers (2017) normative journalism framework helps explore how NGOs shift, alter, and adapt aspects of one tradition or another to better suit their goals and strategy for impacting the human rights agenda. For example, we see that both HRW and HRF reside in an innocuous space where they can act as critics within the confines of representative liberalism and participatory democracy. Additionally, websites and other media platforms can act as alternative communicative styles reaching a wide audience acting within a representative liberalism frame, while also acting as an archive that legitimates their work and helps them reach expert status, thus 
working within a participatory democratic lens. What this framework also demonstrates is the clear lack of the facilitator role and calls for a discursive frame. This is particularly problematic in human rights areas with heavy norm contestation, like refugee rights.

The comparison between Human Rights Watch and Human Rights First draws into stark relief a series of trends affecting social change efforts among advocacy groups. In many cases, NGOs actively use similar digital strategies as corporations to draw attention to their advocacy and fundraising efforts. Media partnerships and collaborations have long acted as legitimizers for the public. Still, the proliferation and subsequent ubiquity of social media have changed the journalism strategies NGOs use to promote themselves in a hegemonic system of corporatization. Human Rights Watch partnership with Upworthy was a shift from the NGO's appeals to normative journalism standards to that of clickbait and buzzy titles meant to draw in foot traffic. Similarly, Human Rights First gamification of the refugee experience was a play to create a more interactive experience. In some ways, NGOs are now expected to use technologies like other corporations competing in the attention economy.

NGOs are more and more being pushed to embrace professionalism and corporatization at the expense of their advocacy, so there is a clear need to develop strategies that can balance that line. Using journalism as part of the communication strategy helps support policy and fundraising initiatives. Embracing alternative communicative styles such as video games, TikTok, memes, Twitter, etc. ensure that both elites and lay people see the news content. Additionally, alternative styles have been shown to increase empathy and global competency (Plewe \& Fürsich, 2018). NGOs should also work to embrace discursive and dialogic frames, embracing the facilitator role by presenting roundtables, editorial dialogues, or finding meaningful ways to embrace online comments sections. For example, work from Scacco, Muddiman, and Stroud (2016) found that including a respect button, rather than a like or recommend button in comment sections, decreased partisanship in political comments. There may be application for this in NGO comment sections. Finally, NGOs should question the role of impartiality in their reporting. This model of separation between journalism and activism is not widely understood outside a liberal Western model, and journalists themselves often critique impartiality. Instead, developing a consistent worldview that lends itself to goals and values of the organizations while maintaining truth and transparency can largely be achieved by including situational and historical context in reporting (Koch, 2018).

We have seen a clear adaptation of the critic role with that of advocate and expert. This shift is fundamental to NGOs' continued work, but particularly to the communities of refugees and asylum seekers. Attribution of blame frames that target the failures of governments to provide humane care and safety are particularly useful (Famulari, 2020). But NGOs must go farther in their pursuit of refugee rights. A 2020 report by the United Nations and 
World Meteorological Organization claims that climate change will quickly create new refugee crises as floods and droughts increase worldwide. Current immigration infrastructures are not prepared to cope with this influx, and while we work to solve the climate crisis, we must also be prepared to manage new refugees. In the coming days, NGOs will play a crucial part in creating these systems, but they must also be experts, advocates, facilitators, and critics of crises that come.

\section{References}

Abbott, K. (2009, November 9). Working together NGOs and journalists can create stronger international reporting. NiemanLab. Retrieved from https://www. niemanlab.org/2009/11/kimberly-abbott-working-together-ngos-and-journalistscan-create-stronger-international-reporting/

Barnett, T. L. (2020, February 9). Seventeen days with families seeking asylum on the border: Now is the time to break the cycle of violence. Retrieved from https://www.houstonchronicle.com/opinion/outlook/article/Seventeen-days-withfamilies-seeking-asylum-on-15039160.php

Benard, C. (1986). Politics and the refugee experience. Political Science Quarterly, 101(4), 617-636.

Benhabib, S. (2002). The claims of culture: Equality and diversity in the global era. Princeton, NJ: Princeton University Press.

Benson, R. (2008). Normative theories of journalism. In W. Donsbach (eds). The Blackwell International Encyclopedia of Communication. 2591-2597. New York: Blackwell.

Benthall, J. (1993). Disasters, Relief, \& the Media. London: I.B. Tauris.

Berkowitz, D. A., \& Liu, Z. (2014). The social-cultural construction of news. In R. S. Fortner \& P. M. Fackler (Eds.), The handbook of media and mass communication theory (pp. 301-313). Chichester, UK: John Wiley \& Sons Inc.

Bleiker, R. Campbell, D. Hutchison, E. \& Nicholson, X. (2013). The visual dehumanisation of refugees. Australian journal of political science, 48(4), 398-416.

Boyatzis, R. (1998). Transforming qualitative information: Thematic analysis and code development. Thousand Oaks, CA: Sage.

Braun, V., \& Clarke, V. (2006). Using thematic analysis in psychology. Qualitative research in psychology, 3(2), 77-101.

Calcutt, A. \& Hammond, P. (2011). Journalism studies: A critical introduction. New York: Routledge.

Castells, M. (2009) Communication power. New York: Oxford University Press.

Chadwick, A. (2017). The hybrid media system: Politics and power. Oxford, UK: Oxford University Press.

Chávez, K. R. (2012). The need to shift from a rhetoric of security to a rhetoric of militarization. Border rhetorics: Citizenship and identity on the US-Mexico frontier, Tuscaloosa, 48-64.

Christians, C. G., Glasser, T. McQuail, D. Nordenstreng, K. \& White, R. A. (2010). Normative theories of the media: Journalism in democratic societies. Urbana \& Chicago: University of Illinois Press.

Clark, A.M. (2001). Diplomacy of Conscience: Amnesty International and Changing Human Rights Norms. Princeton, NJ: Princeton University Press. 
Cooper, S., Olejniczak, E., Lenette, C., \& Smedley, C. (2017). Media coverage of refugees and asylum seekers in regional Australia: a critical discourse analysis. Media international Australia, 162(1), 78-89.

Cottle, S., \& Nolan, D. (2007). Global humanitarianism and the changing aid-media field: "Everyone was dying for footage". Journalism Studies, 8(6), 862-878.

Crabtree, B., \& Miller, W. (1999). A template approach to text analysis: Developing and using codebooks. In B. Crabtree \& W. Miller (Eds.), Doing qualitative research (pp. 163-177). Newbury Park, CA: Sage.

Curran, J. P. (2005). What democracy requires of the media. In G. Overholser \& K. Jamieson (Eds.), Institutions of American democracy: The press (pp. 120-140). New York: Oxford University Press.

Dewey, J. (1927). The public and its problems: An essay in political inquiry. University Park, PA: Pennsylvania State University Press.

Downing, J. (2001). Radical Media. Thousand Oaks, CA: Sage.

Ellis, J. (2012, September 2). How Human Rights Watch got into the quasi-journalism business. Retrieved from https://www.niemanlab.org/2012/09/how-human-rightswatch-got-into-the-quasi-journalism-business/

Famulari, U. (2020). Framing the Trump administration's “zero tolerance” policy: A quantitative content analysis of news stories and visuals in US news websites. Journalism studies, 1-18.

Fenton, N. (2010). New Media, Old News. London, UK: Sage.

Fereday, J., \& Muir-Cochrane, E. (2006). Demonstrating rigor using thematic analysis: A hybrid approach of inductive and deductive coding and theme development. International Journal of Qualitative Methods, 5(1), 80-92.

Ferree, M. M., Gamson, W. A., Rucht, D., \& Gerhards, J. (2002). Shaping abortion discourse: Democracy and the public sphere in Germany and the United States. Cambridge, MA: Cambridge University Press.

Flores, L. A. (2003). Constructing rhetorical borders: Peons, illegal aliens, and competing narratives of immigration. Critical Studies in Media Communication, 20(4), 362-387.

Freedman, J. (2010). Protecting women asylum seekers and refugees: From international norms to national protection? International migration, 48(1), 175-198.

Frelick,B.(2020, October 21).US,Australia hit new lows on refugee resettlement. Human Rights Watch. Retrieved from https://www.hrw.org/news/2020/10/21/us-australiahit-new-lows-refugee-resettlement\#: :text=The $\% 2011 \% 2 \mathrm{C} 814 \% 20$ refugees $\%$ 20 admitted $\%$ 20to, $85 \% 2$ C000\%20admitted $\% 20$ in $\% 20 F Y \% 202016 . \&$ text $=$ Yet $\% 20$ in \%20the \%20fiscal\%20year,percent \%20drop \%20from \%20FY\% 20 2016.

Gans, H. (2003). Democracy and the news. New York: Oxford University Press.

Gastil, J. (2008). Political communication and deliberation. Thousand Oaks, CA: Sage.

Greenberg, J. Knight, G. \& Westersund, E. (2011). Spinning climate change: Corporate and NGO public relations strategies in Canada and the United States. International Communication Gazette, 73(1-2), 65-82.

Gillmor, D. (2014, March 28). In praise of the almost-journalists. Retrieved from https://www.unhcr.org/globaltrends2019/ https://slate.com/technology/2014/03/ human-rights-watch-and-other-advocacy-groups-doing-great-journalism.html

Handley, A., \& Chapman, C. C. (2010). Content rules: How to create killer blogs, podcasts, videos, ebooks, webinars (and more) that engage customers and ignite your business (Vol. 5). Hoboken, NJ: John Wiley \& Sons. 
Hall, N. (2019a). When do refugees matter? The importance of issue salience for digital advocacy organizations. Interest Groups \& Advocacy, 8(3), 333-355.

Hall, N. (2019b). Norm contestation in the digital era: campaigning for refugee rights. International Affairs, 95(3), 575-595.

Hertel, S. (2006). Unexpected power: Conflict and change among transnational activists. Ithica, NY: Cornell University Press.

Human Rights First. (n.d.). About Us. Retrieved from https://www.humanrightsfirst. org/about.

Human Rights First (n.d.). Campaigns. Retrieved from https://www.humanrightsfirst. org/ campaigns

Human Rights First (2018, April 11) Crossing the Line: Untold stories of refugees stuck at the border. Retrieved from https://www.facebook.com/humanrightsfirst/ videos/2095206963826257

Human Rights First (2020, October 1). Human Rights First statement on historically low refugee admittance. Retrieved from https:/www.humanrightsfirst.org/ press-release/human-rights-first-statement-historically-low-refugee-admittance

Human Rights First. (2014). Human Rights First financial statement. Retrieved from http://www.humanrightsfirst.org/uploads/pdfs/HRF-2014-audited-financials.pdf

Human Rights First (2018, April 11). New virtual reality video highlights challenges refugee families face at southern border. Retrieved from https://www.humanrightsfirst. org/press-release/new-virtual-reality-video-highlights-challenges-refugee-familiesface-southern-border

Human Rights First (n.d.) Refugees renew America. Retrieved from https://www. humanrightsfirst.org/campaigns/refugees-renew-america

Human Rights Watch. (2017). Human Rights Watch history. Retrieved from https:// www.hrw.org/history.

Human Rights Watch (2020, October 6). Protect LGBT asylum seekers. Retrieved from https://www.hrw.org/video-photos/video/2020/10/06/376624

Hunter, M. L., Van Wassenhove, L. N., \& Besiou, M. (2017). Power is everywhere: How stakeholder-driven media build the future of watchdog news. The Stakeholder media project. Retrieved from https://www.researchgate.net/publication/ 321316410_Power_is_Everywhere_How_stakeholder-driven_media_build_the_ future_of_watchdog_news

Ihlen, Ø., Figenschou, T. U., \& Larsen, A. G. (2015). Behind the framing scenes: Challenges and opportunities for NGOs and authorities framing irregular immigration. American behavioral scientist, 59(7), 822-838. Doi: 10.1177/0002764215573254

Jacobs, R. N., \& Glass, D. J. (2002). Media publicity and the voluntary sector: The case of nonprofit organizations in New York City. Voluntas: International journal of voluntary and nonprofit organizations, 13(3), 235-252.

Karpf, D. (2016). Analytic activism: Digital listening and the new political strategy. New York: Oxford University Press.

Keck, M., \& Sikkink, K. (1998). Activists beyond borders: Advocacy networks in international politics. Ithica, NY: Cornell University Press.

Koch, A. (Feb 2, 2018) How journalists, NGOs can-- \& -- should collaborate. Global Investigative Journalism Network. Retrieved from https://gijn.org/2018/02/02/ investigative-journalists-ngos-can-work-together/

Laclau, E., \& Mouffe, C. (2001). Hegemony and socialist strategy: Towards a radical democratic politics. Verso.

Lang, S. (2013). NGOs, civil society, and the public sphere. New York: Cambridge University Press. 


\section{Delaney Harness}

Lippman, W. (1922). Public Opinion. New York: Macmillan.

Long, P., \& Saber, D. (2020). Refugee writing, refugee history: Locating the refugee archive in the making of a history of the Syrian war. In Refugee imaginaries: Research across the humanities (pp. 444-462). Edinburgh: Edinburgh University Press.

Lück, J., Wozniak, A. \& Wessler, H. (2016). Networks of coproduction: How journalists and environmental NGOs create common interpretations of the UN climate change conferences. The International Journal of Press/Politics, 21(1), 25-47.

Marfleet, P. (2007). Refugees and history: Why we must address the past. Refugee survey quarterly, 26(3), 136-148.

Marfleet, P. (2013). Explorations in a foreign land: States, refugees, and the problem of history. Refugee Survey Quarterly, 32(2), 14-34.

Marfleet, P. (2016). Displacements of memory. Refuge: Canada's Journal on Refugees, 32(1), 7-17.

McKay, F. H., Thomas, S. L., \& Kneebone, S. (2012). It would be okay if they came through the proper channels: Community perceptions and attitudes toward asylum seekers in Australia. Journal of Refugee Studies, 25(1), 113-133.

McNair, B. (2000). Journalism and democracy. London, UK: Routledge.

McPherson, E. (2015). Advocacy organizations' evaluation of social media information for NGO journalism: The evidence and engagement models. American Behavioral Scientist, 59(1), 124-148.

Moreno, N., Wylie, L., \& Serre-Delcor, N. (2019). Refugee escape room@: A new gamification tool to deepen learning about Migration and Health. European Journal of Public Health, 29(4). https://doi.org/10.1093/eurpub/ckz185.248

Murrell, C. (2014). The vulture club: International newsgathering via Facebook. Australian Journalism Review, 36(1), 15-27.

Nash, K. (2008). Global citizenship as show business: The cultural politics of make poverty history. Media, Culture \& Society, 30(2), 167-181.

Ono, K. A., \& Sloop, J. M. (2002). Shifting borders: Rhetoric, immigration, and California's proposition 187 (Vol. 15). Philadelphia, PA: Temple University Press.

Pedersen, A., \& Hartley, L. K. (2015). Can we make a difference? Prejudice towards asylum seekers in Australia and the effectiveness of antiprejudice interventions. Journal of Pacific Rim Psychology, 9(1), 1-14.

Phillips, N., \& Hardy, C. (1997). Managing multiple identities: Discourse, legitimacy and resources in the UK refugee system. Organization, 4(2), 159-185.

Phillips, J. \& Spinks, H. (2013). Immigration detention in Australia. Department of Parliamentary Services, Parliamentary Library.

Plewe, C. \& Fürsich, E. (2018). Are newsgames better journalism? Empathy, information and representation in games on refugees and migrants. Journalism Studies, 19(16), 2470-2487.

Powers, M. (2015a). Opening the news gates? Humanitarian and human rights NGOs in the US news media, 1990-2010. Media, Culture of Society, 38(3), 315-331.

Powers, M. (2015b). The new boots on the ground: NGOs in the changing landscape of international news. Journalism, 17(4), 401-416.

Powers, M. (2017). Beyond boon or bane: Using normative theories to evaluate the newsmaking efforts of NGOs. Journalism studies, 18(9), 1070-1086. https://doi. org/10.1080/1461670X.2015.1124733

Powers, M. (2018). NGOs as Newsmakers: The Changing landscape of international news. New York: Columbia University Press. 
Ramos, H., Ron, J., \& Thoms, O. N. (2007). Shaping the northern media's human rights coverage, 1986-2000. Journal of Peace Research, 44(4), 385-406.

Reese, S. D. (2016). The new geography of journalism research: Levels and spaces. Digital Journalism, 4(7), 816-826.

Ricchiardi, S. (1996). Over the line?. American Journalism Review, 18(7), 24-31.

Ron, J., Ramos, H. \& Rodgers, K. (2005). Transnational information politics: NGO human rights reporting, 1986-2000. International Studies Quarterly, 49(3), 557-587.

Rowe, E., \& O’Brien, E. (2014). 'Genuine' refugees or illegitimate 'boat people': Political constructions of asylum seekers and refugees in the Malaysia Deal debate. Australian Journal of Social Issues, 49(2), 171-193.

Russell, A. (2013). Innovation in hybrid spaces: 2011 UN climate summit and the expanding journalism landscape. Journalism, 14(7), 904-920.

Saber, D. \& Long, P. (2017). 'I will not leave, my freedom is more precious than my blood'. From affect to precarity: crowd-sourced citizen archives as memories of the Syrian war. Archives and records, 38(1), 80-99.

Schemer, C. (2012). The influence of news media on stereotypic attitudes toward immigrants in a political campaign. Journal of Communication, 62(5), 739-757.

Schudson, M. (2008). Why democracies need an unlovable press. Cambridge, UK: Polity.

Scribner, T. (2017). You are not welcome here anymore: restoring support for refugee resettlement in the age of Trump. Journal on Migration and Human Security, 5(2), 263-284.

Selsky, A. \& Whittle, P. (2019, June 16). Record number of African migrants coming to Mexico border. Associated Press News. Retrieved from https://apnews.com/art icle/429f04067c38428ba0d06749b53e6df0

Statham, P., \& Geddes, A. (2006). Elites and the 'organised public': Who drives British immigration politics and in which direction? West European Politics, 29(2), 248-269.

Scacco, J. M., Muddiman, A., \& Stroud, N. J. (2016). The influence of online quizzes on the acquisition of public affairs knowledge. Journal of Information Technology \& Politics, 13(4), 311-325.

Tarrow, S. (2010). Outsiders inside and insiders outside: linking transnational and domestic public action for human rights. Human Rights Review, 11(2), 171-182.

Taylor, S. J., Bogdan, R., \& DeVault, M. (2015). Introduction to qualitative research methods: A guidebook and resource (4th edition). Hoboken, NJ: John Wiley \& Sons.

Thrall, T. (2006). The myth of the outside strategy: Mass media news coverage of interest groups. Political Communication, 23(4), 407-420.

Thrall, T., Stecula, D., \& Sweet, D. (2014) May we have your attention please? Human-rights NGOs and the problem of global communication. The International Journal of Press/Politics, 19(2), 135-139.

Trenz, H. J. (2004). Media coverage on European governance: Exploring the European public sphere in national quality newspapers. European Journal of Communication, 19(3), 291-319.

United Nations High Commission on Refugees (2019) Global trend: Forced displacement in 2019. Retrieved from https://www.unhcr.org/globaltrends2019/.

Van Gorp, B. (2005). Where is the frame? Victims and intruders in the Belgian press coverage of the asylum issue. European Journal of Communication, 20(4), 484-507. 


\section{Delaney Harness}

Wang, H. (2012). Immigration in America: library services and information resources. Reference Services Review, 40(3), 480-511.

Wasik, L.F. (2013, November 7). How to choose a charity wisely. The New York Times. Retrieved from https://www.nytimes.com/2013/11/08/giving/how-to-choose-acharity-wisely.html

Wolfe, J. D. (1986). Varieties of participatory democracy and democratic theory. The Political Science Reviewer, 16, 1-38.

Wright, K. (2016). Moral economies: Interrogating the interactions of NGOs, journalists and freelancers. International Journal of Communication, 10, 1510-1529. Yanacopulos, H. (2015). International NGO engagement, advocacy, activism: The faces and spaces of change. New York: Springer. 


\title{
4 Integrating Social Media in NGO Strategic Communication
}

\author{
Lessons From Dutch NGOs' \\ Communication Practices
}

\section{Delia Dumitrica}

The adoption of social media by non-governmental organizations (hereafter NGOs) has been praised as a low-cost yet impactful communication strategy to engage different publics and stakeholders, from funders and volunteers to the wider public opinion. However, most current empirical research on NGO social media uses in the field of public relations (PR) focuses on select channels, with little attention to how they intersect and become integrated into the organization's larger communication ecosystem. This chapter argues that the integration of social media in NGO strategic communication should be addressed in a more holistic manner, addressing recent prompts to consider social media adoption in relation to organizational strategies, governance, and contextual environment (Janssen Danyi \& Chaudhri, 2018; Nah \& Saxton, 2013; Saxton \& Guo, 2014). To exemplify this approach, this chapter presents an exploratory study of social media use by Dutch social change NGOs working in areas such as social justice, environmentalism, LGBTQ rights, refugees, literacy, and participatory democracy.

Methodologically, the study juxtaposes a content analysis of social media with findings from ten in-depth interviews with NGO representatives. Where content analysis can provide insights into how NGOs use specific social media channels to communicate with their publics and stakeholders, interviews are able to place the adoption of new platforms into the wider communication strategy of an organization, shedding light on factors influencing this adoption. This triangulated approach reveals that social change NGOs in the Netherlands deploy a mix of traditional and new media channels in an effort to adapt to the shifting practices of the larger communication ecosystem. Importantly, some channels such as email newsletters, leaflets, or advertising can remain invisible when researchers focus exclusively on the online presence of an organization. The chapter recommends that the study of social media in NGOs' strategic communication should be approached as in flux, shaped by context-specific factors such as the availability of human and financial resources, collaborations, mission, etc. and inserted within the larger, multichannel communication practices of the organization. This approach affords more nuanced insights into the strategic communication practices of NGO social change initiatives.

DOI: $10.4324 / 9781003188636-6$ 


\section{NGO's Social Media Use: The Public Relations Approach}

NGOs refer to organizations with a legal status that is mainly characterized by their nonprofit and voluntary orientation, thus making these organizations distinct from the government and the corporate sector (Ricciutti \& Caló, 2018). Furthermore, social change NGOs are animated by a desire to transform civil society in a democratic and often participatory manner. This means they engage various publics, from journalists or funders to (potential) volunteers or the public at large. Communication processes-both external and internal to the organization-thus lie at the heart of an NGO's social change strategy. Regardless of mission or size, NGOs have to be attuned to general communication practices within their particular environment (Campbell \& Lambright, 2018).

In the field of PR, the integration of new media in NGOs' communication practices has been placed under the banner of dialogue and interactivity (Taylor \& Kent, 2014), promising the development of a new culture based on technologically mediated "engagement, participation and dialogue" (Greenberg \& MacAulay, 2009, p. 67). NGOs' subsequent adoption of social media was largely assessed through the same dialogical lens. Several studies examined the use of one or two social media channels in order to identify the presence and potential of two-way communication with different types of publics (Auger, 2013; Bortree \& Seltzer, 2009; Edwards \& Hoefer, 2010; Inauen \& Schoeneborn, 2014; Kim et al., 2014; Lovejoy et al., 2012; Lovejoy \& Saxton, 2012; Namisango \& Kang, 2019; Waters \& Jamal, 2011; Waters et al., 2009). Lovejoy and Saxton's (2012) typology of functions of social media communication-inform, build, and maintain community and mobilize publics for action-provided a subsequent framework for further analysis of the integration of these channels into NGOs' communication practices. Overall, the findings of the dialogical approach have highlighted that organizations tend to use these channels in a broadcasting manner, to promote themselves or inform publics of their activities.

A second relevant approach in the PR study of social media use by NGOs examines the factors influencing technological adoption. Informed by resource dependence theories, such studies seek to identify (mostly via surveys) the organizational dimensions conducive to the adoption and effective (i.e., dialogical) use of social media (Adjei et al., 2016; Nah \& Saxton, 2013; Seo et al., 2009; Svensson \& Hambrick, 2015). In general, findings suggest that new media adoption hinges upon the presence of a dedicated communication and marketing team within NGOs.

One limitation of the public relations literature is the tendency to decontextualize the use of a social media channel and examine it as if it were the only communicational tool of the organization. The (relatively easy) access to an organization's online presence, along with the simple coding tool provided by Lovejoy and Saxton (2012), have boosted the popularity of content analyses in the study of NGOs' use of social media. Yet, in 
practice, NGOs juggle multiple online and offline channels to communicate with their audiences. Different channels are seen as more appropriate for reaching out to different publics (Auger, 2013; Guidry et al., 2017; Kim et al., 2014). This suggests the need for a more holistic approach to address the relation between new communication technologies such as social media and an organization's communication needs, strategy, and practices.

\section{From Social Media Channels to the Communication Ecosystem}

To outline such a holistic approach, this chapter draws inspiration from the related field of grassroots collective action, as this field has adopted a more comprehensive view to the communication strategy deployed by citizens and NGOs involved in civic mobilization processes. Such research has revealed that, in practice, such communication strategies rely upon a mix of new and old media that reflects the wider hybrid media system within which they operate (Chadwick, 2013; Treré, 2018). Citizen mobilizers and NGOs alike often switch between channels, while each channel can fulfill different communicational and organizational roles. For example, email can be a means of information (both internally, among staff, and externally, with other stakeholders) and a means of decision-making (where feedback thus received cements the action the organization will take). Thus, communication strategies in grassroots collective action have to remain fluid, changing with the life cycle of the mobilization process and the type of action performed (Mattoni \& Treré 2014).

Furthermore, in hybrid media systems, social actors have to constantly mediate between the pressure to adapt to the medium's logic and the need to appropriate the medium for their own purposes. Blending remains a keyword in this process: different messages, media, and practices of use are mixed and adapted to different goals and forms of action (Morell, 2012). Thus, communication strategies develop within a larger communication ecology or ecosystem (Bastos et al., 2015; Mattoni, 2017; Mattoni \& Treré, 2014; Treré \& Mattoni, 2016). The terms “ecology" and "ecosystem” point to the interrelation "among social activities, information technologies, and communication formats" (Treré \& Mattoni 2016, p. 294). In its dictionary version, ecosystem refers to "the complex of living organisms, their physical environment, and their interrelationships in a particular unit of space" (Encyclopædia Britannica, 2019). When borrowed in the discussion of communication media, the term thus evokes the idea of a complex system with interrelated elements.

Adopting an ecosystem approach to NGOs' social media use can thus address calls to the communication mix in relation to organizational strategies, governance, and contextual environment (Janssen Danyi \& Chaudhri, 2018; Nah \& Saxton, 2013; Saxton \& Guo, 2014). Even though not all NGOs share the mobilizing aim of collective action, communication with different publics remains at the heart of their activities. Starting from the 
assumption of an NGO's communication as an ecosystem orients research toward capturing the "communicative complexity" (Treré \& Mattoni, 2016, p. 301) within and outside of the NGO, eschewing dichotomies such as online/offline, new/old (media). Furthermore, such an approach entails a sensitivity to multiple media formats and fluid media practices within the organization as well as between the organization and its multiple stakeholders (Mattoni \& Treré, 2014).

\section{The Dutch NGO Sector: An Overview}

To illustrate the ecosystem approach, this chapter builds on an exploratory study of the adoption of social media by Dutch social change NGOs. In the Netherlands, this sector has had a rich tradition of social welfare delivery, being among the largest in the world (Brandsen \& Pape 2015; Burger \& Veldheer, 2001; Burger et al, 1999; Schulpen, 2016). Referred to as the "societal midfield" (van Doorn quoted in Brandsen \& Pape, 2015), Dutch NGOs remain generally focused on service delivery in areas such as education, health, or social housing (Burger \& Veldheer, 2001). In turn, such organizations have enjoyed dedicated public funding-although this has tended to benefit larger organizations in the field of aid and development, such as Oxfram Novib, ICCO, Hivos, or Cordaid. Between the 1960s and 1990s, these large organizations have received a fixed percentage of Dutch public international aid (Koch \& Loman, 2009). Smaller NGOs, on the other hand, had to tap into smaller and more fragmented public funding schemes.

The neoliberal policy turn (1980s-1990s) in the Netherlands has also affected NGOs, pressuring them to adopt a "managerial" ethos and to look for private funding (Koch \& Loman, 2009; Brandsen \& Pape, 2015; Schulpen, 2016). As a result, "many nonprofit organizations were forced to reorganize, professionalize, merge, or commercialize" (Burger \& Veldheer, 2001, p. 227). Furthermore, under the banner of terms such as "active citizenship" and "do-democracy," the government coupled administrative decentralization and the retreat of the welfare state with the promotion of volunteerism as a sign of "good citizenship" (Verhoeven \& Tonkens, 2013).

Today, NGOs remain a substantial sector of the Dutch economy. In addition to public funds, corporations now provide around $60 \%$ of the revenues of the Dutch NGO sector, although this tends to favor specific sectors like sports and recreation (Meijer et al., 2006). In addition, around 87\% of Dutch households donate to the NGO sector (primarily health, environment, and international aid), both financially and in-kind (Bekkers et al., 2015; Schuyt et al., 2013; Ugur, 2018). National donation campaigns have a long-standing history (Wiepking $\&$ van Leeuwven, 2013), while door-todoor solicitations remain the most popular way of donating, although online and text messaging donations are also growing (Bekkers et al., 2015).

Such studies of Dutch NGOs however rarely focus on communication processes. This chapter thus takes an exploratory approach to this problematic, 
building upon existing studies suggesting organizations are likely to rely upon different media channels during campaign periods, while broadcasting remains crucial to their communication practices. This is not surprising, as the Dutch media system is characterized by the prominence of broadcasting as a source of news (Reuters Institute, 2018), which is echoed by a handful of empirical studies on digital activism (Bekkers et al., 2011; Dumitrica \& Achterberg, 2017). When it comes to social media use, Dutch NGOs tend to associate these channels with collaboration, as a means to connect and interact with their publics. Yet, NGOs also struggle with implementing social media into their overall communication programs (Sheombar et al., 2015).

\section{Methodology}

The chapter builds upon interviews with and content analysis of ten social change NGOs in the Netherlands. The organizations were identified by consulting two government publications (Burger \& Dekker 2001; Gemeente Den Haag, 2013). The sample was heterogeneous in type of organization, specialization, geographical scope, and history (see Table 4.1). While small, the sample enabled an exploratory mapping of social media use by Dutch NGOs.

The interviews were conducted between 2015 and 2018, seven by phone and three in person (for one NGO, we interviewed two different members). Interviewees were involved in organizational communication, in roles such as social media officer, PR officer, or communication advisor. The interviews lasted between one and two hours. Introduced as an inquiry into social media use by Dutch NGOs, each interview started with questions about the history of the respective organization and its main programs. The next section focused on the use of social media, with particular attention to the NGO's relation with various stakeholders-such as journalists, politicians, or volunteers. Finally, respondents were asked their opinion about the advantages and disadvantages of social media use in their NGOs. Importantly, participants were asked to connect social media use to the larger communication infrastructure of the organization.

In response to the public relations literature reviewed earlier, a content analysis of the NGOs' online presence was added. The analysis, focused on the interactive elements of websites and social media channels, was done independent of the interviews, in order to allow comparisons between the findings obtained through each of the two data collection methods. This stage of the analysis thus started from the NGOs' websites, moving along to the other public online communication channels linked from there. For websites, the analysis captured the structure of the homepage, with attention to the presence of interactive elements (e.g., opinion poll, donate button) and social media icons. For the social media channels, the analysis recorded the metrics made available by the platform, along with elements such as latest content (e.g., latest uploaded video on YouTube, number of Facebook posts in the last month). 
Table 4.1 Dutch NGOs interviewed in this project

\begin{tabular}{|c|c|c|c|c|c|}
\hline & Type & Specialization & Geographical scope & Founded & Respondent Pseudonym \\
\hline Meer Democratie & Nonprofit & $\begin{array}{r}\text { Participatory } \\
\text { democracy }\end{array}$ & National & 2015 & Respondent 1 \\
\hline $\begin{array}{l}\text { Transnational } \\
\text { Institute }\end{array}$ & $\begin{array}{l}\text { Nonprofit research and advo- } \\
\text { cacy institute }\end{array}$ & Social justice & International & 1974 & Respondent 2 \\
\hline Stichting Petities & Nonprofit & $\begin{array}{l}\text { Participatory } \\
\text { democracy }\end{array}$ & National & 2004 & Respondent 3 \\
\hline Ons Geld Stichting & $\begin{array}{l}\text { Nonprofit organization } \\
\text { associated with a citizen } \\
\text { initiative }\end{array}$ & Economic change & National & 2013 & $\begin{array}{l}\text { Respondent } 4 \\
\text { Respondent } 5\end{array}$ \\
\hline Milieudefensie & $\begin{array}{l}\text { Nonprofit association with } \\
55,000 \text { members }\end{array}$ & Environment & National & 1971 & Respondent 6 \\
\hline $\begin{array}{l}\text { Federatie } \\
\quad \text { Broekpolder }\end{array}$ & Community-based nonprofit & Environment & Local & 2006 & Respondent 7 \\
\hline COC Nederland & Federation of nonprofits & LGBTQ & $\begin{array}{l}\text { National/ } \\
\text { international }\end{array}$ & 1946 & Respondent 8 \\
\hline $\begin{array}{l}\text { Stichting Lezen and } \\
\text { Schrijven }\end{array}$ & Nonprofit & Literacy & National & 2006 & Respondent 9 \\
\hline Stichting Vluegeling & $\begin{array}{l}\text { Emergency relief fund } \\
\text { (nonprofit) }\end{array}$ & $\begin{array}{l}\text { Conflict areas and } \\
\text { refugees }\end{array}$ & $\begin{array}{l}\text { National/ } \\
\text { international }\end{array}$ & 1956 & Respondent 10 \\
\hline
\end{tabular}




\section{From Social Media Use to Mapping Communication Ecosystems}

In PR research, NGOs' use of social media is often examined in terms of the organization's ability to shift from one- to two-way communication. One-way communication refers to the use of communication technologies to broadcast a social actor's idea or plans. The features of web 2.0-namely, "openness for collaboration and interactivity" and "a requirement for authenticity instead of pre-packaged imagery and content" (Macnamara, 2010, pp. 26-27)—recommend new forms of communication and sociality based upon dialogue and interaction. Two-way communication is seen as leading to relationship and community-building, and thus more desirable for engaging an organization's stakeholders (Cho et al. 2014; Harrison et al., 2017).

In line with the two-way communication paradigm, the content analysis revealed that the ten Dutch social change NGOs seamlessly blended different channels within existing websites. All homepages featured social media icons, alongside tools such as newsletter subscriptions, donation or membership buttons, or, in a few cases, opinion polls and even a quiz. At a bare minimum, the online communication ecosystem of organizationsregardless of scope or size-used a website, a Facebook page, and a Twitter account. Recent trends of favoring visuals over text online were also reflected here, both in terms of using still and moving images in websites and on social media accounts and in terms of experimenting with Instagram and/ or YouTube accounts (Guo \& Saxton, 2018; Saxton \& Waters, 2014). One organization used podcasts, one had a blog, two offered RRS (or web) feeds (however, these did not seem to work), and three had LinkedIn accounts. Overall, however, Facebook remained the most popular social media platform in terms of numbers of followers (Figure 4.1).

This blending of the different channels was also visible on the social media accounts of these organizations. While NGOs may use each channel for a different strategic purpose such as community-building, information provision, or calls to action (Auger, 2013; Guidry et al., 2017), cross-promotion of the same content can amplify reach and strengthen brand identity. The Dutch NGOs in this study circulated virtually the same content across these different social media channels. Facebook posts and tweets mirrored each other, providing links to the website that hosted longer versions of the messages. YouTube videos and Instagram photos were also recycled in websites, Facebook, and Twitter posts.

Understanding why this happened and how it fit with the organization's overall strategic communication was however difficult to establish on the basis of a content analysis alone. The interviews, however, placed social media use within the organization's communication ecosystem. Similar to Chadwick's (2013) argument that organizations adapt to a hybrid media system, the respondents in this study painted a picture of complementarity and multifunctionality of the different communication channels used 


\section{Social media followers across the sample}

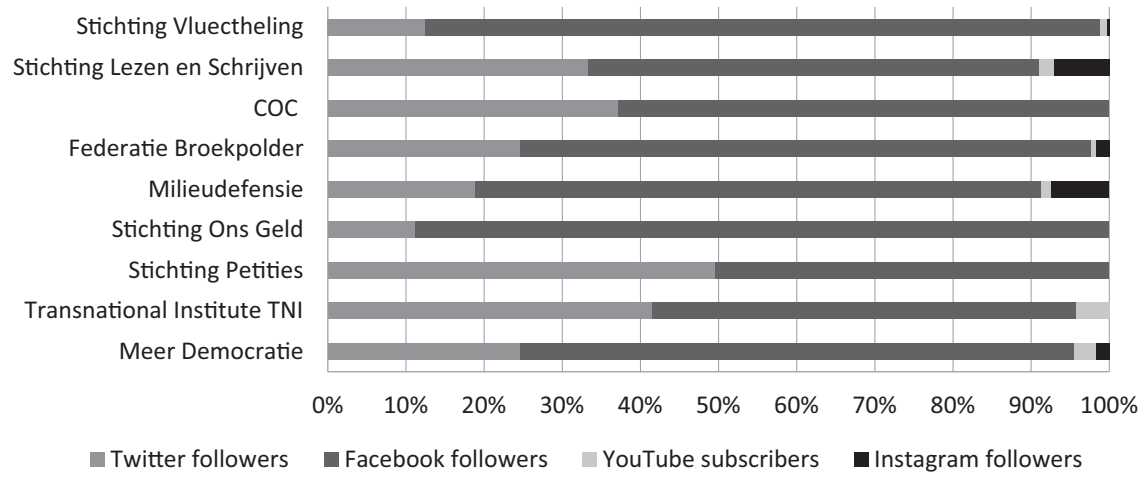

Figure 4.1 Social media followers across the sample.

Note: Federatie Broekpolder uses Flickr, not Instagram.

in their respective social change NGOs. The interviews thus revealed organizations' reliance on communication channels not captured by the (albeit limited) content analysis performed here-such as e-newsletters, leaflets, or even telephone calls. In the Dutch context, they foregrounded the NGOs' ongoing reliance on offline communication, mass media amplification, and advertising in addition to their online communication ecosystem. Furthermore, the interviews also added context on factors shaping the integration of (new) social media channels in existing communicational practices: resource availability, the organization's own mission and goals, and the communication preferences of the multiple publics and stakeholders that organizations serviced.

\section{Offline Communication Still Matters}

Even though the focus of the study was on social media use, it turned out that offline communication remained important in one way or another for almost all of the organizations in the sample. Such offline communication can often disappear from sight in studies focused on an organization's use of a specific social media platform like Twitter or Facebook. In the case of the Dutch NGO employees interviewed here, lobbying and advocacy, personal contacts and face-to-face discussions with politicians and policymakers, and physical events were seen as a crucial part of the organization's strategic communication. For Federatie Broekpolder-a small community association born out of the desire to protect a recreational area-the volunteer tent in the recreational area was a central site of recruiting volunteers. In 
other cases, although not asked specifically about offline means of communication, respondents spontaneously defined telephone calls, letters, fliers, brochures, or posters as their most used communication channels in their NGOs, highlighting the importance of analogue communication channels in managing the relation with various types of stakeholders. Fliers and brochures, for instance, were used in face-to-face events. Particularly in the case of organizations dealing with social groups less likely to engage in extensive use of online channels, telephone and letters were still widely used. Respondent 7 (Federatie Broekpolder) explained: "[W]e also have a public that is a bit older and don't have [access to] a website or social media, although that is decreasing, of course.”

\section{The Benefits of Mass Media Coverage}

In addition to this reliance on a mix of online and offline communication channels, all social change NGOs spoke of the crucial amplification role that mass media provided them. NGOs often "face an uphill and uneven struggle for publicity" (Powers, 2015, p. 434). This may motivate them to pursue good relations with journalists, but also to their online communication ecosystem to "become their own news providers" (Powers, 2015, p. 434).

In the case of the Dutch NGOs in this study, obtaining media coverage was an important status-marker, as well as a boost in the number of stakeholders. All NGOs sought to cultivate relationships with journalists, often by phone or by email, and sent press releases regularly. Twitter, the website, and the newsletter were also means through which organizations cultivated their relationship with journalists, leading to press coverage. Respondent 2 (Trans-National Institute) explained:

If we have a press event . . I I would probably just use email and our website, not necessarily Twitter. Twitter is more for us that when we have a press event happening or a public event that is also of interest to policy-makers, we would be tweeting from that event.

Bigger organizations, with a dedicated press officer, also organized press events, performed fact-checking, or provided background research for journalists. Respondent 1 (Meer Democratie) explained: "We have quite good contacts in politics, we are interviewed quite a lot in the media-and that's how you do it." For Ons Geld Stichting, the big break in enrolling stakeholder support had come from the unexpected coverage of their cause by one of the most popular Dutch TV talk shows: "The next day I was launched into this stream of happenings. ... It was so revolutionary, that this would stat the movement, because for the first time ... this topic was talked about in a way that was entertaining and that really reached the big masses" (Respondent 4, Ons Geld Stichting). 


\section{Delia Dumitrica}

\section{Using Advertising}

Finally, the complementarity of the different communication channels used by NGOs was also evidenced in organization's reliance on advertising. This reliance is quite easy to miss by looking solely at an NGO's online presence. The interviews revealed that several organizations used targeted advertising on Facebook or Instagram, but also purchased advertising space in Dutch newspapers. This advertising was not, however, aimed primarily at fundraising, but rather at amplifying particular campaigns and mobilizing publics to participate (even though fundraising might have been one element of such campaigns).

Stichting Vluegeling, for example, ran a controversial ad in a local free newspaper. The ad turned an anti-immigration message on its head, directing audiences to a dedicated website presenting a petition in support of refugee aid. Respondent 10 remember that "it created a lot of talk, and that was our goal." Other organizations were experimenting with Facebook targeted ads, either to elicit a particular response from supporters or to recruit new ones. Although in general Facebook ads were less expensive than newspaper ads, they also came with their own problems:

It costs a lot of money. ... Six years ago, people looked at social media like "oh, you can have communication for free with lots of people." But that's simply not true. It does cost.... [I]n the end we are paying with our privacy.

(Respondent 8, COC)

\section{Different Channels, Different Communication Goals}

The adoption of new social media functionalities such as Facebook ads was strategically approached with an eye to how such channels could help the organization's mission and goals. The Dutch social change NGOs in this study often talked about how different channels addressed different communicational needs, thus targeting different stakeholders. For example, everyone saw websites as a point of entry into the organization for any interested stakeholder, as well as a repository of information:

For most people who have not heard of our organization, if they search on the web, this will be the first port of call.... The website provides a first glimpse into who we are and what we stand for, what we try to reach.

(Respondent 2, Trans-National Institute)

The website was the place where the organization made issue-specific opinion pieces, commentary, or background research available, subsequently sharing this content via social media. 
Somewhat surprisingly, given the recurrent framing of social media as "participatory media" (Ciszek, 2013), websites were seen by several respondents in our sample as having an active, mobilizing role, particularly in its relationship to the newsletter (by providing people with an option to register for it). In line with Seo and Vu's (2020) findings in the context of transnational organizations, Dutch NGOs in this sample saw their websites as the most important form of reaching out to stakeholders and enrolling their support.

Different social media platforms were also ascribed different roles in relation to the organization's mission and programs. Echoing Lovejoy and Saxton's (2012) proposal that "dialogue is simply one essential piece of the communication puzzle, and that information may always be the 'base' form of communication" (p. 349), the NGOs in this sample regarded these communication channels as multipurpose. Information provision was seen as the means of establishing a common ground with publics, a common ground upon which the organization could subsequently build stronger social ties with their stakeholders. Respondent 4 (Ons Geld Stichting) explained that the website's informative role was the first step to mobilization: "[T]he idea is that through knowledge, people become a catalyst for action . . not only in the sense of going on to the streets ... but also to change the way we think." By contrast, social media channels like Facebook were used to engage the wider community and to offer them a platform for discussion.

\section{Staying on Top of Fashions and Trends}

The interviews further complexified the results of the content analysis of online communication by revealing the tension between organizations' desire to stay relevant by incorporating the newest communication channel of the day and their available resources for communication. Respondent 8 (COC Nederland) recounted the organization's experiment with Facebook ads:

It is necessary to ... present yourself on all those different social media channels, because otherwise you ... aren't visible enough.

The ten NGOs in the sample were aware of and tried to respond to trends and fashions in the use of communication channels in the Netherlands and abroad (Sheombar et al., 2015). Ideas such as "if you do not have a website, you do not exist," "journalists and politicians are the key audience of Twitter," "Facebook is for the general public," "Instagram use is going up," "youth prefer Instagram," or "Snapchat and WhatsApp are growing fast" were frequently brought up in the interviews.

Social media adoption by NGOs is shaped by organizational features (e.g., strategies, governance, leadership, capacity, and resources) along with external resource environments (Nah \& Saxton, 2013; Seo \& Vu, 2020). The explanations offered by the Dutch NGOs in this study confirmed the importance of the external resource environment, speaking to perceived 
pressures to go where the different publics (e.g., beneficiaries, journalists, politicians, etc.) are in order to remain relevant within the broader communication ecosystem.

\section{Addressing Multiple Publics: The Use of Campaigns}

Where the two-way communication paradigm in the public relations literature often assesses NGOs' social media adoption against their ability to engage in a dialogue with their publics, it was precisely this dialogical dimension that post most problems for the Dutch NGOs in this study. While respondents were familiar with the wider discourses about the participatory nature of social media, their practical experience had taught them restraint (see also Kenix, 2008; Obar, 2014). The potential was there, but mobilizing people for action or even getting new supporters was often difficult and required more than reliance on social media channels. For instance, face-toface events or the amplifying role of mass media often seemed more effective at bringing in more support from the wider audience.

Furthermore, organizations were aware of the multiple stakeholders they were addressing via social media platforms, and as such were developing strategies for navigating multiple audiences (Marwick \& boyd, 2010). One such notable strategy brought forth by the interviews was the development of a program- or campaign-specific online presence. The limited content analysis performed here could not capture the emergence of affiliated websites or social media accounts. Bigger organizations seemed to be more involved in running different campaigns, often running in parallel, as well as programs targeting different stakeholders. Respondent 8 (COC Nederland) spoke of how the different campaigns put forth by the organization were often treated as "brands" getting their distinct online presence. Respondent 6 (Milieudefensie) elaborated the communication strategy for each of the four projects the organization was running at the time of the interview. One, for example, included a petition, a dedicated newsletter, and a Facebook page-all where distinct from the organization's own communication strategy. Thus, although an organization might not be dialogic in one website or social media account, they could opt for this strategy as a component of a specific campaign or program.

This mix of communication channels was, thus, constantly changing in relation to current affairs, but also to the NGO's specific agenda. Respondent 10 (Stichting Vluegeling) explained that their organization was always revising its communication strategy, looking into how new communication channels can support its mission, strategy, and goals.

\section{Conclusion}

This chapter highlights the importance of studying social media use within the context of NGOs' communication ecosystems. Empirically, 
the chapter took an exploratory approach to mapping how Dutch social change NGOs integrate social media in their communication practices. Theoretically, the chapter juxtaposed a multi-sited, ecosystem lens to the prevailing PR paradigm examining the dialogical use of one or two social media channels. The findings of ten in-depth interviews with communication officers or advisors were compared with those of a content analysis of the organizations' online presence in order to understand what can be learned about NGOs' social media use with each method. The comparison brought forth a more nuanced picture of social media adoption as strategically inserted within the organization's wider communication ecosystem. While being present on Facebook or Twitter was certainly important for the organizations in the sample, such channels were only a component of their online communication visible by means of a content analysis. In fact, organizations seamlessly blended online and offline communication, recognizing the importance of seemingly outdated techniques such as calling supporters on the phone, spreading leaflets, or sending e-newsletters.

The communication ecosystem approach was also useful in drawing attention to the fluidity of organizations' communication mix. The organizations in this sample were monitoring the larger communicative practices of the general public and experimenting with the newest popular platform in order to remain relevant. Of relevance here was the practice of developing campaign-specific brands with their dedicated online channels. These could be easily missed by focusing solely on an NGO's official Facebook or Twitter account.

Not all experiments with campaign brands or social media adoption were successful. The interviews were able to add richness to the content analysis of an organization's online presence by bringing forth the importance of existing capitals-social, financial, symbolic-in an NGO's willingness and capability to experiment with new communication channels and genres. Furthermore, the interviews revealed how external factors such as current affairs or partnerships and collaborations with other civil society actors were also shaping NGOs' communication strategies. Yet, even for NGOs with dedicated communication teams, the investment required to include additional social media channels in the communication mix stretched the organization's human and financial resources.

The ecosystem approach illustrated here also brought forth the ongoing centrality of mass media and of face-to-face communication with decisionmaking elites. In interviews, NGO representatives brought up the role of mass media coverage or advertising in the successful mobilization of their stakeholders. This appears consistent with the larger communication ecosystem in the Netherlands, where mass media remain important to citizens' information and socialization practices. Social media use does not take place in a vacuum. It develops within and remains tributary to the organization's communication ecosystem. This suggests that the integration of new 
communication channels remains fluid, changing with needs and resources, but also with the life cycle of a program or campaign. Capturing this fluidity in a way that pays heed to the contextual factors shaping it requires a multisited and nuanced approach in the study of social change NGOs' strategic communication.

\section{References}

Adjei, D. K. A., Annor-Frempong, F., \& Bosompem, M. (2016). Use of social networking websites among NGOs in the Greater Accra Region of Ghana. Public Relations Review, 42(5), 920-928.

Auger, G. A. (2013). Fostering democracy through social media: Evaluating diametrically opposed nonprofit advocacy organizations' use of Facebook, Twitter, and YouTube. Public Relations Review, 39, 369-376.

Bastos, M. T., Mercea, D., \& Charpentier, A. (2015). Tents, tweets, and events: The interplay between ongoing protests and social media. Journal of Communication, 65(2), 320-350.

Bekkers, V., Beunders, H., Edwards, A., \& Moody, R. (2011). New media, micromobilization, and political agenda setting: Crossover effects in political mobilization and media usage. The Information Society, 27(4), 209-219.

Bekkers, R. H. F. P., Schuyt, T. N. M., \& Gouwenberg, B. M. (2015). Giving in the Netherlands: Donations, bequests, sponsoring and volunteering. Amsterdam: Reed Business.

Bortree, D.S., \& Seltzer, T. (2009). Dialogic strategies and outcomes: An analysis of environmental advocacy groups' Facebook profiles. Public Relations Review, 35(3), 317-319.

Brandsen, T., \& Pape, U. (2015). The Netherlands: The paradox of governmentnonprofit partnerships. Voluntas, 26, 2267-2282.

Burger, A., \& Dekker, P. (2001). The nonprofit sector in the Netherlands. Working document 70. Sociaal en Cultureel Planbureau, Den Haag. Retrieved December 27, 2019, from https://www.scp.nl/english/Publications/Publications_by_year/ Publications_2001/The_nonprofit_sector_in_the_Netherlands

Burger, A., Dekker, P., Toepler, S., Anheier, H. K., \& Salamon, L.M. (1999). Chapter 7: Netherlands. In L. M. Salamon, H. K. Anheier, R. List, S. Toepler, S. W. Sokolowski, \& Associates (Eds.), Global civil society: Dimensions of the nonprofit sector (pp. 145-162). Baltimore, MD: The Johns Hopkins Center for Civil Society Studies.

Burger, A., \& Veldheer, V. (2001). The growth of the nonprofit sector in the Netherlands. Nonprofit and Voluntary Sector Quarterly, 30(2), 221-246.

Campbell, D., \& Lambright, K. (2018). Nonprofit organizations' use of the internet and social media. In A. Farazmand (Ed.), Global encyclopaedia of public administration, public policy, and governance. Cham: Springer. https://doi.org/10. 1007/978-3-319-31816-5_3302-1

Chadwick, A. (2013). The hybrid media system. Politics and power. New York: Oxford University Press.

Cho, M., Schweickart, T., \& Haase, A. (2014). Public engagement with nonprofit organizations on Facebook. Public Relations Review, 40, 565-567.

Ciszek, E. (2013). Advocacy and Amplification: Nonprofit Outreach and Empowerment Through Participatory Media. Public Relations Journal, 7(2), 187-213. 
Dumitrica, D., \& Achterberg, E. (2017). Digital activism and the civic subject position: A study of the Ons Geld (Our Money) citizen initiative in the Netherlands. In P. Parychek \& N. Edelmann (Eds.), Proceedings of the 7 th International Conference for E-Democracy and Open Government CeDEM17 (pp. 229-242). Washington: Los Alamitos.

Edwards, H.R., \& Hoefer, R. (2010). Are social work advocacy groups using web 2.0 effectively? Journal of Policy Practice, 9(3-4), 220-239.

Encyclopædia Britannica (2019). Ecosystem. Published February 13, 2019. Retrieved July 24, 2019, from https:/www.britannica.com/science/ecosystem

Gemeente Den Haag (2013). Guide to International Organisations in The Hague. The Hague.

Greenberg, J., \& MacAulay, M. (2009). NPO 2.0? Exploring the web presence of environmental nonprofit organizations in Canada. Global Media Journal-Canadian Edition, 2(1), 63-88.

Guo, C., \& Saxton, G. D. (2018). Speaking and Being Heard: How Nonprofit Advocacy Organizations Gain Attention on Social Media. Nonprofit and Voluntary Sector Quarterly, 47(1), 5-26.

Guidry, J. P. D., Jin, Y., Orr, C. A., Messnera, M., \& Meganck, S. (2017). Ebola on Instagram and Twitter: How health organizations address the health crisis in their social media engagement. Public Relations Review, 43, 477-486.

Harrison, V.S., Xiao, A., Ott, H. K., \& Bortree, D. (2017). Calling all volunteers: The role of stewardship and involvement in volunteer-organization relationships. Public Relations Review, 43(4), 872-881.

Inauen, S., \& Schoeneborn, D. (2014). Twitter and its Usage for Dialogic Stakeholder Communication by MNCs and NGOs. In R. Tench, W. Sun, \& B. Jones (Eds.), Communicating Corporate Social Responsibility: Perspectives and Practice (pp. 283-310). Bingley: Emerald Group Publishing.

Janssen Danyi, C., \& Chaudhri, V. (2018). Strategic social media management for NGOs. In J. Servaes (Ed.), Handbook of Communication for Development and SocialChange.Singapore:Springer.https://doi.org/10.1007/978-981-10-7035-8_72-1

Kenix, L. J. (2008). Nonprofit organisations. Perceptions and uses of the Internet. Television and New Media, 9(5), 407-428.

Kim, D., Chun, H., Kwak, Y., \& Nam, Y. (2014). The employment of dialogic principles in website, Facebook, and Twitter platforms of environmental nonprofit organizations. Social Science Computer Review, 32(5), 590-605.

Koch, D. J., \& Loman, B. (2009). Geographical choices of Dutch NGOs: Orthodoxies and realities. In P. Hoebink (Ed.), The Netherlands yearbook on international cooperation 2008 (pp. 51-82). Assen: Van Gorcum.

Lovejoy, K., \& Saxton, G. D. (2012). Information, community, and action: How nonprofit organizations use social media. Journal of Computer-Mediated Communication, 17, 337-353.

Lovejoy, K., Waters, R. D., \& Saxton, G. (2012). Engaging stakeholders through Twitter: How nonprofit organizations are getting more out of 140 characters or less. Public Relations Review, 38, 313-318.

Macnamara, J. (2010). Public relations and the social: How practitioners are using, or abusing, social media. Asia Pacific Public Relations Journal, 11(1), 21-39.

Marwick, A., \& boyd, d. (2010). I tweet honestly, I tweet passionately: Twitter users, context collapse, and the imagined audience. New media or society, 13(1), 114-133. 
Mattoni, A. (2017). A situated understanding of digital technologies in social movements: Media ecology and media practice approaches. Social Movement Studies, 16(4), 494-505.

Mattoni, A., \& Treré, E. (2014). Media practices, mediation processes, and mediatization in the study of social movements. Communication Theory, 24(3), 252-271.

Meijer, M., de Bakker, F. G., Smit, J. H., \& Schuyt, T. (2006). Corporate giving in the Netherlands 1995-2003: Exploring the amounts involved and the motivations for donating. International Journal of Nonprofit and Voluntary Sector Marketing, 11(1), 13-28.

Morell, M. F. (2012). The Free Culture and 15M movements in Spain: Composition, social networks and synergies. Social Movement Studies, 11(3-4), 386-392.

Nah, S., \& Saxton, G. D. (2013). Modeling the adoption and use of social media by nonprofit organizations. New Media \& Society, 15(2), 294-313.

Namisango, F., \& Kang, K. (2019). Organization-public relationships on social media: The role of relationship strength, cohesion and symmetry. Computers in Human Behavior, 101, 22-29

Obar, J. A. (2014). Canadian advocacy 2.0: An analysis of social media adoption and perceived affordances by advocacy groups looking to advance activism in Canada. Canadian Journal of Communication, 39(2), 211-233.

Powers, M. (2015). Contemporary NGO-journalist relations: Reviewing and evaluating an emergent area of research. Sociology Compass, 9(6), 427-437.

Reuters Institute (2018). Media Monitor 2018. Retrieved July 24, 2019, from https://www.cvdm.nl/wp-content/uploads/2018/06/Mediamonitor-2018-ReutersInstitute-Digital-News-Report-Nederland-2018.pdf

Ricciutti, E., \& Calò, F. (2018). NGOs and governance. In A. Farazmand (Ed.), Global encyclopaedia of public administration, public policy, and governance. Cham: Springer. https://doi-org.eur.idm.oclc.org/10.1007/978-3-319-31816-5_3213-1

Saxton, G. D., \& Guo, C. (2014). Online stakeholder targeting and the acquisition of social media capital. International Journal of Nonprofit and Voluntary Sector Marketing, 19(4), 286-300

Saxton, G. D., \& Waters, R. D. (2014). What do stakeholders like on Facebook? Examining public reactions to nonprofit organizations' informational, promotional, and community building messages. Journal of Public Relations Research, 26(3), 280-299.

Schuyt, T.N.M., Gouwenberg, B.M., \& Bekkers, R.H.F.P. (2013). Giving in the Netherlands 2013: Donations, Bequests, Sponsorship and Volunteering. Amsterdam: Reed Business.

Schulpen, L. (2016). The NGO funding game. The case of the Netherlands. Nijmegen: CIDIN, Radboud University.

Seo, H., \& Vu, H. T. (2020). Transnational nonprofits' social media use: A survey of communications professionals and an analysis of organizational characteristics. Nonprofit and Voluntary Sector Quarterly, 49(4), 849-870.

Seo, H., Kim, J. Y., \& Yang, S. (2009). Global activism and new media: A study of transnational NGOs' online public relations. Public Relations Review, 35(2), 123-126.

Sheombar, A., Urquhart, C., Ndhlovu, T., \& Ravesteijn, P. (2015). Social Media in the Context of Development: A Case Study of Dutch NGOs. ECIS 2015 Completed Research Papers. Paper 167. Retrieved July 23, 2019, from http://aisel.aisnet.org/ ecis2015_cr/167 
Svensson, P.G., Mahoney, T. Q., \& Hambrick, M. E. (2015). Twitter as a communication tool for nonprofits: a study of sport-for-development organizations. Nonprofit and Voluntary Sector Quarterly, 44(6), 1086-1106.

Taylor, M., \& Kent, M. L. (2014). Dialogic engagement: Clarifying foundational concepts. Journal of Public Relations Research, 26(5), 384-398.

Treré, E. (2018). The sublime of digital activism: Hybrid media ecologies and the new grammar of protest. Journalism \& Communication Monographs, 20(2), 137-148.

Treré, E., \& Mattoni, A. (2016). Media ecologies and protest movements: Main perspectives and key lessons. Information, Communication \& Society, 19(3), 290-306.

Ugur, Z. B. (2018). Donate more, be happier! Evidence from the Netherlands. Applied Research Quality Life, 13(1), 157-177.

Verhoeven, I., \& Tonkens, E. (2013). Talking active citizenship: Framing welfare state reform in England and the Netherlands. Social Policy o Society, 12(3), 415-426.

Waters, R.D., \& Jamal, J.Y. (2011). Tweet, tweet, tweet: A content analysis of nonprofit organizations' Twitter updates. Public Relations Review, 37(3), 321-324.

Waters, R.D., Burnett, E., Lamm, A., \& Lucas, J. (2009). Engaging stakeholders through social networking: How nonprofit organizations are using Facebook. Public Relations Review, 35(2), 102-106.

Wiepking, P., \& van Leeuwen, M. H. D. (2013). Picturing Generosity: Explaining the Success of National Campaigns in the Netherlands. Nonprofit and Voluntary Sector Quarterly, 42(2), 262-284. 


\title{
$5 \quad$ Narrative Strategies for Animated Development Communication
}

\author{
Examples From BRAC in Bangladesh
}

\author{
Naima Alam
}

Bangladesh has seen a strong upward rise in their economy since their independence in 1971. Bangladesh is well known for its export of readymade garments (RMG) for common Western clothing brands such as H\&M, Zara, Calvin Klein, and Tommy Hilfiger. Along with RMG, the country also exports agricultural products and labor to developed countries such as Singapore, Malaysia, and the United Arab Emirates. In the last 50 years, the country has seen a fast economic rise based on its cheap labor force. The country's current population is 170 million people with women accounting for half of the population (IMF, 2020). In the RMG sector that contributes to $83 \%$ of the country's export earning, $80 \%$ of the labor force are women (Akhter et al., 2019). However, even though these women power the industry, they still have to deal with low wages, hazardous work environments, and unstable employment contracts (Quayyum, 2019). While women contribute significantly to the Bangladeshi economy, with some even running their own businesses, traditional cultural notions about a woman's place continue to weaken their social position.

Alongside other South Asian countries, the precarious social status of women is not a new problem in Bangladesh (Aghi \& Carnegie, 1996; McKee et al., 2004). Even before the partition of India, Pakistan, and Bangladesh, women there were facing extreme discrimination due to a strong cultural and economic preference for having sons over daughters-sons meant financial gain, while daughters meant financial burdens. Due to these and other traditional beliefs and practices, South Asian girl children in the 1970s and 1980s were faced with discrimination in terms of education, health, and financial development (McKee et al., 2004). Subsequently, the South Asian Association for Regional Cooperation termed the 1990s as the "Decade of the Girl Child" (McKee et al., 2004, p. 334). Since then, many international non-governmental organizations (hereafter NGOs) have been working relentlessly toward bringing equal opportunity and social change for the women of South Asia, including NGOs such as ActionAid, UNICEF, UN Women, to name a few. In Bangladesh, local NGOs such as the Bangladesh Women's Foundation continue to play a significant role in this social change effort.

DOI: $10.4324 / 9781003188636-7$ 
The major outreach tool that has been employed to change the viewpoint of the Bangladeshi population on gender equity is electronic media. In the 1990s, this was done through broadcasting entertainment education (E-E) animated cartoons such as UNICEF's Meena, depicting strong girls and women on the state-owned national television channel BTV (Aghi \& Carnegie, 1996). In rural Bangladesh, NGOs set up mobile makeshift theaters to play E-E videos for the public. As a response to the "Decade of the Girl Child," UNICEF developed an E-E animated cartoon series with a female protagonist called "Meena," which first aired on BTV in 1993. Since the early 2000s, Bangladesh's information and entertainment has moved to mobile and online telecommunications - $54 \%$ of the population uses mobile phones and 58.4\% has Internet access, also in rural areas (Islam, 2020). Due to Meena's long-lasting success, the Bangladeshi government continues to coproduce short animated videos with NGOs for television and social media. Today, the Meena Communication Initiative (MCI) generates analogue and digital gender equality communication materials (Chatterjee et al., 2020).

NGOs use animated videos in their campaigns. In particular, explainer videos (hereafter, simply called explainers) have been gaining popularity. Explainers are a short one- to three-minute animated videos that explain a topic using graphic visuals and voice-over narration to present simple key facts and figures (Ivanova, 2017; Krämer \& Böhrs, 2017). Explainers were first seen in 2008 on YouTube, providing explanations for technology use, including Twitter and Dropbox (Ivanova, 2017). In Bangladesh, NGOs partner with communication agencies and animators to create a hybrid narrative strategy that combines common explainer strategies for efficient information dissemination and E-E strategies for emotional engagement to create short videos for local audiences (Chesterton, 2004).

In this chapter, I will demonstrate this hybrid narrative strategy adopted by one such NGO in Bangladesh, the Building Resources Across Communities (BRAC). BRAC is currently the world's largest NGO (McCarthy, 2018), reaching 110 million people living in poverty, and employing over 110,000 development professionals (Stiching BRAC International, 2019). The two animated videos under analysis pertain to BRAC's social development projects around gender equality, including domestic violence and maternal health. Upon a brief introduction of BRAC and their role in the development sector of Bangladesh, this chapter proceeds with an overview of explainer animation and E-E strategies to analyze BRAC's hybrid narrative strategy. Finally, I offer lessons learned from BRAC and provide suggestions to NGO practitioners on using explainers to communicate social issues.

\section{A Brief Introduction to BRAC}

BRAC was initially established in 1972 to provide relief and rehabilitation to refugees of the Bangladesh liberation war. On its official website, 


\section{Naima Alam}

BRAC articulates its vision to free the world from "all forms of exploitation and discrimination where everyone has the opportunity to realise their potential" (BRAC a). Through their various projects, BRAC's mission is to "empower people and communities in situations of poverty, illiteracy, disease and social injustice" (BRAC a). Through each intervention campaign, the NGO attempts to "achieve large scale, positive changes through economic and social programs that enable women and men to realize their potential" (BRAC a). BRAC defines four main implementation areas: (1) social development; (2) social enterprise; (3) investment; and (4) university. Most of these projects have a specific focus for their key service population: developing skills and improving the lives of women.

Previous studies on BRAC have focused on the impacts of their community outreach programs in areas such as poverty alleviation, reproductive education, health care services, and education, to name a few. Ahmed (2008) observed that the financial burden of health care let poor households in Bangladesh to delay medical care, which is why BRAC's community workers, the Shasthya Sebika, who give out information about nutrition and sanitation have become of utmost importance. Indeed, BRAC's campaigns reach their target populations well. Raza et al. (2012) have observed that governmental poverty reduction programs often fail to include the poorest communities, whereas BRAC's microcredit-based interventions have yielded high impact on issues like food security. Chowdhury and Bhuiya (2004) echo this observation and found that BRAC's family initiatives increased survival rate and the acceptance of family planning techniques better than government campaigns. On a cultural level, Nath (2002) argues that BRAC's literacy initiatives among disadvantaged populations also prepare them for further education through formal schooling. Along the same lines, Rashid (2000) found that BRAC'S Adolescent Reproductive Health Education program has helped break the silence and stigma in families and thus positively impacted intergenerational communication about family planning. These are just a few areas in which BRAC has made a large impact in Bangladesh.

Since 2002, BRAC has also been internationalizing its operations-the NGO has expanded to ten countries in Asia and Africa and established the Dutch subsidiary "Stitching BRAC International.” In 2020, for the fifth consecutive year, BRAC was ranked number 1 NGO out of the world's top 500 NGOs, by NGO Advisor, an independent Geneva-based media organization (NGO Advisor, 2021; The Daily Star, 2020). Furthermore, BRACs available infrastructure and large workforce makes the NGO an ideal implementation partner for other international NGOs and donor organizations working in Bangladesh. This is why, when Bangladesh was introduced to its first ever animated E-E tool by UNICEF, BRAC became the ideal partner for the project's sustainability plan.

As part of UNICEF's long-term vision for sustainability through local organizations, MCI was moved to BRAC (Chesterton, 2004). Since early 1997, BRAC started screening Meena cartoons through their Rural Credit 
Program outlets and have also included Meena comics in the curriculum of their 32,000 community-based primary schools (McKee et al., 2004). In 2015, BRAC started a YouTube channel ("BRAC World") to offer animated content, including animated explainers. Explainers have seen increasing use in NGO communication practices, as they convey key information quickly and clearly. This is particularly advantageous for social change campaigns.

\section{Explainers for Social Change Campaigns: Features and Strategies}

The digital revolution and the transformation of communication technology has led to an increase in social networking possibilities and has contributed to the high usage of social media applications like Facebook, YouTube, Twitter, and the like. As a result, NGOs have also started to incorporate these tools into their (online) communication strategies. Social media are employed to raise funds, inform about the core mission, educate about services and campaigns, and also engage key publics and stakeholders. The potential of social media communication for developing an organizational identity has sparked the interest of NGOs in recent years (Waters \& Jones, 2011). As a public relations channel, social media can become "central to the dissemination of core values and building of support" (Auger, 2013, p. 370). Especially the production of videos has proven to be an effective and powerful tool. As Waters and Jones (2011) explain, "while pictures help reinforce the words and content of identity-oriented messages ... the creation of organization videos may be the most powerful method of creating a strong mental impression of the organization in the public's mind" (p. 249). Explainer videos, as well as other types such as $360^{\circ}$ videos, behindthe-scenes stories, or the live streaming of events, have demonstrated to be a productive way to connect and strengthen their relationship with external stakeholders (García-Orosa \& Pérez-Seijo, 2020). Embedding these videos into social media channels offers NGOs a way to transform their one-way communication and make conversations interactive. Most NGOs are primarily using YouTube as their communicative platform to increase their organization's visibility and encourage engagement with the public (Waters \& Jones, 2011).

Social media uses in Bangladesh have been increasing rapidly. In May 2020, Bangladesh had 96 million Facebook users, which allows NGOs to distribute their social communication to almost $60 \%$ of the population (Internet World Stats, 2020). Explainers developed by NGOs are often played on local cable channels in advertisement slots and then shared on the NGO's Facebook and YouTube channels. Whether created for YouTube, Facebook, television, or an organization's website, explainers share certain characteristics, including length (Krämer \& Böhrs, 2017). Brevity affects viewer engagement and retention, allowing explainers to compete with entertaining materials. A 2016 analysis of viewer engagement of 1.3 billion plays on 546,710 videos shows that the maximum length that can maintain 


\section{Naima Alam}

audience attention for the full video is two minutes (Fishman, 2016) -if the explainer is an announcement (e.g., project or service promotion), then 30 seconds is the best length (French, 2017); if the explainer is trying to explain a concept and/or providing instructions, then two minutes ensure clear message delivery (French, 2017). Explainers have received attention in academic and non-academic literature, including outlets such as practitioner blogs, marketing reports, NGO training reports, or animator websites. Drawing on this diverse information pool, this chapter employs a framework to analyze the content of explainer animations that also pays attention to the key messages and audiovisual elements.

\section{Analysis Framework}

This analysis framework suggests looking at explainers in terms of three main components: auditory elements, visual design, and narrative strategy. First, auditory elements include voice-over and background music. Simultaneous voice-over explanation with a conversational tone and simple language has been found to produce the most effective learning (Mayer \& Moreno, 2002; Kilroy, 2018). With respect to background music, practitioners recommend its use to set the tone (Kachan, 2020), while researchers argue that it may result in cognitive overload (Mayer \& Moreno, 2002). Second, visual design includes the background, static images, and animated graphics. Visuals can be literal (e.g., an animated heart that pumps blood) or metaphoric (e.g., a web to portray digital connectivity). Visualizations span from hand-drawn illustrations and digital graphics to photos and short video clips. Here, animation techniques include stop-motion, whiteboard animation, typography, motion graphics, and 3D animation (Ivanova, 2017). Third, the narrative strategy determines how the story will be told. It ensures that the narration focuses on the main message, while the storytelling remains engaging (Krämer \& Böhrs, 2017). It weaves together facts and figures with entertaining story elements, such as relatable characters. A focus on relevant information and message clarity ensures audience comprehension (Verstiuk, 2020). For explainers aimed at behavior change, the probability of effective persuasion lies in the clarity of the main message and its systematic integration into the entire narrative (Slater \& Rouner, 2002).

The main idea for the average explainer is to take a problem-solution approach (Kilroy, 2018). Table 5.1 provides an overview of three common narrative strategies suggested by global practitioners: "Meet Bob," "Announcement," and "Process Overview." "Meet Bob" is the most common narrative strategy used in explainers (Oentoro, 2018). The narrator introduces the audience to a fictional character and tells the audience about the character's problem. Then, the narrator offers a solution followed by an explanation of the process to achieve this solution. The audience sees positive results in the character's life and is encouraged to change their own actions. The "Announcement" is most commonly used for public service 
Table 5.1 Common narrative strategies for explainer animations (Kilroy, 2018; Oentoro, 2018; Verstiuk, 2020)

\begin{tabular}{llll}
\hline Narrative & Meet Bob & Announcement & Process Overview \\
\cline { 2 - 4 } Strategies & Meet Character $>$ Prob- & Short Introduction $>$ & Introduction $>$ \\
& lem $>$ Solution $>$ Process $>$ & Main Message $>$ & Steps \\
& Results $>$ Call-to-Action & Details $>$ Call-to-Action & \\
\hline
\end{tabular}

announcement videos (Verstiuk, 2020). These explainers focus on the main message, providing more detailed information and ending with a call-toaction. And the "Process Overview" narrative strategy offers a breakdown of steps and is commonly used for instructional videos (Kilroy, 2018).

In BRAC's communication practices, the NGO most commonly relies on explainers that follow the "Meet Bob" narrative strategy. For longer public service announcements, BRAC often combines the "Announcement" and "Process Overview" strategy. In their animated content, BRAC tailors their explainers to the communication needs of its organization, taking into consideration cultural taste and the campaign's key message. An important aspect is BRAC's history with MCI, which focuses on women's health and rights in South Asia through relatable characters and localized stories. The Meena animations are part of the entertainment-education (E-E) strategy in BRAC's advocacy communication (McKee, 2004).

E-E is a communication strategy aimed at supplementing campaigns that drive social change (Singhal \& Rogers, 2004). E-E includes embedding educational content into entertainment formats with the objective to influence behavior or change social mindset. Ultimately, E-E fosters social mobilization to influence public perceptions and drive more equitable policy dialogues (Singhal \& Rogers, 2004). In order to achieve this goal, E-E recommends the use of customizing visuals, audio elements, and narratives to locally established archetypes in order to connect to them on an emotional level. The following passage introduces some common archetypes previously used by NGOs to create women's rights awareness in Bangladesh and rest of South Asia.

\section{Popular Archetypes in Bangladeshi NGO Animations}

The "use of story-telling to influence behaviour is at least as old as Aesop and is deeply ingrained in Western as well as non-Western cultures" (Slater, 2002, p. 158). The Jungian archetypical characters (Jung, 1970) all display universal patterns and highlight certain characteristics and exist in folklores, mythologies, and legends. These archetypes are familiar characters in relatable situations, the most common of which is the "hero" who has to overcome barriers to reach his final goal. The first time Bangladeshi audiences experienced these archetypes in a Bangla-speaking animation was through 
UNICEF's 13 episodes of the 13-minute animated series called "Meena" in the 1990s. The animated series created awareness of women's health and legal rights related issues using relatable archetypical characters based on stories from local audiences. The series included the "the innocent child" and the "wise old woman," which were favored in many fairy tales from Bangladesh and the neighboring countries.

Not only are these archetypes present in Bangladeshi stories, but they are also present in daily narratives. Even today, women in Bangladesh are expected to embody this idea of innocence and purity throughout their life. There is a strong aversion toward women having too much knowledge. Women are often discouraged to pursue higher education as it would make them too independent and unsuitable for marriage. In Bangladeshi culture, the innocent, childlike bride is romanticized as she is easier to control. It is believed that if a woman is too strong or independent, then it will lead to her forgetting cultural boundaries and disrespecting her family. The animated series Meena tackles this issue in two ways. First, the character Meena herself respects and obeys her elders. So even when they share their misconceptions such as "girls should not go to school" in the first episode "Meena: Count Your Chickens" (UNICEF Bangladesh), she accepts their opinion. Later she finds a way of showing them the benefits of school education, which convinces them to send her to school without feeling that their cultural values are disrupted. Second, the schoolteacher and the village health worker are respectable characters to whom Meena and her family go for advice. These women embody the archetypical trope of the "wise woman," who appears at the right time to provide valuable information. At one point, they also introduced a female bank manager to show that women and men are both equally equipped to handle the family's finances.

Although only the perspective of the audiences from Bangladesh are presented here, MCI was developed to be distributed throughout South Asia. The archetypes and social situations portrayed in the stories reflect gender inequality issues faced in India, Pakistan, and Nepal as well (Aghi \& Carnegie, 1996). The representation incorporates localized audio and visual elements from each country involved in the project (Aghi \& Carnegie, 1996). For the audio, the language spoken is a local colloquial dialect suggested by practitioners from individual countries. The success of the series has led the episodes to be currently dubbed in 30 more languages, including Arabic, Burmese, Chinese, and French (Kenyon, 2001). The visual elements depict a generic South Asian village with farmlands, waterbodies, and houses that can be found in these countries (Alam, 2021). BRAC has adapted some of these rural visuals and archetypes into their animations in order to reach similar emotional relatability with their audience.

\section{Two Explainer Animations From BRAC}

The following two videos have been chosen from BRAC's YouTube channel as both of them use two versions of the "wise woman" archetype in their 
visual and narrative strategies. Despite many NGO and government campaigns for women's rights, domestic violence is a pervasive issue in Bangladesh. These acts of violence can include "beatings and other physical attacks, verbal and emotional abuse, and economic control," and marital rape (Human Rights Watch, 2020, para. 2). Although divorce is legally permitted, many women do not know about the law and are also afraid of social stigma. The first video "Rabeya's right to a happy life, free of abuse" tackles the topic of domestic abuse and women's legal rights to stand up against it (BRAC, 2017). This video is one out of a series of four animated videos produced to create awareness on the services provided by BRAC's Human Rights and Legal Aids Services Centre (BRAC HRLS).

The second video “গর্ভবতী ও নতুন মায়েরা থাকুক নিরাপদ" (“Keep pregnant and new mothers safe") provides information on prenatal and maternal health care during the COVID-19 pandemic (BRAC, 2020). This video was created to address pregnancy-related safety precautions and nutritional information that young women would usually receive from their gynecologist when expecting their first baby. However, during the first wave of the COVID-19 pandemic, many people, including expecting mother, were avoiding going to hospitals for checkups, in the fear of catching or bringing home the deadly disease. Therefore, this video was used to distribute this information to BRAC's audience members. Some of the problems addressed in this video are specific to household tasks usually undertaken by women living in rural or semiurban Bangladesh. For example, homemakers are often expected to do a lot of heavy lifting and other manual labor such as fetching water, handwashing laundry, or moving large cooking pots in the kitchen even during their early stages of pregnancy. This explainer is part of BRAC's social development initiative focusing on health and nutrition. Both videos are 2 minute 26 seconds long. The following analysis uses the three components of explainer in this sequence: narrative strategy, auditory elements, and visual design.

\section{Analysis of BRAC Animations}

"Rabeya's right to a happy life, free of abuse" is an explanatory video. Here the main message of the first video is to create awareness about the forms of domestic violence and the availability of legal help against such violence from BRAC HRLS. As the video covers a taboo and private topic such as violence in the home, it has to build context and make itself relatable to the audience within the first 30 seconds so that they do not scroll away. Using a common Bengali name and a scenario of an interaction between husband and wife can achieve this goal easily and efficiently. This is why the narrative strategy utilized for this video is "Meet Bob" (Meet Bob > Problem > Solution $>$ Process $>$ Results $>$ Call-to-action), with "Rabeya" as the lead character. Here, instead of the usual narrator introducing the character, Rabeya's husband, the farmer, calls out her name, demanding she bring him water. His mother brings him water and encourages his anger at his wife's absence 
(Figure 5.1.1), setting the stage for the problem, domestic abuse. Adding the mother-in-law character helps to quickly escalate the situation and allows the video to show the problem within the 60-second mark. In Figure 5.1.2, the wife arrives with fresh rice grains and says in a teasing manner, "What will you eat if I do not prepare the rice?" This kind of teasing dialogue from Rabeya is a common speech style of women in Bangladesh coming from their tongue-in-cheek kind of humor and will have been heard or used by the audience in real-life scenarios. This makes her an easily relatable character. However, due to his bad mood, her attempt at humor makes her husband feel insulted and intensifies his rage. This is then clearly depicted in Figure 5.1.3, where he is about to hit her at 37 seconds. To keep the video acceptable for viewers of all age groups, the abuse itself is not shown. Next, the solution is shown in Figure 5.1.4, where Rabeya is seen washing dishes by the pond and is approached by BRAC's legal aid. The legal aid introduces Rabeya to the process of solving her problem, explaining her rights to take legal action against her husband and in-laws (Figure 5.1.4). She describes the different forms of abuse and the availability of legal actions such as divorce. However, due to the short length of the video, the entire process of divorce or making legal charges is not explained here. As the aim of the video is to bring the audience to BRAC HRLS, the legal aid simply ends with her call-to-action, "To find out more about these issues come to the legal education class, provided by BRAC's Human Rights and Legal Aid Services Centre (HRLS)." The final results of learning the process are represented by
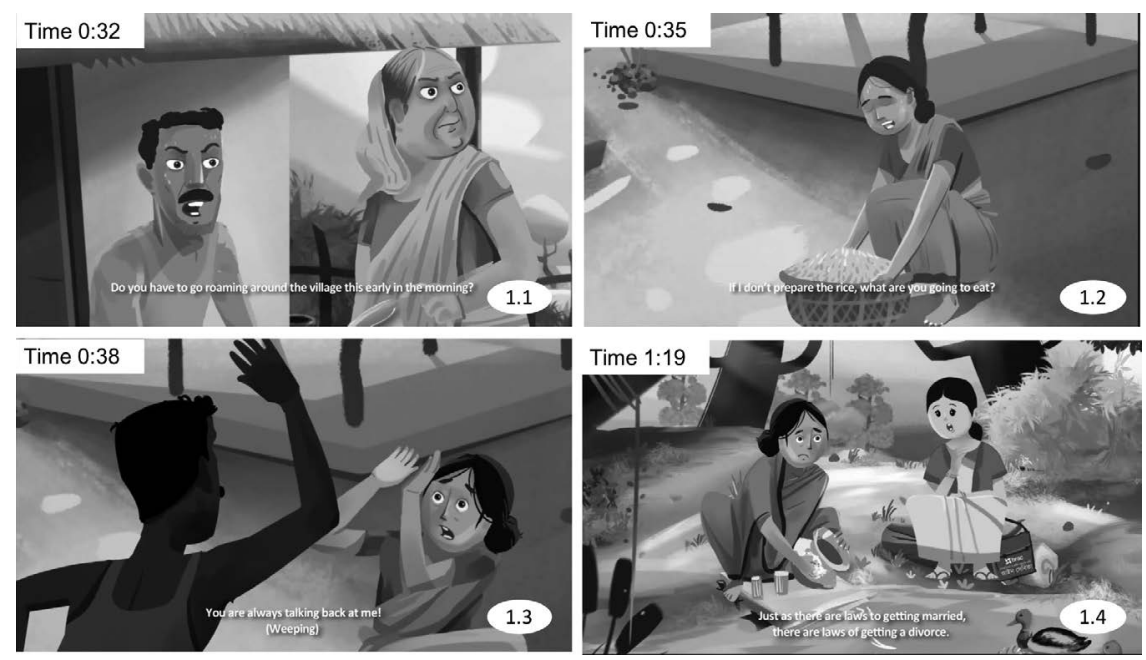

Figure 5.1 Collage of images of four scenes from "Rabeya's right to a happy life, free of abuse" (BRAC, 2017).

Note: The top left corner of each image shows the time stamp and the bottom right corner is the number used to refer to the image. 

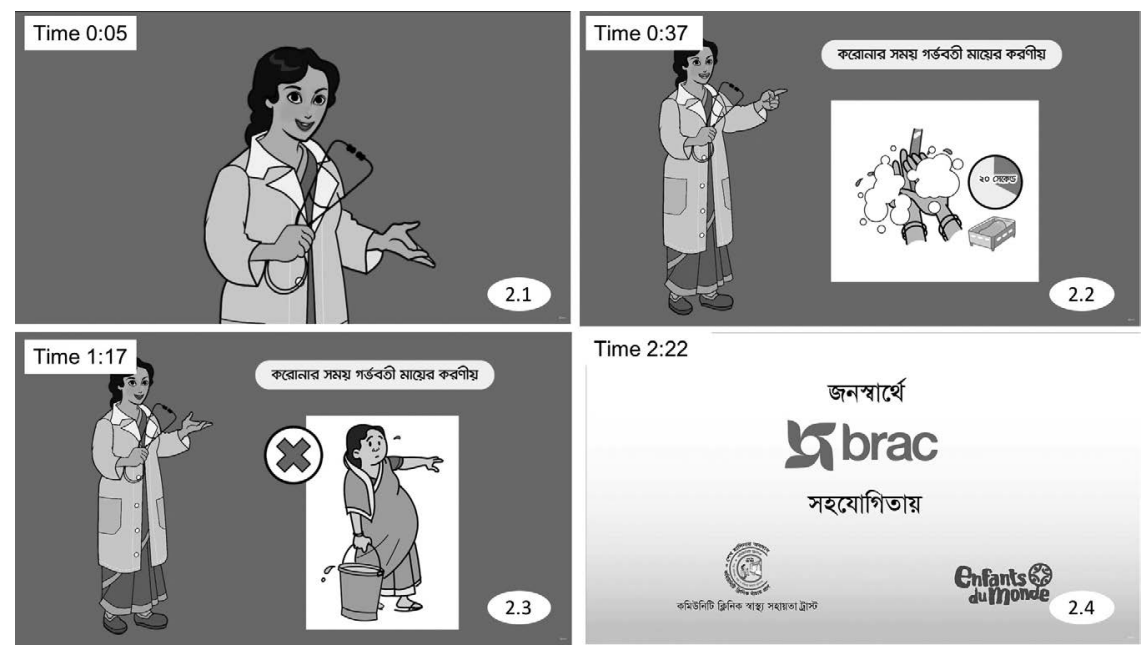

Time 2:22

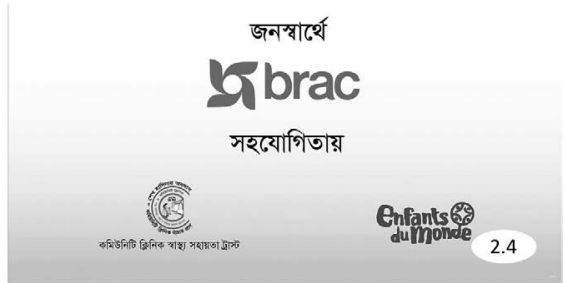

Figure 5.2 Collage of images of four scenes from “গর্ভবতী ও নতুন মায়েরা থাকুক নিরাপদ" (BRAC, 2020).

Note: The top left corner of each image shows the time stamp and the bottom right corner is the number used to refer to the image.

Rabeya's relief at the end of the video where she says, "This gives me courage. I will definitely come and attend the class." BRAC's legal aid arrives right when Rabeya is feeling scared and vulnerable and gives Rabeya exactly the information she needs, similar to the health worker in Meena, the archetypical wise woman.

The auditory elements of the video play a significant part in splitting up the narrative segments of the video for the Bangladeshi audience into two distinct sections: emotional and informational. The emotional section of the story of Rabeya's abuse has melancholic Bengali string instruments as background music. This kind of musical score is typically used in Bengali dramas portraying village life and in MCI. The informational section starting at 1 minute 16 seconds has no music so that the information can be heard clearly. Moreover, the video uses a dialogue-based delivery instead of voice-over narration.

When it comes to the visual design, the first thing one notices are the very Bengali-looking characters wearing Bengali attire. Rabeya and her motherin-law are both wearing faded single pleat saris, which is a simple way of wrapping the sari without extra pleats in the middle. Usually, women will dress like this when doing housework or manual labor. Rabeya's husband is wearing a faded tank-top (Figures 5.1.1 and 5.1.3) and shorted lungi (wrap around skirt worn by Southeast Asian males) that cannot be seen in the images. The legal aid is dressed in a clean bright green sari (three straight 
lines show the pleats on her sari) and she carries a bag to signify her status as an educated woman. Her bag clearly states "BRAC legal aid" in Bangla script to show who she is. She also wears a coat on top of her sari, which is highly uncommon. Women only wear coats on top of their saris when they are doctors or lawyers. The color of the jacket is bright magenta, close to the color of BRAC's logo. The background in Figure 5.1.1 shows their straw-roofed house, and Figure 5.1.4 shows a village setting with mud roads and trees. Creating this kind of scenery as an environment diverges from the typical explainer visuals, which are usually more simplistic. However, this converges with the Meena's visual style. Rabeya fulfills the archetype of the weak and innocent. When the legal aid explains domestic violence and abuse to her, she says, "I never knew this was an offence." Even after being beaten, her fear is of being divorced by the husband and, thus, losing her home. She is also seen squatting in almost the whole video, setting her at a visually lower position than everyone else.

As a whole, the narrative strategy, auditory elements, and visual design work together to create a complete and relatable story for the audience. The narrative strategy "Meet Bob" allows the organization to tell an interesting and informative story in a short time. The village themed visual format lets the rural audience know at first glimpse whether the video is relatable to their own life situations. The combination of the narrative strategy with a dialogue-based auditory delivery and the visual elements allows the audience members to understand the context of the video and get drawn into the character's story in a very short time. Furthermore, they learn the legal solutions against domestic violence and the process of getting aid from BRAC HRLS, while being entertained by watching an animated drama about somebody else's life. This way, they do not have to feel ashamed or shy about wanting to learn more about the topic.

The second video "গর্ভবতী ও নতুন মার্যেরা থাকুক নিরাপদ" ( “Keep pregnant and new mothers safe") (BRAC, 2020) is an instructional explainer and follows the "Process Overview" narrative strategy. This means after the introduction, it jumps straight into providing the step-by-step breakdown of how to maintain one's health and nutrition during a pregnancy. This narrative strategy allows the organization to deliver a large amount of information as a clear sequence within a short amount of time.

In contrast to the auditory elements of the first video, this one opts for the usual voice-over narration to provide information and is supplemented by an upbeat background music giving the video a cheerful setting. From the very beginning, the narrator introduces herself as "BRAC's doctor apa" (apa translates to elder sister in Bangla but is also used in formal setting to show respect, similar to madam) in order to present herself as a real doctor from BRAC. In her introduction, she states the topic of her talk as "how to stay safe from coronavirus as pregnant and new mothers" and says there is nothing to fear if one acts according to the following instructions. Here, the assumption is that the audience is already interested in the topic and is 
watching this video because they want to learn more. Thus, there is no need to include a dramatic element in the audio or the narrative strategy to draw them into the story as they are scrolling through social media. This is why she directly launches into her list by 24 seconds without spending more time on context creation as the first video did. She sounds friendly but formal, which is how an actual Bangladeshi doctor would speak. This is done to present her as a real expert and not a voice-actor.

In terms of visuals, in these types of instructional explainers, the narrator is usually either seen in their real-life human form or not seen at all. What is unusual about this video is that the narrator is presented onscreen as an animated character (Figure 5.2.1) and remains visible onscreen throughout the full animation (Figures 5.2.1, 5.2.2, and 5.2.3). Therefore, even though this video is closer to common explainer style, it still incorporates the trope of the wise woman/expert in the form of a doctor character. This character is visualized wearing a doctor's apron and holding a stethoscope (Figures 5.2.1, 5.2.2, and 5.2.3). She is also the only character on the screen that is animated. Her facial expressions change while talking and she is constantly gesturing toward the right side of the screen as if giving a presentation. As part of her presentation, different visualizations of the safety procedures appear in white squares simultaneously with her explanation (Figures 5.2.2 and 5.2.3). All the images in the white squares are static with very minimum animation. Only when handwashing is shown (Figure 5.2.2), the hands move slightly and the 20 -second timer flashes on the screen. When showing the don'ts, an animated flashing red cross appears on the upper-left corner of the visual screen (Figure 5.2.3). By making the doctor the only animated and therefore moving figure, it separates her as a real person from the static visuals that she is presenting to the audience. Once again, this simple choice of animating only the doctor and not the other characters seen onscreen enables BRAC to add an expert to the screen without having to show a real-life doctor. The only element missing from the narrative strategy is a call-to-action at the end. The doctor apa ends by telling the parents that if their newborn has corona, they need to continue breastfeeding and consult with a doctor. The usual practice for such an instructional video would be a wrap-up phrase such as "consult your local doctor in case of pregnancyrelated queries and emergencies." The final image (Figure 5.2.4) presents all the collaborating partners of the video. This is an example of the collaborative partnership the local and international NGOs often form with BRAC due to their higher outreach capacities. As shown in Figure 5.2.4, this particular video has been created by BRAC in collaboration with the local NGO Community Clinic Shastho and Sohayota Trust and the French NGO Enfants du monde.

These two videos demonstrate BRAC's hybrid narrative strategy for explainers. They combine common explainer formats with archetypical tropes that have been established previously through MCI. Furthermore, similar to MCI, in the first video the lesson is taught indirectly through the 
experiences of the character in a local story setting. However, the short length of the story and problem-solution narrative strategy make it a unique form of hybrid explainer video. Even though the second video closely sticks to the audio and narrative styles of announcement explainers, it still incorporates hybridity by introducing an animated doctor from BRAC to speak directly to the audience.

\section{Conclusion}

In Bangladesh, the status of women has improved a lot since the 1990s, the "Decade of the Girl Child" (McKee et al., 2004, p. 334). Women are now able to get an education, skills training, and jobs outside the home. This has been due to the collective efforts of the government of Bangladesh and the different national and international NGOs. The constant presence of new media content on television and social media platforms continues to remind the population that this is still a work-in-progress and that there is still much to be done. The two examples from BRAC used here also demonstrate this fact. Although there have been many different campaigns against domestic violence, it remains a common issue. The same is the case for maternal health issues, where some common misconceptions remain. Even though these examples address women's rights communication, the strategies do not necessarily only apply to them. The narrative strategies demonstrated in this chapter can be applied to other topics as well.

NGOs planning on including animated explainers into their communication strategy would benefit from considering the three main components of explainers (i.e., audio, visuals, and narrative strategy) individually. As the narrative strategy includes the design decisions of audio and visuals, this is a good starting point for the organization. This could be chosen from strategies provided in this chapter such as "Meet Bob," "Announcement," "Process Overview," or other common explainer strategies. Next comes the choice for the audio delivery, meaning voice-over narration or dialogue-based storytelling. After that, choosing local archetypes, characters, and other visuals falls into place more easily.

Finally, the narrative strategies used by BRAC provide three valuable takeaways for animated content in development communication overall. The first takeaway is that utilizing locally established characters and tropes provides context and dramatic elements in a very short time. As the audience is already familiar with the characters such as an abused wife or an expert doctor, they can make decisions on what the video content is about. The second is that even when using common explainer narrative strategies, one can customize them with local audio elements, such as explanation delivery in colloquial dialect and local musical scores. This customization also applies to visuals such as colors, backgrounds, and characters. Giving the characters local names is also a good choice. The third takeaway for effective communication is that by considering the learning habits and 
experiences of the audience from animated videos on social media, one can include or leave out certain information. Here, the explainer can work as a gateway to information giving only an overview and then asking the audience to find out more, via the call-to-action. Therefore, it is always important to adjust the narrative strategy to the needs of the local audience. As demonstrated by BRAC's examples, the audience may be open to learning about health topics in the form of lectures but for sensitive topics such as domestic violence one might need a more dialogue-based narrative approach.

\section{Acknowledgements}

The author would like to thank Annkatrin Voos for her assistance with the literature review.

\section{References}

Aghi, M., \& Carnegie, R. (1996). Formative research in the Meena communication initiative. Promotion \& Education, 3(2), 24-27.

Ahmed, S. M. (2008). Taking Healthcare Where the Community Is. The Story of the Shasthya Sebikas of BRAC in Bangladesh. BRAC University Journal, V(1), 39-45.

Akhter, S., Rutherford, S., \& Chu, C. (2019). Sufferings in silence: violence against female workers in the ready-made garment industry in Bangladesh: a qualitative exploration. Women's Health, 15, https://doi.org/10.1177/1745506519891302.

Alam, N. (2021). Positive Geschlechterrollenbilder in UNICEFs MEENA Cartoons. In F. Bruckner, J. Hagler, H. Lang, \& M. S. Reinerth (Eds.), In Wirklichkeit Animation ... Beiträge zur deutschsprachigen Animationsforschung. Springer VS.

Auger, G. A. (2013). Fostering democracy through social media: Evaluating diametrically opposed nonprofit advocacy organizations' use of Facebook, Twitter, and YouTube. Public Relations Review, 39(4), 369-376.

BRAC. (2017, October 19). Rabeya's right to a happy life, free of abuse [Video]. YouTube. https://www.youtube.com/watch?v=cbC85e0v0ms

BRAC. (2020, August 18). গর্ভবতী ও নতুন মায়েরা থাকুক নিরাপদদ । BRAC [Video]. YouTube. Retrieved from https://www.youtube.com/watch?v=BnOu5IVUy0c

BRAC (a). BRAC Vision, Mission, and Values. BRAC. Retrieved from http://www. brac.net/vision-mission-values\#: :text=Our $\% 20$ mission $\% 20$ is $\% 20$ to $\% 20$ empower,men \%20to\%20realise\%20their\%20potential.

Chatterjee, N., Azam, S. A. H., Joshi, A., Talwar, G. S., Hira, N., Nair, S., \& Aggarwal, R. (2020). UNICEF Bangladesh Formative Evaluation of Meena Communication Initiative 2019. Retrieved from https://www.unicef.org/evaldatabase/files/Meena_ Communication_Initiative_Evaluation_Report_Vol_I.pdf

Chesterton, P. (2004). Evaluation of the Meena communication initiative. Kathmandu: UNICEF.

Chowdhury, A. M. R., \& Bhuiya, A. (2004). The wider impacts of BRAC poverty alleviation programme in Bangladesh. Journal of International Development, 16(3), 369-386. https://doi.org/10.1002/jid.1083

Fishman, E. (2016). How Long Should Your Next Video Be? Wistia. Retrieved September 13, 2020, from https://wistia.com/learn/marketing/optimal-video-length 


\section{Naima Alam}

French, K. (2017). How to Figure Out the Right Length for Your Motion Graphics. Retrieved September 13, 2020, from https://www.columnfivemedia.com/how-tofigure-out-the-right-length-for-your-motion-graphics

García-Orosa, B., \& Pérez-Seijo, S. (2020). The Use of 360 Video by International Humanitarian Aid Organizations to Spread Social Messages and Increase Engagement. VOLUNTAS: International Journal of Voluntary and Nonprofit Organizations, 31(6), 1311-1329.

Human Rights Watch. (2020). "I sleep in My Own Deathbed" Violence against women and girl in Bangladesh: Barriers to legal recourse and support. Retrieved from https:// www.hrw.org/report/2020/10/29/i-sleep-my-own-deathbed/violence-againstwomen-and-girls-bangladesh-barriers\#

IMF. (2020). World Economic Outlook Database [World Economic and Financial Surveys].

Retrieved from https://www.imf.org/en/Publications/WEO/weo-database/2020/October/ weo-report?c=513,924,534,518,558,524,\&s=NGDP_RPCH,NGDPD,NGDP_D,N GDPRPPPPC,PPPSH,NID_NGDP,TM_RPCH,TX_RPCH,LUR,LP,\&sy=2011\&ey= 2021\&ssm $=0 \& s c s m=1 \& s c c=0 \& s s d=1 \& s s c=0 \& s i c=0 \&$ sort $=$ country \&ds $=. \& b r=1$

Internet World Stats. (2020). Asia internet use, population statistics data and facebook data - June 30, 2020. Retrieved September 12, 2020, from https:// www.internetworldstats.com/stats $3 . h$ tm

Islam, M. Z. (2020, July 09). Bangladesh lags behind Asia Pacific peers in telecom services: GSMA. The Daily Star. Retrieved from https://www.thedailystar.net/business/ news/bangladesh-lags-behind-asia-pacific-peers-telecom-services-gsma-1927249

Ivanova, S. (2017). Using explainer videos to teach web design concepts. The 13th International Scientific Conference eLearning and Software for Education.

Jung, C. G. (1970). Archetypes and the collective unconscious.

Kachan, D. (2020, February 19). 5 Tips for Producing a Killer Explainer Video. Explain Ninja. Retrieved from https://medium.com/explain-ninja/5-tips-for-producing-akiller-explainervideo-81ebae9dc802

Kenyon, H. (2001). Animation for development in south Asia. Animation in Asia and the Pacific, Sydney: John Libbey, 225-237.

Kilroy, J. (2018, June 29). How to Write a Great Explainer Video Script in 8 Simple Steps. Columnfivemedia. Retrieved from https://www.columnfivemedia.com/ easy-guide-to-writing-successful-explainer-video-script

Krämer, A., \& Böhrs, S. (2017). How Do Consumers Evaluate Explainer Videos? An Empirical Study on the Effectiveness and Efficiency of Different Explainer Video Formats. Journal of Education and Learning, 6(1), 254-266.

Mayer, R. E., \& Moreno, R. (2002). Animation as an aid to multimedia learning. Educational Psychology Review, 14(1), 87-99.

McCarthy, M. (2018, February 15). 10 FACTS ABOUT BRAC, THE WORLD'S LARGEST NGO. Retrieved from https://borgenproject.org/10-facts-about-brac/

McKee, N., Aghi, M., Carnegie, R., \& Shahzadi, N. (2004). Cartoons and comic books for changing social norms: Meena, the South Asian girl. In A. C. Singhal, Micheal J.; Rogers, Everett M.; Sabido, Miguel (Ed.), Entertainment-education and social change: History, research, and practice (pp. 331-349). Lawrence Erlbaum Associates, Publishers.

Nath, S. (2002). The Transition from Non-Formal to Formal Education: The Case of BRAC, Bangladesh. International Review of Education, 48(6), 517-524. Retrieved from http://www.jstor.org/stable/3445505 
NGO Advisor. (2021). Top 200 World: BRAC No. 1. NGO Advisor. Retrieved February 15, 2021, from https://www.ngoadvisor.net/ong/brac

Oentoro, A. (2018, June 28). The Ultimate Cheatsheet to Explainer Video Scripts [INFOGRAPHIC]. Breadnbeyond. Retrieved from https://breadnbeyond.com/ explainer-video/explainer-video-script-cheatsheet/

Quayyum, N. (2019). Women workers in Bangladesh's ready-made garment industry: Building an infrastructure of dissent. Journal of Labor and Society, 22(4), 835-852.

Rashid, S. F. (2000). Providing sex education to adolescents in rural Bangladesh: Experiences from BRAC. Gender \& Development, 8(2), 28-37. https://doi.org/10. 1080/741923625

Raza, W. A., Das, N. C., \& Misha, F. A. (2012). Can ultra-poverty be sustainably improved? Evidence from BRAC in Bangladesh. Journal of Development Effectiveness, 4(2), 257-276. https://doi.org/10.1080/19439342.2012.686046

Singhal, A., \& Rogers, E. M. (2004). The Status of Entertainment-Education Worldwide. In A. Singhal, M. J. Cody, E. M. Rogers, \& M. Sabido (Eds.), LEA's communication series. Entertainment-education and social change: History, research, and practice (pp. 3-20). Lawrence Erlbaum Associates Publishers.

Slater, M. D. (2002). Entertainment education and the persuasive impact of narratives. In M. C. Green, J. J. Strange, \& T. C. Brock (Eds.), Narrative impact: Social and cognitive foundations (pp. 157-181). Lawrence Erlbaum Associates Publishers.

Slater, M. D., \& Rouner, D. (2002). Entertainment - education and elaboration likelihood: Understanding the processing of narrative persuasion. Communication Theory, 12(2), 173-191.

Stiching BRAC International. (2019). Annual Report: Consolidated financial statements 2019 [Annual Report]. Retrieved from http:/www.brac.net/images/ reports/2019/STICHTING-BRAC-INTERNATIONAL.pdf

The Daily Star. (2020, March 6). Brac number one NGO in the world for 5th consecutive year. The Daily Star. Retrieved from https:/www.thedailystar.net/world/ news/brac-number-one-ngo-the-world-5th-consecutive-year-1876957

UNICEF Bangladesh. (2010, October 10). Meena: Count Your Chickens (English) [Video]. YouTube. Retrieved from https:/www.youtube.com/watch?v=_woiuqhasRY

Verstiuk. (2020, September 15). 5 Easy Script Templates-Promotional Video (+Examples). Verstiuk Production. Retrieved from https://verstiuk.com/blog/5-script-templatespromotional-video/

Waters, R. D., \& Jones, P. M. (2011). Using video to build an organization's identity and brand: A content analysis of nonprofit organizations' YouTube videos. Journal of Nonprofit \& Public Sector Marketing, 23(3), 248-268. 
$\because$ Taylor \& Francis

Taylor \& Francis Group

http://taylorandfrancis.com 
Part II

Case Studies of Social

Change NGOs 
$\because$ Taylor \& Francis

Taylor \& Francis Group

http://taylorandfrancis.com 


\section{The Development Workshop Cooperative Giving Voice to the Voiceless}

\section{Advocating for Seasonal Agricultural Workers in Turkey}

\section{Emel Ozdora Aksak and Daniela V. Dimitrova}

Non-governmental organizations (hereafter NGOs) are called upon to tackle social and development related challenges in developing countries where governments may be dealing with social, political, and financial constraints instead of addressing needs of vulnerable and disadvantaged communities or bringing about positive social change. Since the 1990s, NGOs have been expected to mobilize their supporters and stakeholders at the global level, especially by International NGOs (INGOs), which have achieved substantial gains in areas such as "women's rights, the environment, HIV/AIDS, and the banning of landmines" through effective programs and advocacy (Hortsch, 2010 , p. 130). The main goal of development-focused NGOs is to articulate and advocate for the interests and concerns of disadvantaged groups. "Development NGOs have become regular participants in discussions of popular participation and social sector projects, areas in which they are considered to have special expertise or delivery capacity that makes it necessary to listen to their concerns" (Nelson, 2000, p. 479). Yet, NGO advocacy for social change can remain "hidden" without much public recognition or scholarly attention.

NGOs have developed a deep understanding of the importance of information and communication tools in advocacy, targeting not only key policymakers but also media discourse as well as public opinion (Jordan \& van Tuijul, 1998). Engaging in constructive and supportive relationships with media institutions and effectively using traditional and digital media is also considered to be another major challenge for NGOs. Ihlen et al. (2015) note additional challenges such as the availability of financial and human resources, understanding shifting target audiences, and strategizing political goals (whether to advocate or remain neutral). In addition, effective advocacy for increased awareness and policy change has been another major challenge for NGOs. Sogge (1996) underlines lack of reflexivity and being self-critical in assessing the significance and impact of their own advocacy efforts, and Nelson (2000) suggests that such criticisms "should prompt NGOs to a more deliberate and consistent assessment of advocacy projects" (p. 486).

DOI: $10.4324 / 9781003188636-9$ 


\section{Emel Ozdora Aksak and Daniela V. Dimitrova}

NGO advocacy has also followed a similar pattern in Turkey. One NGO established in Turkey specifically focusing on marginalized communities is the Development Workshop Cooperative (DWC). The DWC develops and implements programs and projects in the field of governance, social development, education, and children and youth for and together with public, civil, and private sector as well as academics. Areas of interest and strength of the DWC include the following: seasonal labor migration with a focus on migrants and disadvantaged populations; elimination of child labor; genderbalanced local development; inclusive education; and aging. In addition, the DWC can be considered one of few local NGOs in Turkey working to provide a voice to the most disadvantaged populations-nomadic and seminomadic groups, specifically the Syrian Doms and Abdals, whose members are typically ignored by the Turkish and Syrian communities alike and tend to fall under the radar of most mainstream media due to the lack of access to this specific ethnic group.

Turkey has housed a large population of various Roma communities, Doms, Roms, and Loms, due to being a transition point in their migration routes from Northern India. The Doms living in Iraq, Iran, Syria, Lebanon, Jordan, Egypt, and Turkey constitute the Roma communities in the Middle East today. The Roms starting from India and Pakistan and following the course of Anatolia and the Black Sea to reach Europe and Russia, and then to North America, constitute only one branch of Roma in Turkey. The Loms crossing the Caucasus Mountains to reach Azerbaijan, Iran, Armenia, and Turkey constitute the rest of the Roma communities living in northern Turkey (Kalkınma Atölyesi, 2020). Abdals, on the other hand, are non-Sunni Turkish-speaking Muslims with an itinerant lifestyle and are known for their talents and abilities in Music. The DWC team makes a point of ensuring that these groups are seen as disadvantaged and vulnerable instead of being referred to as marginalized as this implies more marginal and politicized communities.

With these suggestions in mind, the overarching questions we try to address in this qualitative case study is the interplay of one specific NGO not only with the communities they work closely with but also the relationship dynamics with other NGOs, government institutions, corporations, and mass media to develop a deeper understanding of different levels and components of NGO advocacy to bring about social change. Over the last decade, NGOs have occupied the front pages of mainstream newspapers and have been the focus of academic; yet "only very few publications research the interplay of (different) TSOs [Third sector organizations], particularly with regard to cooperation and possible competition among the organizations" (Garkisch et al., 2017, p. 1870). Thus, the capacities and capabilities of the DWC are examined in detail to provide much needed NGO advocacy context and reveal a network of relationships NGOs are involved in.

Consequently, this chapter focuses on (1) investigating the advocacy efforts of the DWC and (2) evaluating their effectiveness in giving a voice to 
the most disadvantaged and vulnerable groups among Syrian migrants and their causes. Thus, the main goal of the chapter is to reveal the communication and advocacy efforts of this innovative NGO to help create awareness about disadvantaged communities in Turkey and to foster social change and development. Approaching the issue from a qualitative perspective to develop a deeper understanding of the work they conduct and possibly the challenges they face, this case study is supported with in-depth interviews with NGO officials to understand their impact on social change and development within the Turkish context. The case study presented in this chapter, however, can be transferred to other contexts at similar stages of political and economic development who are trying to better integrate disadvantaged groups and create a strong and more diverse civil society presence.

\section{The Importance of NGOs in Turkish Civil Society}

As a critical component of civil society, NGOs establish, manage, and sustain relationships with mainstream media institutions as well as government institutions, other NGOs, and international/ supranational organizations such as the European Union or the United Nations. Their main goals usually fall under several areas, such as understanding and addressing the concerns and challenges faced by disadvantaged populations (Jordan \& van Tuijul, 1998), raising awareness and lobbying (Ihlen, Figenschou, \& Larsen, 2015), engaging in legal and community activism and mobilization (Paker 2019), and implementing advocacy activities on behalf of their beneficiaries. Although we may know their activities and projects in the already mentioned areas, the literature lacks studies reflecting the perspectives and voices of the NGOs themselves. Indeed, Ihlen et al. (2015) have pointed out the need to study how civil society actors practice advocacy by discussing strategies they use and challenges they face. Garkish, Heidingsfelder, and Beckmann (2017) also corroborate that investigating the relationships in the third sector and interdependencies between different actors is a worthwhile area of research.

Since the 1980s, the civil society scene in Turkey has become more vibrant partly due to increasing civic activism among the population as well as civil society expansion, which has its roots in the 1920s with the establishment of the Turkish Republic. Currently, Turkey fosters an active NGO scene, especially since the arrival of Syrian migrants in 2011, that focuses on issues such as "ecological sustainability, climate change, gender inequality, human rights, education, democratic participation, identity articulation, coexistence, and refugees" (Paker, 2019, p. 10). Although the AKP government's post-2016 coup attempt purges have negatively impacted oppositional civil society voices, NGOs still strive to create social change despite political and social pressures. Recent statistics by the Turkish Ministry of Interior show that there are 119,731 active NGOs that are currently operating within the country (Ministry of Interior, n.d.). 


\section{Emel Ozdora Aksak and Daniela V. Dimitrova}

The arrival of Syrian migrants has resulted in many service-based and rights-based organizations actively engaging in various projects aimed at helping disadvantaged populations in Turkey. One of the challenges for NGOs in Turkey has been the competition for resources-especially since 2015, when the Syrian refugee initiatives received funds from the European Union and turned the NGO scene in Turkey into a lively beehive. Despite being not-for-profit establishments, NGOs are increasingly forced to fight for limited resources, resulting in their corporatization. While NGOs constantly express their openness to cooperate, competition stifles the potential for collaborative communication and information sharing. "There is a general reluctance of organizations to share information, especially information that is considered proprietary or of significant value to organizations typically competing for funding from the same sources" (Maiers, Reynolds \& Haselkorn, 2005, p. 89).

Many civil society organizations strive to take on an advocacy role. Beck (1997) states that effective advocacy needs to influence the worldviews of people to potentially change/reinforce governmental or corporate policies in their favor. It is about coming together and combining your forces to influence policymaking processes by bringing an issue to the national agenda (Ortmann, 2012). But advocacy is not merely about changing corporate or government policies. Advocacy starts with empowering a community. According to Jordan and Van Tuijl (2000), "The underlying function of advocacy is often to enhance the self-respect of weaker communities, to improve their self-confidence, constitute integrity and promote mutual trust: all essential ingredients to develop a healthy community" (p. 2052). We strive to understand whether the DWC is able to enhance communitybuilding through advocacy.

\section{The Development Workshop Cooperative}

The DWC was founded as a not-for-profit cooperative by a visionary group of young professionals in 2004 to work on social development projects in Turkey. The organization was established to fill a gap in Turkey's development policies and to contribute to the sustainability, implementation, and success of projects of all sizes. Their structure as a cooperative is unique for an NGO as this is not a common choice for an organization in the area of social change and development in Turkey or in the world. Their work structure envisages the establishment of a tradition that produces shared experiences and consists of workshops instead of programs, where each workshop has a thematic focus integrating a human rights and child rights based, gender equality focused social development approach. All initiatives abide by the organization's mission and vision statement as well as rules and procedures required for a social enterprise cooperative.

Over time, the organization has also embraced the concept of sustainable development and the fact that social, economic, and environmental 
sustainability should be included in general development policies and projects of all sizes. Starting with the United Nations Sustainable Development Summit held in Rio in 1992, international efforts to ensure sustainability in all areas continue since the announcement of the United Nations Millennium Development Goals. These objectives include elimination of extreme poverty, hunger, and gender discrimination, improving maternal and child health, increasing women's effectiveness, ensuring environmental sustainability, and global cooperation for development. Thus, the main objectives of the DWC overlap with the Millennium Development Goals of the United Nations.

To achieve these goals, the DWC has a working group of professionals with specific areas of expertise such as social anthropologists, sociologists, physical anthropologists, international relations specialists, biologists, and forestry experts. Relying on this group expertise, the DWC develops and implements programs in various fields such as governance, social development, education, and children and youth for and with non-governmental organizations NGOs and relevant producer unions based on field research, face-to-face interaction with beneficiaries and responsible institutions, and experts of the subject. Additionally, the DWC conducts awareness-raising and partnership-building activities with the participation of local actors (other civil society organizations, public agencies, decision-makers, leaders, affected groups, etc.). Their goal is to empower youth, women, educational actors, producers, community members and leaders, and disadvantaged groups to participate in decision-making processes, to learn their rights, and possibly initiate their own solutions.

Over the past 20 years, DWC's agenda in Turkey focused on private, rural, and urban development as well as international integration. In this context, DWC planned and implemented a series of development projects with international aid:

- Project on International Seasonal Agricultural Migration in Turkey (June 2015-May 2016) with financial support from the Embassy of Netherlands

- Mitigating Child Labor Risks in Cotton (October 2015-November 2016), an action-based collaborative with the Fair Labor Association to investigate child labor issues in upstream cotton supply chains in Turkey, with financial support from the Embassy of Netherlands

- Improving the Health and Protection of Vulnerable Syrian and Marginalized Migrant in Southern Turkey Project (May-November 2016), in cooperation with the international non-government organization GOAL, with financial support from the European Commission's Directorate-General for Humanitarian Aid and Civil Protection- European Civil Protection and Humanitarian Aid Operations (ECHO) and the EU Humanitarian Assistance Fund

- Reducing Legal and Institutional Gaps in Prevention of Child Labor in Seasonal Agriculture Project (September 2017-August 2018), with 


\section{Emel Ozdora Aksak and Daniela V. Dimitrova}

financial support from the Embassy of Netherlands, the UNICEF Program Cooperation Agreement, and the UNICEF Program on Elimination of Child Labor.

As these projects demonstrate, the DWC has worked closely with various entities, including other NGOs, governmental agencies, foundations, international aid agencies (e.g., UNICEF or the International Labor Organization), but also with for-profit corporations (undisclosed due to confidentiality agreements). The NGO's work mainly falls under local development programs, research and capacity-building, promoting the cooperative movement, apiculture, seasonal labor migration, and tackling child labor. Partnering with local leaders and community-based organizations is a good model for encouraging active participation in a democratic manner that contributes to developing new approaches in the area of social development, not only in Turkey but also globally.

Focusing on a specific NGO, this research tries to uncover the communication and advocacy efforts of the DWC working with disadvantaged and vulnerable communities in Turkey by understanding the specific strategies they employ and the main challenges they face in fostering social change. In this chapter, we investigate the following research questions:

$\mathrm{RQ}_{1}$ : What strategies does the Development Workshop Cooperative employ in order to advocate and communicate on behalf of disadvantaged communities such as seasonal agricultural workers in Turkey?

$\mathrm{RQ}_{2}$ : What are the main challenges the Development Workshop Cooperative faces within Turkey's sociocultural context?

\section{Method}

This qualitative case study focuses on the advocacy strategies and challenges of one particular NGO, the DWC, within the Turkish context. Facilitating the comprehension of a specific phenomenon, a case study includes the detailed study of its processes and actors involved to describe, explain, predict, or control components at an individual, group, or organizational level (Farquhar, 2012; Gagnon, 2010; Woodside \& Wilson, 2013). Case study findings provide in-depth insights about context studied, answering how, when, and why questions (Yin, 2009). This study utilizes the single case study method to understand how NGO advocacy is conducted in Turkey and the challenges the DWC faces. We analyzed secondary data about the DWC and all the activities and projects they have been involved in since its establishment in 2004. However, we believe that the secondary data needs to be supported and complemented with primary data to allow for the discovery of rich data. We conducted semistructured interviews due to their flexible nature (Britten, 1999), which allowed participants to freely and openly reflect on their perspectives and meanings (Denzin \& Lincoln 2005), reveal points of view 
(Kvale, 1996), and shed light to areas that have not been initially thought of by the researcher(s) (Gill, Stewart, Treasure \& Chadwick, 2008).

The interviews were scheduled and conducted with key DWC personnel: one of the co-founders and social development expert, Ertan Karabiyık, and child rights expert, Sinem Sefa Bayraktar. Originally a forest engineer by training and previously a full-time consultant for UNICEF Turkey Country Office, Ertan, who is the coordinator of the DWC, has over 30 years of experience in social development studies, specifically focusing on education of migrant children, seasonal agricultural workers or other vulnerable migrant populations, and the Roma and Syrian Dom communities in Turkey. Sinem also has 15 years of UNICEF Country Office experience in Turkey working on child protection and youth development projects and has been actively working for the DWC for the last 5 years as a project manager and consultant. She also works as a consultant for various EU technical projects. Both informants define themselves as human rights activists and advocates. In terms of contractual agreement, they are both expert consultants as their position in the NGO is project budget dependent due to the cooperative structure of the NGO, which does not allow for the hiring of many full-time staff. The interviewing process started in the NGO offices to ensure that we get to see their working environment and have access to all the reports and research that they have. We also collected a set of their publicity materials and reports for later examination.

Interview Participants

Ertan Karabiyık

DWC Co-founder, Coordinator and Social Development expert

Sinem Sefa Bayraktar DWC Project Manager and Child Rights expert

The interview questions were approved by the ethics committees and review boards of the researchers' institutions before conducting the interview to ensure confidentiality of participants and ethical research procedures (Beck \& Manuel 2008). The initial interview with the two key informants was conducted in English (with some Turkish translations to ensure smooth translations) in September 2019 and lasted about two and a half hours. As suggested by Britten (1999), we started with simpler questions such as asking about their experience in the field and how they decided to be a part of the NGO in order to build rapport, and slowly moved to more sensitive topics such as the challenges they face and how they view working with other organizations/ institutions. The participants were also asked to introduce themselves and describe their roles and responsibilities and later asked to define the specific populations they work with and share what they consider to be their major achievements. Other questions asked were about specific projects the organization has implemented and description of an ongoing project as well as 


\section{Emel Ozdora Aksak and Daniela V. Dimitrova}

their advice for newcomers in the field. Participants were also asked about their relationships with media organizations and to describe their communication and advocacy efforts in more detail. A two-person research team also proved to be instrumental in ensuring that comprehensive and representative data were collected (Hammersley \& Atkinson 1995). The follow-up and fact-checking interview was organized in March 2020 and this also lasted about two hours. Here, a draft was shared with both interviewees and given the opportunity to provide feedback and add details.

\section{Findings}

\section{Mission and Experience}

Both Sinem and Ertan define the DWC as a "rights"-based NGO-not a service-based one. Both are primarily interested in evidence-based advocacy, awareness-raising, capacity-building, training, and policy development. So, they do not engage directly with refugee populations or other vulnerable communities for service provision, only when they are in the field doing research or working on piloting programs or initiatives. DWC's unique social cooperative structure makes them different from other local NGOs. As a not-for-profit cooperative, and consistent with their mission, DWC focuses on doing research and engaging in evidence-based advocacy to help improve the lives of the most vulnerable and disadvantaged communities living in Turkey (Figure 6.1).

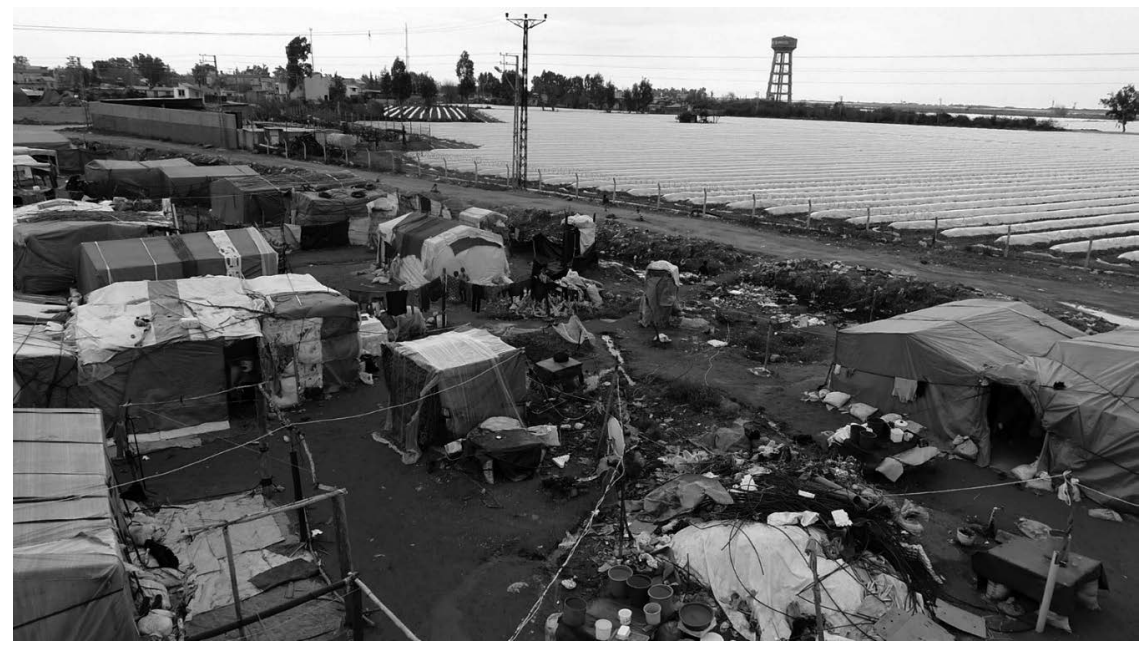

Figure 6.1 Seasonal migratory agricultural workers' temporary tent settlement beside the pepper field in Adana Province, Turkey.

Source: Courtesy of DWC (2018). 
Although Syrian refugees arrived in Turkey in 2011, the DWC started working with this population four years later. At the time, the Turkish government was not yet focusing on refugees only, so the initial projects in these areas focused on migrants as a unified group. Around the same time, they also started seeing a change in the makeup of agricultural workers in Turkey as Syrians were replacing Turkish citizens in seasonal agricultural work. DWC says that currently most of the labor force in seasonal agricultural work has been increasingly undertaken by migrant communities because these jobs involve very hard work and "no one really wants to do it." They define seasonal agricultural work as the bottom of the pit in terms of labor. Ertan states that "the easiest jobs to integrate and find are the informal market, so they integrate easily in these areas. These jobs are invisible, uninspected, dynamic, temporary and are high in demand."

Today, migrants have largely replaced seasonal agricultural work in Turkey. In 2016, Turkey made a deal with the EU to support Syrian refugees locally, releasing funds by ECHO. In order to implement projects supported by this funding scheme, international organizations had to work with local NGOs. Ertan complains about the unbalanced working agreements, "We were doing the work, but we were considered only to be suppliers," which created many authority, identity, and visibility challenges for most of the smaller local and national NGOs working as implementing partners of large international organizations in Turkey.

\section{Communication Strategies}

The DWC is well known for producing exemplary advocacy materials and lots of publications such as reports, maps, newsletters, and booklets. After 2016, they have been involved in many platforms not only at the national but also at the global level. For example, they participated in the Global Compact for Migration Summit in 2018 to showcase Turkey's experience, to create visibility around seasonal workers and child labor among the migrant community in Turkey, which consists primarily of Syrians, Georgians, Afghan, Azeri, Iranians, and Iraqis. More recently, the DWC team also attended the Regional Civil Society Consultation on the implementation of global frameworks on migration in the MENA region, organized by CCRM (Cross-Regional Center for Refugees and Migrants) in Istanbul, Turkey, in December 2019 to talk about the challenges faced by disadvantaged migrant communities. The meeting brought together actors from various sectors, including migrant organizations, trade unions, women's organizations, faith-based organizations, and media organizations from the Middle East and North Africa who support the implementation of global frameworks on migration. The other recent event that DWC attended was the Civil Society Day of the Global Forum on Migration and Development in January 2020 in Quito, Ecuador, to showcase the situation of migrants and Syrian communities in Turkey. 


\section{Emel Ozdora Aksak and Daniela V. Dimitrova}

The interviewees stress that Syrian workers and especially Doms-the Roma population of Syria-are the most disadvantaged and the most closed and scared community among all vulnerable populations. They are discriminated against by almost all other groups, including Syrian nationals. The Doms are even afraid of being murdered. But despite all these challenges and the support needed to aid them, it is very hard to communicate with these communities as they are afraid to open up to outsiders, and also have a language barrier as they speak a very narrow dialect that is used only by their community. Ertan believes that knowledge of language and their cultural characteristics can be a major challenge for organizations that want to support these seasonal agricultural workers and nomadic communities:

Some organizations that work for these disadvantaged communities need to improve how to communicate with these people, how to act near them, or what to say exactly. They feel alien, they feel distant, they freeze. They don't receive any supervision or training about relationship building and communication abilities.

To give an example of the DWC's approach, the organization does not use translators when they are in the field. They work together with people who speak Arabic and/or Kurdish to communicate with these groups. Going there with a translator has a different effect. Trust is a very important factor for the DWC to be successful in the field. Even Sinem, who has worked in this field for more than 15 years says, "These people are testing you all the time, if they feel like you don't understand them or how they live, they shut down, they don't speak to you, share details or even tell the truth.” The DWC team highlights the need to learn these skills, methods, and tactics to communicate with these communities in order to engage with them.

They believe that advocacy tools need to be developed to help support these disadvantaged communities. One of the things they do is to communicate in the language of the populations in need. They produced information booklets in Arabic and Kurdish for the Syrian agricultural workers. "However, the Kurdish speaking community within Syrian worker groups don't know how to read Kurdish texts. They said, give us the Arabic brochure so we can ask our neighbor to read it for us." Hence, one of the accomplishments of the DWC was to first create awareness about the reality of Dom communities, to show that typical bureaucracy does not apply to them and to organize information sessions with community members about basic services, social rights, health, education, disability rights, and humanitarian aid. They also advocated for the setting up of public information phone lines in different languages to provide information for these communities. Ertan is very passionate about this achievement:

We were successful in making the authorities understand the reality of these people. We believe in face to face communication, in real effects. 
This is why we go to panels, we talk with people, and others call and invite us to participate in meetings and events, we even go as speakers and give lectures in universities.

For Sinem, “an organization's role is not just highlighting the problems, because then you are exhausting people. Creating awareness about problems is not enough. People need models, they want to see solutions." They say that they are too small for large-scale communication campaigns and instead they focus on advocacy with the relevant groups and authorities. Therefore, publicity materials have been crucial for the Development Workshop since they were first established, and they put a lot of thought and effort in producing high-quality and relevant advocacy materials. These reports also help create visibility for their initiatives and about them as social development experts. They say that they get contacted by other organizations quite regularly, as a result of word of mouth networking, which is very effective for them. Also, smartphones and WhatsApp groups have proven useful for networking and keeping in touch. Ertan says, "we need to learn and be more effective in info sharing and dissemination."

The DWC also has a unique approach when it comes to its publications. Their publications do not contain logos on the cover but only a small one on the back. Sinem explains the rationale behind this decision:

It is about the target groups and the cause-we don't want our logo, we don't want visibility for DWC or the experts. We want others to use the information, tools, methods. For example, we highlight major themes such as decent work in seasonal agriculture, child rights, school climate, etc.

Quite simply but also unconventionally, they do not want to showcase ownership of these advocacy materials that they produce. For the NGO, the contents of the report, the research, and field experiences are important. In addition, and again very unconventionally, their publications are not copyrighted, they become public property once published. This decision itself is a key advocacy strategy as they want other organizations to use the information from the reports and share their research, "and perhaps take our approach as a role model for information sharing," Sinem says smiling hopefully. For her, "you have to think outside of the box and resist the system if you want real change."

Figure 6.2 shows a map targeted to render the deprivation and discrimination migrant seasonal agricultural workers face every day visible in order to build a sustainable, participatory, democratic, and transparent social development that respects and protects human rights of all habitants of Turkey. This map was used not just by the DWC, but also by various UN agencies, international organizations, including ECHO, Goal Global, rights-based and humanitarian-assistant NGOs in Turkey, and academicians to stimulate 


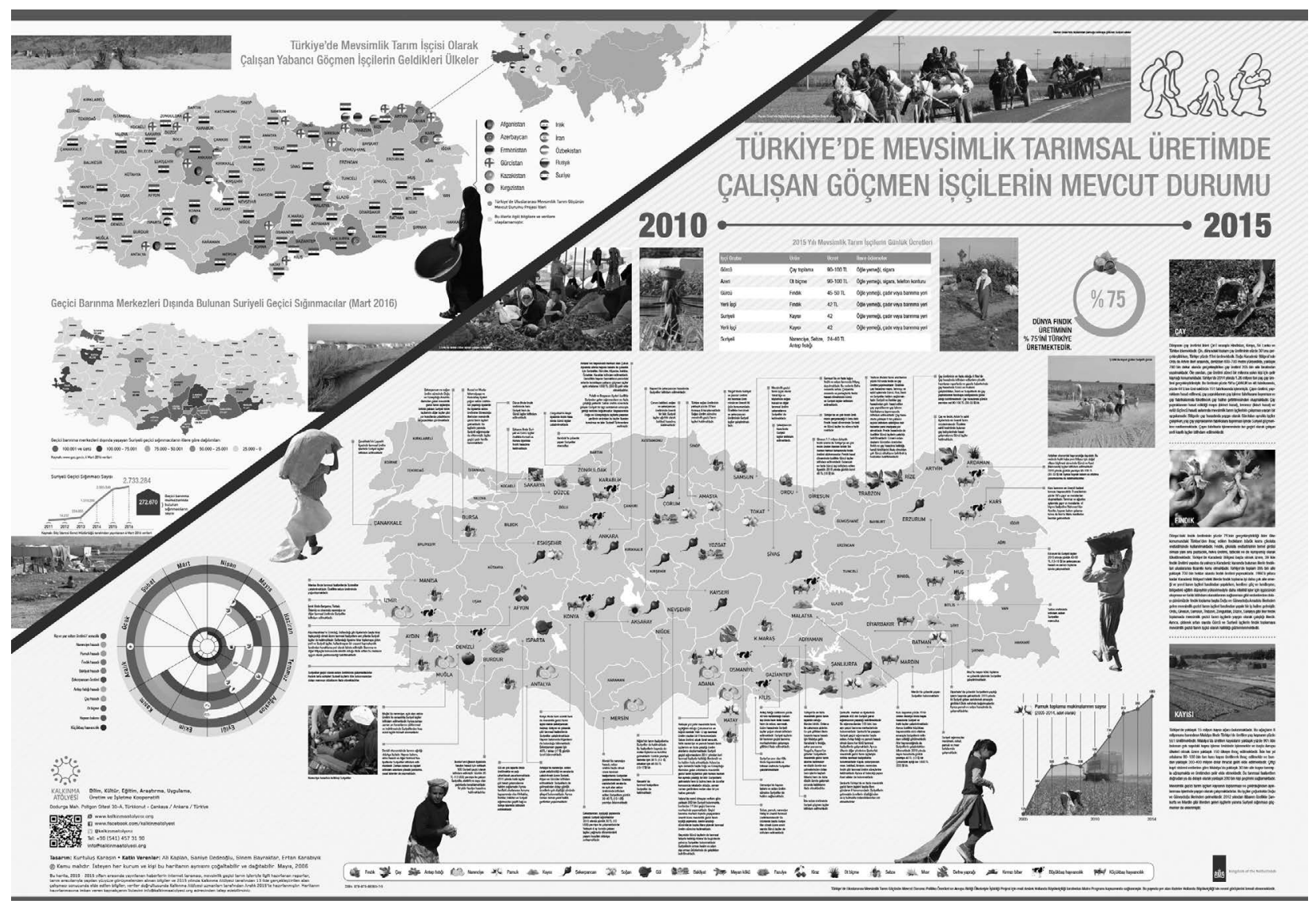

Figure 6.2 Situation analysis of migrant workers in seasonal agricultural production in Turkey (2010-2015).

Source: Courtesy of DWC. 
action with evidence-based advocacy and result-oriented policy tools to prevent violation of migrants' basic human rights and improve their living and working conditions.

We also discussed the role of media relations with Ertan and Sinem. According to them, the lack of independence of traditional media outlets in the country has been a challenge in recent years. However, social media and digital platforms are increasingly becoming more important and effective. Yet, although they realize the power of these platforms, they remain weak at using social media strategically because of the lack of human resourcesrelevant staff that would be required to manage these accounts. Sinem explains:

We can't really pay for this person, plus we don't have permanent staff-it is not our model. Sometimes we hire communication or advocacy experts as part of short projects, we specifically write that as a budget item. We also hire a graphic designer for data visualization.

In addition, they are critical of others who only post about what they do, about the ongoing projects or processes. Sinem says, "Sometimes they only post 'we organized that, our ambassador said that, and such. But how did you impact the lives of people with your actions?" For them, publishing information about tangible results, what their specific projects have achieved, is what is truly important. They argue that people in the field need to have the skills, capacity, qualifications, and specializations to understand what the vulnerable communities need, do meaningful work, and achieve change. Sinem, especially, is quite critical of using social media for the sake of keeping an active Facebook account. "Post whatever you want on social media, but you won't have meaningful results." That points to the fact that social media needs to be used strategically and has to be managed by a dedicated person who has digital media qualifications.

\section{Main Challenges and Recommendations}

When asked to list the challenges they face, one of the first things they mention is the need to provide education for the children of these disadvantaged groups. However, they warn against simply relying on traditional solutions. Ertan says, "If you don't develop models for the real and everyday needs of the community-it doesn't make a difference." He suggests that organizations need to develop local level solutions to build capacity of local actors (such as governmental officials, local administrators, NGOs, academicians, etc.) in order to impact the lives of the community.

Another point Sinem highlights, is not to feel pity. "Don't pity these kids or people-you don't want to foster victimization, this is their life, their situation, and life goes on." They immediately mention an international news story about child labor in hazelnut agriculture work in Turkey on the BBC, 


\section{Emel Ozdora Aksak and Daniela V. Dimitrova}

which was also published in the New York Times where they were also asked to comment. "The question we asked is, if there is news about this in an international newspaper does it help the children or not? Will it bring about change, will they go back to school? These are the questions we ask," Ertan says when deciding to go public or not. They try to use such opportunities to engage in advocacy. And Sinem adds, "we also ask, 'if we don't do it who else will do it?' We feel the responsibility. Even if we can change one life!" Therefore, they say they will never go back to their jobs in international organizations. It is hard to impact lives so directly there.

An issue Sinem and Ertan underline as a challenge is the lack of cooperation between civil society organizations. Both find NGOs in Turkey to be too territorial-with collaboration between NGOs or between NGOs and other organizations becoming challenging. They know from personal experience that large international organizations may be hard to work with due to their strict guidelines, detail-oriented procedures, and sometimes too much bureaucracy and paperwork needed. Ertan says, "Our common goals should lead us to work together, to have the same perspective and common sense to cooperate. We need to put aside our institutional identities and focus on the common mission."

When asked about their recommendations for civil society organizations working in social development areas, Ertan is quick to answer. "Pay more attention to Doms and learn how to work with them," is the first recommendation he has as someone who knows the challenges working with the most disadvantaged and vulnerable populations. Sinem jumps in next and underlines the need for increased collaboration:

Partnerships with other organizations is required for increased impact. We need to combine our strengths and know-how to gain new skills. It should not be limited to just project- or activity-based partnerships, where we implement a training or produce a research report for them.

Ertan and Sinem believe that they should work together starting from the beginning of the process or engage in effective teamwork based on their respective expertise or terms of reference. Another point they highlight is the need for stronger relations with the government. DWC has slowly started to work with the government because the government has not been very keen on working with the civil society and Ertan believes that this needs to change. He also states that it is starting to change as the government has begun collaborating with civil society organizations at the local level, where they do municipality level info sharing and collaborations. He hopes to see this change in the next couple of years. Ertan says:

At the end of the day, public institutions have the roles and responsibilities for provision of human rights and service delivery. For any changes needed you have to either work together with or influence the 
governmental authorities at the central or local levels. What is critical is that civil society institutions should protect their independency, integrity, and authenticity during such collaborations.

A key point we asked Sinem and Ertan about concerned their motivation to keep on working with and for the most disadvantaged and vulnerable communities despite the plethora of systematic challenges and social problems in Turkey. When we asked them how they do self-motivate, the answer was short and simple: "It's a calling." Ertan explains, "going grassroots, being on the field, touching their lives, and being together with local people, NGOs, governments, university students is what feeds us." The most important point here is that he loves his job, and he feels a responsibility toward these people. Passion and perseverance seem to provide the foundation for this very rewarding work. Sinem feels as passionate about her role:

We have a human rights-based role-you feel like you have to do it. We can't close our eyes to these people. We have to go to the field. We must be with these people. We are traumatized in the field-but it is the most fulfilling moments of our lives.

One of the main issues the DWC team highlighted is the notion of feeling at home in the field. They refer to this as: "Gönüllü olmak değil-gönlünü koymak," the direct translation reads as "not just being a volunteer but putting your heart into it"; although so much is lost in translation. DWC team members know the topics, the challenges, the populations, but they place the most value on the trust they have established in their communitybuilding-both sides know what each can deliver. While not always the ideal, these solutions reflect the reality of NGO work and transparency remains crucial for sustainable relationships.

Another important point highlighted by the DWC was their inclination for collective production and solidarity-creating together with no hierarchical structure or position-based authority. They stress that NGOs need to highlight the issues, not the institutions-especially not themselves. However, they see this as an area that requires further collaboration as they argue that as a local and relatively smaller NGO in comparison to international civil society organization monoliths, they should not be just seen as the implementing partner but should be involved in project planning and development from the beginning as they have extensive experience and deeper knowledge of the field. DWC team members feel like the need for cooperation should outweigh the competition for resources and sharing and advocating what is learned from the field should make up the core of the collaboration processes.

However, one of the challenges that come with that is the competition between NGOs regarding ownership and management of projects and for limited funds available. In a study on civil society organizations in Turkey, 


\section{Emel Ozdora Aksak and Daniela V. Dimitrova}

Mackreath and Sagnıc (2017) underline that competition mainly stems from political differences or struggle for funds. This political dimension and proximity to government officials has also been mentioned in our study, but the solution to this challenge could only be a willingness to put aside differences and focus on the needs of these vulnerable communities to bring about change. As stated by Akar and Erdoğdu (2019), especially the issue of refugee settlement and integration requires a unified front with comprehensive and rigorous efforts and strengthened cooperation between policymakers, implementers, and CSOs in various areas, including employment, education, and health.

Another key area for further development and cooperation they highlighted is the need for strengthened government relations for effective advocacy. When it comes to effecting existing policies, working closely with the local actors and decision-makers is critical. Thus, ensuring good relations with the local authorities is important for effective NGO work. Additionally, increasing the visibility of ethnic minorities in the media and creating positive publicity for their target populations emerge as important considerations for nonprofits to bring about social change. When it comes to raising awareness about disadvantaged groups and increasing their acceptance in society, impacting public opinion, in addition to policymakers, is critically important. Consistent with previous studies (e.g., Ihlen et al., 2015,), we also conclude that NGOs are more effective when they engage local media and strategically use various forms of information subsidies, such as targeted press releases and providing striking visuals to facilitate positive media coverage. In addition, the DWC utilizes its communication materials as an advocacy tool by forfeiting copyrights of their materials and making their resources free to share.

\section{Concluding Remarks}

While there are many theoretical definitions of advocacy and step by step how-to guidelines, understanding how advocacy functions in a specific national context by a particular civil society organization working with some of the most disadvantaged and vulnerable communities can provide important lessons, both for academics and practitioners. Our research focused on understanding the communication and advocacy efforts of the DWC to support disadvantaged populations in Turkey. We discussed their main strategies and tried to identify challenges they face in engaging in advocacy and fostering social change.

Both interviewees stated that having a deep understanding of the characteristics and context of the community you work with is critical for success in communication and advocacy. You need to be aware of what their concerns are, what they are afraid of, and what is most important to them. Especially, communicating with them in their native language is critical to establishing trust. Also, sharing research results and advocacy materials with 
all other organizations is important for creating awareness and highlighting issues that need to be addressed, which our interviewees see as the core of advocacy. The DWC believes in communicating about the impact they create, not merely listing the project outputs, and providing models or solutionbased recommendations.

When it comes to the challenges they face, communication management, media relations, and human resources issues are major ones. Because the DWC staff is limited, having someone specifically focused on communicating with media or effectively managing social media accounts is a challenge for them. Any time a communication or visibility opportunity arises, the DWC aims to use it for advocacy to foster change. In addition, providing local and community- or context-specific solutions is something they mention for success and sustainability of programs. Local know-how is valuable, and it needs to be used in advocacy work and communication. Another main challenge is working and collaborating with the government or other international organizations. The DWC team complains about noncollaborative partnerships and not being involved in projects from the planning phase. One solution they suggest is being involved in the project writing phase as they bring in extensive experience and contextual information from the field and thus can provide a realistic snapshot of the needs of these communities.

While we focused on one particular NGO-the Development Workshop Cooperative-that has a unique structure and engages in advocacy on behalf of the most vulnerable migrant populations in Turkey, including the Syrian Dom, we believe the findings of this research are applicable to other similar contexts. Thus, the case study may serve as an inspiration for other similar NGOs but also highlight that despite the many successful projects that the cooperative has implemented in the past, it still faces many challenges in bringing about social change and has areas for further development.

The case study offers in-depth understanding of advocacy work on behalf of disadvantaged and vulnerable populations in Turkey but also cautions against treating all social development NGOs as homogeneous entities. As Sangar and Meyer (2018) stated, "most of the literature only talks about large International NGOs (INGOs) based in the Global North without paying enough attention to other NGOs as well as to the differences between these INGOs" (p. 192). This is why this study highlights a unique NGO formed in a different cooperative structure, which permits the NGO to work effectively for disadvantaged and vulnerable populations. Learning from the experiences of NGOs working with disadvantaged communities contributes to the growing body of literature on advocacy and communication in the third sector. Examining how an NGO has been successful in engaging in community relations and advocacy may also help shed light on challenges and opportunities in the NGO scene in Turkey, as well as provide lessons that might be transferred to other national contexts. 


\section{Emel Ozdora Aksak and Daniela V. Dimitrova}

\section{Acknowledgments}

This project was supported by a Page Legacy Scholar Grant from the Arthur W. Page Center at the Bellisario College of Communications at the Pennsylvania State University, USA. Any opinions, findings, and conclusions or recommendations expressed in this material are those of the authors and do not necessarily reflect the views of the Pennsylvania State University.

\section{References}

Akar, S., \& Erdoğdu, M. M. (2019). Syrian refugees in Turkey and integration problem ahead. Journal of international migration and integration, 20(3), 925-940. https://doi.org/10.1007/s12134-018-0639-0

Beck, U. (1997). Subpolitics: Ecology and the disintegration of institutional power. Organization \& Environment, 10(1), 52-65. https://doi.org/10.1177/0921810697 101008

Beck, S. E., \& Manuel, K. (2008). Practical research methods for librarians and information professionals. Neal-Schuman.

Britten, N. (1999). Qualitative interviews in healthcare. In C. Pope \& N. Mays (Eds.), Qualitative research in health care (2nd ed., pp. 11-19). BMJ Books.

Denzin, N. K., \& Lincoln, Y. S. (2005). The sage handbook of qualitative research (3rd ed.). Sage Publications.

Farquhar, J. D. (2012). Case study research for business. Sage Publications.

Gagnon, Y. (2010). The case study as research method: Implementation guide. Presses de l'Universite du Quebec.

Garkisch, M., Heidingsfelder, J., \& Beckmann, M. (2017). Third sector organizations and migration: A systematic literature review on the contribution of third sector organizations in view of flight, migration and refugee crises. VOLUNTAS: International Journal of Voluntary and Nonprofit Organizations, 28(5), 1839-1880. https://doi.org/10.1007/s11266-017-9895-4

Gill, P., Stewart, K., Treasure, E., \& Chadwick, B. (2008). Methods of data collection in qualitative research: Interviews and focus groups. British Dental Journal, 204(6), 291-295. https://doi.org/10.1038/bdj.2008.192

Hammersley, M., \& Atkinson, P. E. (1995). Ethnography: Principles in practice (2nd ed.). Routledge.

Hortsch, D. (2010). The paradox of partnership: Amnesty International, responsible advocacy, and NGO accountability. Columbia buman rights law review, 40(1). https://ssrn.com/abstract $=1677623$

Ihlen,Ø., Figenschou,T.U., \&Larsen,A.G.(2015).Behind the framing scenes. American Behavioral Scientist, 59(7), 822-838. https://doi.org/10.1177/0002764215573254

Jordan, L., \& van Tuijul, P. (1998). Political responsibility in NGO advocacy exploring emerging shapes of global democracy. Global policy forum. https://www.globalpolicy. org/component/content/article/176/31355.html\#11

Kalkınma Atölyesi (2020). 'Göç Yollarında Görülmeyen Hayatlar; Adana, Gaziantep ve Şanliurfa'da Yaşayan Suriyeli Göçebe ve Yarı-Göçebe Topluluklar ve Adana Ovası'nda Geçici Çadır Yerleşimlerinde Yaşayan Suriyeli Mevsimlik Gezici Tarım İşçileri Durum ve İhtiyaç Analizi. https:/www.stgm.org.tr/sites/default/files/202009/goc-yollarinda-gorulmeyen-hayatlar.pdf. 
Kvale, S. (1996). Interviews: An introduction to qualitative research interviewing. Thousand Oaks, CA: Sage Publications.

Mackreath, H., \& Sagnic, S. G. (2017). Civil society and Syrian refugees in Turkey. Citizens' assembly. Retrieved from https://hyd.org.tr/attachments/article/214/ civil-society-and-syrian-refugees-in-turkey.pdf

Maiers, C., Reynolds, M., \& Haselkorn, M. (2005). Challenges to effective information and communication systems in humanitarian relief organizations. IEEE Proceedings, 82-91. https://doi:10.1109/IPCC.2005.1494163

Turkish Ministry of Interior (n.d.). Number of NGOs. Retrieved from https://www. siviltoplum.gov.tr/dernek-sayilari

Nelson, P. (2000). Heroism and ambiguity: NGO advocacy in international policy. Development in Practice, 10(3-4), 478-490. https://doi.org/10.1080/0961452 0050116622

Ortmann, S. (2012). Policy advocacy in a competitive authoritarian regime: The growth of civil society and agenda setting in Singapore. Administration \& Society, 44(6_suppl), 13-25. https://doi.org/10.1177/0095399712460080

Paker, H. (2019). Practicing coexistence in civil society: Syrian refugees in Turkey. Sabancı University

Istanbul Policy Center. Retrieved from https://ipc.sabanciuniv.edu/wp-content/uploads/ 2019/06/HandePaker_PracticingCoexistence.pdf

Sangar, E. \& Meyer, C. (2018). The enduring value of reliable facts why NGOs have become more influential in conflict discourse. In R. Fröhlich (Ed.), Media in war and armed conflict (pp. 191-217). Routledge.

Sogge, D., Biekart, K., \& Saxby, J. (1996). Compassion and calculation: The business of private foreign aid. Pluto Press with Transnational Institute (TNI).

Woodside, A. G., \& Wilson, E. J. (2003). Case study research methods for theory building. Journal business and industrial marketing, 18(6/7), 493-508. https://doi. org/10.1108/08858620310492374

Yin, R. (2009). Case study research: Design and methods (4th ed.). Sage Publications. 


\title{
7 The Government's Needs Versus the Demands of Labor
}

\author{
A Case Study of Organizing by Labor \\ NGOs in China
}

\author{
Luwei Rose Luqiu
}

The 1995 World Women's Conference in Beijing inaugurated a gender consciousness in Chinese society and contributed to the emergence of the Chinese civil society sector. Importantly, the conference put China's senior party and government leaders in contact with international non-governmental organizations (hereafter NGOs). Some female party cadres even had the opportunity to go abroad to visit the United Nations headquarters and observe how NGOs promote gender equality, bringing back the knowledge to become involved in local NGOs dedicated to gender issues (Wang, 2001). Around the same time, migrant workers moved into China's cities, with young women constituting the majority. NGOs formalized in Beijing to provide services to migrant women workers from rural areas-they created a support network, offered childcare and educational opportunities, and advocated for their rights. With help from international NGOs, these newly found local organizations focused on issues such as women's poverty, education, or domestic violence. For a while, this shaped the public perception of NGO work as synonymous with gender equity work. Later, NGOs from the capitol moved operations to other cities, generating NGO think tanks, and expanding NGO activities to include mobile populations, AIDS, or legal aid, to name a few. The emergence of grassroots organizations and NGOs helped compensate for the government's inability to address social problems during China's transformation from a planned economy to a global market economy. However, unlike in Western societies, many Chinese NGOs are not legally registered due to the high registration threshold set by administrative regulations. This also means that the government does not have accurate information about China's NGO landscape (Liu \& Wang, 2009).

Chinese scholars have defined Chinese NGOs' social functions around resource mobilization, public service, social governance, and policy advocacy (Wang \& Liu, 2009). Some consider the 2008 Sichuan earthquake the heyday of Chinese NGO activity, which demonstrated their importance to society. According to official statistics, more than 3 million volunteers and more than 260 NGOs were in the disaster area to help with medical aid and food distribution on site. At the same time, Chinese authorities began

DOI: $10.4324 / 9781003188636-10$ 
to tighten controls on NGO activities. The networking and mobilization power of NGOs and volunteers became treated as potential government control threats. In 2016, several prominent NGOs were banned, including the Women's Legal Studies Center, founded in 1995, one of the first NGOs in China (Tatlow, 2016). With the gradual withdrawal of international NGOs from China, accelerated by a 2017 law that regulates Chinese NGO activity outside of the country, most Chinese NGOs lost their source of funding. Their only option for survival was to work with the government, abide by restrictive policies, which thus weakened the Chinese civil society sector and the power of NGOs to effect social change.

Labor NGOs have emerged in China as an important feature of the country's civil society (Chan, 2012; Lee \& Shen, 2009; Ngai, 2007). However, since 2005, the Chinese government has been constantly clamping down on the activities of these organizations, limiting them to service-oriented activities and providing welfare to migrant workers as government subcontractors (He \& Huang, 2015; Smith \& Zhang, 2009; Xu, 2013). Hence, the antagonism between labor and capital has intensified, in part because labor NGOs have been unable to provide legal assistance or play a role in collective bargaining (Chan, 2016; Cheng et al., 2010; Pringle, 2011, 2013; Spires, 2011). In 2015, the crackdown entered a new phase when the Chinese government closed down a number of labor NGOs and arrested staff members who had been working to protect employees' rights and promote collective bargaining. The government's actions in this regard formed part of a broader political initiative preceded by the arrests of human rights activists, lawyers, and antidiscrimination and feminist activists (Lin, 2019).

This study examines the communication strategies employed by Inno Community Development Organisation (hereafter Inno), a labor NGO in the Guangdong province. Inno has mainly served as a subcontractor for the international brands based in Guangdong to facilitate relations between the government and migrant workers. Following the 2015 crackdown, few labor NGOs have continued to engage in rights-based work in China; however, under President Xi Jinping, the government's repressive strategies have become more sophisticated, leaving NGOs scattered, atomized, and starved of resources (Franceschini \& Nesossi, 2018). As a consequence, most labor NGOs have chosen to move away from rights-based work and transformed themselves into service-oriented and community-based organizations. It is unclear whether this strategy allows NGOs to survive and continue to help protect workers in China.

The research for this study seeks to address how a Chinese labor NGO communicates with key stakeholders to ensure its survival. Fieldwork at Inno, including in-depth interviews with team members and their migrant worker advisees, was paired with an analysis of Inno's public communication materials and website served to identify key strategies that have helped to keep Inno going despite tightening regulations: 


\section{Luwei Rose Luqiu}

1. Communication: Passive public communication strategies to legitimize the organization yet avoid arousing agitation and maintaining informal lines of communication with government officials;

2. Funding: Utilizing state-controlled resources and avoiding funding from foreign political institutions;

3. Tactics: Ensuring autonomy by using legal tactics rather than collective action tactics.

The findings also provide insights into the relationship between Inno and the migrant workers it serves, particularly relating to the notion of trust. Inno's compromises and agreements with the government have not diminished the workers' confidence in the NGO, for they have continued to express satisfaction with the services and gratitude for employer negotiations on their behalf. However, pressure to address various labor issues while working within the system has resulted in more challenging NGO-worker relationships. In addition, Chinese NGOs and news media used to work together to promote social issues and communicate for social change; however, Inno has had to cut its alliance with broadcasters and newspapers to protect itself from further government suppression.

\section{Labor NGOs in China}

China's economic reform policy has placed migrant workers in the exportdriven coastal cities, along with pensioners and the unemployed, at the forefront of labor unrest in the country. The government has looked to legal reform and the promotion of legal rights for workers; thus, the landmark National Labor Law went into effect in 1995, and three more major national labor-related laws were passed in 2007. These efforts on the part of the state have created space for labor NGOs to interact with workers, who are legally barred from organizing independent unions. Seeking to limit the autonomy and growth of labor organizations, the government has cracked down on a few select NGOs and sought to co-opt others (Lee \& Shen, 2009).

Scholars used to be optimistic about the role of labor NGOs in China. For, while these organizations have had little power in the face of the state's capacity to monitor and even criminalize their activism, they have created a space in which it has been possible to provide vulnerable migrant workers with legal advice and help them to organize (Chan, 2012). He and Huang's (2015) investigation of NGOs involved in promoting the rights of migrant laborers in the Pearl River Delta region demonstrated the multifaceted nature of state-grassroots interactions in the period from 2007 to 2012. When the government used oppressive tactics in its dealings with these grassroots organizations, they responded by emphasizing the righteousness of their cause and portraying themselves as working to realize the government's commitments to migrants so as to garner legitimacy and social recognition. At the same time, they avoided making confrontational statements 
in an effort to ensure that the government would continue to tolerate their activities. He and Huang (2015) thus showed that, despite an atmosphere of distrust, an unspoken agreement formed between the state and NGOs even as state power was increasing and social organizations that agreed to work within the boundaries drawn by the government were able to thrive.

The findings of this and similar studies suggested that, as NGOs cooperate more with the state, they become increasingly isomorphic in their structures and processes. On the other hand, a study of NGOs in India found that, while these organizations pursued strategies of cooperation with the state, each also used a distinct set of tactics in responding to the same public policy environment owing to the path-dependent factor, which helped to ensure that they maintained their organizational commitment to their founding values (Ramanath, 2009). Because labor NGOs in China must cooperate with the government in order to survive, the strategies that they use to interact with the state are of particular concern. Under these circumstances, a fundamental question arises regarding whether these organizations, because they are under the control of the state and must act in a manner consistent with the government's objectives and avoid such sensitive issues as labor rights activism, may begin to lose the trust of the workers whom they serve. As Franceschini (2014) pointed out, labor NGOs in China negotiate with various actors, including workers, the state, donors, and other labor NGOs. Of these negotiations, those with the state are the key to an organization's survival. It must identify the proper government departments with which to register and also endure frequent harassment by the authorities, such as meetings with public security officials. The organizations' negotiations on behalf of workers depend on their ability to maintain trust and credibility. Based on fieldwork, including interviews with those working for labor NGOs, Franceschini (2014) identified two factors that were undermining the credibility of the NGOs among migrant workers: distance from the state and lack of media involvement or other forms of publicity.

\section{Theory and Methodology}

Previous research demonstrated that institutionalized communication between labor NGOs and the local state can serve as a channel for NGOs to deploy their professional expertise and service experiences in the formulation of policy (Hsu \& Hasmath, 2014). Although some suggestions by these organizations have been ignored or blocked, others have been adopted by the local state and have helped to improve local governance. Such successful advocacy outcomes are attributable to the connections among NGOs, the local state, and other state organizations (Yuen, 2018). Scholars who study NGOs at the pre-civil society stage in China have argued that the informal politics in which the Chinese party-state and NGOs have been engaging cannot depend on a set of long-term, formal rules because the authority predominate the power structure. Under the circumstances of a 


\section{Luwei Rose Luqiu}

strong government, strong capital, and weak labor that prevail in the Chinese market, which functions in accordance with vague and informal rules, the interactions between state organizations and NGOs have become unbalanced, and uncertainty is inevitable in informal politics (Cheng et al., 2010). Independent NGOs are treated as potential threats to officials, and grassroots groups operate under the constant threat of suppression (Spires, 2011). Since the Chinese government increased its pressure labor movements and labor NGOs in 2015, there have been concerns not only that the defense of labor rights would lead to social instability but also that these organizations have political agendas. In any case, labor NGOs in China have undergone rapid deterioration over the past few years, with independent organizations either being forced to cease operations or, as in the case study that is the focus of this study, transformed into community service organizations.

Inno was founded in 2007 and has since been involved in several labor disputes, strike actions, and protests in southern China, playing the role of a mediator among workers, factories, and the local government. The NGO has also provided hotlines and training courses for migrant workers in need of legal advice and occupational training. Working with various international brands, Inno has monitored the conditions for employees in Chinese factories and subsidiaries. In this study, the narrative approach served as the framework for exploring Inno's tactics in dealing with, and cooperating with, the state as well as with workers.

Literature relating to organization theory has suggested that storytelling can produce a rich body of knowledge (Stutts \& Barker, 1999). From a micro-perspective, narratives have been recognized as important political tools (Rhodes \& Brown, 2005) that often serve to reproduce power relations reflexively (Boje et al., 1999). Scholars have often linked narratives to subjective notions of hegemony and legitimacy; thus, narrative approaches enable subjectivity to be understood as being (Chappell et al., 2003). Narrative approaches have also been used to study organizational change and learning, the idea being that stories help to manage changes in organizational culture (Brown et al. 2005; Meyer, 1997). Narrative approaches are also well suited to use in political games in which individuals and coalitions need to present information in specific ways to specific audiences. Narratives create and sustain organizations as fractured and hierarchical locales, acting as a form of discipline by construing the members of organizations, their actions, and their relationships in distinctive ways (Brown, 1985; Keleman \& Hassard, 2003).

The research for this study included in-depth interviews with Inno's founder, three members of its staff, and seven migrant workers whom it was advising. The interviews were conducted in 2016, 2017, and 2019, respectively, and supplemented by fieldwork in June 2017, which included office visits and participation in training courses in a factory in Shenzhen. Additionally, Inno's public communication channels, in particular Inno's official website, were analyzed to draw conclusions about their external communication 
strategies. This was supplemented by an examination of international and Chinese domestic media coverage of the NGO in order to review Inno's strategies in communicating with the news media. From January 1, 2011, to October 10, 2017, 22 articles were collected using the keyword search by WiseNews, in both Chinese and English. WiseNews provides full-text articles from over 800 key newspapers, magazines, and websites from different countries, including China, Hong Kong, Macau, Taiwan, and the United States. An inductive textual analysis served to identify themes that emerged from these documents.

\section{Findings}

\section{Negotiations with the State}

Because NGOs cannot register independently in China, when Inno was established, it registered as a commercial company, and in 2010, in order to conduct a campaign against hepatitis B discrimination in the workplace, it affiliated with a government agency. Like all NGOs in China, Inno has been dealing with various governmental departments from the moment it began operations. Li Di, the organization's founder, recalled when interviewed in Guangzhou for this study that communication with government officials took place mainly in informal settings, such as restaurants; formal meetings were held in the offices of government agencies only on the rare occasions when high-ranking officials wanted to be briefed in person about a labor issue rather than to receive information from the officials under them.

Li was first summoned by the police for an interview in 2009, and, while he was questioned carefully about the scope of Inno's activities, the main point was to send the message that the authorities would always be watching the organization and every move made by members of its staff. Despite the pleasant atmosphere, in retrospect, $\mathrm{Li}$ understood that he was being warned to remain within the bounds of the law and not to try to deceive the authorities. As a consequence, he adopted over the years a policy of full disclosure in his dealings with the authorities, for he recognized both that there was no way to hide the organization's activities and that frankness would increase the authorities' trust in him. As an example, he described reporting to government officials a 2013 interview on France 24 along with the head of another labor NGO in which he had shared his views on labor relations in China. The local government did not react, but the international brand with which he was working at the time expressed concern about reprisal because the other individual with whom he had appeared in the interview was seen as labor rights activist by the Chinese government; and, indeed, an employee of that individual's labor NGO working in Shanghai was arrested by local police shortly after the program aired.

Though Inno has been working actively to resolve labor disputes in factories, consistently from the organization's founding through to the time of this research, $\mathrm{Li}$ has avoided labeling it a labor NGO. This also becomes evident in the absence of NGO terminology on Inno's website, in other 


\section{Luwei Rose Luqiu}

public forums, and in media interviews. Instead, Inno emphasizes its role in providing community services, including serving as an independent third party assisting efforts by businesses to mitigate labor disputes. In an environment in which civil society is essentially closed, Inno has taken a "nothing" approach to solving problems within factories through the creation of workers' hotlines. Avoiding conflict with the government and remaining within the bounds set by it has been Li's second guiding principle in dealing with Chinese authorities, particularly with regard to sources of funding. As he described his strategy:

Don't take funds from sensitive institutions abroad. The government has a list, so never work with the organizations on the list or have any connection with them; it's a red line because, once it's touched, there's no room left for maneuvering. Some Chinese labor NGOs appear on the list of partner organizations on the websites of these sensitive organizations, and there's really no excuse for that at all.

Although the Guangdong government finally introduced a set of Regulations on Collective Contracts in Enterprises in September 2014, the law was so watered down that it was ineffective. In 2014, as labor organizations began to lose their viability and become even more constrained, the door was closed on involvement in issues in which they would formerly have been able to intervene and that some local officials had also been interested in exploring, such as workers' attempts to secure collective bargaining rights (Brown, 2015). The Law on the Administration of the Activities of Foreign NGOs in China that went into effect at the beginning of 2017 stipulates that foreign NGOs, including charitable and environmental groups, must register with the Public Security Department before establishing an office in the country and empowers the police to investigate these organizations and to blacklist those deemed to have challenged the state (by such acts as promoting secession) so that they are unable to expand their operations. The effect of the law has been to restrict foreign projects and thereby to disrupt the funding chain for labor NGOs in China (Feng, 2017). Thus, Li viewed 2017 as

a turning point, and everyone can feel the authorities becoming increasingly wary of all organizations with ties outside [China's] borders. We had projects in many factories in Nanhai City at that time to help workers, and, as a result, I heard rumors that we were planning to join with a labor NGO in Hong Kong to agitate the workers to cause trouble. This is, of course, a rumor; I have zero connection with that NGO, which has been labeled as "foreign force." But I have no way to go straight to the local government to clear up a rumor. I don't know who is spreading this rumor, and, as far as I am concerned, I smell danger, so I feel the safest thing to do is to leave immediately and end all projects. 
The last labor rights case in which Inno was involved concerned the death of a child laborer in a factory in Guangdong in 2016. The organization submitted an investigative report on the supplier, brand, and factory monitoring agency with the conclusion that the direct responsibility for the child's death lay with the brand and monitoring agency but that the central government should be taking more vigorous steps to end child labor. In the end, however, neither the brand nor the monitoring agency, nor the central government responded to the report, and the issue of child labor in China remains unresolved. In this and earlier such reports by Inno, the terms "human rights" and "labor rights" appear frequently. As of 2017, however, Inno ceased its involvement in actions related to labor disputes to focus instead on projects including the anti-Hepatitis B discrimination initiative mentioned earlier, helping the children of migrant workers left behind in rural areas when their parents seek work in the cities and training women migrant workers. Further, articles about labor disputes have been removed from Inno's official website and replaced with articles about educational programs for workers implemented in cooperation with local governments.

In 2019, Inno began focusing on projects in Sri Lanka, helping international brands to oversee local factories and handle labor disputes there. This initiative is an example of Li's third strategy in dealing with the government, which has been to prove that Inno's raison d'être is consistent with the Chinese government's vision for NGOs. The success of this strategy is suggested by the fact that Inno is currently the only voting member representing the World Hepatitis Alliance's China Region as well as a member of that group's Western Pacific Regional Executive Committee, in which capacity he has been telling the Chinese story to the international community and in particular highlighting advocacy efforts in Chinese civil society and progress in controlling the disease in the country. Li's access to such international platforms has given him a position analogous to that of a "foreign propagandist" in the eyes of the government and thereby made him appear more independent and persuasive than official government spokespersons when it comes to burnishing China's image abroad. When it comes to domestic issues, Li has done his best to convince the government that his aims are to solve labor problems and prevent the strikes, demonstrations, and assemblies that the government, concerned as always with social stability, considers so problematic. Li reflected during the interview on Inno's earlier activism:

In 2014, what was arguably the largest strike ever occurred in Guangdong, with 40,000 to 50,000 workers taking to the streets. We intervened before the workers took to the streets after one of them broke the news to us through our hotline. We have also been in touch with more than a hundred workers' representatives through QQ [the popular messaging service run by the Chinese Internet conglomerate Tencent] since then, and behind each one of them are 30 or 40 workers. We communicate with workers and employers while also sharing with the 


\section{Luwei Rose Luqiu}

government the information we get. I don't think we're harming the interests of the workers by doing that, and in fact the workers' representatives appreciate our efforts to try to play messenger because we'd love to pull the government in on this labor dispute. It's just a pity that the government saw this as an insoluble conflict and so eventually used armed police to end the strike.

\section{Negotiations With the Workers}

When dealing with labor disputes, many labor NGOs find it difficult to gain the trust of workers. Previous studies have identified numerous reasons for this difficulty, including organizations' alienation from the government, which leads workers to believe that organizations generally are ineffective in solving problems (Franceschini, 2014). Nevertheless, the lack of any other channel for employees to communicate with their employers and the government has fostered the emergence of labor NGOs. The situation has remained dynamic, with the relationship between these organizations and workers evolving considerably over the past three decades, from asymmetrical dependence of Chinese labor NGOs on foreign NGOs toward partnerships between them. By 2016, some workers' groups had begun to realize that their interests were diverging from those of the labor NGOs, a divergence that is explicable in terms of the general rule that, under authoritarianism, all parties adopt complex strategies to defend their own interests (Chan, 2018).

Face-to-face interactions remain the most effective means of communicating with workers, as Inno demonstrated when it was one of the first organizations to send representatives to the scene of the 2014 Guangzhou University City sanitation workers' strike. They listened to the workers' demands and distributed flyers encouraging more workers to contact them through a hotline. The matter was resolved after Inno and other organizations convinced the local government to intervene and bring the two sides to the table for a series of collective bargaining sessions. A key aspect of gaining workers' trust in such situations has been for NGOs to recognize the workers as the leaders and organizers, rather than treating them as passive followers, and to trust that they clearly understand their rights, as was reflected in Inno's report on the 2014 incident in Guangzhou:

Auntie Wang, an organizer of the University City sanitation workers' strike, said, "If we can negotiate a solution, we don't want to make a big deal out of it." That's what most workers are saying. The strike stalemate was exhausting for most workers and deprived them of their only source of income; for businesses, it was exhausting and costly in real terms. In Inno's 11 years of experience focusing on workplace grievance mechanisms, $96 \%$ of workers who identified a problem first turned to internal communication channels to resolve it. It's only when internal 
corporate communication fails that workers turn to external channels (third-party communication mechanisms, government, etc.) for help, or even the ultimate response, such as strikes or resignations. ${ }^{1}$

Communication with workers also needs to take into account intergenerational changes in China. As members of Inno pointed out in interviews, based on their observations and firsthand experiences over a decade of fieldwork, it seemed that workers were placing greater emphasis on individualism. At the same time, they have been disenchanted with their characterization as members of the proletariat, reluctant to become involved in politics, and more interested in finding new employment opportunities compared with the clientele of labor NGOs in China at the beginning of the century.

This impression is consistent with observations during my fieldwork of parents' education courses for migrant workers with children left behind in rural China, which taught parents-child communication skills. The classes met weekly in a factory in Shenzhen, and a WeChat group was set up for workers to share their parenting experiences and ask questions. After a few months of observation, it was clear that these parents were not interested in such organized activities or the establishment of a community; instead, at least some of them saw the program as merely a platform for selling products. Their proficiency in the use of various technologies has provided these workers with opportunities to earn money outside the factory, including through network sales and live streaming, both of which are popular among Chinese netizens. As a result, the gap between the lifestyles of rural migrant workers and those of their urban peers has gradually closed, with workers perceiving the role and status of labor NGOs in essentially pragmatic terms, that is, as being relevant only when there is some specific need for them. In the past, workers' activity centers, reading clubs, and other community institutions established by labor NGOs, as well as hometown associations formed spontaneously by workers, served to connect workers, but the current trend is toward atomization and discontinuous communication. To quote $\mathrm{Li}$ again,

The workers are very realistic; they are concerned with economic issues, not class issues of worker status. Although, for the international community, the workers' movement would be very attractive if it took on the nature of a proletarian labor movement, the majority of workers are not interested. They are concerned only with how to solve their problems without having to resort to collective action, which makes us need to think hard about what role to assume when communicating with workers.

\section{Negotiations with Media}

Research suggests that NGOs seek out news media for coverage as publicity strategies. NGOs play a growing role in the news coverage (Moon, 2018; Powers, 2015). The study finds that NGOs' focuses heavily depend on the 


\section{Luwei Rose Luqiu}

coverage in the mainstream news media. From the perspective of NGOs, they believe that donors use the publicity on mainstream news media as a major information source about the NGOs and an indicator to measure the impact of NGOs; government officials and politicians value media coverage because it helps them understand advocacy needs; and NGOs usually treat news media as an ally for advocacy certain issues (Powers, 2016). The communication strategy of NGOs and the media, to get more media coverage, usually focuses on celebrities, conflicts, and spectacles to fit the news value and other values prioritized by journalists (Dale, 1996; Grayson, 2014).

In China, NGOs of different nature use different media strategies. For international advocacy NGOs, they rely heavily on media coverage. For example, their project design usually contains how to get more media coverage, while local grassroots NGOs in China naturally receive media attention, one reason being that their founders often have close ties to the media or the media themselves are interested in the issues they promote. NGOs with government backgrounds, on the other hand, rely on administrative power to mobilize the media. For NGOs in China, media coverage can shape and express public opinion while legitimizing the issue and laying the groundwork for expanding the issue's political opportunities (Zeng, 2009; Zeng et al., 2019).

The founders of Inno have maintained good relations with journalists and editors of the local news media in Guangzhou. They have been able to build alliances to promote initiatives such as improving workers' working conditions and protecting their welfare. But this alliance relies on the policy environment. When the government crackdown on labor NGOs increased, it meant that the media could no longer cover these organizations. While not blacklisted, as some labor NGOs are, there is a need to find new and insensitive angles on how to get themselves covered by the media. To quote Li:

We need to portray our projects as to how we can help the government share its responsibilities and how we can help the government better maintain social stability to project a positive image of ourselves. For the news media, this is the only way journalists and editors can start with such an angle without being censored.

However, as labor NGOs have less room to survive, it has become a way to protect themselves by not being exposed in the news media and keeping a low profile. In fact, because they do not need to obtain donations and cannot promote public participation issues, they take on the government's work as subcontractors, play a service role, and no longer need to increase political resources through press coverage.

\section{Discussion}

Many studies of Chinese labor NGOs have reported that these organizations, in order to maintain their legitimacy and survive in China, have had 
to abandon labor rights advocacy and focus instead on community service (Cheng et al., 2010; He \& Huang, 2015; He et al., 2009; Spries, 2011). Inno anticipated this trend, having presented itself as a community service provider from its inception out of concern that a declared agenda of labor rights advocacy would inevitably create tension with the government. In terms of funding, because foreign agencies can no longer contribute to NGOs operating in China, it has proved effective for organizations such as Inno to present themselves as independent, third-party representatives of international brands; such an identity allows their agents to access factories in a supervisory role that may include handling labor disputes. Thus, Inno, working on behalf of various international brands, set up hotlines for workers in some 700 factories and handled some 15,000 labor disputes in the ten years from its founding to 2017 by creating dialogue mechanisms through which the workers, factories, and international brands could communicate, based on Inno's internal statistics. In addition, Inno intervened in several major labor actions in Guangdong, including the aforementioned 2014 sanitation workers' strike. Like other labor NGOs, Inno took these steps both owing to a sense of social responsibility and in the hope that the workers could leverage the organization's accumulated experience resolving disputes through communication. The Chinese government has tended to regard with suspicion organizations that intervene in strikes (Gray \& Jang, 2015). Unlike some labor NGOs, therefore, Inno has emphasized its role, not in organizing strikes, but as a trustworthy and impartial messenger reminding governments of their responsibility to reconcile labor and management. Quoting Li one last time:

Looking at our labor hotline database, we can't help but ask again: is a work stoppage really the best way to defend workers' rights? After all, the Chinese people, who value peace, have always abhorred conflict unless it cannot be avoided. Based on China's experience, system, and culture, professional neutral mediation can help employers and employees break through communication barriers and find shared values more quickly, provided that there is a professional, independent third party to facilitate the communication.

Even with such caution, Inno's room to maneuver, like that of other labor NGOs, narrowed after 2012. Inno and other such organizations not seen by the authorities as antagonistic managed to remain active in the factories and engaged with workers by providing vocational training programs for a while. However, despite such cooperation with the government and self-restraint, even this level of involvement in labor disputes became completely impossible after the new legal regime was enacted in 2017. In order to survive, organizations such as Inno had to abandon community advocacy entirely, further narrowing the scope of their activities. It was in this context that they began turning their attention to development projects elsewhere in 
Southeast Asia (such as Inno's project in Sri Lanka), building on their past experience of cooperation with various international brands. Yet even when operating outside the country, these organizations have remained under the tight control of the Chinese government, which through harassment and threats has continued to drive away their employees. Thus, Inno's founder has considered shuttering the organization to escape the fear and frustration caused by the ongoing uncertainty about how its relationship with the government will evolve in the future.

Workers' needs and attitudes toward NGOs are also changing. Thus, a study of female migrant workers showed that their desire for physical consumption was influenced by both urban consumer culture and the image discipline of migrant workers on the part of their employers, a situation that led to psychological conflicts and tensions between employees' desired status and their actual status and caused them to create dual identities (Xia, 2011). This study showed that younger migrant workers, being well-educated and closely connected to the broader society through the Internet, differed from earlier generations in no longer identifying themselves as workers, being even less sensitive to the notion of class, and lacking motivation to participate in mass protests or assemblies. The younger generation has shown a preference for an independent and individualized living environment, so that the hometown, which once played an important role in connecting workers, has diminished greatly in importance or even been completely ignored. It is only when their livelihood or prerogatives have been threatened that these workers have shown any desire to act collectively. They have been unwilling to allow the labor NGOs to become involved in their workplaces because many of these organizations have been unable to meet workers' expectations with regard to providing legal and other support. The government's suppression of labor NGOs over the years and accusations that they have colluded with foreign powers have also eroded younger workers' trust in these organizations, because this generation tends to be more patriotic and to trust the government more than the generation that preceded it. For labor NGOs, the fundamental challenges today include dealing with the generational renewal of the community of workers, keeping up with this change, and gaining workers' trust.

\section{Conclusions}

In 2019, Chinese authorities expanded their crackdown on labor organizers, arresting at least five across the country on charges frequently used to target human rights lawyers and activists in China, such as "disturbing the public order" (Elmer, 2019). Paradoxically, the governing Chinese Communist Party proposed to include NGOs, within the framework of the government as a means to promote social stability and to demonstrate an interest in civil society ("Communiqué of the Third Plenary Session," 2013). In such an environment, the scope for NGOs' activities has been suppressed actively 
and defined by the government. Constant pressure, coupled with cutting access to foreign funding sources, has forced NGOs in China to forge relationships with that same government, which provides funding in exchange for information on their activities (Wei, 2017).

Through fieldwork, including interviews, observations, and textual analysis, this study provides insights from Inno, a labor NGO, which has thus far been able to avoid government shutdown. Inno's strategies include passive communication practices with the government; using state-controlled resources and avoiding funding from foreign political institutions; and ensuring autonomy whenever possible by using legal tactics instead of protest-based campaigns. Inno has also had to create carefully crafted public communication narratives to shape their opinion and resorted to cutting alliances with news organization to ensure their survival. Despite these efforts, Inno's relationship with worker clients has become increasingly strained amid government crackdowns.

Since 2017, Inno has managed to keep a low profile and has not appeared in the news media. In 2018, Inno shifted to providing only educational services for workers-the NGO is no longer involved in worker empowerment or legal rights protection. In 2020, Inno's services focused on providing health guidelines for COVID-19 prevention in the workplace by providing a 24-hour hotline and advocating for gender equality. Inno continues to act in the role of a local labor representative for international brands with operations in China. These strategies are part of Inno's a goodwill gesture toward the government, allowing the NGO to position itself between brands, factories, workers, and the government, ultimately ensuring their survival of the Chinese government's crackdown on labor organizations.

Further, in the wake of the Umbrella Movement in Hong Kong and the Sunflower Movement in Taiwan, the government's justification to oversee NGO activity has shifted from maintaining social stability to confronting threats to national security. Thus, there has been the legislation of banning foreign funding of NGOs, the disbanding of "disobedient" NGOs, the purchasing of NGO services by government agencies, and the establishment of government branches within some NGOs (Zhao, 2015). Having watched these continuous changes in NGO policy for over a decade after the founding of Inno, $\mathrm{Li}$ has been made well aware that, at least in the foreseeable future, NGOs in China will simply be unable to engage in advocacy for labor rights. Those that continue to operate have no choice but to work in support of the government's efforts to maintain social stability and curb threat.

Because the Chinese authorities prohibited news about labor strikes and protests, labor NGOs serving workers have no access to relevant information. This has effectively cut off the public communication channel between workers and their organizations. The forced, cooperative relationship between labor organizations and the government has also created deep distrust among workers, who have given up the initiative to seek help from third parties, 


\section{Luwei Rose Luqiu}

such as NGOs. As for Chinese workers today, their growing ability to solve problems autonomously deserves recognition. As the government moves to completely stifle the possibility of independent labor unions and labor NGO campaigning, it must prepare itself to deal with an unpredictable array of unorganized and radical labor actions without the assistance of a trustworthy go-between.

From environmental NGOs to labor NGOs and gender equity NGOs, any Chinese NGO hoping to mobilize for collective action must cooperate with the government, become part of the government's stabilization machine, and participate in their social governance program. However, the definition, functions, and roles of NGOs have been gradually changed by the Chinese government to serve the state with social conflicts. The question of what impact NGO policy will have on social justice efforts vis-à-vis regime stability will remain to be seen.

\section{Note}

1. Inno Community Development Organisation, 2018.

\section{References}

Boje, D. M., Luhman, J. T., \& Baack, D. E. (1999). Stories and encounters between storytelling organizations. Journal of Management Inquiry, 8(4), 340-360.

Brown, M. H. (1985). That reminds me of a story: Speech action in organizational socialization. Western Journal of Communication [including Communication Reports], 49(1), 27-42.

Brown, R. C. (2015). Collective bargaining in China: Guangdong regulation a harbinger of national model? China-EU Law Journal, 4(2-4), 135-154.

Brown, A. D., Humphreys, M., \& Gurney, P. M. (2005). Narrative, identity and change: A case study of Laskarina Holidays. Journal of Organizational Change Management, 18(4), 312-326.

Chan, A. (2016). China's workers under assault: Exploitation and abuse in a globalizing economy. London, England: Routledge.

Chan, A. (2018). The relationship between labour NGOs and Chinese workers in an authoritarian regime. Global Labour Journal, 9(1), 1-18.

Chan, C. K. C. (2012). Community-based organizations for migrant workers' rights: The emergence of labour NGOs in China. Community Development Journal, 48(1), 6-22.

Chappell, C., Rhodes, C., Solomon, N., Tennant, M., \& Yates, L. (2003). Reconstructing the lifelong learner: Pedagogy and identity in individual, organisational and social change. London, England: Routledge.

Cheng, J. Y., Ngok, K., \& Zhuang, W. (2010). The survival and development space for China's labor NGOs: Informal politics and its uncertainty. Asian Survey, 50(6), 1082-1106.

Communique of the Third Plenary Session of the 18th Central Committee of the Communist Party of China. (2013). BBC. Retrieved from https://www.bbc.com/ zhongwen/trad/china/2013/11/131112_183rdannualplenum 
Dale, S (1996). McLuhan's Children: The Greenpeace Message and the Media. Toronto: Between the Lines.

Elmer, K. (2019). At least five labor rights activists arrested across China. South China Morning Post. Retrieved from https://www.scmp.com/news/china/politics/ article/2183209/least-five-labour-rights-activists-arrested-across-china

Feng, C. (2017). The NGO law in China and its impact on overseas-funded NGOs. Cosmopolitan Civil Societies: An Interdisciplinary Journal, 9(3), 95.

Franceschini, I. (2014). Labour NGOs in China: A real force for political change? The China Quarterly, 218, 474-492.

Franceschini, I., \& Nesossi, E. (2018). State repression of Chinese labor NGOs: A chilling effect? The China Journal, 80(1), 111-129.

Gray, K., \& Jang, Y. (2015). Labour unrest in the global political economy: The case of China's 2010 strike wave. New Political Economy, 20(4), 594-613.

Grayson, L (2014) The role of non-government organisations (NGOs) in practising editorial photography in a globalised media environment. Journalism Practice, $8(5), 632-645$.

He, A. J., \& Huang, G. (2015). Fighting for migrant labor rights in the world's factory: Legitimacy, resource constraints and strategies of grassroots migrant labor NGOs in South China. Journal of Contemporary China, 24(93), 471-492.

He, J. Huang, P. \& Huang, H. (2009). Sandwiched between resources and institutions: Survival strategies of rural migrant workers' grassroots NGOs. Society, 29(6), 1-21.

Hsu, J. Y., \& Hasmath, R. (2014). The local corporatist state and NGO relations in China. Journal of Contemporary China, 23(87), 516-534.

Inno Community Development Organisation (2018). 144 hours of bargaining and compromise. Inno. Retrieved from https://www.theinno.org/blog/144

Kelemen, M., \& Hassard, J. (2003). Paradigm plurality: Exploring past, present, and future trends. In R. Westwood \& S. Clegg (Eds.), Debating organization: Pointcounterpoint in organization studies (pp. 73-82). Oxford, England: Blackwell.

Lee, C. K., \& Shen, Y. (2009). China: The paradox and possibility of a public sociology of labor. Work and Occupations, 36(2), 110-125.

Lin, K. (2019). China's labor reforms dwindle after government crackdown. East Asia Forum. Retrieved from https://international.thenewslens.com/article/124338

Liu, Q., \& Wang, M. (2009). An Analysis of the Development of China's NGOs and Its Social Foundation since the Reform and Opening Up [J]. Journal of Public Administration, 3.

Meyer, J. C. (1997). Humor in member narratives: Uniting and dividing at work. Western Journal of Communication [includes Communication Reports], 61(2), 188-208.

Moon, R. (2018). Getting into living rooms: NGO media relations work as strategic practice. Journalism, 19(7), 1011-1026.

Ngai, P. (2007). Gendering the dormitory labor system: Production, reproduction, and migrant labor in south China. Feminist Economics, 13(3-4), 239-258.

Powers, M (2015) Contemporary NGO-journalist relations: Reviewing and evaluating an emergent area of research. Sociology Compass, 9(6), 427-437.

Powers, M. (2016). NGO publicity and reinforcing path dependencies: Explaining the persistence of media-centered publicity strategies. The International Journal of Press/Politics, 21(4), 490-507. 


\section{Luwei Rose Luqiu}

Pringle, T. (2011). Trade unions in China: The challenge of labour unrest. London, England: Routledge.

Pringle, T. (2013). Reflections on labor in China: From a moment to a movement. South Atlantic Quarterly, 112(1), 191-202.

Ramanath, R. (2009). Limits to institutional isomorphism: Examining internal processes in NGO-government interactions. Nonprofit and Voluntary Sector Quarterly, 38(1), 51-76.

Rhodes, C., \& Brown, A. D. (2005). Narrative, organizations and research. International Journal of Management Reviews, 7(3), 167-188.

Smith, M., \& Zhang, H. (2009). Navigating a space for labor activism: Labor NGOs in the Pearl River Delta of South China. In J. Schwartz \& S. Shieh (Eds.), State and society responses to social welfare needs in China (pp. 82-104). London, England: Routledge.

Spires, A. J. (2011). Contingent symbiosis and civil society in an authoritarian state: Understanding the survival of China's grassroots NGOs. American Journal of Sociology, 117(1), 1-45.

Stutts, N. B., \& Barker, R. T. (1999). The use of narrative paradigm theory in assessing audience value conflict in image advertising. Management Communication Quarterly, 13(2), 209-244.

Tatlow, D. K. (2016). China is said to force closing of Women's Legal Aid Center. The New York Times. Retrieved from https://www.nytimes.com/2016/01/30/world/ asia/beijing-women-legal-aid-guo-jianmei.html

Wang, M. (2001). The development of NGOs in China. The Nonprofit Review, 1(1), 53-63.

Wang, M., \& Liu, Q. (2009). Analyzing China's NGO development system. The China Nonprofit Review, 1(1), 5-35.

Wei, X. (2017). An analysis of the governance pathway of China's government-NGO cooperation for stability during the transition. Law and Society, 11, 119-139.

Xia, W. N. Y. (2011). "Double-Way" of Consumption and Double Identities: A Qualitative Study of the Physical Consumption of Female Migrant Workers in Service Sector in the J Industrial Zone in Guangzhou [J]. Jiangsu Social Sciences, 4.

$\mathrm{Xu}$, Y. (2013). Labor non-governmental organizations in China: Mobilizing rural migrant workers. Journal of Industrial Relations, 55(2), 243-259.

Yuen, S. (2018). Negotiating service activism in China: The impact of NGOs' institutional embeddedness in the local state. Journal of Contemporary China, 27(111), 406-422.

Zeng, F. X. (2009). NGO's media agenda building under state control: The case of China. Communication \& Society, 8, 19-53.

Zeng, F., Dai, J., \& Javed, J. (2019). Frame alignment and environmental advocacy: the influence of NGO strategies on policy outcomes in China. Environmental Politics, 28(4), 747-770.

Zhao, S. (2015). The nest: The life and death of NGOs in China. The Initium. Retrieved from https://theinitium.com/article/20150917-mainland-NGO3/ 


\title{
8 Organizational Legitimacy and Communication on Social Networking Sites
}

\author{
A Case Study of Sadagaat and the \\ Hawadith Street Initiative in Sudan
}

\section{Maha Bashri}

\section{Non-Governmental Organizations and the Age of Social Networking Sites}

Non-governmental organizations (NGOs) are actors that are usually outside the market and the state (Diamond, 1994; Brysk, 2000). They have the ability to build social capital, create communities with different societal stakeholders, and in many instances fill a void left by the state (Foley \& Edwards,1996). In countries under authoritarian regimes or transitioning governance, the role of NGOs is even more significant with respect to community-building, information sharing, and shaping public consciousness (Keck \& Sikkink, 2014). In order for NGOs to fulfill these roles, they must maintain high levels of accountability and transparency in their communication and transactions (Della Porta \& Mattoni, 2015).

The participatory and interactive nature of social networking sites (SNSs) has enabled NGOs worldwide to engage in new ways of advocacy and mobilization (Campbell, Lambright \& Wells, 2014). The Internet has facilitated the work of NGOs because they are now able to reach and mobilize audiences both online and offline (Gleason, 2013). The transparency of communication by these NGOs on SNSs is a determining factor of how successful they are in fulfilling their missions. They are moral actors who are expected to take full responsibility for their actions and communication; actions which commit or omit (Geser, 1992). Organizations anchor their actions based on their missions, values, and cultural contexts (Weber, 1978).

Sudanese NGOs have benefitted from the integration of SNS. Platforms such as Facebook and Twitter have provided communicative spaces that circumvent government censorship. Furthermore, they have allowed for a wider diffusion and reach of messaging by NGOs. The Internet in Sudan has played a crucial role in allowing those who historically had no voice and participation in discourses on gender, politics, and peace matters to be heard (Bilal, 2005; Ibrahim, 2001; Nageeb, 2006).

Sudan has a population of 43 million people and approximately $31 \%$ have access to the Internet (Datareportal, 2020). The figures are considerably low

DOI: $10.4324 / 9781003188636-11$ 
when compared to global standards, but they have had a significant impact on how information is disseminated in Sudan. The Internet and SNSs have given rise to a "parallel market of information" where NGOs, activists, and citizen journalists have been able to reach wider audiences (Bashri, 2014; Lamoureaux \& Sureau, 2019). SNSs have been especially important for NGOs in Sudan because they have provided an inexpensive and effective information dissemination conduit. Early on, Sudanese NGOs successfully leveraged the opportunities provided by SNSs-organizers and advocacy groups target young Sudanese netizens who are active on social media. This key audience is important for Sudanese NGOs to mobilize adherents and fulfill their social change missions.

Studies on NGOs and their use of new media to communicate with stakeholders have mostly examined Western contexts (see, for example, Campbell, Lambright \& Wells 2014; Cho, Schweickart \& Hasse 2014; Etter, Ravasi \& Colleoni 2019; Saxton \& Waters 2014).

While these studies have shed light on NGOs, their organizational structures, as well as their ability to influence change, they do not necessarily speak to contexts similar to Sudan's where the government censors both communication and Internet access. Furthermore, from an organizational legitimacy perspective, transparent and credible information is the first step in negotiating organization legitimacy (Svensson, Mahoney \& Hambrick 2014; Zhou \& Pan, 2016). Credible and transparent information, especially in civic, political, and economic discourses, tends to be lacking in contexts such as Sudan's.

The following case study focuses on the successful use of SNSs by two Sudanese NGOs_-"Sadagaat" [charity] and the "Hawadith Street Initiative"which are two of the largest in the country (Ahmed \& A-Rahman, 2015; Salih \& Swar, 2015). SNSs have been key in their campaigns and facilitated the dissemination of information as well as mobilized online and offline networks to provide economic, educational, and health care assistance to the citizenry. The analysis adopts the "Information-Community-Action" framework developed by Lovejoy and Saxton (2012). This framework categorizes posts on SNSs based on their function for NGOs. The analysis examines the communication patterns utilized by these two NGOs on Facebook to better understand how they were able to mobilize their networks and fulfill their missions while maintaining high levels of transparency and accountability. Facebook was selected to examine the NGOs' communication patterns because it is the most used SNS by both individuals and organizations in Sudan (Datareportal, 2020).

\section{Sadagaat and the Hawadith Street Initiative: Social Change NGOs in Sudan}

Sadagaat started as a volunteer-run initiative in 2002 and formally registered as an NGO in 2012 (Knowledge @Wharton, 2013). It was conceived 
by members of the Sudanese diaspora in the United States. The organization's main mission focused on providing social services across Sudan, filling the gap left by the state. Its efforts expanded to include partnerships with private enterprises within and outside the country as well as the Sudanese diaspora. The group partnered with private for-profit organizations to solve and financially support social issues while utilizing a non-governmental approach; a novel idea in Sudan that has been received positively by stakeholders.

South Sudan's secession in 2011 placed a huge strain on Sudan's already fragile economy and political stability. Economic growth stagnated greatly, while disenfranchised areas throughout the country suffered even more. Consequently, Sadagaat recalibrated its mission to focus on setting up developmental projects across the country in an attempt to ease some of the economic strain. The projects were planned and executed based on scientific data and feasibility studies. Sadagaat expanded its initiatives into the medical, educational, and social service sectors. It established schools and hospitals in regions of the country that were not being serviced. Water and electricity stations running on solar power were designed by Sudanese engineers and put up to work in villages in the war-torn region of Darfur in western Sudan (Al Saadawy, 2013).

Sadagaat has an active Facebook page where it engages regularly with its 40,000 followers. Since its inception, the NGO has understood the important role of strategic and transparent communication to fulfill their organizational missions (Suchman, 1995). Transparent communication is the means by which organizations can inform, rally, and mobilize their stakeholders into action. Accordingly, Sadagaat's mission stresses transparency and open communication with stakeholders. Since the NGO's formal registration in 2012, Sadagaar publishes its annual reports on Facebook, which includes detailed information on how money is collected, and how funds are allocated to projects. This is also communicated to stakeholders. Anwar Ibrahim Yagoub, Sadagaat's head, stressed in an interview the importance of transparency in the NGOs communication with stakeholders (e.g., volunteers and donors) (Knowledge@Wharton, 2013). He emphasized the importance of transparency in communication as an organizational approach that helps NGOs to fulfill their missions and creates what is called a circle of trust in the nonprofit sector. This transparency in communication is even more important in environments such as Sudan's where trust in government institutions and organizations has been greatly eroded. Sadagaat's open communication has paid off generously in terms of an increase in the number of volunteers and donors.

Shari' Al Hawadith, or what has been translated into Hawadith Street Initiative, is a smaller Sudanese NGO that was founded in 2012. HSI was first conceived as a crowdfunding initiative to cover treatment costs in the capital, Khartoum, for a young child from the impoverished western region of Kordofan. The group is mainly composed of young university graduates 
(Ahmed \& A-Rahman, 2015). Since its inception, HSI adopted Sadagaat's transparency approach on communication, aiming to build a long-lasting relationship based on trust with its stakeholders. Both organizations attribute their use of Facebook as the primary channel of official communication with stakeholders because of ease of dissemination and little to no setup costs (Othman, 2015).

HSI's activities evolved to focus on medical services. For example, the group created recreational programs for patients in the cancer ward in Khartoum Hospital. HSI also spearheaded several successful blood drive initiatives across different parts of the country; a challenging feat in a country lacking proper medical resources to store blood. The group grew from 15 volunteers in 2012 to 2000 volunteers in 2015. However, it was never formally registered as an NGO because Al-Beshir's regime did not allow it to (Salih \& Swar, 2015). In 2013, HSI established a pediatric intensive care unit in one of the largest government hospitals. The unit cost $\$ 435,880$ (Salih \& Swar, 2015), a formidable achievement for a voluntary grassroots group.

HSI's projects are funded by citizens in Sudan and the Sudanese diaspora. The group has succeeded in bringing together Sudanese to fund and establish much needed medical projects and care for citizens. Its initiatives are unique because it is one of the first groups in Sudan to utilize social media to communicate and mobilize stakeholders. HSI's communication model on social media became a framework for several grassroots groups conceived after it (Ahmed \& A-Rahman, 2015). HSI has 118,595 followers on Facebook; while it is a smaller group in terms of its funding and followers than Sadagaat, it has a great impact on providing medical services in all parts of Sudan. This impact and ability to mobilize stakeholders led the former Al-Bashir regime to target the group and its initiatives on more than one occasion (Elbagir, 2016).

\section{Information-Community-Action Framework: An Opportunity for NGOs on Social Network Sites}

New media and Web 2.0 technologies have enabled NGOs to share, engage, and create social capital with their stakeholders efficiently, rapidly, and in inexpensive ways. These new communication technologies have heightened need for transparency and accountability on the organization's side (Nah \& Saxton 2013; Rosen, 2010; Saxton, Guo \& Brown, 2007). Moreover, stakeholder engagement and symmetric communication became critical factors for NGOs to fulfill their missions (Kent, Taylor \& White, 2003).

SNSs such as Facebook, YouTube, Twitter, Instagram, etc., have provided easy-to-use platforms that not only disseminate information but also engage audiences (Guo \& Saxton 2014; Lovejoy, Waters \& Saxton 2012; Waters \& Jamal, 2011). NGOs find that SNSs facilitate reaching out to their stakeholders and educating those who fall into the aware category 
(Weberling, Waters \& Tindal 2012). Kelleher (2009) notes that on such platforms, organizations demonstrating open communication in a conversational manner with their stakeholders build trust and a sense of community. This strategic dimension of SNSs is an important factor in mobilizing stakeholders on the ground (Breakenridge, 2012).

Scholars have argued that NGOs tend to align their adoption and usage of SNSs to their organizational strategies (e.g., service-focused, donorfocused, lobbying); governance features (e.g., membership structure, organizational hierarchy); capacities (e.g., size, number of trained staff who can maintain their website, current presence on the web); and external pressures (funding sources and donors) (Nah \& Saxton, 2013; Zhou \& Pan, 2016). Other scholars posit that SNS adoption by NGOs is guided by factors deeper than organization strategies. Adoption of these platforms aids these organizations in the creation and maintenance of two-way symmetric communication and a participatory culture with stakeholders (Macnamara, 2010). Two-way symmetric communication creates a huge challenge for organizations, primarily because they will no longer be the sole controllers over content on their platforms. Followers will now have the ability to post without deferring to organizational controls. Several studies have shown that despite the high levels of engagement with organizational messages created by a two-way symmetric model of communication, nonprofits in the United States avoid it because it might mean the loss over control of messaging (Bortree \& Seltzer 2009; Cho, Schweickart \& Hasse, 2014; Quinton \& Fennemore, 2013).

Lovejoy and Saxton (2012) analyzed how nonprofits (NGOs) in the United States used Twitter to communicate. Their study examined how social networking platforms (in this case Twitter) are utilized by nonprofits and what (if any) role they play in helping them to achieve their missions and goals. Based on their findings, the authors proposed a three-step hierarchical framework: Information-Community-Action. Lovejoy and Saxton posit that SNSs should have two main organizational functions: dissemination of information and dialogue between stakeholders. Dialogue is defined by Kent and Taylor (1998) as "any negotiated exchange of ideas and opinions" (p. 325) and is considered a key factor that determines trust on the part of stakeholders enabling NGOs to fulfill their missions.

Organizations utilize social networking platforms to post information for the sake of informing stakeholders and gaining followers; they then build a community of followers through dialogue and symmetric communication; finally, they rally and mobilize this mass of followers to achieve their set objectives. Their findings reveal, that for the most part, the organizations they studied were using Twitter primarily as a one-way channel of communication to inform stakeholders while neglecting its potential in creating social capital through dialogue with them. These findings are similar to other studies examining small community human service organizations and environmental advocacy groups in the United States, where such organizations used SNSs primarily 
to publicize their activities rather than to maintain dialogue with stakeholders (Bortree \& Seltzer, 2009; Svensson, Mahoney \& Hambrick, 2014).

\section{Method}

This case study examines the communication patterns utilized by Sadagaat and HSI on Facebook. The general categories of Lovejoy and Saxton' (2012) Information-Community-Action framework guided the content analysis. This particular framework was selected because it helps in understanding how organizations disclose information, engage stakeholders, and mobilize resources (Guo \&Saxton, 2014; Lovejoy\& Saxton, 2012).

The two research questions that guide the inquiry are as follows:

RQ1: How will Sadagaat and HSI's online communication patterns on Facebook compare to those of Western NGOs on SNSs?

RQ2: How does Sudan's political context influence Sadagaat and HSI's communication on Facebook?

The case study aims to better understand how two Sudanese NGOs used SNSs to engage their stakeholders and adherents during a period of time when Sudan was under an authoritarian regime.

Using the tool Netvizz, 570 posts from the Facebook pages of the two NGOs were collected to analyze the communication patterns (341 from Sadagaat; 229 from HSI). A one-year sampling period (May 19, 2018-May 19,2019 ) was selected to examine routine communication patterns by both NGOs. Netvizz gathers data from Facebook's programming interfaces on public pages (Rieder, 2013), which includes posts, comments and replies, time stamps, and likes and shares. To ensure privacy, replies and comments by individual users received anonymous codes. Post type is classified into one of five categories: status (text only), photo, video, link, or event.

The posts were then coded into Lovejoy and Saxton's (2012) InformationCommunity-Action framework for NGOs, which includes 12 categories. Two coders used this coding manual, and a double-coding process was utilized for the first 100 posts to ensure that discrepancies were discussed and coding rules were further refined. Each post was assigned to only one category based on its primary purpose for the communication. The inter-coder agreement was at $93 \%$ and a Cohen's kappa score of 0.91 , indicating a high level of inter-coder reliability.

For the purposes of this study, engagement is defined as the number of reactions (like, anger, etc.), comments, and the shares a post garners. Cho, Schweickart, and Hasse (2013) note that levels of engagement have a hierarchy. The highest level of engagement with a post is when others reply or comment to it. Sharing of a post is the second highest level of engagement followed by the least level of engagement that entails an expression of some kind of reaction to it. 


\section{Findings}

The majority of posts collected from both NGOs relate to the respective organization's mission. Sadagaat's posts focused primarily on its development and social services, while HSIs emphasized medically related services. The 570 posts fit well into Lovejoy and Saxton's Information-CommunityAction framework and reflected a professional and transparent use of information (Table 8.1). Both organizations shared information with their followers to inform and mobilize them to take action. They built a sense of community on their Facebook pages with followers through their interactions with them.

\section{Information}

The majority of Sadagaat and HSI's posts were informational $(57 \%$ of the entire sample). This is similar to how their Western counterparts use SNSs, echoing Lovejoy and Saxton's findings. The informational posts were used to update the public on the status of current initiatives, advertise the organizations' upcoming initiatives, and disclose financial information in the form of annual reports and program resources. The transparency in the disclosure of financial information by both Sadagaat and HSI is interesting because for the most part Sudanese organizations, both governmental and private enterprises, rarely if ever share such information. Both NGOs had real-time updates on their activities. For example, HSI had several informational posts (December 7-15, 2018) about two patients from the Darfur region brought to Khartoum for surgery. Followers were updated on the surgery and the post-surgery status of the patients. Sadagaat utilized the Live function on Facebook to visually chronicle the progress of several of its activities. A visual chronicle of one of Sadagaat's activities featured a wellestablished initiative, the "Ramadan Food Bags," which distribute food to families in need. The organization went live on April 28-29, 2019, to solicit donations and to show the massive numbers of food items that had already been donated and packaged. Three days later Sadagaat posted to its followers that food donations had tripled following the live coverage. This sharing of information reflects a transparent process where stakeholders can clearly see how their donations (money or in kind) are being used. Previous studies indicate that posting videos (especially live ones) and pictures engage existing followers and possibly attract new ones (De Vries, Gensler \& Leeflang, 2012). This particular live had 2,160 views, 54 comments, 208 reactions, and 44 shares. Sadagaat and HSI's posts received more engagement from their followers (in the form of replies and reactions) when they utilized videos or pictures in their posts rather than just posting a status.

Posts related to raising awareness of Sadagaat and HSI's philanthropic, social, medical, and educational initiatives accounted for $34.5 \%$ of informational posts, that is more than $59 \%$ of all informational posts. Sadagaat 
Table 8.1 Sadagaat and HSI Information-Community-Action framework

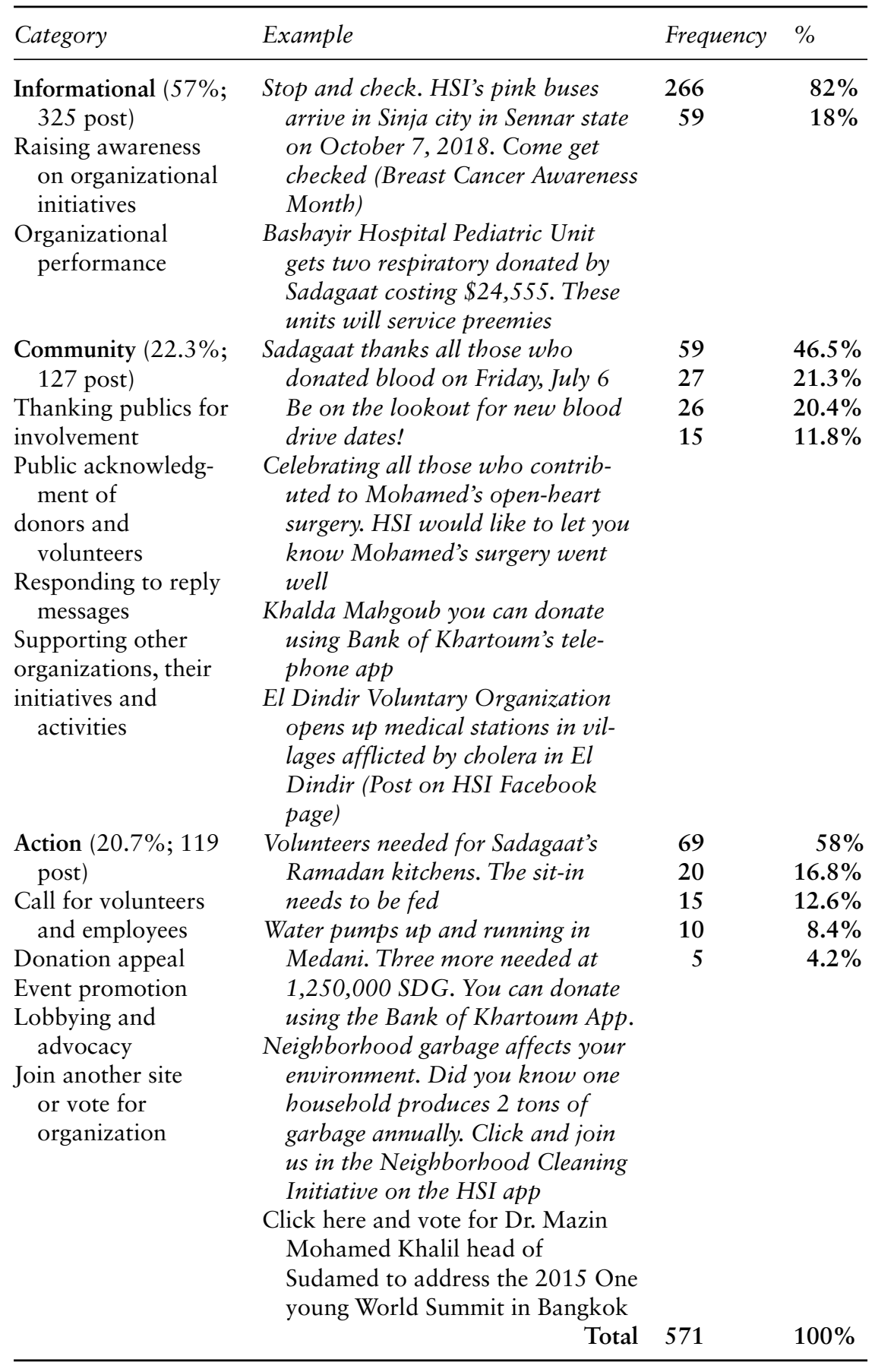


created its own Public Service Announcement (PSAs) videos in order to educate and inform stakeholders on issues pertaining to health care and public welfare. Its blood drive initiative in December 2018 was one of its most successful. A PSA was produced to raise awareness on the need to donate blood to blood banks because of the crumbling health care system. The PSA also advertised Sadagaat's forthcoming blood drive and was featured as a pinned post on the NGOs' page. The PSA gave all the relevant information on how to take part in the blood drive. The initial dates for the drive extended from December 20 to December 31, 2018. The Sudanese National Blood Bank reached its collection target by December 24, 2018, six days before the closing date. This huge success was attributed to Sadagaat publicizing and advocating for the initiative (Eliass, 2020).

\section{Building Community: Reaching Out to Stakeholders}

The community-based posts accounted for $22.3 \%$ of the sample. There were four types of subcategories for community posts: thanking public involvement in the organizations' initiatives and activities, public acknowledgment of donors and volunteers, responding to reply messages, supporting other organizations, and their initiatives and activities. Posts speaking directly to followers utilized a form of colloquial Arabic called Al Randok, a slang lexicon used by younger people in Sudan. The messages in the posts were serious, but the language utilized intentionally appealed to a specific demographic, younger followers. Sadagaat and HSI have both a broad appeal and reach within the Sudanese populace, but it is known that most of their initiatives on the ground are supported by young volunteers from both genders. The codeswitching seen in community-based posts indicates a strategic (intentional or unintentional) communication approach by Sadagaat and HSI; perhaps with the intent to create a sense of community and build long-lasting bonds with younger followers. Mutual understanding and communication enable organizations to build long-lasting relations and trust with their stakeholders whether they are donors or volunteers (Brown \& Kalegaonkar, 2002).

The majority of posts in the community category thanked the public for their involvement in the organizations' initiatives and activities $(46.5 \%)$. Perhaps this was used as a communication strategy to demonstrate to publics that initiatives do succeed when stakeholders work together.

Donors and volunteers were publicly acknowledged for the support they gave to Sadagaat and HSI. These posts accounted for $21.3 \%$ of all community posts. Sadagaat and HSI ensured that they responded to followers who commented on their posts ( $20.4 \%$ of all community posts). Symmetric communication is known to make publics feel that their input is appreciated and acknowledged, an important factor in building a long-lasting relationship between organizations and stakeholders (Breakenridge, 2012). Both Sadagaat and HIS paid it forward by showing support for other local NGOs by 


\section{Maha Bashri}

publicizing these entities' initiatives and events (11.8\%). Interestingly, only the work of local NGOs was shared on Sadagaat and HSI's pages.

\section{Action: Offline Mobilization}

NGOs tend to have less calls to action and more sharing of information and community-building with their followers through communication on their SNSs (Zhou \& Pan, 2016; Nah \& Saxton, 2013; Lovejoy \& Saxton, 2012). This was not the case for Sadagaat and HSI, whose calls to action posts were at about the same percentage $(20 \%)$ as their posts related to community-building.

The majority of posts in the call for volunteers and employees' category requested that citizens help with the initiatives $(58 \%)$. The finding is not surprising as it reflects Sadagaat and HSI's reality in fulfilling their missions; grassroots involvement is critical for initiatives to succeed. Posts calling for volunteers exponentially increased in number with the start of the December Revolution in Sudan. Interestingly, none of the calls made any direct political references, yet the initiatives were connected to events related to the December Revolution. For example, Sadagaat rallied followers to volunteer and help with food preparations intended for fasting civilians at the sit-in location. Sadagaat facilitated food preparations by setting up mobile kitchens throughout the capital Khartoum. Donations (monetary and in kind) are crucial for the two NGOs. Approximately $17 \%$ of calls-to-action were donation appeals. Monetary donations could be made either via online apps (developed by Sadagaat and HSI) or offline.

Sadagaat and HSI's calls to promote events were at $12.6 \%$, unlike their Western counterparts in Lovejoy and Saxton's study that tended to promote more events in their posts. This points to the fact that the objective of NGOs and civil society groups is different in Sudan's context. Only ten posts $(8.4 \%)$ were focused on lobbying or advocacy issues. These calls directly related to global events such as breast examinations during "Breast Cancer Awareness" month in October. The least number of posts in the call-toaction category focused rallying followers to join social media sites of other local NGOs $(4.2 \%)$.

\section{Discussion}

Sadagaat and HSI are utilizing SNSs in a similar manner to their Western counterparts. Information dissemination is the main function for their Facebook accounts. While Western NGOs might resort to such an approach because they do not necessarily recognize SNSs' potential for creating dialogue with their volunteers and donors, the case might be different in Sudan. First, Sudanese NGOs, unlike their Western counterparts, do not have websites; this is attributable to lack of resources. Their primary conduits for sharing information are their SNSs. Second, it is easier and much faster to 
update information on SNSs than it is on websites. Third, most of Sadagaat and HSI's volunteers are young netizens with a strong presence on SNSs. Sadagaat and HSI's Facebook pages serve the same role that websites do for Western NGOs; they are not complementary communication tools. It is a strategic communication approach to disseminate information where most of your stakeholders will seek it. Sudan's political context might have also dictated that these two NGOs restrict their posts only to informing stakeholders about their initiatives and their progress. The ousted Sudanese dictatorship would likely have clamped down on Sadagaat and HSI if their Facebook pages had blatant political discourse, bound to happen if community posts superseded informational posts.

Lovejoy and Saxton's framework offers a schema to examine communication patterns in NGOs with well-established organizational norms and processes. The transparent sharing of information by an organization with its stakeholders forges a strong relationship between both parties. Additionally, it enables organizations to demonstrate how their values align with stakeholder expectations, consequently gaining legitimacy for the organization. Studying Sadagaat and HSI's communication patterns through the lens of Lovejoy and Saxton's framework enables us to examine the transparency of their communication and in turn evaluate how their values align with those of stakeholders, a crucial factor in determining their organizational legitimacy.

As mentioned earlier in this case study, there is a deep wariness among Sudanese citizens regarding the credibility of institutions in Sudan. The lack of transparency and scarcity of reliable information has been the modus operandi of most Sudanese organizations. Organizations are moral actors whose actions are anchored by their objectives and missions. This becomes even more important when they exist in authoritarian contexts where sharing of information and transparency tend to be scarce. Since their inception, Sadagaat and HSI understood that organizations gain legitimacy with stakeholders if they share transparent and reliable information. Organizational legitimacy translates into a circle of trust. The information shared by the two NGOs pointed to deliverable projects on the ground. Ultimately, the information being shared had no political motive, yet success of Sadagaat and HSI's projects pointed to the government's shortcomings.

Community-related posts were also comparable in number to those of Western NGOs. However, the messaging on these posts was unique to Sudanese netizens, the primary audience for Sadagaat and HSI. The use of the Randok language appealed to and engaged young Sudanese netizens, allowing for the creation of spaces where dialogue between the NGOs and their followers could take place. As noted by Kelleher (2009), organizations maintaining open communication in a conversational manner with their stakeholders build trust and community. This strategic dimension of SNSs is an important factor in mobilizing stakeholders on the ground in the future (Breakenridge, 2012). Contrarily, Western NGOs tend to use the same language in all their posts, regardless of their function (Bortree \&Seltzer 2009). 


\section{Maha Bashri}

The analysis of the 571 posts on Facebook shows that while Sadagaat and HSI primarily used posts to inform stakeholders, there was an equal number of posts building community and calling publics to action. The implication here is that while Sadagaat and HSI aligned with their Western counterparts in using SNS platforms to inform stakeholders, they had more emphasis on calls-to-action because of their political and societal contexts. However, their calls-to-action were not blatant rallies to resist or change the government. They revolved mostly around support services, which were at times related to political events. For example, HSI called on all medical professionals to service the makeshift clinics it created in the December Revolution's sit-in area. These clinics treated citizens wounded by government security personnel.

Future research can expand on the findings in this case study to examine other NGOs in Sudan and their use of SNSs to communicate with stakeholders. More importantly, an examination of other models of communication in conjunction with that on SNSs is needed. The oral tradition and small group are prevalent communication models in Sudan. Audiences use other new media technologies, such as WhatsApp, in the same manner in which they communicate face-to-face. Small to mid-size groups of friends share information on platforms such as WhatsApp. The chitchatting and sharing of information that happens in the "real world" is now unfolding in digital settings. Friends and family members share and react to Sadagaat and HSI's Facebook communications through these small digital groups. These private interactions are very important in measuring the true impact of Sadagaat and HSI's communication with stakeholders as they play an important role in informing, building community, and mobilizing Sudanese audiences. It is beyond the scope of this study to capture these reactions in such groups. However, in the future, for better measurement and insights, Sudanese stakeholders' reactions to NGOs on other digital platforms need to be considered.

The analysis indicates that NGOs in Sudan have communication patterns on SNS platforms that are very similar to their counterparts in Western contexts. This demonstrates a high level of professionalism on the part of Sadagaat and HSI, but it also points to a political context where transparency and information are in high demand if organizations want to build a relationship with stakeholders who can be mobilized in the future. Despite an authoritarian government that heavily censored its citizenry, these two Sudanese NGOs earned organizational legitimacy through credible and transparent online communication with their stakeholders, setting an example for other groups in the country. The findings of this case study demonstrate that while it is relevant to non-Western contexts, Lovejoy and Saxton's Information-Community-Action framework should consider revisions based on the contextual and cultural dimensions of NGOs.

The Internet and SNSs are not necessarily a panacea to rally against authoritarian regimes. However, empirical evidence supports the fact that 
they open up alternative spaces for citizens and NGOs while being a catalyst for change on the ground.

\section{References}

Ahmed, A. M., \& A-Rahman, N. H. A. (2015). Hawadith Street Initiative: A unique Sudanese childhood charity experience. Sudanese Journal of Pediatrics, 15(2), 9. Retrieved from https://pubmed.ncbi.nlm.nih.gov/27493430/

Al Saadawy, A. (2013, February 13). Sadagaat: A charitable initiative reflecting the ability of individuals to serve society. Al Itihad Newspaper. Retrieved from https://www.alittihad.ae//article/12291/2013/\%c2\%ab\%d8\%b5\%d8\%af\%d9\% $82 \%$ d $8 \%$ a $7 \%$ d $8 \%$ aa $\%$ c $2 \%$ bb- $\%$ d $9 \% 85 \%$ d $8 \%$ a $8 \%$ d $8 \%$ a $7 \%$ d $8 \%$ af \%d $8 \%$ b1 1 d $8 \%$ a $9-\%$ d $8 \%$ ae $\%$ d $9 \% 8$ a $\%$ d $8 \%$ b1 \% d $9 \% 8$ a \% d $8 \%$ a $9-\%$ d $8 \%$ aa $\%$ d $8 \%$ b9 $\%$ d $9 \% 83 \%$ d $8 \%$ b3 - \%d $9 \% 82 \%$ d $8 \%$ af $\%$ d $8 \%$ b1 $1 \%$ d 8 \%a 9 - $\%$ d $8 \%$ a $7 \%$ d $9 \% 84 \%$ d $8 \%$ a $3 \%$ d $9 \% 81 \%$ d $8 \%$ b1 1 d $8 \%$ a $7 \%$ d $8 \%$

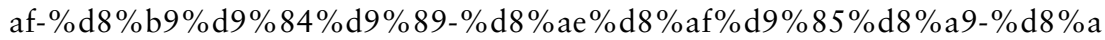
$7 \% \mathrm{~d} 9 \% 84 \% \mathrm{~d} 9 \% 85 \% \mathrm{~d} 8 \%$ ac $\% \mathrm{~d} 8 \%$ aa $\% \mathrm{~d} 9 \% 85 \% \mathrm{~d} 8 \%$ b9

Bashri, M. (2014). The use of ICTs and mobilisation in the age of parallel mediaan emerging fifth estate? A case study of Nafeer's flood campaign in the Sudan. Ecquid Novi: African Journalism Studies, 35(2), 75-91. https://doi.org/10.1080/0 2560054.2014.922111

Bilal, A. (2005). Social problems and civil society in Sudan (in Arabic). Khartoum, Sudan: Dar Azza.

Bortree, D. S., \& Seltzer, T. (2009). Dialogic strategies and outcomes: An analysis of environmental advocacy groups' Facebook profiles. Public Relations Review, 35(3), 317-319. https://doi.org/10.1016/j.pubrev.2009.05.002

Breakenridge, D. (2012). Social media and public relations: Eight new practices for the PR professional. Upper Saddle River, NJ: Pearson FT Press.

Brown, L. D., \& Kalegaonkar, A. (2002). Support organizations and the evolution of the NGO sector. Nonprofit and Voluntary Sector Quarterly, 31(2), 231-258. https://doi.org/10.1177/0899764002312004

Brysk, A. (2000). Democratizing civil society in Latin America. Journal of Democracy, 11(3), 151-165. doi:10.1353/jod.2000.0049

Campbell, D. A., Lambright, K. T., \& Wells, C. J. (2014). Looking for friends, fans, and followers? Social media use in public and nonprofit human services. Public Administration Review, 74(5), 655-663. https://doi.org/10.1111/puar.12261

Cho, M., Schweickart, T., \& Haase, A. (2014). Public engagement with nonprofit organizations on Facebook. Public Relations Review, 40(3), 565-567. https://doi. org/10.1016/j.pubrev.2014.01.008

Dawkins, J. (2004). Corporate responsibility: The communication challenge. Journal of communication management, 9(2), 108-119. https://doi.org/10.1108/136325 40510621362

De Vries, L., Gensler, S., \& Leeflang, P. S. (2012). Popularity of brand posts on brand fan pages: An investigation of the effects of social media marketing. Journal of Interactive Marketing, 26(2), 83-91. https://doi.org/10.1016/j.intmar.2012.01.003

Della Porta, D., \& Mattoni, A. (2015). Social movements. The International Encyclopedia of Political Communication, 1-8. https://doi.org/10.1002/9781118541555. wbiepc 010 


\section{Maha Bashri}

Diamond, L. (1994). Rethinking civil society: Toward democratic consolidation. Journal of Democracy, 5(3), 4-17. doi:10.1353/jod.1994.0041

Elbagir, Y. (2016, July 7) How Sudan's diaspora uses social media to marshal Ramadan meals. The Guardian. Retrieved May 25, 2019, from https://www.theguardian. com/world/2016/jul/07/sudan-culture-giving-galvanised-support-aid-donors

Eliass, A. (2020, February 13, 2020). Sudan's Vein. Al Adwaa Digital Newspaper. https://www.aladwaa.online/archives/3899

Etter, M., Ravasi, D., \& Colleoni, E. (2019). Social media and the formation of organizational reputation. Academy of Management Review, 44(1), 28-52. https://doi. org/10.5465/amr.2014.0280

Foley, M. W., \& Edwards, B. (1996). The paradox of civil society. Journal of Democracy, 7(3), 38-52. doi:10.1353/jod.1996.0048

Geser, H. (1992). Towards an interaction theory of organizational actors. Organization Studies, 13(3), 429-451. https://doi.org/10.1177/017084069201300306

Gleason, B. (2013). \# Occupy Wall Street: Exploring informal learning about a social movement on Twitter. American Behavioral Scientist, 57(7), 966-982. https://doi. org/10.1177/0899764012471585

Guo, C., \& Saxton, G. D. (2014). Tweeting social change: How social media are changing nonprofit advocacy. Nonprofit and Voluntary Sector Quarterly, 43(1), 57-79. https://doi.org/10.1177/0899764012471585

Ibrahim, H. (2001). Civil and traditional society in Sudan (in Arabic). Cairo: The Centre for Sudanese Studies

Keck, M. E., \& Sikkink, K. (2014). 1. Transnational Advocacy Networks in International Politics: Introduction. In Activists beyond borders (pp. 1-38): Cornell University Press. https://doi.org/10.7591/9780801471292-002

Kelleher,T. (2009). Conversational voice, communicated commitment, and public relations outcomes in interactive online communication. Journal of Communication, 59(1), 172-188. https://doi.org/10.1111/j.1460-2466.2008.01410.x

Kemp, Simon. (2020, February 18). DIGITAL 2020: SUDAN. Datareportal 2020. Retrieved May 6, 2021, from https://datareportal.com/reports/digital-2020-sudan

Kent, M. L., Taylor, M., \& White, W. J. (2003). The relationship between Web site design and organizational responsiveness to stakeholders. Public Relations Review, 29(1), 63-77. https://doi.org/10.1016/S0363-8111(02)00194-7

Knowledge@Wharton (2013, June 3). Wharton Business School Bulletin. Sadagaat: Bringing hope and professionalism into Sudan's social sector. Retrieved April 1, 2019, from https://knowledge.wharton.upenn.edu/article/sadagaatbringing-hope-and-professionalism-into-sudans-social-sector/

Lamoureaux, S., \& Sureau, T. (2019). Knowledge and legitimacy: the fragility of digital mobilisation in Sudan. Journal of Eastern African Studies, 13(1), 35-53. https://doi.org/10.1080/17531055.2018.1547249

Lovejoy, K., \& Saxton, G. D. (2012). Information, community, and action: How nonprofit organizations use social media. Journal of Computer-Mediated Communication, 17(3), 337-353. https://doi.org/10.1111/j.1083-6101.2012.01576.x

Lovejoy, K., Waters, R. D., \& Saxton, G. D. (2012). Engaging stakeholders through Twitter: How nonprofit organizations are getting more out of 140 characters or less. Public Relations Review, 38(2), 313-318. https://doi.org/10.1016/j.pubrev. 2012.01.005

Macnamara, J. (2010). Public communication practices in the Web 2.0-3.0 mediascape: The case for PRevolution. PRism, 7(3), 1-13. 
Nageeb, S. A. (2006). Building the Sudan of peace: Negotiating development and Islam in Sudan. Sociologus, 56(2), 225-253. Retrieved from https://www.jstor.org/ stable/43645577

Nah, S., \& Saxton, G. D. (2013). Modeling the adoption and use of social media by nonprofit organizations. New Media \& Society, 15(2), 294-313. https://doi. org/10.1177/1461444812452411

Othman, M. M. (2015, November 28th, 2020). Shari'a Al Hawadith a medical organization helping those in need. BBC Arabic Report. Retrieved from https://www. bbc.com/arabic/multimedia/2015/05/150529_sudan_health_voluntary

Quinton, S., \& Fennemore, P. (2013). Missing a strategic marketing trick? The use of online social networks by UK charities. International Journal of Nonprofit and Voluntary Sector Marketing, 18(1), 36-51. Retrieved from https://doi.org/10.1002/ nvsm. 1450

Rieder, B. (2013). Studying Facebook via data extraction: The Netvizz application. Proceedings of WebSci '13, the 5th Annual ACM Web Science Conference, 346355. https://doi.org/10.1145/2464464.2464475

Rosen, S. (2010). China Media Colloquiuml Is the Internet a Positive Force in the Development of Civil Society, a Public Sphere and Democratization in China? International Journal of Communication, 4, 8. Retrieved from https://ijoc.org/ index.php/ijoc/article/view/749/426

Salih, M. A. M., \& Swar, M. O. (2015). Lessons to the World: Sudanese youth and the wellbeing of children. Sudanese Journal of Pediatrics, 15(2), 6.

Saxton, G. D., Guo, S. C., \& Brown, W. A. (2007). New dimensions of nonprofit responsiveness: The application and promise of Internet-based technologies. Public Performance \& Management Review, 31(2), 144-173. DOI: 10.2753/ PMR1530-9576310201

Saxton, G. D., \& Waters, R. D. (2014). What do stakeholders like on Facebook? Examining public reactions to nonprofit organizations' informational, promotional, and community-building messages. Journal of Public Relations Research, 26(3), 280-299. https://doi.org/10.1080/1062726X.2014.908721

Suchman, M. C. (1995). Managing legitimacy: Strategic and institutional approaches. Academy of Management Review, 20(3), 571-610. https://doi.org/10.5465/ amr.1995.9508080331

Svensson, P. G., Mahoney, T. Q., \& Hambrick, M. E. (2015). Twitter as a communication tool for nonprofits: A study of sport-for-development organizations. Nonprofit and Voluntary Sector Quarterly, 44(6), 1086-1106. https://doi. org/10.1177/0899764014553639

Waters, R. D., \& Jamal, J. Y. (2011). Tweet, tweet, tweet: A content analysis of nonprofit organizations' Twitter updates. Public Relations Review, 37(3), 321-324. https://doi.org/10.1016/j.pubrev.2011.03.002

Weber, M. (1978). Economy and society: An outline of interpretive sociology (Vol. 1). University of California Press.

Weberling, B., Waters, R., \& Tindall, N. (2012). The role of text messaging in public relations: Testing the situational theory of publics for mobile giving campaigns. In S. Duhe (Ed.), New media and public relations (pp. 189-197). New York: Peter Lang.

Zhou, H., \& Pan, Q. (2016). Information, community, and action on Sina-Weibo: How Chinese philanthropic NGOs use social media. VOLUNTAS: International Journal of Voluntary and Nonprofit Organizations, 27(5), 2433-2457. https://doi. org/10.1007/s11266-016-9685-4 


\title{
9 Theorizing Feminist-Democratic Media Activism via NGO Media Activism in South Africa
}

\author{
Giuliana Sorce
}

Inequality in media is a global issue. Around the world, patriarchal and capitalist media industry structures center the needs of the wealthy and powerful. Media messages perpetuate disadvantaging images and contribute to social marginalization. Inequality in media denies participation, misrepresents identities, erases experiences, and silences voices. In order to combat issues such as mediated misrepresentation or regime-driven media policy, activism is needed. Media activism scholars employ a multitude of methods to cover a plethora of geographical and cultural contexts-existing research ranges from case studies of media activist groups (Min \& Kim, 2012) and non-governmental organizations (Sorce, 2019c) to strategic analyses that investigate social media (Bosch, 2017; Chan, 2016) or data(fied) activism (Barassi, 2016; Milan, 2013) in grassroots initiatives.

Globally, NGOs play an important role in social change initiatives and have gained increasing interest within media and communication studies (e.g., Imison, 2014; Ngai, 2017; Ruelle \& Peverelli, 2017). While existing scholarship has theorized certain types of media activism (Carroll \& Hackett, 2006; Hackett \& Carroll, 2006; Byerly \& Ross, 2006; Milan, 2013; Treré, 2018), researchers continue to struggle locating analytical frameworks that can grasp what is often a wide range of NGO activist activities steeped in particular political and sociocultural complexities. When it comes to activism by media-oriented NGOs, theorizing is still scarce.

In this chapter, I employ institutional ethnography to offer a theoretical framework for studying NGO-based media activism that is grounded in activist experience. Taking the activity of a successful South African media activism NGO as a launching point, this chapter develops feministdemocratic media activism (hereafter FDMA) as a theory that makes visible the democratic and feminist values inherent to NGO activism in the media sector of the Global South-including critiques of media power, political economy, access and participation, and intersectional media representation. In building theory from activist practice and activist experience, FDMA reflects the organizational values and the values of NGO workers, which includes how they understand the main issues in the mediascape, how they

DOI: $10.4324 / 9781003188636-12$ 
organize and plan activities, and how communication and media figures into their action repertoire.

By integrating theoretical contributions from feminist activist theory (participation, equity, diversity, representation) and democratic media theory (people-centered media economy and policy), FDMA provides a frame to assess NGO activist activities, organizing, strategies, and impacts. In offering ethnographic insights from an impactful NGO, FDMA hopes to furnish a theoretical lens that enables the cross-cultural, cross-organizational, and multi-sited comparisons we are currently seeking. In order to situate FDMA as a viable theoretical construct that can capture the activities, strategies, and organizational identity of media activist organizing, this chapter provides a case study of "Media Monitoring Africa" (MMA), one of the most influential and well-known media NGOs in South Africa.

\section{"Media Monitoring Africa”}

MMA was founded out of the central concern that the national public broadcaster (South African Broadcasting Corporations) would not cover the first democratic elections of 1994 fairly due to its long history of government censorship. For over 25 years now, MMA has been monitoring South Africa media, organizing activist campaigns, and overseeing litigation procedures with oversight structures that were put in place to enable a fair media system. MMA recognizes the reciprocal relationship between media representation and production-the NGO seeks to help democratize the media system while improving ethical media content that reflects diversity and meets the highest standards of journalistic integrity. Per MMA's mission statement, these efforts "will ultimately lead to citizens, media and the powerful respecting a culture of human rights and thereby encouraging a fair and just society" (About Us, Media Monitoring Africa, n.d.). MMA's social justice-based approach could not be described other than feminist at its core-the NGO is invested in participation of diverse voices, with equal and intersectional representation. At the same time, MMA highlights the importance of media access, freedom, and quality—all values of media democratization.

Through its unique activist success and transnational rapport, MMA has also generated scholarly interest. Van Zyl and Kantor (1999) provide an overview of the role of media activism during the apartheid transition in South Africa and draw on the work of MMA-then called the "Media Monitoring Project." The authors suggest that the NGO's election monitoring was pivotal in underscoring the importance of media monitoring in democratizing societies. In particular, they laud MMA's ability to advocate for media that center the needs of the diverse South African people while highlighting the importance of a democratic media industry. In my own work with MMA, I have argued that the NGO has been able to weave into the fabric of the South African mediascape through consistent yet innovative 
activism, thereby securing an advantageous position for their campaigns (Sorce, 2019c).

Other scholars have focused on the feminist implications of MMA. Gallagher's (2001) book project discusses MMA's research that highlights gender misrepresentation and the missing involvement by women in the news media right after the apartheid era. She uses MMA's work to make her case for the continuing need for media monitoring and media activism. Another feminist global media scholar, Geertsema (2010) includes testimony from the Director of MMA in her study of gender-based activism. MMA has also been the NGO behind the 2010 and 2015 reports of the largest global initiative to monitor the state of women in media organizations and content-the Global Media Monitoring Project (GMMP). The GMMP is internationally recognized project for its work on monitoring, analyzing, and thus raising awareness on the global gender parity in media (Gallagher, 2001; Vega Montiel \& Macharia, 2018). It is activism like this that makes MMA's commitment to feminism readily evident.

\section{What Theories for Media NGO Research?}

Media activism is defined to include the broad-based, non-hierarchical organizing through (digital) networks as well as grassroots or organization-led initiatives that seek social justice on a range of topics (Sorce, 2019b). The call to theorize activism, however, has been echoing through various areas in our discipline for the better part of two decades (Adelman \& Frey, 2000; Chávez, 2013; Croteau, 2005; Frey \& Carragee, 2007; Rodino-Colocino, 2012). Scholars have done so from various perspectives and with various emphases-media activism, media advocacy, media democratization, media liberalization, media reform, media intervention, media transformation, media justice, and communication rights are just some of the concepts literature in the area has yielded. Collectively, these terms advocate for equality and democracy as the overarching narrative and underscore the importance of an accessible mediascape that centers the interests of the people, reflects a plurality of voices, and remains free from government control.

Yet, Bennett (2017) critiques that media activism research dominantly focuses on case studies and particular strategic communication practices rather than working to expand our conceptual understandings about media activism's underlying ideals:

It may be useful for the development of the field, however, to add more explicit normative frameworks: principles of democratic activism, evaluation standards for various media strategies, and ways of talking about outcomes that enable comparisons across different sectors. These standards will help a field that is deeply concerned about values be more explicit about what those values are, and how to raise them to analytical frameworks. 
He calls for the development of value-driven theories that harness experience-based evidence to furnish perspectives that also enable comparative scholarship. For MMA's NGO activism in South Africa, both democratic and feminist values play a key role. But what theor(ies) capture these values and activities?

In what they theorize as "democratic media activism" (hereafter DMA), Hackett and Carroll (2006) explain that media activists engage with media stakeholders on various levels, including the institutional setup of media organizations, the production process, the content, the audiences, and the cultural environment (pp. 85-86). Further, the authors provide three strategies for DMA through collective action. The first is to "reform or revamp the media field internally," which would involve media professionals taking collective action through unionization and a self-determined focus on ethical critical investigation (p. 52). A second strategy is to "create new and parallel fields," which involves the creation and financial support of alternative media. Finally, a third strategy is to implement policy change, media literacy education, and foster media advocacy groups.

The DMA approach engages a systemic perspective that hinges on democratization of the mediascape at large, which does not hold in its core cultural transformations that respond to issues of representation or equal participation by marginalized voices. However, the specific work of media NGOs with social change and equity agendas often falls in between systemic and cultural critiques. Organizations such as MMA exist in the "border zones, at the seams between system and lifeworld," in sites can become catalysts for "social movement formation and challenges to system logic" (Hackett \& Carroll, 2006, p. 55). As such, NGOs working on media activism require an integrative theoretical approach that can also capture cultural issues surrounding the signification work of media texts.

Feminist theorizing about media activism latches onto the cultural critique with a focus on gender. This line of theorizing critiques the lack of women's involvement in the production of media, misrepresentation of women in media texts, and the resulting cultural marginalization. Importantly, intersectional perspectives have offered additional layers to doing activist work in contexts such as queer migration (Chávez, 2013) or black liberation (Jackson, 2016). In their model of women's media action, Byerly and Ross (2006) seek to "illustrate how women manifested their agency in creating ... a feminist public sphere" (p. 100). Their findings yield that women activists primarily aspire to increase the amount of information about women available in the media and to stop media stereotyping. Second, the authors found that participants seek to mobilize other women and increase the coverage about women in media. Byerly and Ross thus argue that their model fits "any organized effort on women's part to make changes in established media enterprises or to create new media structures with the goal of expanding women's voice in society and enabling their social advancement" (p. 101). 
For the South African context in particular, however, Geertsema (2010) found that the "professional-technical approach" to feminist media activism, such as "gender mainstreaming," does not facilitate long-term impacts in patriarchal cultural values (p. 84). As a media activist NGO, MMA employs monitoring as a main activist tool. Gallagher's (2001) book project on media monitoring and advocacy situates the necessity and goal for monitoring groups in the critique and creation of symbolic visibility for women. Within the scope of a feminist critique, she roots media advocacy in the form of monitoring as "based on the belief that the public can play a role in determining what stories are told, and how" (p. 8). Hoynes (2005) explains that media monitoring and research "produces knowledge that has a cultural authority that activism lacks" (p. 107). Yet, MMA has been able to situate itself as an element of the South African mediascape despite the fact that the NGO employs activist communication and action repertoires (Sorce, 2019c).

This study of MMA responds to Bennett's (2017) call for media activism theory by showcasing how activist practice can become a site for theorybuilding while paying particular attention to the core values that shape media NGO organizing. As noted by Gallagher (2001), scholars should keep in mind the push and pull of theory and praxis, and between action and research: "It is this reciprocity between action and research that defines feminist media studies and that contributes to its intellectual and political force" (p. 14). In this study, I synthesize participant knowledge inductively in order to let lived experiences become reflected theory and translate praxis into conceptual ideas that have the potential to inform other contexts and activist-oriented research projects. By basing theory on experiences and actions beyond the Western context, this study is also an attempt to let activists speak from the margins and decolonize African knowledge production (Willems, 2015).

\section{Studying NGO Media Activism Through Institutional Ethnography}

In order to study MMA's particular activist case in South Africa, this project employs an ethnographic approach. Scholars have studied NGOs through ethnography in order to provide descriptions about their specific behaviors, rituals, or practices (Lewis, 1998; Lewis, 2003; Fisher, 1997; Markowitz, 2000). However, these approaches cannot provide insights into how the NGO's activities relate to structural dimensions in an institutionalized context, such as the media. MMA is a culture-sharing group and I was interested in learning about the NGO's practices and values along with its team members' experiences and convictions. At the same time, this meant relating practices and experiences to the larger systemic structures in the South African mediascape to understand how these values emerge.

Canadian feminist sociologist Dorothy E. Smith coined an ethnographic methodology that is born out of a feminist paradigm shift (Smith, 1974) 
and seeks to account for the underlying factors that embed research participants in certain sets of social organization. Smith (1987) calls this methodology institutional ethnography (hereafter IE), explaining that this approach focuses on uncovering the various "ruling relations" that affect all aspects of our social experiences (see also Smith, 2005; 2006). These relations, she explains, are mediated by institutionalized processes "which together organize, coordinate, regulate, guide, and control contemporary societies" (Smith 1987, p. 152). One of those institutionalized ruling relations that mitigate social experience is the media (Sorce, 2019a).

After previous interactions with MMA while co-leading a study abroad program to South Africa, I had been impressed by the prominent position the NGO was able to secure with stakeholders such as the public broadcaster, print newspapers, and online media organizations. I returned in 2016 for a six-week stay in Johannesburg, where I was welcomed as a visiting scholar and provided access to MMA's proprietary monitoring software, sat on meetings, and aided in the production of reports. This immersion into the daily routines and culture at MMA allowed me a unique standpoint for this IE of NGO media activism in South Africa.

During my time in Johannesburg, I employed three data gathering techniques. First, participant-observations of MMA's daily routines, activities, and organizational processes, among others recorded at team meetings or special events with other activist groups. Second, individual interviews with all members of MMA, including members of their Board of trustees, as well as media professionals and other activist organizers whose NGOs maintain coalitional ties with MMA (a total of 23 recorded conversations). Third, I conducted textual analyses of MMA's public communications, including their website statements, promotional materials, and other organizational documents. Building on this data, and in the spirit of inductive research, I develop FDMA as a theoretical reflection of MMA's organizational activities and experiences around three central values: activist identity and practice, media democratization for public interest, and fostering feminism through projects and organizational identity.

\section{The Activist Values of Media NGOs}

The impetus behind MMA's formation was South Africa's transition to democracy from the segregational system of apartheid. The public broadcaster played a key role in the maintenance of the regime and was used as a mouthpiece for the government (Sparks, 2009). In that sense, MMA's very existence is political, as an oversight structure that monitors and intervenes. MMA's intervention and campaigns are rooted in a monitoring approach, which translates into specific activist practices, such as legal actions or protesting activities. 


\section{Organizational Identification}

The Chairman of the MMA Board, Prof. Tawana Kupe, immediately explains: "The core of what they do is monitoring ... but they do much more than monitoring. They also do advocacy." He explains advocacy in terms of their structural activism with the South African Broadcasting Corporation (SABC), the nation's public broadcaster: "We're big on media advocacy. . . . That is why we're right now at the forefront of the SABC cases." What becomes clear from the Chairman's description of MMA's advocacy work is that he strongly associates it with their mission to improve the political economic structures of the South African mediascape. In their individual indepth interviews, many MMA members identified the links between media monitoring ("the research") and the NGO's activist activities. As Hoynes (2005) explains, media monitoring is often a "critical component" of media activism (p. 107). At MMA, media monitoring is the basis for media critiques and activism. The Chairman explains:

By monitoring, you get the empirical evidence of what's happening. Based on that empirical evidence ... you either promote good practices, or you campaign against bad practices in order to improve the broader media environment and promote freedom of expression.

MMA monitors and analyzes activities in the South African mediascape. On the basis of these analyses, MMA members coordinate activist activities. Phakamile, a social media coordinator for the children's project, correspondingly notes: "You see, we do the research and then we can go out and say 'This wasn't fairly reported.' We never protest without monitoring evidence."

The interview prompt around MMA's identification as a media activist organization received overwhelming enthusiasm from interviewees. Motshabi recalls the first time she heard of MMA: "They were known for their activism ... ensuring that journalists cover topics fairly and with balance ... and holding the SABC accountable." She further explains that MMA's relationship with activism was something that "drew" her to the organization. Similarly, Mike recounts that he first learned about MMA during his introductory media studies seminar at the University of the Witwatersrand. He explains: "We read about them in our textbook.... I think the textbook said they did research and activism . . . yes, activism, I remember." Wellington summarizes:

By and large, I think the work that we do is activism. Whether you call it that or you don't call it that is another thing. ... Some would consider activism as getting dirty and being in the streets and running around. Which we do, time and again, with our picketing and all of that, but 
mostly our work is around analyzing content, and that's activism. Litigation and advocacy, that's activism, so I think we are. Whether we call ourselves that is something else.

\section{Interpersonal Identification}

MMA members personally identify with activism as well as denote MMA "as an activist organization." Amanda summarizes: "I am personally very interested in activism. Back in Australia, I have always worked with organizations ... LGBT and community initiatives, for example." Similarly, Motshabi articulates that her own experience as a "black woman underserved by relevant media programming" spurred her interest in doing activist work herself.

With the exception of one MMA team member, all NGO employees identify MMA as a media activist organization, though many later softened their statements and favored the term "advocacy." Amanda, a communications officer at MMA explains this when she contemplates the connotations of activism: "Someone might hear 'agitator' or 'protester', rather than someone who wants to get the public's attention by saying: 'Hey, they're covering this wrong and this affects you." Thandi, leader of the media policy unit at MMA, also notes that the term "advocacy" might be a cultural preference. She recounts her own experience of watching her parents protest during the apartheid era, explaining that these memories give her a very specific "notion of what activism is, and what it requires of people . . untiring attention and energy, always involved in the cause, instigating true political change."

Throughout the conversations with MMA members, interviewees continuously underscored how they personally relate to activism. For an NGO that engages in contentious actions surrounding media issues, a close-knit team with aligned value orientations is key. Louis, Amiot, Thomas, and Blackwood (2016) suggest that "greater activist identification" leads to "stronger intentions" to engage in activism, and to increase the "activist social network size" (p. 244).

\section{Activism as Practice}

While MMA members often describe MMA as a "watchdog" or "monitoring" organization, both activism and advocacy are an integral part of their organizational identity. Clarifying these two terms is important, as interviewees explain their own definitions of the two terms and how they relate to MMA's work. In the academic literature, the terms "media activism" and "media advocacy" are often used interchangeably, though scholars might have a personal term preference that influences the term they choose (see also Croteau, Hoynes, \& Ryan, 2005; Jansen, Pooley, \& Taub-Pervizpour, 


\section{Giuliana Sorce}

2011). In the case of MMA, the NGO facilitates advocacy and performs activism. Special programs coordinator Carol explains how she relates to activism and advocacy:

An activist is somebody [who] is willing to lobby even their own neighbor to adopt a particular idea. Yes, there's activism [at MMA]... . Advocacy to me is on someone else's behalf, and activism is directed to a particular community.

As Carol's testimony shows, activism is part of civic engagement, built into the sociocultural fabric of democratic societies, with the goal of immediate social or political change. Advocacy, then, is often on behalf of others, where people or organizations lobby, advocate, raise awareness, or litigate for external entities. In the case of MMA, they do both. An example of MMA's advocacy work is when MMA performs media monitoring for a nonprofit to help them secure funding for their community media projects. Advocacy, however, does not fit the scope of MMA's activities when MMA members take to the streets and protests.

MMA frequently engages in protests and picketing-a clear form of activism and a classic action repertoire in social movements (Tarrow, 2006; Tilly, 2000). As a form of collective action, protesting is also employed by social change NGOs. Motshabi, a newly hired social media editor and rural media literacy coordinator at MMA, recalls:

I came to MMA right about when [Communications Minister] Muthambi put herself and [President] Zuma in charge of the SABC. One of the first things I did as a new team member with MMA was tape a big " $X$ " over my mouth and go to Constitution Hill to protest [media] censorship.

Mike similarly summarizes that protesting is "the best outlet for civil society organizations to make their demands heard to the media corporations." In sum, MMA engages in activism on issues such as government censorship or media regulation.

What becomes clear from conversations with members of MMA is that activist ideals and activist work manifest in three ways: MMA members reveal their own personal identifications and experiences with activism, denote the organization itself as an activist organization, and identify activist actions (such as protesting) a key contentious action of their NGO work. These lived experiences translate to theorizing in that they identify three core values of doing media activism work on the level of activist practice alongside personal and organizational identification with an activist identity.

\section{The Democratic Values of Media NGOs}

As an NGO with a main focus on the media, MMA pursues media democratization in various ways - the NGO engages in media reform campaigns to 
improve industry structures, launches educational programs to foster more equitable conditions in newsrooms, and also advocates for citizen-oriented media policy and regulation, to name a few. Thandi's testimony about the historical importance of activism in South Africa's particular context leads to the discussion of democracy in the South African mediascape-one that has been undergoing the process of reform and democratization since the end of the apartheid regime (Barnett, 1999; Hadland, 2011; Sparks, 2009; Teer-Tomaselli, 2006). A core concern, according to MMA's Director, is the public broadcaster, the SABC.

\section{Media Democratization}

An illustrative example from my field work with MMA concerns the SABC crisis under former President Jacob Zuma (2009-2018). This particular encounter between the NGO and the public broadcaster showcases that a central democratic value of media NGO activism concerns democratic media policy and a media industry that operates in the interest of the public. In 2015, Zuma and his former Communications Minister Faith Muthambi (2014-2017) passed an amendment that granted the South African government exclusive power to appoint and regulate the SABC Executive Board. This board is not only in charge of programming decision-including the prime time news hour-but also oversees the digital news media channels and public radio stations across South Africa. In 2016, the SABC Executive Board terminated eight journalists to align the public broadcaster's newsrooms closer with the African National Congress (ANC), the governing party.

In direct response, MMA launched an institutional suit based on constitutional laws that specifically forbid government control of media and also demanded an official inquiry through the Independent Communications Authority of South Africa (ICASA), a regulatory body that ensures broadcasting in the public interest. As Mike explains: "The Constitution grants ... non-governmental organizations to lobby for issues that are in the public's [interest] and to try and create pressure around that." In addition, MMA helped launch a coalitional campaign that organized protests against SABC censorship, together with the Freedom of Expression Institute (FXI) and the Right 2 Know Campaign (R2K). As Amanda explains: "The SABC's power is forceful and stable... Through the protests, people will know that this is an issue that pertains to them."

At the subsequent ICASA hearing, MMA Director William and Head of Policy Thandi delivered the four coalitional demands for the future of media policy at the SABC: First, to immediately reinstate the eight terminated SABC journalists; second to prohibit Muthambi's SABC policy that prevents the public broadcaster from covering protests; third, the removal of Hlaudi Motsoeneng as SABC Chief Operating Officer; and lastly, to dissolve the SABC Executive Board appointed by Muthambi and President Zuma. Both William and Thandi recall this experience as an act of "activism" where 
"we acted as MMA to actively ensure that the SABC serve the people, not the government."

\section{Public Interest Media Advocacy}

MMA's actions around the SABC crisis reveals the NGO's commitment to democratic values that underscore the importance of third-sector organizations to advocate on behalf of public interest. The NGO also actively makes use of activism, such as protesting and litigation, to challenge government control of the media. A free, democratic, and public interest media industry is understood as the cornerstone of a democratic society and with it values such as people-centered policy and balanced programming require activism. To intervene in the very structures of the South African mediascape is democratic media activism (Hackett \& Carroll, 2006) that goes beyond sporadic campaigns. MMA's organizational practice reveals that continuous monitoring, oversight, and activist action is needed to ensure that media operate in the interest of the public.

\section{The Feminist Values of Media NGOs}

As a monitoring organization, MMA operates as an oversight NGO that bases its activist programs and special campaigns on content analyses of media reporting. MMA has invested into a proprietary content analysis tool that runs online, called "Dexter." This tool aggregates news texts from the salient news outlets in South Africa (public and commercial) and media monitors at MMA can upload transcriptions of radio and television newscasts in all nine official languages. Monitors can then search the data corpus for keywords, repetitions, and assigned tags. These content-based insights then serve as the basis for MMA's monitoring reports, for example, to reveal how election news coverage critically omits gender issues. The NGO thereby recognizes media's pivotal role in cultural understandings of identity and how more equitable representation can facilitate more positive perspectives.

\section{Fostering Equality as a Goal}

MMA has had a "Gender in the Media" project since its inception. "It was a big part of our very first monitoring exercise," William explains. The project includes content analyses that point out misrepresentation in media content (Banjac \& Dibetso, 2014) and interview-based studies of gender-based workplace discrimination in South African media corporations (Dibetso, 2013). Mike further explains that MMA's "research on women in the media also focused on gender-based violence." While the "Gender in the Media" special project specifically has feminist goals, MMA has found ways to bring feminism into other projects and special programs. 
An analysis of MMA's organizational documents reveals that $15 \%$ of MMA's total published reports specifically focuses on gender, which include both structural inequalities in the newsroom and content-specific critiques. Aya explains: "We are constantly also seeking out opportunities [for] projects that speak to gender, but also the empowerment of women, or improving how media report and how people understand feminism, understand gender, and related issues." Additionally, $80 \%$ of the remaining special project reports, though not specifically focused on gender, centers goals of diversity and equality. Aya explains: "[E]ven in our analyses [of] our media monitoring that we do on an ongoing basis ... we all consider feminist views in the media, gender-related matters, how the media communicate these, and how they are understood."

\section{Organizational Feminism}

Beyond representational aspects, MMA members also began connecting their activist and democratic values to feminism. Wellington explains: "I think we do activism as a human rights-based organization, and I know to me, feminism falls within that frame... . Our ideals as an NGO, yeah, they do fall into that [feminism]." In their individual interviews, MMA members addressed the question of feminism in two different ways: the organizational structure of MMA and feminist work culture. The conversations included discussions about how many women (of color) worked at MMA, how they contribute, why they are important, and why intersectionality in workers makes an organization stronger. We also discussed how MMA lets its team members set their activist agenda and how the organization's minimization of hierarchical decision-making allows for multidirectional input.

MMA members' identification of the NGO as a "feminist organization" is just as important as the feminist goals of their actual activism. Aya explains: "As a culture and how we interact with one another. You don't see the same linear power structures that you see perhaps in other organizations." This identification stands in sharp contrast to the dominant critiques in feminist organizational studies, where scholars continuously lament the hierarchies, gendering, and sexism present in organizations (Acker, 1990; Calás \& Smircich, 2005). The interview data suggests that MMA's denotation as a "feminist organization" also becomes emblematic of how workers' feminist ideals can translate into intersectional, equity-driven hiring practices for NGOs.

During a conversation with three MMA monitors, we brainstormed together what feminism means to them. Thandi comments, "feminism . . . it's challenging the dominant ideologies of male representation." Aya adds an intersectional perspective:

Gender, definitely ... also the LGBTI community, which has a difficult cultural standing in South Africa ... And with that, I would consider race to be a feminist issue, as well as class . . . socioeconomics. I think 
it does cut across those categories. It's not just looking at the empowerment of women, but you need to understand there are various issues that affect different groups that need to be paid attention to when you look at feminism as a whole.

It is this acute intersectional awareness of identity, difference, and equity that yield interpersonal identifications with feminism as a social ideal at MMA. Carol discusses the role of race and class for MMA's organizational profile. She explains: "I was the first poor black woman from Soweto to work at MMA. My being here was political. I hope when they find a replacement for me, they will consider another poor black woman. We are needed for perspective." Scholarship on intersectional hiring practices and workforce composition dovetail with Carol's plea (Acker, 1990; Healy, Bradley \& Forson, 2011).

While MMA promotes feminism through its activism and internal organization, the language of feminism remains absent in their public communication. Instead, MMA has formulated a "Theory of Change" (Media Monitoring Africa, n.d.; see Figure 9.1) that maps the path to citizencentered media by advocating for ethical and equitable media that hold the powerful accountable. Yet, the formulation in itself is feminist because its social change agenda centers people-regardless of gender, race, class, ethnicity, age, or ability. Ferree and Martin (1995) explain that many NGOs have feminist goals but do not articulate them in their mission statementsa "tactical" omission to avoid backlash (see also Harding, Fort \& Fotaki, 2013). Amanda explains: "It's similar to activism in the sense that the word 'feminism' spooks people.... [T] hey hear 'radical' rather than someone who wants to find out why policy entrenches patriarchy."

MMA enacts its "Theory of Change" through specific activist projects that tackle gender misrepresentation and inequities in the structure of the mediascape. MMA Director William explains: "We exist because we know that inequity in media exists. Whether it is around gender, or race, the problems are there and at MMA, we try to fix how these issues pan out in our media." Wellington also describes MMA as a human rights based organization, but one that promotes a feminist mission. Thandi similarly explains: "We deal with issues of race, issues of gender, issues of class and marginalization. We see ourselves as fighting for those rights, and you can't separate that from feminism." William recounts an early experience with news editors where their gender report laid bare the pervasive misrepresentation and its cultural implication: "On every angle we hit them, nailed 'em completely. . . . Then we were surprised that they didn't wanna see us again.” As Hoynes (2005) explains, a "less blame-oriented approach" (p. 105) opens up more opportunity for productive dialogue between stakeholders-a lesson that MMA has learned. William's description of the negotiation of activism and feminism also specifically speaks to the cultural environment in which MMA operates. Amanda notes: "You're 


\section{MEDIAMONITORING THEORY OF $\because$ O O O AIJEICHAl CHANGE}

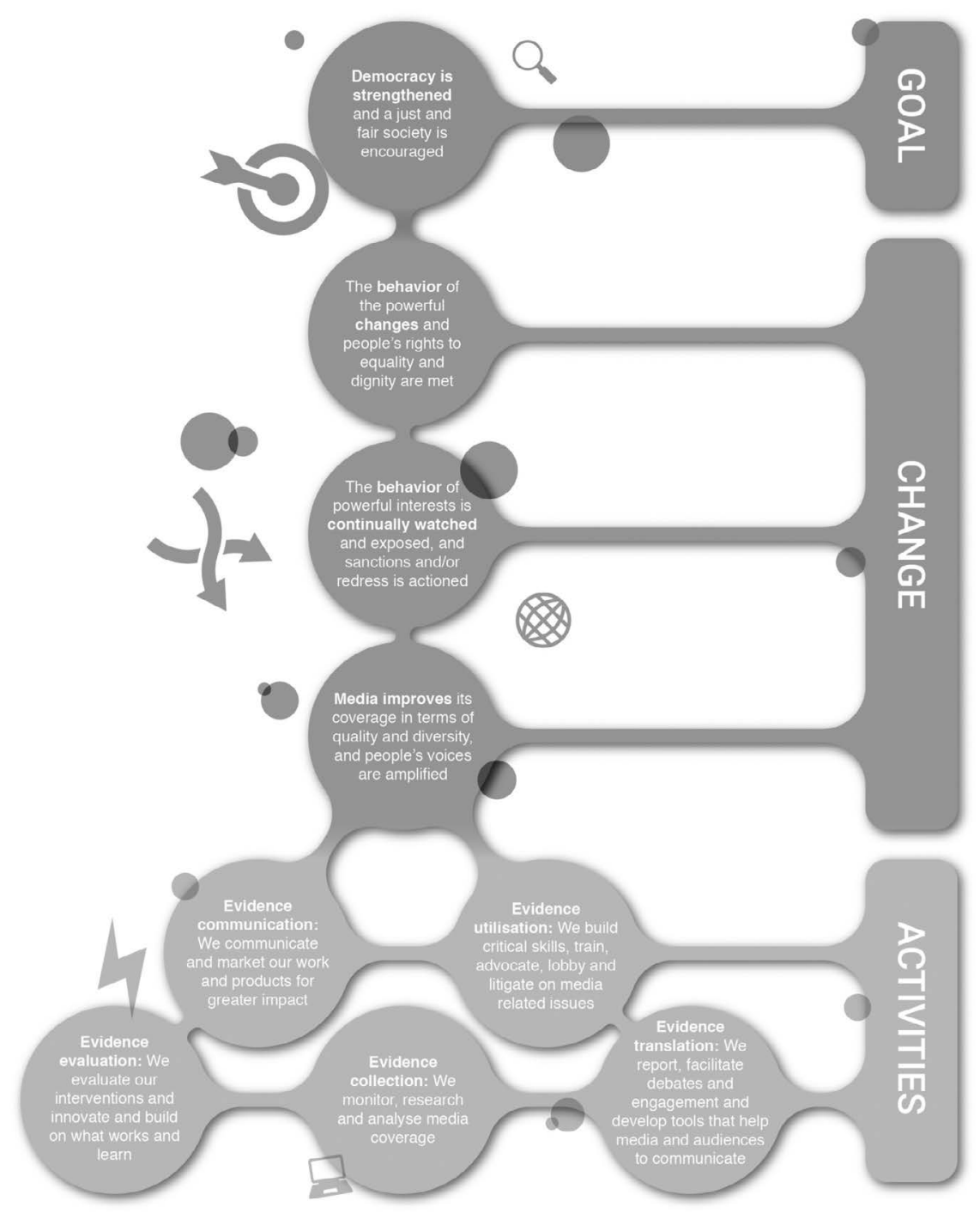

Figure 9.1 MMA's “Theory of Change” infographic. Source: Courtesy of MMA (2018). 


\section{Giuliana Sorce}

still there doing the activism, but it's just that the language you've chosen to use is, I guess, less threatening to some, like the publishers, or government." This echoes Geertsema's (2010) findings on the constraints of gender activism and overall backlash that NGOs experience in South Africa's patriarchal culture.

\section{Theoretical Reflections and Concluding Thoughts}

Taking the activity of a successful South African media activism NGO MMA as a launching point, this chapter develops feminist-democratic media activism as a theory that makes visible the democratic and feminist values inherent to NGO activism in the media sector of the Global South. In building on institutional ethnographic fieldwork, I chart three main values that anchor FDMA as a theoretical lens (see Figure 9.2): Activism as identity and practice, media democratization, and fostering representational equity alongside organizational feminism.

The activist node encompasses both interpersonal and organizational identifications with an activist identity, which can become important for the

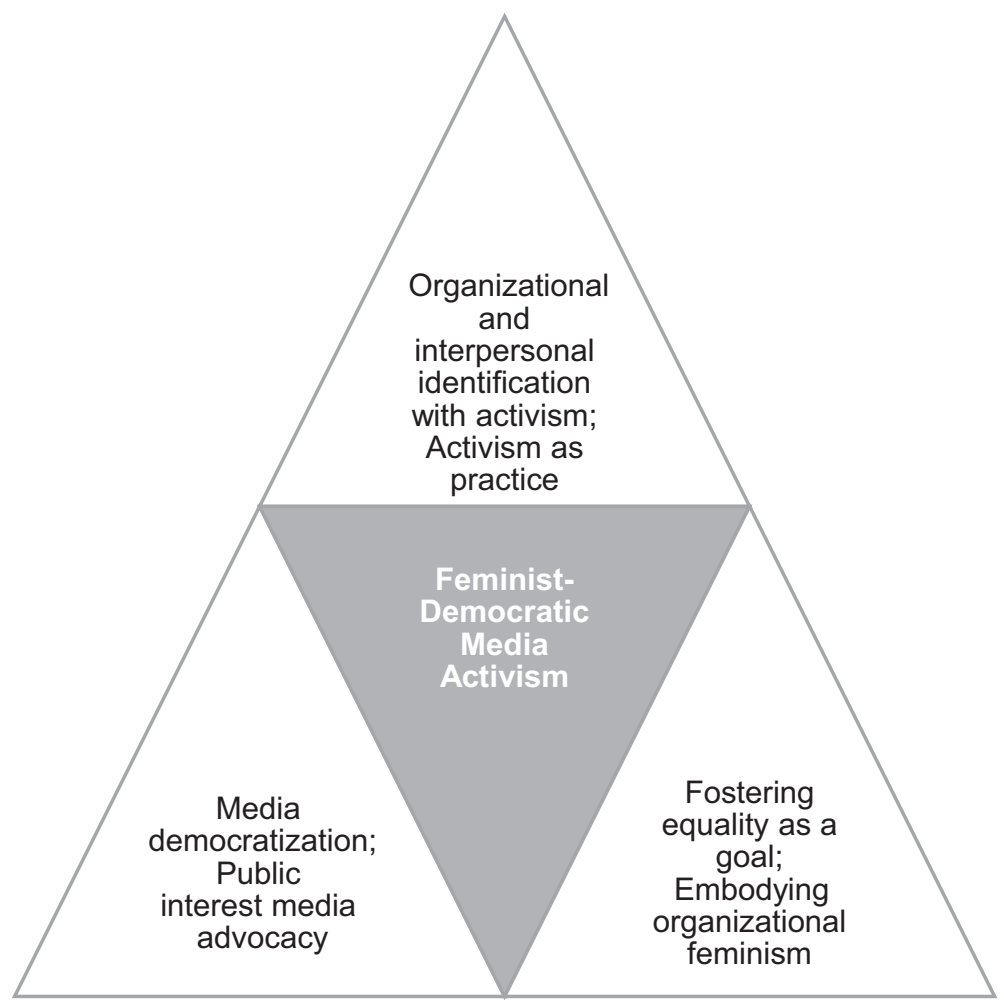

Figure 9.2 The cornerstones of feminist-democratic media activism in NGO contexts. 
formation of a collective identity in the context of NGO work. Further, it implies activism as a form of contentious action that has become integrated into the overall action repertoire of an NGO. The social change agenda of NGOs working on media issues overarches the second node, democracy, which points to efforts of reform and public interest advocacy in the mediascape. Third, the feminist node denotes in how far a media NGO's organizational profile embodies and performs feminist values while explicitly campaigning for intersectional equality.

In building theory from real-life activist practice and experience, FDMA flags three important values of media activism, making them explicit and answering recent call for more nuanced theorizing of media activism (Bennett, 2017). By putting the "feminism" first, FDMA is also in itself a feminist gesture that underscores the importance of feminist-driven NGO activity of social change work. Ultimately, FDMA can thus provide a theoretical backdrop for future studies that assess NGO activist activities, organizing practices, strategies and campaigns, and even impacts on key communities in cross-cultural and multi-sited contexts.

\section{Acknowledgments}

This project was supported by the generous funding of the Arthur W. Page Center for Integrity in Public Communication, the Don Davis Program in Ethical Leadership, and the Africana Research Center at the Pennsylvania State University, USA.

\section{References}

Acker, J. (1990). Hierarchies, jobs, bodies: A theory of gendered organizations. Gender and Society, 4(2), 139-158.

Adelman, M., \& Frey, L. (2001). Untold tales from the field: Living the autoethnographic life in an AIDS residence. In S. Herndon \& G. L. Kreps (Eds.), Qualitative research: Applications in organizational live (pp. 205-226). Cresskill, NJ: Hampton Press.

Banjac, S., \& Dibetso, L. T. (2014). Gender on the agenda: Narratives of masculinity in South African media. Johannesburg: Media Monitoring Africa.

Barassi, V. (2016). Datafied citizens? Social media activism, digital traces and the question about political profiling. Communication and the Public, 1(4), 494-499.

Barnett, C. (1999). The limits of media democratization in South Africa: Politics, privatization and regulation. Media, Culture \& Society, 21, 649-671.

Bennett, W. L. (2017). Foreword: What is media activism? In V. Pickard and G. Yang (Eds.), Media activism in the digital age (pp. xiv-xvi). London: Routledge.

Bosch, T. (2017). Twitter activism and youth in South Africa: The case of \#RhodesMustFall. Information, Communication \& Society, 20(2), 221-232.

Byerly, C. M., \& Ross, K. (2006). Women and media: A critical introduction. Malden: Blackwell. 


\section{Giuliana Sorce}

Calás, M. B., \& Smircich, L. (2006). From the "woman's point of view” ten years later: Towards a feminist organization studies In S. R. Clegg, C. Hardy, T. Lawrence, and W. R. Nord (Eds.), The SAGE handbook of organization studies (pp. 284-346). Thousand Oaks, CA: Sage.

Carroll, W. K., \& Hackett, R. A. (2006). Democratic media activism through the lens of social movement theory. Media, Culture \& Society, 28(1), 83-104.

Chan, M. (2016). Social network sites and political engagement: Exploring the impact of Facebook connections and uses on political protest and participation. Mass Communication and Society, 19(4), 430-451.

Chávez, K. R. (2013). Queer migration politics: Activist rhetoric and coalitional possibilities. Urbana: University of Illinois Press.

Croteau, D. (2005). Which side are you on? The tension between movement scholarship and activism. In D. Croteau, W. Hoynes, \& C. Ryan (Eds.), Rhyming hope and history: Activists, academics, and social movement scholarship (pp. 20-40). Minneapolis: University of Minnesota.

Dibetso, L. T. (2013). Visible invisibility: Gender discrimination in South African media workplaces. Johannesburg: Media Monitoring Africa.

Ferree, M. M., \& Martin, P. Y. (1995). Feminist organizations: Harvest of the new women's movement. Philadelphia, PA: Temple University Press.

Fisher, W. F. (1997). Doing good? The politics and antipolitics of NGO practices. Annual Review of Anthropology, 26, 439-464.

Frey, L. R., \& Carragee, K. M. (Eds.). (2007). Communication activism. Cresskill, NJ: Hampton.

Furnham, A., \& Spencer-Bowdage, S. (2002). Sex role stereotyping in television and advertisements. Communications, 27, 457-483.

Gallagher. M. (2001). Gender setting: New agendas for media monitoring and advocacy. London: Zed Books.

Geertsema, M. (2008, June). Women making news: Gender and media in South Africa. Global Media Journal, 7(12), n. pag.

Geertsema, M. (2009). Women and news: Making connections between the global and the local. Feminist Media Studies, 9(2), 149-172.

Geertsema, M. (2010). Challenging the lion in its den: Dilemmas of gender and media activism in South Africa. Ecquid Novi: African Journalism Studies, 31(1), 68-88.

Hackett, R. A. \& Carroll, R. A., (2006) Remaking media: The struggle to democratize public communication. New York, NY: Routledge.

Hadland, A. (2012). Africanizing three models of media and politics. In D. C. Hallin and P. Mancini (Eds.), Comparing media systems beyond the Western world (pp. 96-118). New York, NY: Cambridge University Press.

Harding, N., Ford, J., \& Fotaki, M. (2013). Is the 'f'-word still dirty? A past, present and future of/for feminist and gender studies in organization. Organization, 20(1), 51-65.

Healy, G., Bradley, H., \& Forson, C. (2011). Intersectional sensibilities in analysing inequality regimes in public sector organizations. Gender, Work \& Organization, 18(5), 467-487.

Hoynes, W. (2005). Media research and media activism. In D. Croteau, W. Hoynes, \& C. Ryan (Eds.), Rhyming hope and history: Activists, academics, and social movement scholarship (pp. 97-114). Minneapolis: University of Minnesota.

Imison, M. (2014). Selling the story: Australian international development NGOs and health news from the developing world. Journalism Practice, 8(4), 438-453. 
Jackson, S. J. (2016). (Re) imagining intersectional democracy from Black feminism to hashtag activism. Women's Studies in Communication, 39(4), 375-379.

Jansen, S., Pooley, J., \& Taub-Pervizpour, L. (Eds.). (2011). Media and social justice. New York, NY: Palgrave Macmillan.

Lewis, D. (1998). Partnership as process: Building an institutional ethnography of an inter-agency aquaculture project in Bangladesh. In D. Mosse, J. Farrington, and A. Rew (Eds.), Development as process: Concepts and methods for working with complexity (pp. 99-114). London: Routledge.

Lewis, D. (2003). NGOs, organizational culture, and institutional sustainability. The Annals of the American Academy of Political and Social Science, 590(1), 212-226.

Louis, W. R., Amiot, C. E., Thomas, E. F., \& Blackwood, L. (2016). The "activist identity" and activism across domains: A multiple identities analysis. Journal of Social Issues, 72(2), 242-263.

Markowitz, L. (2001). Finding the field: Notes on the ethnography of NGOs. Human Organization, 60(1), 40-46.

Milan, S. (2013). Social movements and their technologies: Wiring social change. Basingstoke: Palgrave Macmillan.

Min, S., \& Kim, Y. M. (2012). Choosing the right media for mobilization: Issue advocacy group's media niches in the competitive media environment. Mass Communication and Society, 15(2), 225-244.

Media Monitoring Africa. (n.d.). Theory of change. Retrieved from https://media monitoringafrica.org/our-impact/

Ngai, P. B. Y. (2017). NGO interpretation of participatory communication for rural Cambodia: What is lost in 'translation'? The Journal of International Communication, 23(2), 231-251.

Rodino-Colocino, M. L. (2012). Participant activism: Exploring a methodology for scholar-activists through lessons learned as a precarious labor organizer. Communication, Culture \& Critique 5, 541-562.

Ruelle, O., \& Peverelli, P. (2017). The discursive construction of identity through interaction on social media in a Chinese NGO. Chinese Journal of Communication, 10(1), 12-37.

Smith, D. E. (1974). Women's perspective as a radical critique of sociology. Sociological Inquiry, 44(1), 7-13.

Smith, D. E. (1987). The everyday world as problematic: A feminist sociology. Boston, MA: Northeastern University Press.

Smith, D. E. (2005). Institutional ethnography: A sociology for people. Lanham: AltaMira Press.

Smith, D. E. (2006). Institutional ethnography as practice. Lanham: Rowman \& Littlefield.

Sorce, G. (2019a). Institutional ethnography for communication and media research. The Communication Review, 22(4), 296-308.

Sorce, G. (2019b). Media activism. In D. Merskin (Ed.), The SAGE international encyclopedia of mass media and society (pp. 1032-1033). Thousand Oaks, CA: SAGE.

Sorce, G. (2019c). Weaving into the mediascape: An institutional ethnography of NGO media activism in South Africa. Global Media Journal German Edition, 9(1), 1-28.

Sparks, C. (2009). South African media in transition. Journal of African Media Studies, 1(2), 195-220. 


\section{Giuliana Sorce}

Tarrow, S. (2011). Power in Movement: Social Movements and Contentious Politics (3rd ed.) New York: Cambridge University Press.

Teer-Tomaselli, R. (2015). Broadcasting in southern and eastern Africa. Ecquid Novi: African Journalism Studies, 36(2), 1-4.

Tilly, C. (2006). Regimes and repertoires. Chicago: University of Chicago Press.

Treré, E. (2018). Hybrid media activism: Ecologies, imaginaries, algorithms. London: Routledge.

Vega Montiel, A., \& Macharia, S. (Eds). (2018). Setting the agenda for communication policy: New proposals from the Global Alliance on Media and Gender. Paris: Unesco.

van Zyl, J., \& Kantor, L. (1999). Monitoring the South African media: The shift from apartheid propaganda to the Truth Commission. In Kaarle Nordenstreng and Michael Griffin (Eds.), International media monitoring (pp. 407-426). Creskill, NJ: Hampton Press.

Willems, W. (2015). Alternative mediation, power and civic agency in Africa. In Chris Atton (Ed.), The Routledge companion to alternative and community media (pp. 88-99). New York, NY: Routledge. 


\title{
10 Practicing a Politics of Artistic and Communicative Trans Care
}

\author{
Casa Chama and Transvestigender \\ Rights in Brazil
}

\author{
Isabel Löfgren
}

Transgender, transsexual, transvestite, nonbinary, and gender fluid-or transvestigender ${ }^{1}$-individuals in Brazil constitute the most marginalized population in terms of human rights, social policy, and cultural acceptance. In public discourse and media, trans individuals are often portrayed as gender nonconforming and are culturally and politically stigmatized. Casa Chama is a non-governmental organization (hereafter NGO) based in São Paulo, Brazil, that functions as both a shelter and a network for trans individuals. Based in principles of organizational mutual aid (Spade, 2020) and an ethics of care, the "casa" [house] provides a safe working environment and space for cultural events. In embracing a "family" philosophy guided by Casa Chama's motto "quem acolhe é acolhido, quem é acolhido acolhe" (those who care are cared for, those who are taken care of, provide care) (Casa Chama, 2021), the NGO connects social change networks and provides a platform to amplify trans voices and promote political participation.

Casa Chama's work includes legal aid, for cases such as domestic imprisonment, unwanted conversion therapy, institutional violence by police and hospitals, or financial and hiring discrimination. The NGO also provides psychological support for all trans persons. In addition, it has helped trans individuals with supervised hormone treatments, gender rectification procedures, and trans-specific health monitoring. Thus, the NGO understands itself as doing "survival work" (Spade, 2020, p. 14) for the trans community of São Paulo, with a communicative practice that reaches the entire country. In playing a key role in the trans rights movement, I understand Casa Chama as an autonomous zone of resistance that operates to demand a space for trans individuals in Brazilian culture and politics by practicing trans care. Here, trans care is defined as a politics of care where transvestigender persons' basic needs and connections to fellow citizens are at the forefront. Caring is a democratic act, considering what is given, received, and created together.

Casa Chama's NGO communication repertoire includes in-house art, cultural production, and social media initiatives. It employs both emancipatory and confrontational activist practices as well as dialogic advocacy practices. The NGO's communication ecosystem is integral to trans artivism.

DOI: $10.4324 / 9781003188636-13$ 
It promotes knowledge about trans rights to stakeholders, allied social justice, transvestigender collectives in Brazil, and the general public in order to strengthen marginalized trans voices and lives. Media space is used to facilitate their mission but also occupies media spaces to drive trans rights discourse .

This chapter illuminates how Casa Chama builds community, practices activism, and creates a unique archive of trans history and memory in Brazil through communication and social media practices. It draws on interviews with the organization's key members, combined with a textual analysis of Casa Chama's social media platforms. This method highlights the value of a trans perspective to NGO communication as well as how NGOs can benefit from transvestigendering their organizational structures. As a long-term supporter, collaborator, and organizational ally, my goal was to write with the NGO to adequately reflect their efforts to academic readers (Jeppesen \& Sartoretto, 2020). I engage with trans theorist Dean Spade's (2020) to understand how Casa Chama practices a politics of artistic and communicative trans care within the NGO framework of mutual aid. I then showcase how participatory media production and a "voice of care" (Carse, 1991) can facilitate social change interventions beyond transvestigender rights activism. This can be relevant for any human rights advocacy and NGOs that use similar approaches to survival work, solidarity and community-building, and an ever-expanding commitment to justice that emerges from contact with the complex realities of injustice (Spade, 2020, p. 13).

\section{Background of the Organization}

Casa Chama was formed in the wake of Jair Bolsonaro's presidential electoral campaign in late 2018 as a grassroots political mobilization by a transvestigender artist's collective of the same name, in direct response to the rise of extreme-right campaigning against trans and nonnormative bodies and assumptions against "gender ideology" (Löfgren, 2019). The escalation of hate crime and disdain for organizations working with trans populations was felt immediately by the rapid and historic rise of transphobic crime, alarming statistics of transphobic crime, and structural discrimination in Brazil. Brazil has the world's highest rates of femicide and homophobic/ transphobic crimes in the world, with a murder rate of $82 \%$ among the trans population, out of which $10 \%$ have been attributed to political motivations since 2018. Life expectancy among the trans population is 35 years compared to the Brazilian national average of 75 years (Benevides \& Nogueira, 2019). This signals the urgency for organizations working for social change to support transvestigender individuals who suffer the consequences of transphobia, racism, violence, and poverty. This type of NGO also fills a historical lack in the public sector (da Silva Dantas, 2016) by making political demands for human rights and reparations, creating mechanisms for the autonomy of trans bodies, and gaining agency and voice (Couldry, 2010). 
In 2017, Casa Chama started as an independent arts initiative by transgender and queer artists Rodrigo Franco and Cinthia Marcelle, alongside several transvestigender artists, to expand trans visibility. In a residential house in São Paulo, the artists had access to studios, coworking spaces, an art library, a shared kitchen, and temporary housing acting as a support structure. As artists became increasingly affected by transphobic speech and violence in 2018, they began to articulate the need for a support structure beyond creative professional advice. Franco and Marcelle, along with Casa Chama members, began mapping the needs and demands of transvestigender individuals by mobilizing several LGBTQIA+ networks scattered in São Paulo through WhatsApp groups (Franco et. al., 2020). This resulted in creative collaborations such as the creation of pro-LGBTQIA+ protest material, meetings and reading groups for organizing and building resistance, crowdfunding donations for food and shelter for trans individuals, and more. Community-building was achieved by booking sessions with allied psychologists, arranging legal and medical counsel for safe gender rectification and medical treatments, and creating networks of allies, professionals, and collaborators to provide shelter. This has laid the foundation for what the NGO is today.

A transvestigender artist or trans person cannot exist without being fully recognized in society, which includes legitimizing their true selves in legal and civil terms. Without proper identification, for instance, transvestigender persons may not be able to seek proper recourse in public services and hospitals. Without access to basic health care and safe environments, they have little chance of surviving the violent political climate in Brazil. Casa Chama with a network of professionals ensures that bureaucratic processes are followed and that members are not discriminated against at an institutional level.

In 2019, Casa Chama rapidly expanded its realm of cultural work into wider psycho-social, medical, and legal actions in São Paulo through local services, and with national reach through its communicative actions. The NGO organized the First Chama Festival, a landmark event for radical trans cultural and discursive expressions, featuring trans artists and performers exclusively. During this period, it also expanded its activities to assist more than 100 transvestigender individuals through its network, articulated through the organization's WhatsApp groups and mediated publicly through its Instagram profile. This resulted in more organized and systematic communication with stakeholders and a more robust internal organization designed to attend to their needs.

In 2020, the organization has solidified a range of support structures of care, established its headquarters, and created new forms for managing partnerships, leading projects, and raising funds. This includes a wellarticulated communications nucleus, improved infrastructure, as well as a more established network of allied health and legal professionals and international collaborators. The COVID-19 pandemic revealed 


\section{Isabel Löfgren}

sharp structural inequalities in society which affected trans populations dramatically, thrown instantly into homelessness, lack of income, and hunger. This has trebled the demand for the type of care and assistance provided by Casa Chama's networks and allies, which was largely facilitated by direct actions, outreach campaigns, and donations through social media. This intense period also allowed the NGO to gather significant data about trans communities which is scattered or nonexistent (Chiam et. al., 2020; Fedorko et. al., 2020; Machado, 2020), providing a more evidence-based foundation for its growth as a reference organization in the field.

Casa Chama formally became a registered NGO in August 2020 and regularly assists 200 affiliated members, and up to approximately 800 trans persons who have benefited directly from temporary outreach campaigns and programs to date. The NGO maintains several WhatsApp groups with different groups of stakeholders and also maintains an active social media profile, mainly Instagram, which is the main discursive platform for its multifaceted communications strategy. The profile combines its outreach activities, promotes trans discourses, and creates an archive of trans memory by hosting a series of "live" talks. I contend that this media space is resignified by the NGO from an autonomous zone of resistance to an autonomous zone of trans re-existence and reflects the need to create counter-publics through media activism (Custódio, 2017) from an intersectional trans perspective. Furthermore, through its capacity to produce and broadcast content, the NGO increasingly finds ways to reach new publics and find new alliances to influence public policies. This particular type of content production allows us to examine the type of approach and language used in a specific communication strategy and how it embodies the organization's philosophy of trans care.

I have created the term autonomous zone of resistance inspired by Hakim Bey's (1991) “temporary autonomous zones" (TAZ) to describe Casa Chama's collected actions and philosophy. According to Bey, "a TAZ is a deliberately short-lived (or else precarious) spatial zone in which peak experiences and altered consciousness are realized, in a context of 'autonomy' or the absence of hierarchy" (Bey, 1991). It suggests that a collapse of centralized control will lead to a proliferation of experimental communities and zones that can only be experienced when enacted, where it must be possible to conceive of everyday life in a liberated zone. Casa Chama creates such a liberated zone for the trans community that incorporates a political dimension of opposition and resilience, which transforms the NGO into an autonomous zone of (trans) re-existence (a play of words with the Portuguese word "resistência" [resistance] and the neologism "rexistência" [re-existence]. This term emerged in dialogue with the organization's key members in the interviews conducted for this case study from the understanding that resistance for trans communities is doing opposition and using it as an affirmation of existence and survival. 


\section{Casa Chama as an Artistic-Activist Practice of Trans Care}

Casa Chama's mission is to offer the hospitality of a home as a protected space, a place of belonging and care. This more intimate definition for the trans community is also the foundation for enabling a platform for claiming the struggles of the community and creating new forms of trans politics. Considered an "open family" culture, built on providing mutual care, it emancipates members from difficult living conditions toward a fully recognized trans existence. Co-founder Ana Matheus Abadde describes it as detached from "a patriarchal, paternalist structure where someone is doing something for you" by creating "a space where we do things with and for each other" in a promotional video (Casa Chama, 2019). It is a reciprocal relationship and mutuality between those who provide a structure of care, and those who receive care.

For Casa Chama, practicing trans care translates into dignity, empowerment, and an affirmation of trans existence, in such a way that each part assumes an affective and ethical responsibility before the other (Löfgren, 2020). It does not refer to its stakeholders as clients, nor does it position the support structures it has created and uphold as services as in typical models of corporate governance. Rather, all trans persons that come to Casa Chama for support are considered as "assisted" or "aided" through the NGO's "actions," with the understanding that they also give back to the organization and continuously expand its forms of mutual trans care. In the Brazilian context, this positioning is also a critique of the welfare government strategies termed "social assistance" and fills a historical lack of care for trans populations specifically. After the Brazilian dictatorship (19641985), programs of "social assistance" were conceived as a strategy against the scenario of inequality and denial of rights of a large majority of the population, in part generated by the contradictions of the capitalist system (da Silva Dantas, 2016). This political directive, however, originates in mainstream models of philanthropy consisting of top-down structures managed by people who are not part of the communities they serve, and who often decide who gets help and on what terms, thus replicating societal structures of inequality within government programs (Spade, 2020, p. 23). With the increase of privatization of public social services in recent years, this politics of welfare has left gaps that are then filled by civil society organizations and NGOs, many of which may not necessarily be community-based or generated by social movements themselves-some of them may even have vested corporate interests (Spade, 2020, p. 24).

Casa Chama is an example of NGOs that resist this neoliberal thrust in opposition to the "charity model" and its current iterations in the nonprofit sector (Spade, 2020, p. 28). Kropotkin's notion of mutual aid (1902) that has evolved into contemporary iterations of mutual aid described by Dean Spade (2020) contradicts these "charity models" by allowing the practice of meeting each other's needs based on "shared commitments to dignity, care, 


\section{Isabel Löfgren}

and injustice and allows for practicing coordinated actions with the belief that members of a community are best suited to address the crises they face" (Spade, 2020, p. 16). Casa Chama shares common features associated within this framework: typically member-based, nonhierarchical, and essentially egalitarian, and supportive of participatory processes, shared leadership, and consensus-based decision-making. Furthermore, in this framework, NGOs work toward cultivating notions of justice and liberation in all aspects of life with the community as a point of departure, and not only as a single cause (Spade, 2020). The NGO caters to the needs and demands of trans communities of which it is a part, while rooting its activities in intersectional and queer perspectives shared across LGBTQIA+ movements.

From an art theoretical perspective, self-organizing through-and as extensions from-artistic practices are part of ongoing discourses such as the "social turn" (Bishop, 2006) or the "hospitable turn" (Löfgren, 2020). Many artistic practices in recent decades have emerged in the form of collectives that are embedded in broader social justice movements (Bishop, 2006), where Casa Chama is one example. These practices have clear participatory and community-based strategies, either in generating art together or engaging in larger societal struggles through cultural production. With these notions in mind, Franco emphasizes this resignification of artistic practice as a political practice, stating that "we can only be artistic; because what we are and how we act requires a freedom and courage which can only be attained through this artistic outlook on the conditions we are living in." This does not mean that trans issues are reduced to mere aestheticization, but rather that the aesthetic dimension is a driving force of political action, in this case as a crucial strategy for the autonomy of trans bodies through its organizational structure and its communicative voice.

\section{Transvestigendering NGO Structures and Management}

In previous studies of queer approaches to organizational management, the term "queer" is often referred to as a theoretical perspective that may be used by organizations to diversify their activities by including LGBTQIA+ individuals in organizations (Souza, 2017). However, this does not always mean that a queer perspective changes the organizational culture itself. Some studies highlight the production and extraction of "queer value" for commercial gains (David, 2015), but more scholarship is needed to understand how "queer" or "trans" managers and leaders enable innovative management styles (Souza, 2017). Which aspects characterize trans-driven management in a trans organization, and why are these essential for an NGO like Casa Chama to drive social change?

As transvestigender persons hold key positions, this fundamentally influences the NGO's management style and organizational processes. Leading an organization for transgender rights is not an easy task: It relies on the continued effort and time of volunteers, and constantly working toward 
establishing a community of partnering institutions, webs of collective solidarity, and financial support from a variety of sources. During the interviews, Franco frequently advocated for a common shared construction within Casa Chama, where knowledge, resources, access, and time are shared and redistributed nonhierarchically.

On the executive level, horizontality is practiced by connecting an insider's perspective. In response to whether there is a specific transvestigender style of NGO management, Franco states:

Being trans permeates all organizational processes, from the elaboration of project proposals, to their execution and results. Internally, we aim to be horizontal in all aspects, where hierarchies are dissolved in favor of equal voices for all in key positions-even taking into account the varying level of privileges within the group. Our experience as transvestigender is key for ensuring our dignity and integrity as an organization, our activities, collaborators and those who we assist.

Recruitment for key positions does not rely on typical hiring criteria such as previous experience or academic qualifications but rather on personal experience, the intensity of participation in trans mobilizations, and alignment with the NGO's core values. Many of the core areas are headed by a group of co-founders and a large network of allies.

On a strategic level, trans management also involves identifying new target groups within the transgender community. For instance, finding new ways to give voice to trans men who are a far less visible group in the trans movement given that trans women and transvestites have a historically high media and cultural exposure, both in terms of statistics and in terms of visibility in popular culture. As such, Casa Chama intends to provide specific services and advocacy for this target group that is very much affected by high suicide rates (TransGender Europe, 2020) and whose narratives and needs may often go unnoticed in broader trans discourses.

On an operational level, a trans perspective includes fighting transphobia and trans discrimination within working processes and when interfacing with society-at-large, such as choosing project collaborators, strategic partners, or service providers. When submitting a project proposal to funders or clients, for example, the NGO makes sure that the project leadership teams and production crews harness the talents of members to better serve the interests of the community. Furthermore, the guiding rationale is to do a thorough collective intersectional (race, class, age, disability, and gender) analysis of every project, problem, and idea presented. The choice of strategic partners, the level of agency of participating members, how to deal with conflict resolution, and defining aspects of self-representation in media and communications are taken into careful consideration. Furthermore, choosing project collaborators and partners within the LGBTQIA+ community needs to be thought out, as organizations led by cisgender persons, for instance, may consciously or unconsciously disregard deeper 
aspects that are important to transvestigender persons. When choosing commercial service providers, for instance, one needs to be cautious of those who may require that Casa Chama members declare their legal birth names, instead of the assigned "social name" used after legal gender rectification-something which may lead to a snowball effect of further discrimination, which co-founder Leona Jhovs calls "everyday transphobias" during an interview. Nonetheless, the network of pro bono specialized collaborators in legal, psychological, and voice-training services is expanding, especially among young practitioners who are more attuned to contemporary social struggles or who may themselves be part of them, as well as a diversity of funding partners, donors, and allies.

Casa Chama relies on a combination of project-based funding from public and private sources, international funders such as the International Trans Fund (where, for instance, a trans management is one of the main evaluation criteria), and crowdfunding campaigns for individual donors as well as in-kind donations from a variety of partner institutions. It has an internal committee writing applications for funding, and together with allies in the financial sector, the NGO envisions the creation of an endowment fund that will make the organization sustainable in the long term. Their communication channels play a key aspect in funding, whereby regular posts about crowdfunding are intermingled with other content. However, Franco remarks during interviews that there are concerns regarding funding structures-often the fees are prohibitive for organizations and their stakeholders. This presents opportunities to develop new funding and organizational mechanisms that are more aligned with the needs and possibilities for this type of NGO so that more equality can be achieved between organizations.

Casa Chama is also active in mobilize initiatives to strengthen the NGO community. Co-founder Matuzza Sankofa is also collectively building REBRACA (Brazilian Network of Shelters), which maintains a close relationship with those responsible for trans shelters in Brazil, and as such increase the reach of Casa Chama's approach and organizational philosophy at a national level. For this type of NGO, governance means being self-reliant and knowing how to harness collective resources by protecting each other and coming together in coalitions for bigger mobilizations where knowledge, support, and solidarity are networked and shared. During an interview, Franco summarizes the NGO's rationale:

We have high quality standards, but moreso, we have a high dignity standard in our organization. We rely on our dignity as LGBTQIA+ and transvestigender citizens to push our politics and our actions further. Because if we don't do it, who will do it for us?

\section{Trans Care as a Communicative Practice}

How does Casa Chama's communication strategies mediate and embody its politics of artistic trans care and social change as a communicative practice? There is a considerable body of scholarship regarding minority community 
communication in Latin America showing that community-based media is a collective endeavor in meaning-making, with goals and practices that conjoin physical meetings with electronic participation. Casa Chama is aligned with practices of community-based alternative media as defined by Cicilia Peruzzo (Bona \& Carvalho, 2016), which have a collective history and purpose, are continuous through time, and have public responsibility. Social movements have made significant advances by creating their own media forms and channels to amplify their means of expression and reach. In this context, the use of social media platforms is a given, and more expressive NGOs often professionalize these media practices and train their members in using platforms competently (Bona \& Carvalho, 2016). At Casa Chama, this process of professionalization is attained by constant practice rather than hiring experts from outside the trans community.

The NGO's communications division is a meta-structure shared by many members of the staff who all have media and cultural competency in content creation as they are trained actors, writers, and performers and are engaged in academic and social discourses about trans existence. A social media community manager coordinates the graphic profile and manages interactions. Together with content creators, he prepares a weekly timetable of posts that respond to the organization's actions and campaigns, broadcasts live-streamed contents, and reposts relevant content. It is ensured that trans voices are strengthened throughout. Also, communicative strategies are constantly redefined through interaction and experiences in constant iteration with its public, and not solely determined by the organization leaders. This type of organizational becoming is best exemplified by how Casa Chama exercises its ethics of trans care in every communicative endeavor, further strengthening the notion of an autonomous zone of re-existence.

While the bilingual (Portuguese/English) website (Casa Chama, 2019) is important for institutional purposes, Casa Chama uses mainly Instagram and WhatsApp for community mobilization and consciousness-building. As nearly all staff members have some kind of media training, the type of presentation, modes of address, and artistic content posted displays high professional quality and a strong graphic profile. Despite the lack of significant investment in paid posts and operating with modest production budgets, the account is growing increasingly in popularity, and Casa Chama is known as an important trans media content producer besides its outreach activities and direct actions in the trans community. In an interview, Lyam S., Casa Chama's community manager, reports that $50 \%$ of Instagram followers come from São Paulo, with the remaining audience from all over Brazil and Brazilians abroad. This confirms its social media presence as an aggregator for trans communities at national and international levels.

As a highly visual platform, Instagram presents a range of opportunities that conjoin broadcasting, institutional communication, and artistic expression. The Instagram profile @ casachama_org (Casa Chama 2020) is the NGO's most active channel with 626 posts since January 2019 and 11,400 
followers, followed by the Facebook page with 1,900 likes and 2,200 followers (used mainly for events and cross-posting content from Instagram). The NGO also has a YouTube channel with videos mainly connected to the yearly Casa Chama Festival, but is yet underexplored by the NGO that favors Instagram for broadcasting livestreamed events and other moving image content. There are also collaborations with independent journalism sites and alternative media outlets, especially for livestreamed events, including talks, panels, and interviews.

WhatsApp groups in Brazil are very common and have become one of the main forms of communication and outreach, where approximately $93 \%$ of mobile Internet users use the app everyday (Navarro, 2020). They have become a useful tool for social movement organizers and NGOs to build more structured groups and provide proactive mobilization tools that can be used reliably and in low-resource settings that sustain stakeholder engagement (Jeppesen et al., 2014). Casa Chama runs two public WhatsApp groups, and three other groups focused on the organization itself.

In one of the public groups, as a guest user I have observed that posts vary widely between official announcements and cross-postings from Instagram, interwoven with job postings, invitations for events, calls for project proposals, sharing of news links and videos, as well as instant communication between members. The tonality of the posts is personable, warm, and supportive, while still conveying insitutional messages pragmatically and objectively. More importantly, in this group's description, one can find the contact information for Casa Chama's staff in case they need assistance with medical, legal, or psychosocial appointments, for making donations, and liaising with management and social media managers. This information is otherwise not published on other mediums such as the website for security and digital privacy reasons. In fact, this type of remote assistance has become one of the most common ways for Casa Chama to mobilize their services, responding to individual needs and the history of each individual.

Most of the remote assistance work is done through mobile phones and requires a fair amount of affective labor, as well as often working in vulnerable circumstances with unstable Internet connections or pick-pockets on-the-go, a common occurrence in big cities like São Paulo. The feeds with tens of daily posts include a practice of care in the form of mutual support, as participants often ask for moral or even financial support for incidental issues like mobile phone theft or help with personal matters. The group acts as a space of mediation for the community beyond the NGO itself, following a set of community rules, and as such the groups facilitate community-building and increases their mobilization power in the long run. In the second public group, created during the COVID-19 pandemic to accommodate the urgent demands of a trans community in need, the dynamic is similar, but it is more focused on temporary actions rather than in more long-term activities of the NGO. The internal groups, which I also have access to, are more focused on internal operations and subcommittees to resolve organizational issues. 


\section{“Chama na Live”: Activating Trans Memory, Visibility, and Representation online}

While the WhatsApp groups have a more direct operational function providing direct daily communication with stakeholders, Instagram allows for another kind of networked and situated performativity for the mediation of online trans care. Its goal is to be Casa Chama's "voice of care" (Carse, 1991) for a wider public, and is especially important for resignifying the $\mathrm{NGO}$ as an autonomous zone of trans re-existence. Visibility is indeed a very important aspect of Casa Chama's work, as co-founder Cinthia Marcelle explains: "If society does not recognize [trans] bodies as legitimate, [trans] bodies are able to recognize each other through art; and it's important to consider how big this space can be" (Casa Chama, 2019).

The profile @casachama_org is rich in multimedia content and combines both collaborative and confrontational tactics. It includes announcements for outreach campaigns, campaign videos and posts, posts about campaigns by partner organizations, candid photos of trans persons signing papers for gender rectification, photos taken in the NGO's headquarters, and event announcements. These appear intertwined with a curated series of live interview sessions and talks called "Chama na Live" (or "Chama Live"). These live interview sessions between a program host and a guest are produced in-house by Casa Chama staff, and mostly organized thematically according to the organization's key areas of activity. They represent a dialogic mode of live online interaction between two people that has grown in popularity in Brazil, especially because of the restraints on public cultural activity due to the 2020 COVID-19 pandemic. Live sessions on Instagram and other social media platforms (prolifically used by cultural practitioners, NGOs, and independent journalism sites in panel and open conversation formats) have increased Casa Chama's followers fourfold. Since late 2019, the NGO has hosted 67 "Chama na Live" sessions, which positions it as a vibrant media production house with a strong media activist orientation.

"Chama na Live" consists of a series of weekly live interviews hosted by Leona Jhovs, Digg Franco, and other Casa Chama members. The streamed live broadcasts are conducted by one or two presenter-interviewers in a onehour-long interview-conversation with a member of the trans community, a celebrity or politician involved with trans rights, or with allies and professionals who belong to the NGO's network of supporters. The themes cover a wide range, including trans childhood and parenthood, trans politics, safe sex, cultural politics, aging as a trans person (especially in a population with such a low survival rate), hormone transition, and more. It invites participation through interactions via comments, where viewers are invited to ask questions. Here, the main target group and beneficiaries are the trans communities themselves, but they are equally inviting for a diverse audience. Most "Chama na Live" are streamed on Instagram, and sessions made in collaboration with partners on independent journalism sites or partner organizations are also reposted on Casa Chama's profile. After the municipal 
elections of 2020, for example, Digg Franco and Matuzza Sankofa initiated a series of live interviews with all elected trans politicians in Brazil together with the independent news site Jornalistas Livres, thus expanding the reach to new audiences. This is an example of a communicative action aimed at increasing consciousness and mobilization of trans politicians in society, and part of the NGO's political strategy for increased representation in decisionand policy-making.

"Chama na Live" are first announced via a graphic callout a few days before the broadcast, and recorded sessions are posted on the feed a few days later, thus forming an audiovisual archive of these conversations. When we look at the Instagram feed with the archive of recordings, it takes on the function of an extensive curated oral archive of trans history and activism. As such, it becomes a unique medium for building trans memory, enabling the construction of a unique historical archive of trans histories (Hoskins, 2018) with instant access and wide circulation. As program hostess Leona Jhovs articulates in an interview, "even while our memories are constantly being erased when they kill us, our aim is to memorialize these trans life stories through the live sessions." Here, I see that the archive produced by this communicative action contributes to the broadening of the possibility of the online "musealization" of trans experiences (Hoskins, 2018). The urgency in creating a trans media presence by transvestigender persons and for a transvestigender public is also done in opposition to the hegemonic mediatization of trans bodies and narratives in mainstream outlets. In Brazil, transvestigender bodies are often portrayed as deviant or criminal, or else as caricatures, devoid of humanity, agency, and subjectivity. It also shows that social media are places of memory within movements of resistance and social justice, and not merely as communication tools that fulfill an NGO's practical goals concerning donors or funders, as is the case of much NGO communication.

Approaching social media as a space for historicizing and promoting respect for human rights and trans diversity can also be framed within the organization's philosophy of trans care if we examine the dialogic conversation/interview format more closely. This rather intimate format invites interactions that make trans bodies visible and "speechable" beyond the traditional paradigm of one-way broadcast communication. The creation of this online oral archive harnesses the opportunities that online platforms avail to call out injustices and show the world that organizations like Casa Chama exist. It also helps in demystifying the notion of disposable speechless subaltern trans bodies into bodies that actively speak (Spivak, 2010) and produce knowledge and discourses on their terms. As Afro-German artist and theorist Grada Kilomba reminds us, "One can (only) speak when one's voice is listened to. Within this dialect, those who are listened to are those who 'belong'" (Kilomba, 2008, pp. 21-22). As such, online media spaces may be able to foster a high degree of belonging, of finding a home (a "casa") for trans voices to be listened to, whereby the social media platform constitutes a place of refuge for trans audiences. 
Furthermore, social media platforms can be an important agent for resignifying transgender history that is equally available to the trans community as well as wider audiences. Because the assumed audience are people like themselves, the modes of address thus cut through a need to overturn heteronormative discourses. It takes on a more self-affirmative mode of address, typical of being in a "safe space," even though the awareness of being watched by non-trans people is always there. The type of utterance and language used therefore invites non-trans audiences to also take part in trans narratives in the terms set forth by the community itself in such a way that affirms certain vocabularies and positionalities that trans audiences can fully relate to. Thus, the heteronorm of "us" (non-trans) looking at "them" (trans) is dissolved (Horak, 2014).

However, there is a paradox of visibility in social media as a place of refuge and trans care. While the live sessions provide a safe space and result in a unique archive of trans history, they are equally open to anyone to view, comment, and interact, which may make these spaces vulnerable to counterdiscourses and hate speech. I noticed that sometimes words and ideas are formulated very carefully, which reflects an awareness that trans enunciations may be misunderstood or misappropriated by a public that may act as voyeurs of the conversation instead of solidary participants. As such, while the mode of address by speakers is not exclusionary or opaque, issues of exposure and vulnerability often resurface during the live conversations. When program hosts ask interviewees about the paradox of visibility, the presence of non-trans people is not readily considered a threat or an inhibitor of the conversation. In a live session with actress and YouTuber Gabriela Loran, Jhovs asks:

- Leona Jhovs: How do you deal with your online exposure? Can it be negative for you?

- Gloria Loran: I don't have haters on my [Instagram] profile. But sometimes I feel, from some comments I get, that humanity is not advancing forward. If we reply to these negative comments, we are only fueling this discourse which at the end is not about us, it's about themunhappy people unable to love, unable to feel empathy. I don't potentialize this type of superficial, empty discourse. People are still stuck in XX and XY discourse. This is old news (Jhovs, 2020, August 11).

In response to the same question, Black-Amerindian trans art director Neon Cunha states:

People are bound to attack us on the Internet. In order to achieve a humanization online, we need to state firmly that our bodies are constantly being dehumanized. Our struggles somehow are directed toward non-trans people, who insist on keeping us in a vulnerable place, even though we try to occupy more spaces with our discourses. On the other 
hand, we have gone a long way, there is more dignified visibility, there have been openings where we can practice our trans existence. We are now in a possible place, by us and for us - this is the biggest achievement. ... Our existence makes possible the idea of a more plural humanity for everyone. We are experiencing freedom, we inhabit a possibility of being who we are, which is liberating for everyone.

(Jhovs, 2020, October 2)

Casa Chama has indeed experienced relatively little hate speech or cyberbullying until a phishing attack in early December 2020 suspended the account temporarily. The attack was regarded as an attempt to silence trans voices by the NGO and its stakeholders, with the potential of the unique archive of trans memory being lost . Community Manager Lyam S. quickly responded with a note on Instagram and all WhatsApp groups regarding the cyberattack:

On December 10, 2020, Casa Chama NGO suffered a transphobic cyber attack, in which hackers entered our account and deleted part of our content such as posts regarding information about civil rights of transvestigender populations, information about our actions, and live sessions recorded during the pandemic — content which is political and necessary. We recovered access to our account, but we believe that no transphobic crime will be able to silence us. ... Our voices are built in a network, as a Jota Mombaça says, "they will not kill us just yet." In the process of regaining access to our account, we encountered many initiatives against the spread of hate speech such as \#tretaaqui that maps attacks connected to the elections and the organization AccessNowaccessnow.org which provides information about cyber security and human rights. THEY WILL NOT SILENCE US!

(S., 2020, December 18)

Luckily, with the help of allied experts in cybersecurity, the archive of live sessions was recovered. Loyal to its horizontal structure, many staff members share login information and can post on the accounts, which reflects the notion of a shared communications structure, but it was not until this event that further steps toward achieving cybersecurity were identified. This signals the importance for NGOs to adopt measures that ensure digital security to be able to keep working with media activist strategies. This is especially important because the NGO's communication is largely dependent on social media platforms on the one hand, and trans-activists are targeted by conservative audiences as radical and transgressive on the other. Due to increased surveillance and data collection from platforms through mobile phones and apps, this is something NGOs that are active in communitybuilding for vulnerable populations need to take into account in the future. Even after this experience and awareness of the vulnerability to these kinds 
of attacks, online exposure and a strong engagement through social media are nonetheless beneficial for NGOs, and which Casa Chama will continue to expand on.

\section{Conclusion}

As an autonomous zone of trans re-existence for the promotion of a dignified life, communication is more than instrumental value or part of organizational strategy-it is a form of survival itself. It is an important motor for growth and visibility, especially regarding reaching new audiences and target groups, and more importantly for advocacy and political mobilization. An ethics of care and dignity is what Franco believes to be the essence of longterm sustainability for Casa Chama, which he states is, in the end, "always a political process."

Casa Chama's upscale of activities and communicative actions has happened in a conservative political moment, which has, through social mobilizations, also seen the rise of several transvestigender politicians in elected positions in municipal and state constituencies across the country, in part aided by the trans voices raised against the escalation of violence against trans bodies and discourses. As a response, in November 2020, Casa Chama's co-directors Rodrigo Franco and Matuzza Sankofa started a series of live interviews with 30 elected trans politicians all over the country in partnership with independent media outlets, resulting in an increasingly broad articulation for political representation of trans issues in the public sphere by the members of the trans community itself, confirming what Franco states in an interview: "In politics we began, and in politics we will make the biggest change." This is crucial for trans politics in Brazil to avoid the trans community from being further criminalized, or else have its practices of care being co-opted by authorities in instrumental models of "social assistance" (da Silva Dantas, 2016) away from the community. This would help lead the way toward systems that are less coercive and more based on principles of self-determination (Spade, 2020) with underlying ethics of care as a core value.

Even though much of the communicational activity is happening online since 2020 due to social distancing in the COVID-19 pandemic, this does not mean that Casa Chama will be exclusively reliant on social media platforms in the future. The NGO has traditionally participated in countless seminars, lectures, and forums promoting its values, which has also helped create a language that raises awareness and brings allies to their causes and struggles. Casa Chama intends to use its new office space to reactivate study groups and conversation/reading circles, which were its main forms of community organization and articulation since the very beginning. WhatsApp and social media groups will still be a fundamental cornerstone where the NGO organizes and shares all offered opportunities and where vital content from society-at-large is shared daily. 
In order to maintain a personalized treatment toward those persons assisted, improved forms of organization and communication to handle increasing demands are being put into place. This is a challenge for NGOs like Casa Chama who do not see growth as a move toward centralizing or standardizing services for the sake of effectiveness. In line with trans scholar Dean Spade's toolkit for mutual aid organizations (2020), scaling up means building more and more mutual aid constellations, promoting best practices, and adapting them to different contexts without losing sight of core values. At the moment, Casa Chama is receiving pro bono management consultancy to help it grow. All co-founders and key members are invited to participate in collective visioning sessions, as an example of its horizontal decision-making structure and participatory approach.

By looking at Casa Chama's communicative strategies, we understand that art and media activism should be considered a key aspect of a politics and ethics of care following the NGO's core philosophy. Casa Chama's communication strategies and content production for trans visibility, memory, and political representation can inspire NGOs to learn from these strategies of social change. By moving beyond the paradigm of corporate-oriented NGO communication with "investors" and promoting "services" for "clients," the model of mutual aid can inspire strategies that enhance support structures and agency for the communities NGOs cater to. This entails engaging each community member as agents of social change and providing a platform for the community's voices to be heard, exist, and be amplified in a consistent, ethical, and professional manner. To conclude, Franco states in an interview that "if we succeed in creating a robust support structure, including communications, for the transvestigender population, our model can be certainly applied to other vulnerable groups in society in order to achieve change at a systemic level." By looking at the best practices and learning from the margins with those who are at the forefront of civic action, NGOs like Casa Chama contribute to developing platforms that can be upscaled and applied to other marginalized groups and social movements.

Thanks to Casa Chama for the attention and generosity in sharing valuable information for this chapter, especially Rodrigo Franco, Leona Jhovs and Lyam S.

\section{Note}

1. Transvestigender is a term used by Casa Chama as a way of embracing the different identities of its stakeholders. It was originally coined by Brazilian activist, sex worker, and transvestite politician Indianare Siqueira combining the terms "transvestite" and "transexual" while encapsulating the fluidity of masculinity and femininity as nonbinary. The term has "transgressive power in denouncing the urgent need to reconstruct gendered conceptualizations in practice and in theory, to disrupt the violence caused by binary gendering, and to recognize the power and potentialities of multiple gender identities at a political level" (Puta Observatório Transvestigênere, 2020). 


\section{References}

Benevides, B. G., \& Nogueira, S. N. B. (2019). Dossier: Murders and violence against Travestis and Trans People in Brazil-2018 (S. Wagner York \& J. R. Longaker, Trans.). National Association of Travestis and Transsexuals in Brazil (ANTRA), Brazilian Institute of Trans Education (IBTE), Distrito Drag. Brazil. Retrieved October 12, 2020, from https://antrabrasil.files.wordpress.com/2019/11/murdersand-violence-against-travestis-and-trans-people-in-brazil-2018.pdf

Bey, H. (1991). The Temporary Autonomous Zone. New York: Autonomedia.

Bishop, C. (2006). The Social Turn: Collaboration and Its Discontents. Artforum, 44(6), 178-183. Retrieved October 20, 2020, from https://www.artforum.com/ print/200602/the-social-turn-collaboration-and-ist-discontents-10274

Bona, N., \& Carvalho, G. (2016). Cicilia Peruzzo e as tendências para a pesquisa em comunicação popular e alternativa no Brasil. Revista Uninter de Comunicação, 4(6). http://doi.org/10.21882/ruc.v4i6.633

Carse, A. L. (1991). The 'Voice of Care': Implications for a Bioethical Education. The Journal of Medicine and Philosophy: A Forum for Bioethhics and Philosophy of Medicine, 16(1), pp. 5-28). http://doi.org/10.1093/jmp/16.1.5

Casa Chama (2021). About. Retrieved February 12, 2021, from http://www.casachama.org/en/category/about/

Casa Chama (2019). Sobre Nós-A Casa Chama 2019. Retrieved February 12, 2021, from http://www.casachama.org/en/filme/

Casa Chama (2020). @casachama_org. Instagram. https://www.instagram.com/casa chama_org/?hl=en

Chiam, Z., Duffy, S., González Gil, M., Goodwin, L., \& Mpemba Patel, N. T. (2020). Trans Legal Mapping Report 2019: Recognition Before the Law. Geneva: ILGA World. Retrieved October 20, 2020, from https://ilga.org/ilga-world-releases-translegal-mapping-report-3rd-edition

Couldry, N. (2010). Why Voice Matters: Culture And Politics After Neoliberalism. London: Sage.

Custódio, L. (2017). Favela Media Activism: Counterpublics for Human Rights in Brazil. Boston: Lexington Books.

Da Silva Dantas, J. G. (2016). Social Assitance in Brazil: The Charitable By Law. Socializando, Ano 3(1), 105-113.

David, E. (2015). Purple-Collar Labor: Transgender Workers and Queer Value at Global Call Centers in the Philippines. Gender \& Society, 29(2), 169-194. https:// doi.org/10.1177/0891243214558868

Fedorko, B., Kurmanov, S., \& Berredo, L. (2020). A Brief Guide to Monitoring Anti-Trans Violence. TransGender Europe (TGEU). https://transrespect.org/en/ brief-guide-to-monitoring-anti-trans-violence/

Franco, R., Carolina, L., \& Triani, S. (2020). Nas Tramas da Cultura: Autonomia de Corpos e reducão de danos, uma perspectiva rizomática. Coletivo ChamaRenfa. Retrieved October 12, 2020, from http://issuu.com/jessicarocha6/docs/ boletim_chama_renfa_1_1a51668b67954a

Jeppesen, S., Kruzynski, A., Lakoff, A., \& Sarrasin, R. (2014). Grassroots autonomous media practices: a diversity of tactics. Journal of Media Practice, 15(1), 21-38. https://doi.org/10.1080/14682753.2014.892697

Jeppesen, S. \& Sartoretto, P. (eds.) (2020). Media Activist Research Ethics: Global Approaches to Negotiating Power in Social Justice Research. Palgrave. 


\section{Isabel Löfgren}

Jhovs, L. (2020, August 11). Chama na Live: Leona Jhovs entrevista Gabriela Loran [Instagram post]. Instagram. Retrieved from https://www.instagram.com/p/CDwvojy $\mathrm{HsmC/}$

Jhovs, L. (2020, October 2). Chama na Live: Leona Jhovs entrevista Neon Cunha [Instagram post]. Instagram. Retrieved from https://www.instagram.com/p/CF2w8 DYHmZC/

Horak, L. (2014). Trans on YouTube: Intimacy, Visibility, Temporality. Transgender Studies Quarterly, 1(4), 572-585. https://doi.org/10.1215/23289252-2815255

Hoskins, A. (Ed.). (2018). Digital memory studies: Media pasts in transition. New York: Routledge.

Kilomba, G. (2008). Plantation Memories: Episodes in Everyday Racism. Unrast Verlag.

Kropotkin, P. (1902). Mutual Aid: A Factor of Evolution. Retrieved February 9, 2021, from https://theanarchistlibrary.org/library/petr-kropotkin-mutual-aid-afactor-of-evolution

Löfgren, I. (2019). Fragments of an Ongoing Nightmare: Written from an Atuonomous Zone of resistance in a State of Perplexity. Paletten 316, 23-39. Retrieved October 12, 2020, from https://www.academia.edu/39681921/Fragments_of_ an_Ongoing_Nightmare_Written_from_an_Autonomous_Zone_of_Resistance_ in_a_State_of_Perplexity

Löfgren, I. (2020). Satellite Lifelines: Media, Art, Migration and the Crisis of Hospitality in Divided Cities. Theory on Demand \#38. Amsterdam: Institute of Network Cultures.

Machado, R. (2020). Casas de Acolhida LGBT no Brasil: reflexões museológicas em contexto pandêmico. Revista Memórias LGBT+Feminismo, 7(12), 41-47.

Navarro, J.G. (2020, December 7). Brazil: frequency of Whatsapp use 2020. Statista. Retrieved February 15, 2021, from https://www.statista.com/statistics/1076956/ brazil-frequency-whatsapp-uage/

Puta Observatório Transvestigênere (2020). Retrieved October 21, 2020, from http:// putaobservatoriotransvestigenere.com/

S., L. (2020, December 18). Casa Chama @casachama_org_Ataque Virtual_“"They will not kill us just yet” [Instagram post]. Instagram. https://www.instagram.com/p/ CI7xlOKnAfh/

Souza, EMD. (2017). Where is queer theory in organizational studies?. Sociology International Journal, 1(4), 127-134.

Spade, Dean (2020). Mutual Aid: Building Solidarity Through This Crisis and the Next. London: Verso Books.

Spivak, G. (2010). "Can the Subaltern Speak?": Revised edition, from the "History" chapter of Critique of Postcolonial Reason. In Morris, R. (Ed.), Can the Subaltern Speak?: Reflections on the History of an Idea (pp. 21-78). New York: Columbia University Press. doi:10.7312/morr14384.5

TransGender Europe (TGEU). Trans rights under attack worldwide. (2020, June 15). Retrieved October 8, 2020, from https://tgeu.org/trans-rights-under-attackworldwide/ 


\section{Index}

Page numbers in italics indicate a figure and page numbers in bold indicate a table on the corresponding page. Page numbers followed by ' $n$ ' refer to notes.

$1 \%$ for The Planet Inc. 31, 41-42

350.org 40-41

$360^{\circ}$ videos 93

Abadde, Ana Matheus 183

Abdallah, H. 13

Abdals 110

Acer, Eleanor 64

ActionAid 90

active citizenship 76

activism: data(fied) 160; digital 77; gender-based 162 ; making as practice 167-168, 174; media 4, 160-162, 164-165, 194; see also feministdemocratic media activism (FDMA) activist values, of media NGOs 165 ; activism as practice 167-168, 174; interpersonal identification 167 ; organizational identification 166-167

Adolescent Reproductive Health Education program (BRAC) 92 advertising 82

advocacy 109, 124; abandoning community 139 ; effective 112 ; media 164; at MMA 167-168; public interest media 170; refugee advocacy in US 54; social change in Sudan 4; in Turkey 110

African National Congress (ANC) 169

Aguilera, R. V. 9

Ahmed, S. M. 92

Akar, S. 124

Aksak Ozdora, Emel 4, 109

Alam, Naima 3-4, 90

Al-Beshir, A. 148

Albright, Madeleine 59 alliance legitimacy 16

Al Randok (colloquial Arabic) 153

Amanpour, Christiane 65

Amnesty International 50

analogue communication 80

ANC see African National Congress (ANC)

animated videos 91; see also explainer videos/animations

announcement videos 94, 95, 102

artificial intelligence 41

artistic practices 184

arts-based interventions 4

audience engagement 58-60

audiovisual medium, for NGOs 4

auditory elements 94

Austin, J. E. 20

bag-of-words technique 37-38

balanced-interest strategy 17

Bangladesh 90, 95-96; see also Building Resources Across Communities (BRAC)

Bangladesh Women's Foundation 90

BankTrack 19

Bare, J. 34

bargaining 23

Bashri, Maha 4, 145

Beckmann, M. 111

Beck, U. 112

behind-the-scenes stories 93

Bennett, W. L. 162-163, 164

Besiou, M. 62

Bey, Hakim 182

Bhuiya, A. 92

black liberation 163 
blending, of different channels 79

Blue Planet (Hawaii) 30

Bogert, Carroll 57, 59, 62

Bolsonaro, Jair 180

Boyatzis, R. 55

Boys \& Girls Club 15

BRAC see Building Resources Across Communities (BRAC)

Brand, T. 19

Brazil: Casa Chama 4; marginalized population in 179; public awareness campaigns 3

Britten, N. 115

broadcasting 77

Bruijn, T. 11

Building Resources Across Communities (BRAC) 4, 91-93; during COVID-19 pandemic 97; explainer animations 96-102; Human Rights and Legal Aids Services Centre (HRLS) 97; Keep pregnant and new mothers safe 100-102; Rabeya's right to a happy life, free of abuse 97-100; Shasthya Sebika 92

Burton, S. 24

business-community partnerships 12

Byerly, C. M. 163

Byrd, R. 29

calls to action 79

campaign-specific online presence 84 capacity-building process 32,114 ; for climate change NGOs in US 33-34; in ENGOs 35

carbon dioxide emissions 29

Carroll, W. K. 163

Casa Chama, and transvestigender rights in Brazil 4, 179; as artisticactivist practice of trans care 183-184; background 180-182; Chama na Live 189-193; during COVID-19 pandemic 193; cyberattack 192 ; structures and management 184-186; trans care as communicative practice 186-188

cause-based partnerships 12

CCRM (Cross-Regional Center for Refugees and Migrants) 117

C\&E Corporate-NGO Partnerships Barometer 10

Chadwick, A. 79

Chama na Live 189-193

Chase, L. 23

Chaudhri, Vidhi 3, 9 child labor 110, 117; death in Guangdong, China (2016) 135; development projects 113-114; in Turkey 121-122

China: labor relations in 133; NGOs 20-21, 128-129; parents' education courses for migrant workers 138; see also Inno Community Development Organisation; labor NGOs, in China

Choi, M. 14

Chomsky, N. 65

Chowdhury, A. M. R. 92

clickbait 62

climatic change 9, 29-30

CNP 34

collaborative corporate social responsibility campaigns 3

Collaborative Value Creation (CVC) framework 13

congruence and/or fit alliance 14

Comic Relief 16

communication 2; alternative styles 61, 65-66; analogue 80; of CSR 15; DWC strategies 117-121; NGObusiness partnerships 15-17; offline 80-81; one-way 79; public 52; symmetric 148-149; transparency in NGOs 4, 147; two-way 79, 84, 149; see also dialogue; social media, in NGO strategic communication community-based posts 153,155 community-building 79, 181 community empowerment 30 company-cause fit 14

competence 23

complementary resources 11,12 computational data processing 35 Cordaid 76

corporate-nonprofit partnerships 14-15 corporate social responsibility (CSR) $3,9-10$; communication of 15 ; controversial bill in India 21; institutionalization of 11 ; motives of 14; partnerships 12-13

cost-saving benefits 39

COVID-19 pandemic 32; and BRAC initiatives 97; Casa Chama during 193; Inno's services 141; mobilizing resources 41; needs of trans community during 188 ; structural inequalities in society 181-182

Crabtree, B. 56

crackdown on labor organizers, in China 129, 140 
creating shared value (CSV) 10

Crossing the Line (video series) 61

cross-promotion 79

cross-sector collaborations see NGO-

business partnerships

CSR see corporate social responsibility (CSR)

CSV see creating shared value (CSV)

Cunha, Neon 191-192

Curan, J. P. 63

CVC framework see Collaborative Value Creation (CVC) framework

Dangerous Territory: Mexico Still Not Safe for Refugees 61

data(fied) activism 160

"Decade of the Girl Child" 90, 102

December Revolution 154, 156

Deloitte 22

DeMates, L. 29

democratic media activism (DMA) 163

democratic values, of media NGOs 168 ; media democratization 169-170; public interest media advocacy 170 den Hond, F. 22

developing countries, NGO-business collaborations in 21

development-focused NGOs 109

Development Workshop Cooperative (DWC) 4, 110, 112-114; communication strategies 117-121; development projects with international aid 113-114; findings 116-117; main challenges and recommendations 121-124; method 114-116; mission and experience 116-117

De Vita, C. J. 32

dialogue 1, 3, 18-19, 83, 149

digital activism 77

digital participation initiatives 3

Dimitrova, Daniela V. 109

discursive democracy 52, 53, 53

DMA see democratic media activism (DMA)

do-democracy 76

domestic violence 91, 97

Doms community 110, 118

donations 34,79 ; electronic 38 ; national donation campaigns 76 ; online $34,38,40$

Dong, C. 16

door-to-door solicitations 76

Dow Jones Sustainability Index $24 n 1$
Dumitrica, Delia 3, 4, 73

Dutch NGOs 76-77

DWC see Development Workshop Cooperative (DWC)

Edelman Trust Barometer 22

Einstein, Albert 59

electronic donation 38

email 33, 75

engagement collaboration 20

ENGOs see environmental nongovernment organizations (ENGOs) entertainment education (E-E) videos 91 environmental collaborations, in Nigeria 18-20

Environmental Defense Fund 30 environmental non-government organizations (ENGOs) 29; digital technology applications 34; official websites 33; textual contents of 37; in United States 3, 31

environmental sustainability, in Nigeria 3 EP see Equator Principles (EP)

Equator Principles (EP) 19

Erdoğdu, M. M. 124

Ertan Karabiyık 115-123

ethical behavior 23

ethnography approach 160, 164-165

European Broadcasting Union 62

explainer videos/animations 4, 91; auditory elements 94; narrative strategy 94; for social change campaigns 93-94; visual design 94 external resource environments $83-84$ extracted keywords 40-41

Facebook 4, 15, 40, 79, 82, 84, 145, 150

face-to-face interactions $80,113,136$

FDMA see feminist-democratic media activism (FDMA)

Federatie Broekpolder 80

feminist-democratic media activism (FDMA) 160-161, 165, 174, 174

feminist values, of media NGOs: fostering equality as goal 170-171; organizational feminism 171-174

Fenton, N. 57

Fereday, J. 56

Ferree, M. M. 172

Figenschou, T. U. 60

financial management, comprehensive 32

financial resource mobilization 38 , 39,42 
First Chama Festival 181

Fleming, C. 32

Franceschini, I. 131

Franco, Digg 190

Franco, Rodrigo 181, 184-186, 193-194

Freedom of Expression Institute (FXI) 169

Freire, Paulo 1

FXI see Freedom of Expression Institute (FXI)

Gallagher, M. 162, 164

Gambia 21

Garcia, Andy 59

Garkisch, M. 111

Geertsema, M. 162, 164, 174

gender: inequalities 90-91, 96; issues 128; mainstreaming 164; misrepresentation 162

gender-based activism 162

Ghoshal, Neela 57

Giddens, A. 9

Gillmor, D. 56

Glasbergen, P. 18

Global250 10

Global Forum on Migration and Development 117

Global Media Monitoring Project (GMMP) 162

Global NGO Technology Report 201930

global refugee crisis 50

global warming 29

GMMP see Global Media Monitoring Project (GMMP)

good citizenship 76

good journalism 64

Google News 62

Greenberg, J. 56

Greenpeace 30

Guangzhou (China), University City sanitation workers' strike in 136

Guo, C. 34, 35

Hackett, R. A. 163

Hall, N. 54

Harness, Delaney 3, 49

Hawadith Street Initiative (HSI) 146, 147-148; information 151-153; offline mobilization 154; reaching out to stakeholders 153-154

He, A. J. 130-131

Heatherington, Tim 60

Heidingsfelder, J. 111
Hein, James Everett 3, 9

Helsinki Watch see Human Rights Watch (HRW)

Herman, E. S. 65

HIRI 34

Hivos 76

Honders, H. 11

hospitable turn 184

Hoynes, W. 164, 172

HRF see Human Rights First (HRF)

HRLS see Human Rights and Legal Aids Services Centre (HRLS)

HRW see Human Rights Watch (HRW)

HSI see Hawadith Street Initiative (HSI)

Huang, G. 130-131

human resource mobilization 38, 39, 42

Human Rights and Legal Aids Services Centre (HRLS) 97

Human Rights First (HRF) 50, 53, 59, 65-66

Human Rights Watch (HRW) 50, 53,57 ; and refugee rights 55 ; and Upworthy 61-62, 66; use of digital technologies 61-62

Hunter, M. L. 62

hybrid media systems 75,80

ICASA see Independent Communications Authority of South Africa (ICASA)

ICCO 76

ICTs see information communication technologies (ICTs)

Idemudia, U. 19, 22

Ihlen, Ø. 60, 109, 111

immigration policy 60

Improving the Health and Protection of Vulnerable Syrian and Marginalized Migrant in Southern Turkey Project 113

Independent Communications Authority of South Africa (ICASA) 169

India: CSR Bill (2013) 21; NGOs 131

inequalities, in media 160

information communication technologies (ICTs) 30; capacitybuilding for climate change NGOs in US 33-34; enabled capacity-building framework 34; in ENGOs' capacitybuilding 35 ; policymaking processes and outcomes 42

"Information-Community-Action" framework 146, 148-150 
information provision 79,83

INGOs see International NGOs (INGOs)

Inno Community Development Organisation 4, 129, 132; abandoning community advocacy 139; avoiding conflict with government 134; during COVID-

19 pandemic 141; labor rights case 135; low profile role 141 ; media negotiations 137-138; narrative approaches 132; in Sri Lanka 135; state negotiations 133-136; tightening regulations 129-130; workers negotiations 136-137

Instagram 40, 82, 187, 189-191

institutional ethnography 160, 164-165

integrative partnership 14

International NGOs (INGOs) 2, 109, 124,128

International Trans Fund 186

Internet: network of NGOs on climate change 30; and SNSs 145, 146, 156 issue mobilization 3

Jamali, D. 13

Jhovs, Leona 186, 190-192, 194

JIV training see joint investigation visits (JIV) training

joint investigation visits (JIV) training 11

Jones, P. M. 93

Jonker, J. 11

Jordan, L. 112

Jungian archetypical characters 95

Kang, Yowei 3, 29, 34

Kantor, L. 161

Karim, S. 23

Keck, M. 49, 53, 63

Kelleher, T. 149, 155

Kent, M. L. 149

keyword extraction 37

Khartoum, Sudan 147-148, 154

Kilomba, Grada 190

Kim, N. 14, 16

Knight, G. 56

Knight Foundation 34

Knittel, Christopher 29

Kolk, A. 20

Kropotkin, P. 183

Kunis, Mila 59

Kupe, Tawana 166

Kyoto Protocol 9 labor: disputes 135-136; migration $110,117,119,120$

labor NGOs, in China 129, 130-131, 133, 136; discussion 138-140; media negotiations 137-138; state negotiations 133-136; theory and methodology 131-133; workers negotiations 136-137

Laclau, E. 63

Lang, S. 59, 64

Larsen, A. G. 60

Lawyer Committee for Human Rights see Human Rights First (HRF)

Lee, M. 16

legitimation $15,56-58$

Lenfant, F. 20

LGBTQIA+ networks 181

Li Di 133-136, 138-139

Lippman, W. 53

literacy programs, to overcome climate changes 30

live interviews 189-190

live streaming, of events 93

Löfgren, Isabel 4, 179

Loms community 110

Long, P. 62

Loran, Gabriela 191

Lovejoy, K. 74-75, 83, 146, 149, 150-151

low/incongruent fit alliances 14

Luqiu, Luwei Rose 4, 128

Lyam S. 187, 192, 194

Mackreath, H. 124

Maktoufi, R. 14

Marcelle, Cinthia 181, 189

Martin, P. Y. 172

mass audiences 59

mass media 81

maternal health 91, 97

McPhee, P. 34

McPherson, E. 50

media: advocacy 164; democratization 4, 169-170, 174; frames 51

media activism 4, 160; defined 162; in South Africa 160-178; studying through institutional ethnography 164-165

Media Monitoring Africa (MMA) 161-162, 164-165; activism as practice $167-168$; activist values 165-168; democratic values $168-170$; equality as goal 170-171; feminist implications 
of 162 ; feminist values $170-174$; Gender in the Media project 170; interpersonal identification 167 ; as media activist organization 166, 167; media democratization 169-170; organizational feminism 171-174; organizational identification 166-167; public interest media advocacy 170 ; Theory of Change 172, 173

media NGOs 160; activist values 165-168; democratic values 168-170; feminist values $170-174$

Meena comics/animations 91, 93, 95-96

Meet Bob narrative strategy 94, 95, 97, 100, 102

membership buttons 79

Meyer, C. 124

Migrant Protection Protocols (MPP) 51,57

Millennial survey 22

Millennium Development Goals (UN) 113

Miller, W. 56

Mitchell, R. C. 30

Mitigating Child Labor Risks in Cotton 113

MMA see Media Monitoring Africa (MMA)

mobile technology 33

Moreno, N. 61

Mouffe, C. 63

MPP see Migrant Protection Protocols (MPP)

Muddiman, A. 66

Muir-Cochrane, E. 56

multiple publics/audiences, addressing 84

multi-stakeholder collaboratives 12

Murrell, C. 60

Muslim Ban in 201752

Muthambi, Faith 169

mutual aid organizations 183, 194

NACGOND see National Coalition on Gas Flaring and Oil Spills in the Niger Delta (NACGOND)

narrative strategies 94, 95, 132; archetypes in Bangladeshi NGO animations 95-96; BRAC 91-93; two explainer animations 96-102

Nath, S. 92

National Coalition on Gas Flaring and Oil Spills in the Niger Delta (NACGOND) 11, 18-19, 22 national donation campaigns 76

National Labor Law 130

Nature Conservancy 15

Nature Conservancy 39

Nelson, P. 109

Netherlands: neoliberal policy turn in 76; NGO communication strategy in 3; social change NGOs in 73, 76-77

Netvizz tool 150

networking resource mobilization 38 , 39,42

new media 148

news: coverage 51; games 61; organizations, and human rights issues 49-50

newsletter subscriptions 79

NGO-business partnerships 3, 9-28; communication 15-17; considerations for success 13-14; in developing countries 21; fit 14-15; implications 21-24; non-western country 17-21; for social change 11-13

NGO journalism 3; audience engagement 58-60; critic role in 63-65; Human Rights Watch and refugee rights 55 ; legitimation changes 56-58; method/analysis 55-65; new media forms 60-63; normative theories of 52-54; refugee advocacy in US 54; refugee crisis 50-52

NGOs see non-governmental organizations (NGOs)

Niger Delta 18

Nigeria: environmental collaborations in 18-20; environmental sustainability in 3 ; oil spills in 11

Nijhof, A. 11

non-governmental organizations (NGOs) 1; and age of SNSs 145-146; audiovisual medium for 4; banning foreign funding in China 141; brand familiarity 14 ; communication strategy in the Netherlands 3; hybridization of roles of 63-65; in India 131; media partnerships 49-50; media strategies 60; normative theories of journalism 52-54, 53; occupying spaces in civil society 4; refugee advocacy role 54; transvestigender style of management 185; see also environmental nongovernment organizations (ENGOs); 
International NGOs (INGOs); media NGOs

Nonprofit Tech for Good 33

normative journalism 50, 52-54, 53, 56

Obama, Barrack 51, 63

O'Çonnor, A. 14, 24

O'Dwyer, B. 19

official websites 42

offline communication $80-81$

oil spills, in Nigeria 11

Oliver, John 57

one-way communication 79

online donations 34

online musealization, of trans

experiences 190

opinion polls 79

organizational feminism 171-174

organizational legitimacy 4, 146, 155, 156

organizational websites 33

O'Sullivan, N. 19

Oxfram Novib 76

Paris Agreement 32

Parker, B. 13

participatory democracy $52,53,53$, 54, 59

Partnering Initiatives, The (TPI) 12

partner-oriented strategy 16

paternalist frame 51

Peruzzo, Cicilia 187

Pew Research Report 60

philanthropy 14, 23

Philip Morris 15

Podcast 31, 39

political elites 60

Powers, M. 50, 52, 53, 56, 63, 65

prior corporate reputation 14

private funding 76

privatization, of social services 183

Process Overview narrative strategy 94, 95, 100, 102

Project on International Seasonal Agricultural Migration in Turkey 113 prominent NGO 24

propaganda model 65

Protect LGBT Asylum Seekers 57

PR see public relations (PR)

PSAs see Public Service Announcement (PSAs)

public awareness 3, 49

public communication traditions 52

public funding 76 public relations (PR) 2, 74-75

Public Service Announcement (PSAs) 153

QDA Miner 35

queer migration 163

queer value, for commercial gains 184

radical democracy 52, 53, 54

Ramadan Food Bags initiative 151

Rangan, K. 23

Rashid, S. F. 92

Raza, W. A. 92

readymade garments (RMG) sector 90

REBRACA (Brazilian Network of

Shelters) 186

reciprocal promotion 17

recreational programs 148

recurrent keywords 42

Red Cross 1

Reducing Legal and Institutional Gaps in Prevention of Child Labor in

Seasonal Agriculture Project 113

refugees: archives 62; crisis 50-52; settlement 50-51, 124

Refugees Renew America campaign 59

Remain in Mexico policy 51

representative liberalism 52-53, 53, 54,58

resource dependence 13

resource mobilization strategies 3;

climate change ENGOs as social

change agents 29-32; among climate

change ENGOs in US 31-33;

comprehensive financial management

32; discussions 39-42; findings

37-39; fundraising capabilities 32;

ICT-enabled 31, 33-34; literature review 31-34; research method 34-37; study objectives 31

Resource Partition Theory (RPT) 31

Right 2 Know (R2K) Campaign 169

RMG sector see readymade garments (RMG) sector

Rohwer, L. 16, 24

Roms community 110

Ross, K. 163

RPT see Resource Partition Theory (RPT)

RYOT 61

SABC see South African Broadcasting Corporations (SABC)

Saber, D. 62 
Sadagaat 146-147; information 151-153; offline mobilization 154; reaching out to stakeholders 153-154

Sagnic, S. G. 124

Sainsbury 16

Sainsbury-Comic Relief 24

Sangar, E. 124

Sankofa, Matuzza 186, 190, 193

São Paulo, Brazil 179

Saxton, G. D. 34, 35, 74-75, 83, 146, $149,150-151$

Scacco, J. M. 66

SDGs see sustainable development goals (SDGs)

seasonal labor migration $110,117,119$, 120

self-promotion 16

Selsky, J. W. 13

Seo, H. 83

Serre-Delcor, N. 61

Shasthya Sebika (BRAC) 92

Shell 11

Shell-NACGOND partnership 18-19, 22

Shumate, M. 14, 16, 24

Sichuan earthquake (2008) 128

Sikkink, K. 49, 53, 63

SIMSTAT program 35

Sinem Sefa Bayraktar 115-123

Smith, D. E. 164-165

SNSs see social networking sites (SNSs)

social alliances see NGO-business

partnerships

social assistance 183

social change competencies 11,12

social inequalities 54

social issues 13,49

social legitimacy 15-16

social marginalization 160

social media $2,16,33,93$; as

aggregator for trans communities

187 ; as participatory media 83 ;

resource mobilization strategies 34

social media, in NGO strategic

communication 2, 73-89;

addressing multiple publics/

audiences 84; advertising 82;

different communication goals

82-83; Dutch NGO sector 76-77;

ecosystem approach 75-76,

85; fashions and trends 83-84;

mapping communication ecosystems

79-84; mass media coverage

81; methodology 77-78; offline communication 80-81; public

relations (PR) approach $74-75$

social networking sites (SNSs) 145-146, 149

social partnerships 11-12

social turn 184

societal sector platform 13

Sogge, D. 109

solitary NGO 24

Sorce, Giuliana 1, 4, 160

South African Broadcasting

Corporations (SABC) 161, 166-169

South Africa, NGO media activism in 160-178

South America 50

South Asian Association for Regional

Cooperation 90

South Sudan, secession of 147

Spade, Dean 180, 183, 194

stakeholder dialogue 18-19

stakeholder engagement 148

stewardship 12

Stitching BRAC International 92

storytelling 95, 132

Stroud, N. J. 66

Sudan: Internet and SNSs 146; issue mobilization 3; NGOs 145-146;

social change advocacy 4

Sudanese National Blood Bank 153

Sunflower Movement in Taiwan 141

Sung, Y. 16

sustainability $9,24 n 1,112-113$

sustainable development goals (SDGs) 10,17

Symbiotic Sustainability Model 14

symmetric communication 148-149

Syrian Civil War 50

Syrian Dom (refugee community) 4, 110

Tarrow, S. 63

Taylor, M. 149

TAZ see temporary autonomous zones (TAZ)

technological resource mobilization 38 , 39,43

temporary autonomous zones (TAZ) 182

text-mining approach 3, 31, 35-37

text solicitations 38

textual contents, of ENGOs 37

TF-IDF (term frequency-inverse document frequency) 37

Topić, M. 16, 24 
TPI see Partnering Initiatives, The (TPI)

trans care 179 ; as artisticactivist practice of 183-184; as communicative practice 186-188

trans individuals 179, 184-185

transparency, in NGOs communication 4, 147

trans re-existence 193

transvestigender $194 n 1$; and Casa Chama in Brazil 4, 179-193; style of NGO management 185

Trump, Donald 51, 58, 63

trust 22-23

TSOs (Third sector organizations) 110

Turkey: advocacy 4, 110; digital participation initiatives 3; importance of NGOs in civil society 111-112; Syrian migrants arrival 111-112, 116-117; see also Development Workshop Cooperative (DWC)

Twitter 16, 34, 40, 81, 84, 145, 149

Twombly, E. C. 32

two-way communication 79, 84, 149

Umbrella Movement in Hong Kong 141

UN see United Nations (UN)

UNFCCC see United Nations Framework Convention on Climate Change (UNFCCC)

UNICEF 90; Meena comics/animations 91, 93, 95-96; Program Cooperation Agreement 114; Program on Elimination of Child Labor 114; sustainability plan 92

United Nations (UN): Millennium Development Goals 113; Sustainable Development Summit 113; World Meteorological Organization 66-67

United Nations Framework Convention on Climate Change (UNFCCC) 43

United Nations High Commission for Refugees Global Trends Report 51

United States (US): ENGOs in 3, 31; foreign and immigration policy 52; Muslim Ban in 2017 52; refugee or asylum status in 50-52; resisting regulations on greenhouse gas emissions 9

University City sanitation workers' strike, Guangzhou 136
UN Women 90

Upworthy 61-62, 66

US see United States (US)

USCAP see US Climate Action

Partnership (USCAP)

US Climate Action Partnership

(USCAP) 9

value-creation 21

Van Huijstee, M. 18

van Tuijul, P. 112

Van Wassenhove, L. N. 62

van Zyl, J. 161

virtual reality videos 61,64

visual infographics 37

visualizations 94

Vu, H. T. 83

Vulture Club 60

Waddell, S. 11

Waddock, S. A. 11-12

Wadham, H. 21

Warren, R. 21

Waters, R. D. 93

Web 2.0 technologies 148

Westersund, E. 56

WhatsApp 156, 188

Whitehead, D. 21

women: media action model 163 ;

missing involvement in news media 162; social status in South Asia 90; symbolic visibility for 164

Women's Legal Studies Center 129

WordStat program 35

World Hepatitis Alliance (China) 135

World Meteorological Organization 66-67

World Women's Conference in Beijing 128

Wylie, L. 61

Xi Jinping 129

Yagoub, Anwar Ibrahim 147

Yang, Kenneth C.C. 3, 29, 34

Yianni, M. 13

zero-tolerance policy 51, 58

Zhang, Y. 16

Zuma, Jacob 169 


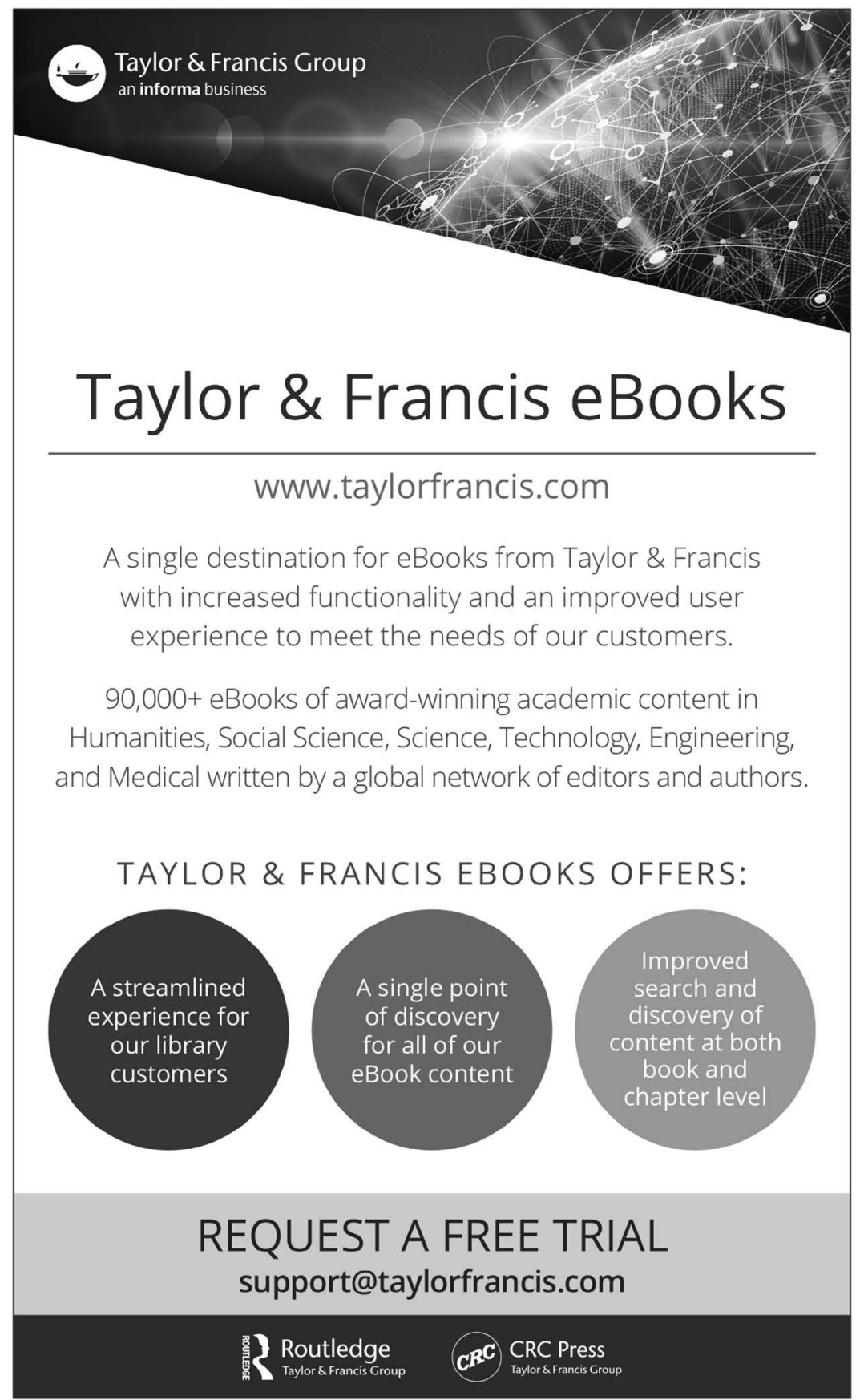

